\title{
التشخيص التنظيمى للمدارس الثانوية العامة في ضوء نموذج ويسبورد للصناديق الست Six-Box Model دراسة ميدانية على محافظة الشرقية \\ weng /
}

استاذ التربية المقارنة والإدارة التعليمية المساعد

كلية التربية جامعة الزققازيق

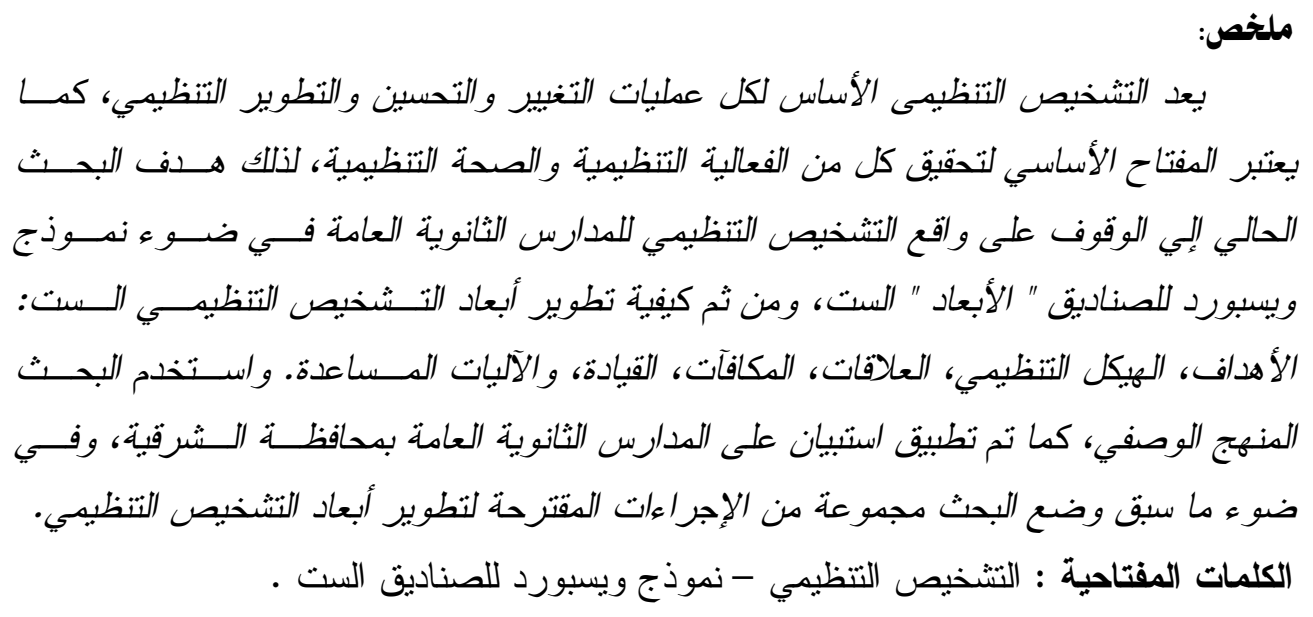

Organizational Diagnosis of General Secondary Schools in the Light of the Weisbord's Six-Box Model-Field Study on Sharkia Governorate

\section{Abstract:}

Organizational Diagnosis is the basis for all processes of change, improvement and organizational development. It is the basic key to achieve both Organizational Effectiveness and Organizational Health. Therefore, the current research aims at identifying the reality of the organizational diagnosis of secondary schools in light of Weisbord's Six Box Model, andhence how to develop the dimensions of the six organizational diagnosis: Objectives, organizational structure, Relationships, Rewards, Leadership, and assistive mechanisms. The Researchused the DescriptiveMethodology, and then applied a questionnaire to the General Secondary Schools in Sharkia Governorate. In light of the above, a Researh Presented some of proposedProcedures to develop the dimensions of Organizational Diagnosis .

Keywards : Organizational Diagnosis - Weisbord's Six Box Model . 


\section{مقدمة :}

وينظر إلى التشخيص التنظيمى علـى

أنه اســتر اتيجية تـستخدم لتحسـين الأداء

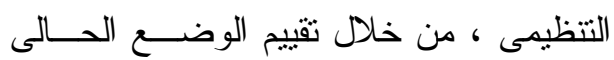

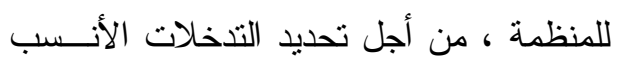

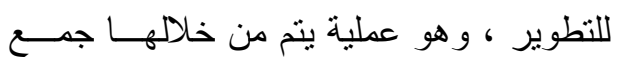

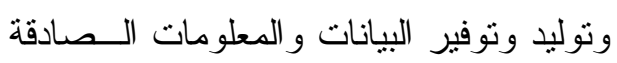

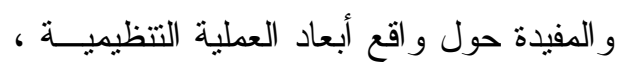

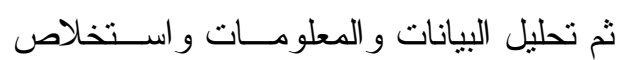

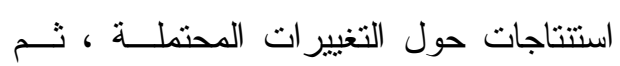
اتخاذ الإجر اءات و التدابير الصحيحة. ومن ثم يتضح أن أية مبادرة للتغييــر

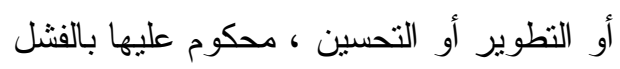

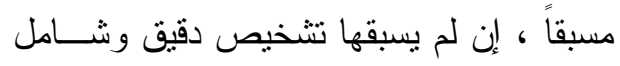

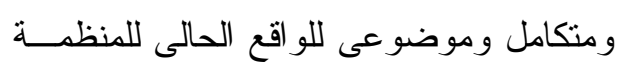

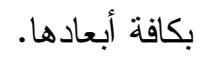

كما ينظر إلى التـشخيص التنظيهـى

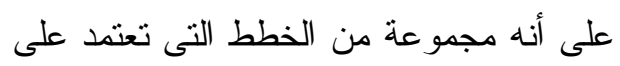

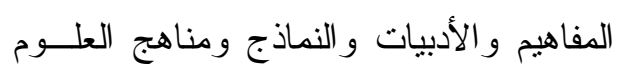

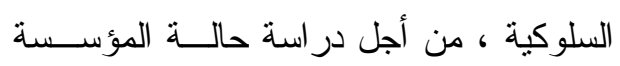

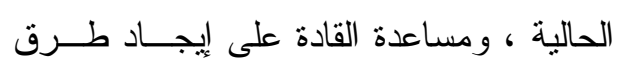

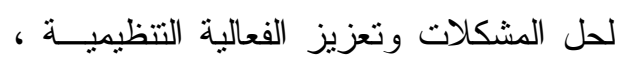
وهو أكبر من مجرد اســتخدام جيــــ لأدوات

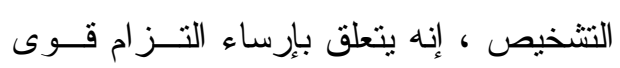

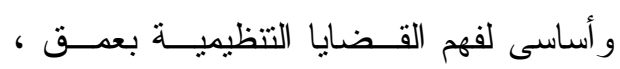
ومماسة التحقق التتظيمى الصارم و الحاسم •

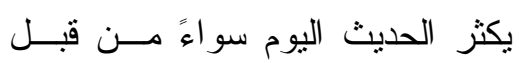

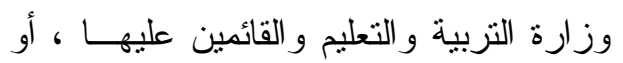
من قبل كافة المرتمين بالثأن التعليمسى فـي ولئي

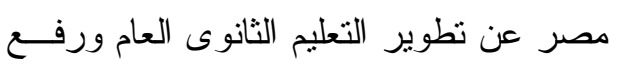

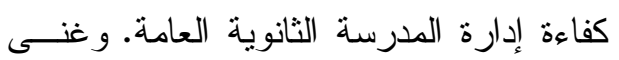

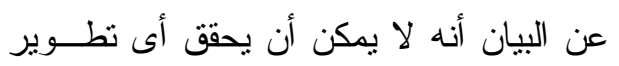

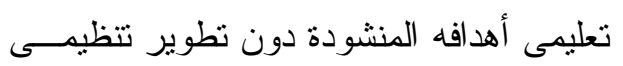

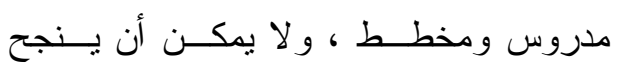

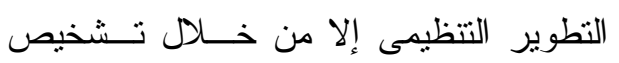
تتظيمى دقيق وشامل وموضوعى لكافة أبعاد

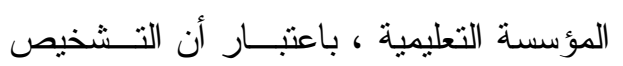

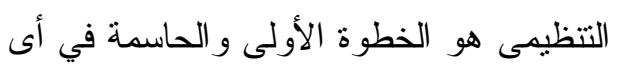
تغيير أو تطوير نتظيمى منشود. إن أية مبادرة أو استر اتيجية للتغييــر لتفرد

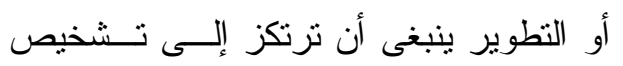

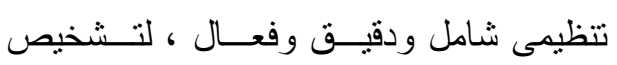

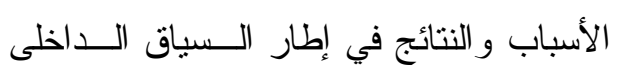

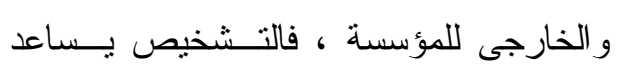

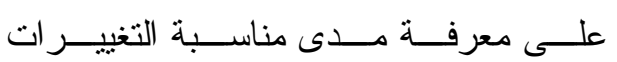

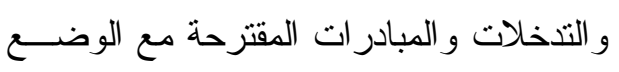

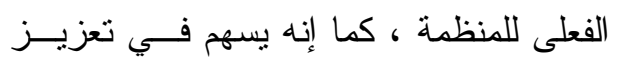

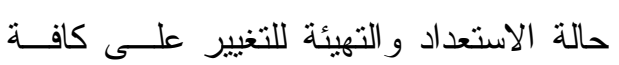

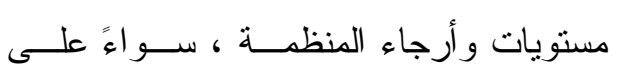

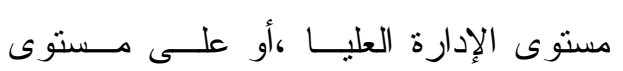

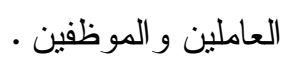


- يعد المفتاح الأساسى لكيفيـة اســتجابة

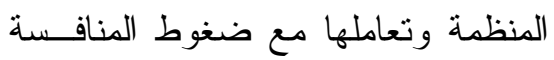

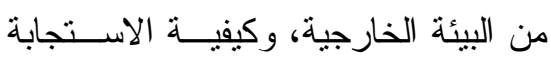
للتغيير ، كما يوفر الأساس السليم لاتخاذ

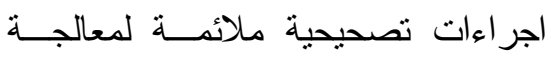

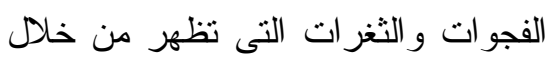
التقييم و النتخيص الدقيق .

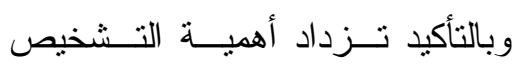

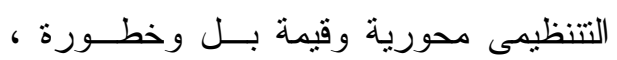

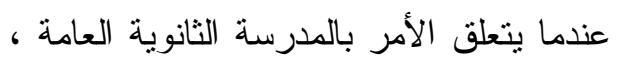
و التى تمنل تتظيماً مفتوحاً ومعقداً ، ويتعامل

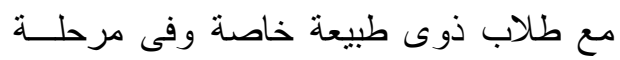

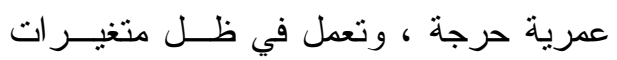

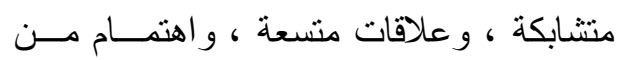

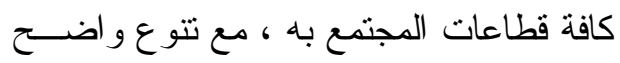

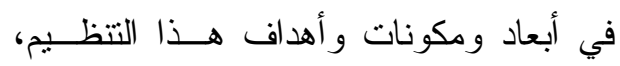

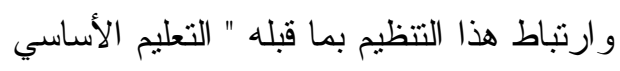
" و ارتباطه بما بعده " التعليم الجامعي " .

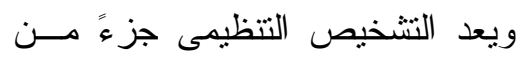

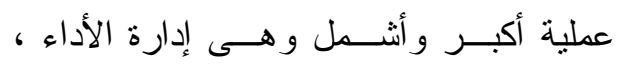

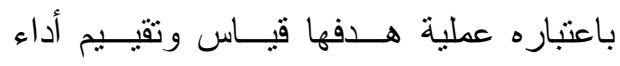
المنظمة .كما بعد التـشخيص التتظيمـى أداة

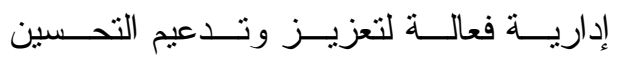
و التطوير والتغيير التتظيمى من أجل استدامة المنافسة . والطوير و و التشخيص التنظيمى لا بيسمح فقــ

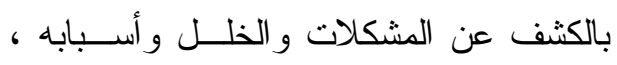

و اعتبر البعض التشخيص التتظيمسى منهجاً أو أداة بحثية علمية تدور حول الوقوف لفض على تقييم دقيق لوضع المنظمة ككل أو لجزء

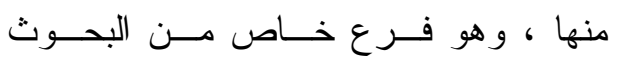
و المجالات التتظيمية التى تؤدى إلى مجموعة ون من الأبعاد حول خيار ات التخطيط و التصميم و الاستعداد للتغيير الادهاد هون

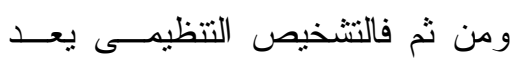

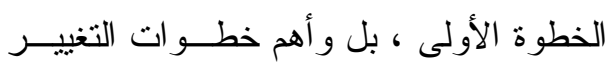

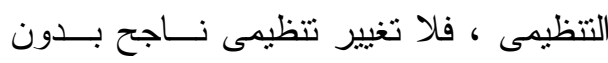
تشخيص نتظيمى دقيق. ويمكن بلورة أهمية التشخيص التنظيمى من نئن

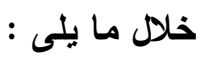

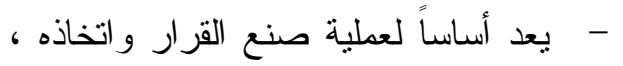

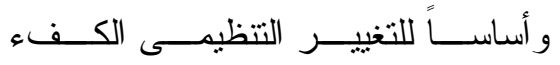
و المستتير ، كما يستخدم كأساس في تقييم

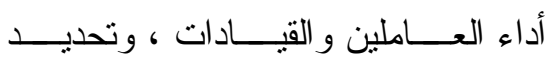
احتياجاتهم التدريبية .

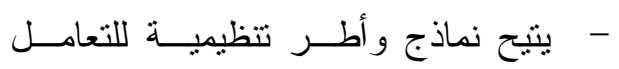

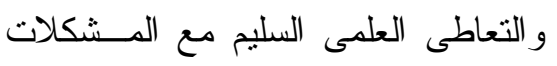

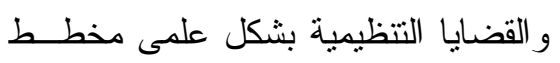
ومنظم ، بالاعتماد على نظريات العلــوم السلوكية ، حيث تساعد هذه النماذج فــي لئي

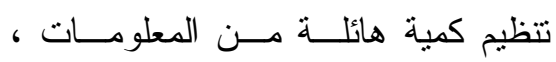

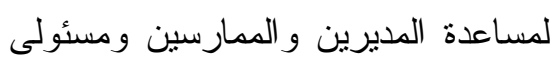

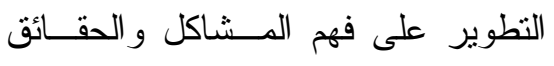
التتظيمية . 
النموذج لإجر اء التشخيص التنظيمى ، كونــهـ يبين للممارسين أين ينظرون ، وفيم ينظرون

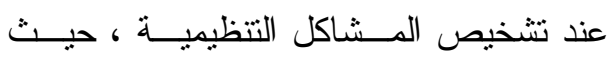

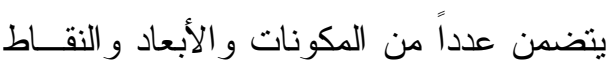
التتظيمية ، و التى قد تكون فى حالة جيــدة أو الو

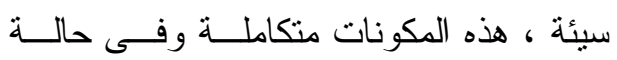

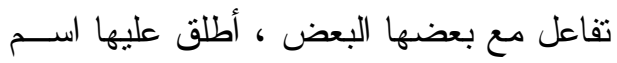
الصناديق الستة .

و اقترح ويسبورد 1977 ستة أبعاد أو

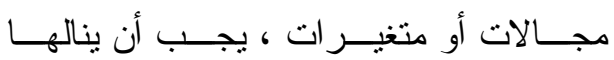

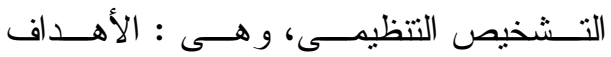

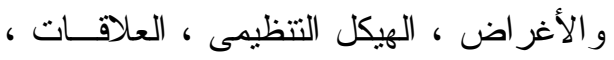

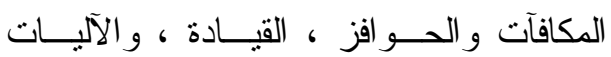
المساعدة أو المساندة .

ونموذج ويسبورد بركز على القضايا

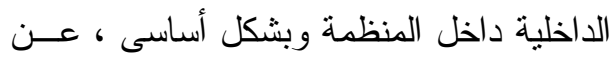
طريق طرح أسئلة نتخيصية حددها فى : ما

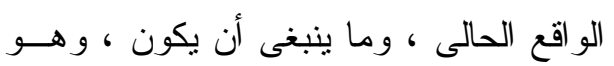

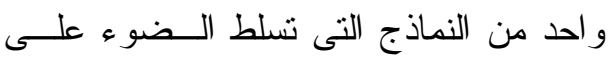

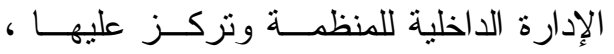

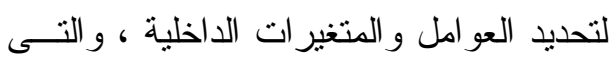
يجب وضعها فى الحسبان لتكييف ممارســات

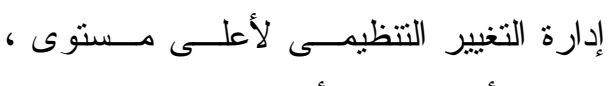
وتحقيق أداء نتظيمى أكثر فعالية .

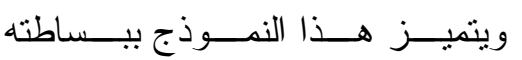

ووضوحه ، وتعدد متغير اته و أبعاده وتباينهــا

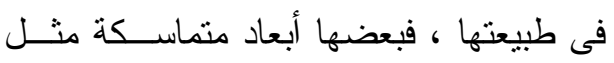

و إنما يساعد على اعداد الأفراد - مديرين أو معلمين أو عاملين - للتغييرات و التحــــاتلات الضرورية ، كما تساعد نتائجسـه المــديرين

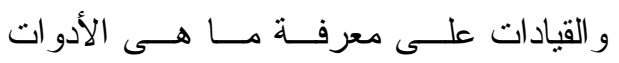
و الآليات الأفضل لزيادة فعالية تتفيذ التغييرات

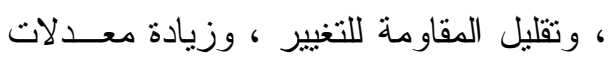

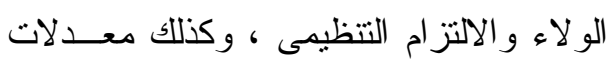

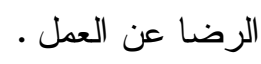

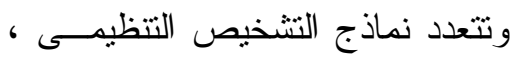

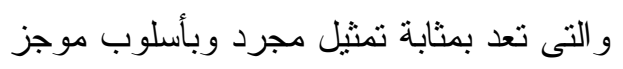

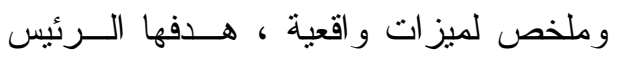
تنبسط الو اقع للمتعاملين مع المنظمة ، و الذين

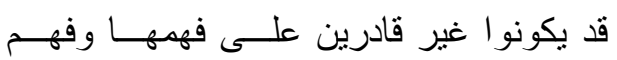

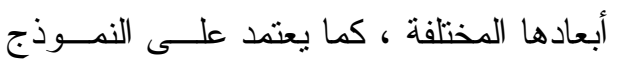

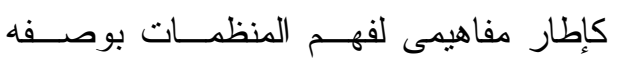
للعلاقات بين المتغير ات التتظيمية .

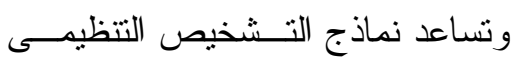

على تحديد وفهم المتغير ات والأبعاد التنظيمية

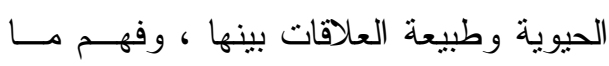
يحدث في المنظمة بسرعة ووضوح ، ، إضافة

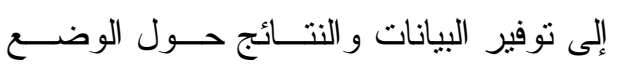
الر اهن للمنظمة . لوديز

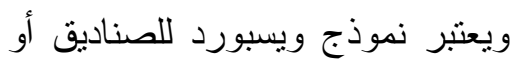

الأبعاد الست Six-Box للتشخيص التنظيمى وئير ، من أهم نماذج النشخيص التتظيمى وأكثرها شهرة واستخداماً ، ووفقاً لإحدى الدر اســات التهات

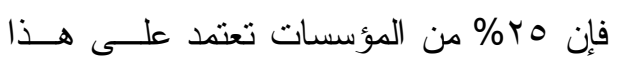


الإصلاح المتمركز حول المدرسة ، وبرنامج

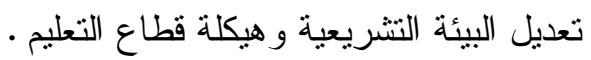
كما كان الهيكــل التتظيمــى بأبعــاده

الفرعية أحد المحاور و المجــالات الأساســية بابعاده للقدرة المؤسسية ، ضمن معايير ومؤشــرات الات

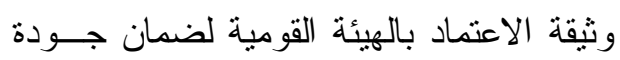
التعليم و الاعتماد .

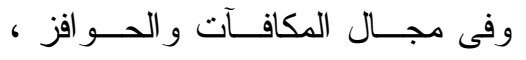

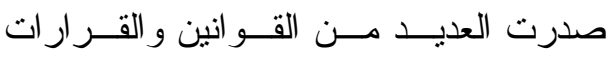

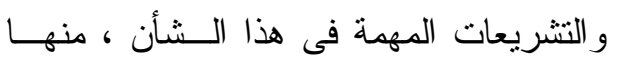

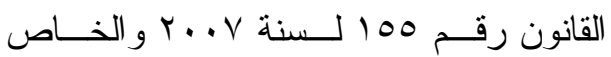
بكادر المعلمين و الوظائف التعليمية الأخــرى

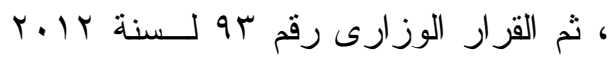

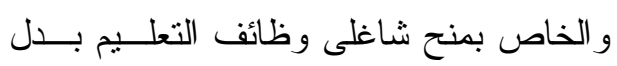
معلم وقدره .0\% من الأجر الأساسى .

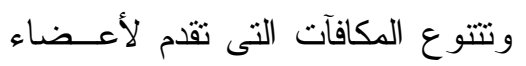
هيئة التعليم ، سواءً كانت مكافآت عن جهود غير عادية ، مكافآت نشجيعية مقابل خدمات

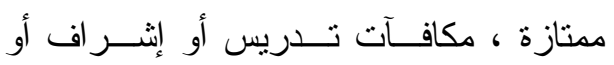

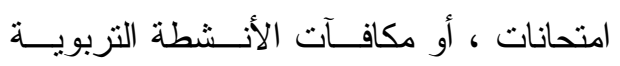

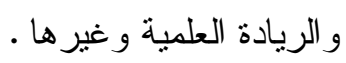

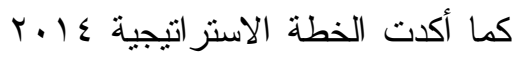
- . - . . على بناء منظومة للمتابعة و التقويم

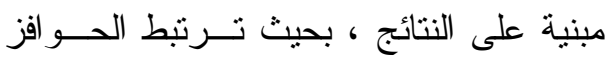

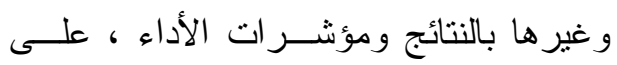

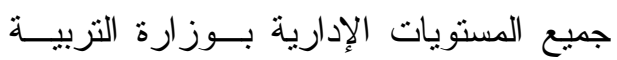

الأهداف و الهيكل التنظيمى ، وبعضها مــرن منل القيادة ، العلاقات ، و المكافآت ، كما أنها

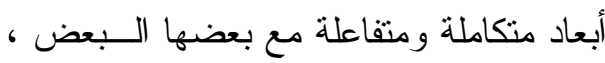

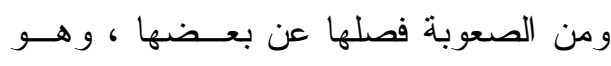
نموذج لا يحتاج إلى وقت كبير فــى عمليـــة

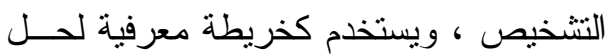
مشكلات التتظيم ، كما إن وجود ستة أبعـاد

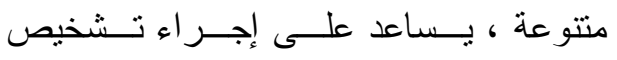

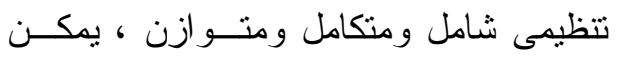

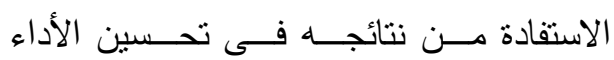
التنظيمى وتحقيق الفعالية و الصحة التنظيمية. وقد بذلت مصر العديد مــن الجهـــود

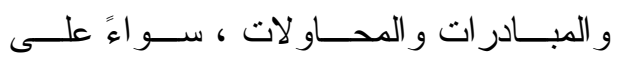

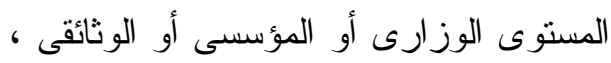

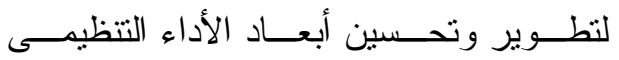
بالمدرسة الثانوية العامة.

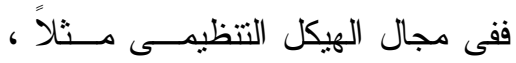
كان أحد برامج الخطة الاستر اتيجية للتعلــيم

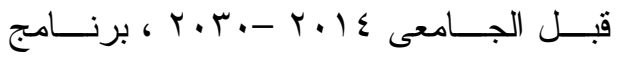
تطوير البنية المؤسسية لمنظومة قطاع التعليم

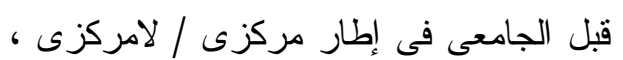

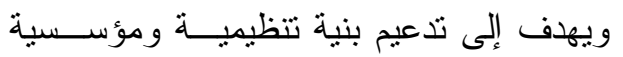
توازن بين صلاحيات الجهاز المركزى لقطاع التعليم قبل الجامعى ، وبين تدعيم صلاحيات مالية وإدارية للمدارس ، ويندرج تحت هـــا البرنامج عدة بر امج فرعية مثــل ، برنـــامج

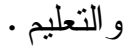


التحويلية ، مهار ات القيادة التعليمية فى إدارة

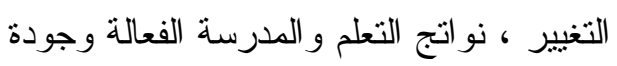
• التعليم

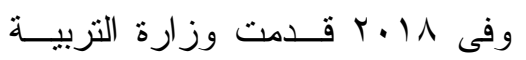

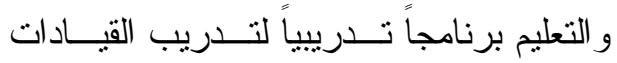
العليا و الوسطى بمديريات التزبيـــة و التعلـــيم

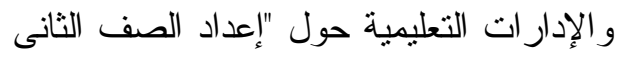

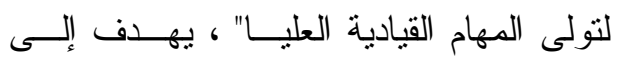
اكساب المشاركين المهار ات الجديدة لــلإدارة

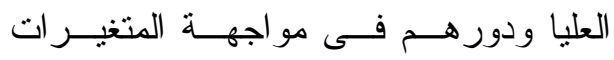
و التحديات المعاصرة . مشكلة البحث : على الرغم من الجهود و المبــادرات المــصرية المبذولــة لتحسـين أبعـاد الأداء التتظيمى بالمدرسة الثانوية العامة ، إلا أنـــه

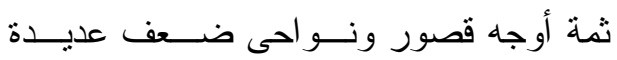
ومتتوعة فى هذا الثأن ، وذلك على النحــو التالى :

$$
\text { ا-الأهد (ف) : }
$$

من أهم نقـــاط الــضعف وأوجــهـ القــصور ما يلى : مانى

1-1-الافتقار إلى رؤية تربويــة و اضــحة

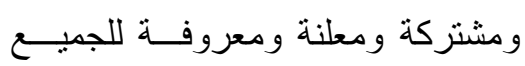
ومرنكزة على الطالب باعنباره محور ومعرد العملية التزبوية .
وفى مجال القيادة ، كــان مــن أهـــ

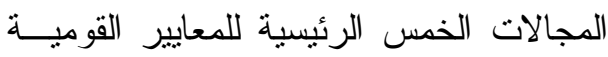

للتعليم فـى مـصر r... r ، مجــال الإدارة

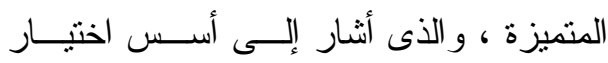

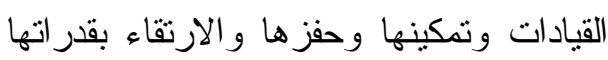

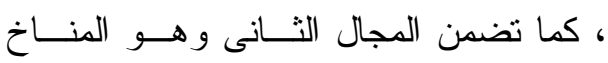

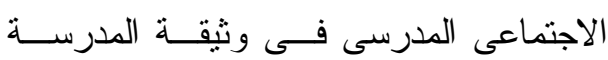
الفعالة عدة معايير ، كان من أهمهـــا قيــادة فئه

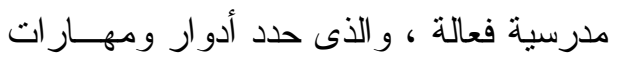
وكفايات القيادة المدرسية الفعالة .

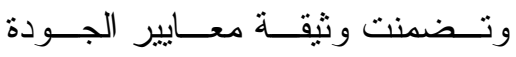

و الاعتماد بالهيئة القومية لضمان جودة التعليم و الاعتماد عدة مجالات ومعايير ، كان مسن جـن

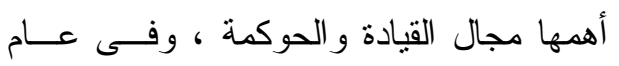

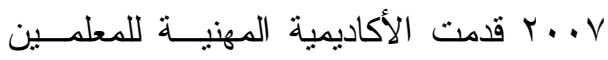
برنامج المجتمعات المهنيــة للــتعلم لتتميــة القيادات المدرسية. وقامت وز ارة التزبية و التعليم بإعــداد

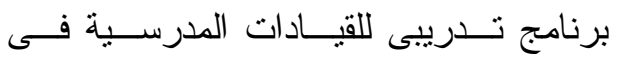

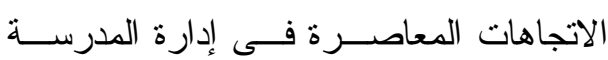
الثانوية ، تكون من خمس مديو لات تـــنبط بالاتجاهات المعاصرة ومهارات المــديرين،

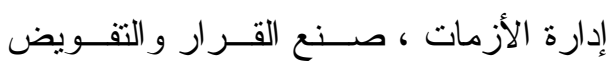

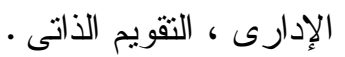

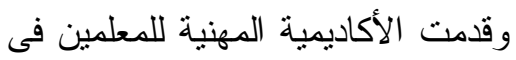

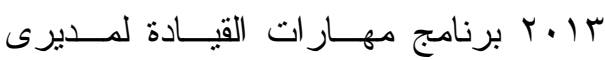
المدارس ، مشتملاً على أنماط القيادة ، القيادة 
المدرسية فى نشر ثقافــة اللامركزيـــة وتفعيلها داخل المدرسة .

ץ-r- ترهل الهيكل التتظيمـى وتــخهـ

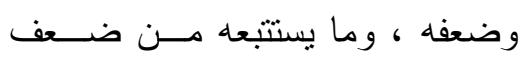

مستوى اســتقر اءه ، بــسبب انتهـشـار

الـــسلوكيات المرضــــية و الــــروثين

و الرشوة و المحسوبية ، وتزكز الهيكل

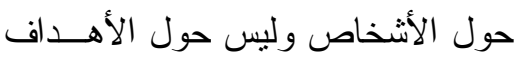

$$
\text { و الوظائف . }
$$

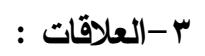

من أهم نقــاط الــضعف وأوجـــه القــصور

\section{ما يلى:}

r-1- ضعف العلاقات الإنسانية السليمة التى

تزبط المديرين بالعاملين معهــم فـى

المدارس ، و انخفاض الروح المعنوية

و الثقة بين القيادة و العاملين •

r-ץ- ضعف التعاون بين الوحدات المتتوعة

الموجودة بالمدرسة الثانوية من أجــل

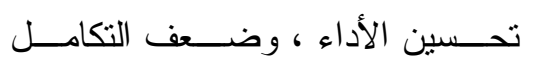

و التتسيق بينها ، حيث تعمــل وكأنهـــا

$$
\text { جزر منعزلة داخل المدرسة . }
$$

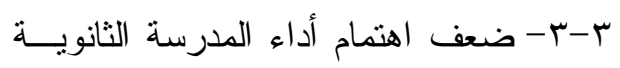
بايجاد مناخ إيجابى يشجع على التعليم و التعلم ، ويشجع على نمو العلاقـات الإنـــسانية داخـــل المدرســـــة ، لأن المديرين يضعون العلاقات الإنــسانية فى مرتبة متــأخرة مسـن اهتمامسـاتهم ا-r-r-إدارة المدرسة الثانوية لا تولى اهتماماً

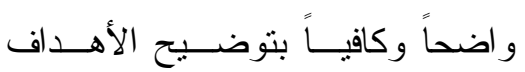

الاستر اتيجية للمدرسة .

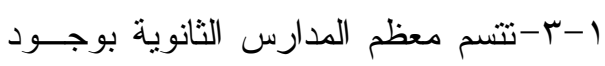

درجة مــن الــضـف فــى مــشاركة

العاملين و المعلمين في صياغة رؤيـــة

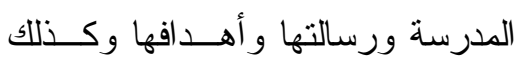

ضعف التوافق حول الرؤية و الأهداف ولف ولف

$$
\text { r- الكهيكل التنظيمى : }
$$

من أهم نقـــاط الــضعف وأوجـــه القــصور ما يلى

ץ-1 ضعف كفاءة البنى والهياكل التتظيمية لأجهزة التعليم ، و غياب إعادة الهيكلة، إضافة إلى ضعف تطبيــق سياســات المركزية و اللامركزية ، وضعف نظم الاتصالات و المعلومات ودعم اتخــاذ

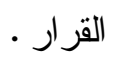
r-Y سيادة ثقافة المركزية علـى مـستوى

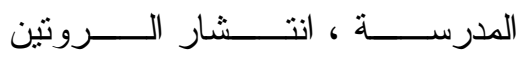

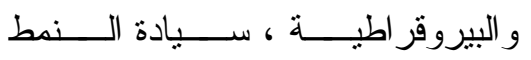
الأوتــــوقر اطـى فـــى إدارة المدرســــة الثانوية ، ميل عدد كبير من قيــادات المدارس الثانوية إلى النظم التقليدية فى مئي سير العمل ، بل ومقــاومتهم للتغييــر و التطوير ، إضـافة إلى إخفــاق الإدارة 


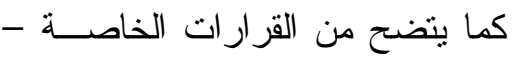

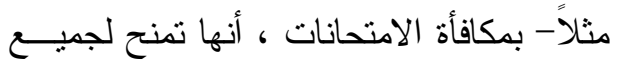

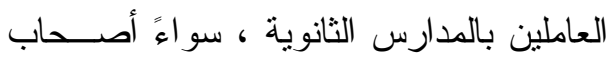

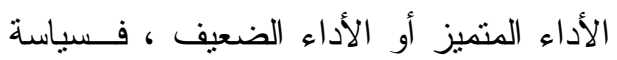
الحو افز فى مصر لا تميز بين المجتهد وغير لاهدير

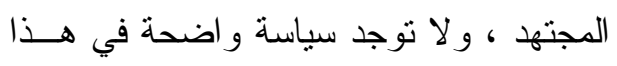

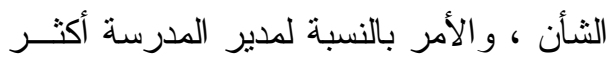

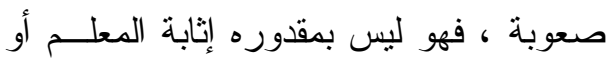

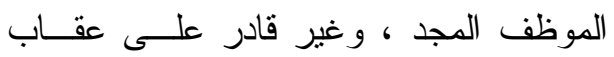

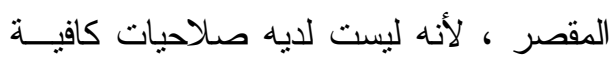
في هذا الثنأن • ه-القيادة : من أهم نقـــاط الــضعف وأوجــهـ القــصور

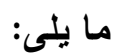
0-1 - فقدان الممارسات القيادية لاحتر افيــة التعامل الإدارى ومقترحات النطور الـــواردة من العاملين و المعلمــين ، ونــــرة إعطــــاء أولويات التقويض الإدارى ، مما ينعكس سلباً

$$
\text { حيال إعداد الكو ادر القيادية الجديدة . }
$$

-r-ب- ضعف تحديد وقياس فجــوات الأداء

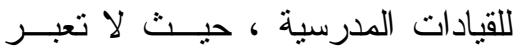

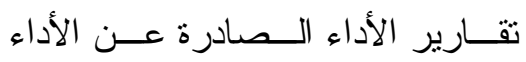

$$
\text { الفعلى للقيادات . }
$$

0-ب- ضعف امتلالك كثيــر مــن القبــادات المدرسية للمهار ات اللازمة لمواكبــة التغير المعرفى و التكنولوجى ، و القدرة على ترسيخ قيم التميز •
و أولويــاتهم ، إذ تكــــــن اهتمامــاتهم منصبة - فى الغالب - علــى العمــل وفقط.

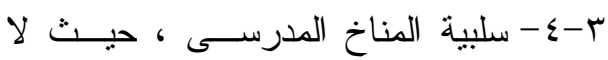
تسود قـيم العهـلـل الجمــاعى وروح الفريق و الرؤية المشتركة ، مع ضعف لهف الاتصسال المفتوح بين الأطر اف المعنية

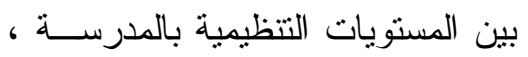
بما يعوق تدفق المعلومات و الخبـــرات

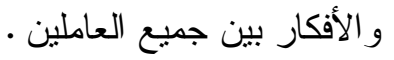
ع -المكافآت والحوافز :

أكدت إحدى الارسات على وجود العديد من

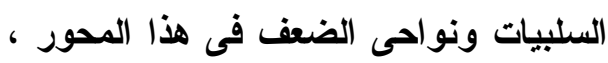
- قلة فرص منح الحو افز المادية والأدبية. - قلة الفرص المتاحة لترقية المعلمين.

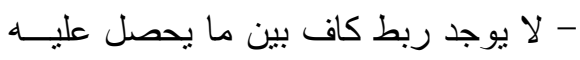

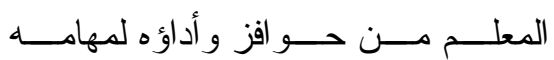

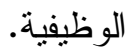

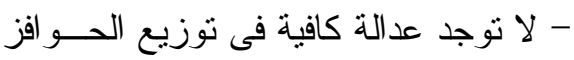
على المعلمين. - لا ينم تحفيز المعلمين بناءً على سياسات لعات

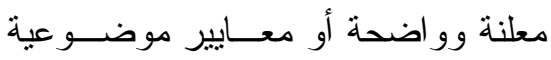

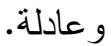
- فى كثير من الأحيان لا يتم تقديم الحو افز بصورة دورية ومستمرة. 
؟-ب- عدم إعطاء اهتمام للقاءات الحواريـــة

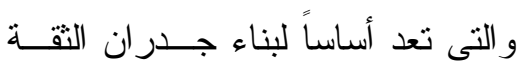
التتظيمية ، روتينية وسائل ووسـائط لتعاء

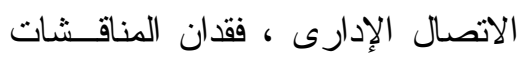

و الحو ارات للــشفافية الإداريـــة، قلــــة

استخدام أساليب الاتصالات المتبادلـــة

مثل نظم الاقتراحات ولوحة الإعلانات

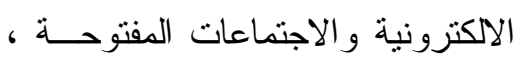

وندرة الـــدعم الإدارى ماديــاً وماليــاً لكأفكار الإبداعية .

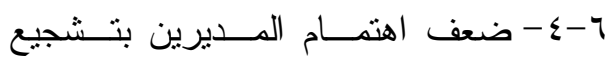

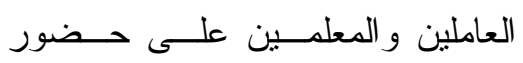

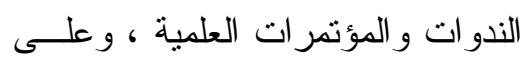

البحث عن فــرص جديــدة للتتميــة وعنة

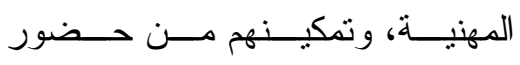

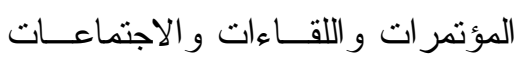

التربوية و المشاركة في الزيار ات ذات

العلاقة بالعملية التعليمية .

الجدير بالذكر أن الاستر اتيجية الجديدة

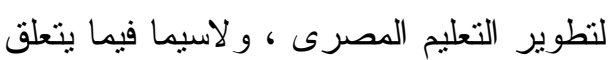

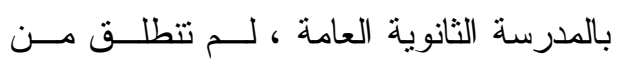

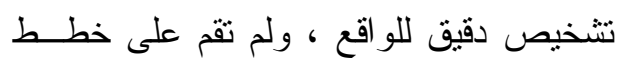

و أبحاث مدروسة ، وتتم عن عشو ائية القرار

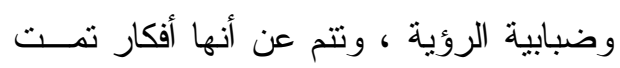

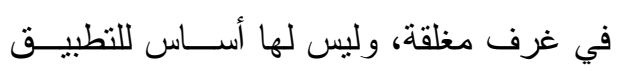

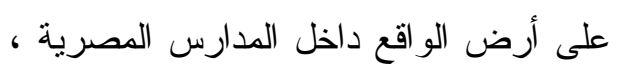

ه-ــ لاز ال أســـلـوب اختيــــــار القيــــادات

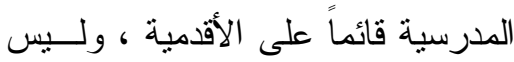

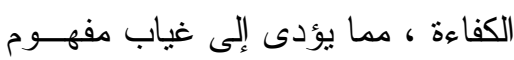

القيادة التعليمية .

0-0-وجود عدد كبير من المــديرين غيــر

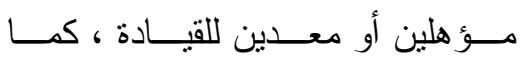

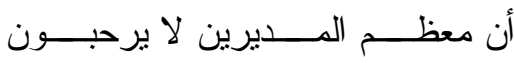

بالتغيير ات الجذرية ذات الفو ائد الكبيرة

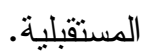

צ-الآليات المساعدة :

من أهم نقـــاط الــضعف وأوجــهـ القــصور ما يلى :

1-1 - ضعف اعتماد إدارة المدرسة الثانوية

على تكنولوجيا الاتصالات و المعلومات

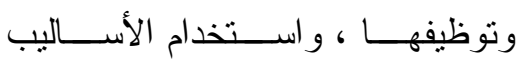

الثقليدية في إدارة المدرسة .

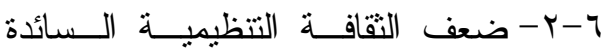

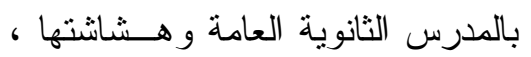

ومظاهر ذلك كثيرة منهــا : ضــــف وهن

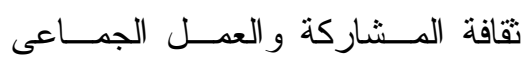

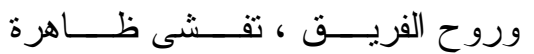

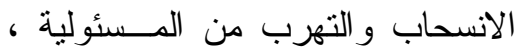

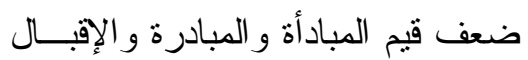

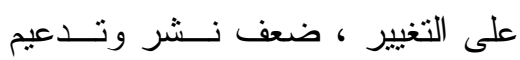

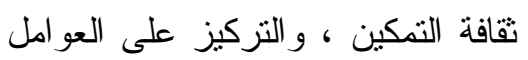

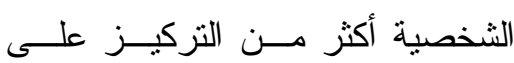


الخـــصائص ، الأنـــــاع ، المر احــل ،

$$
\text { المنطلبات ومعوقات تطبيقه؟ }
$$

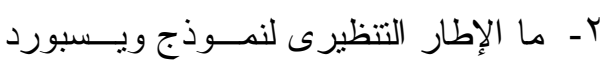

للصناديق الست للتشخيص التتظيمى؟

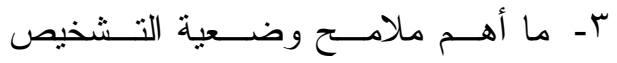

التنظيمى للمدارس الثانوية العامة بمصر ماهر

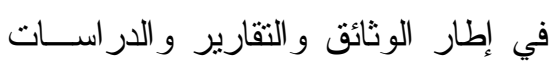

السابقة وفق نموذج ويسبورد؟

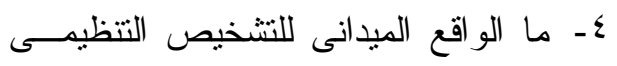

للمدارس الثانوية العامة بمحافظة الثرقية

$$
\text { وفق نموذج ويسبورد؟ }
$$

ــ ـ ما الإجر اءات المقترحة لتطــوير أبعــاد

التتخيص التتظيمى بالمدارس الثانويسـة

العامة في ضوء نموذج ويسبورد؟ أهداف البحث :

يتمنل الهدف الرئيس للبحث الحالى في

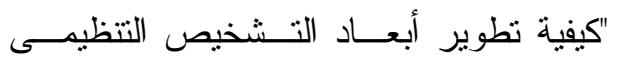

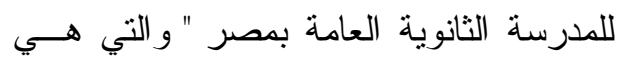

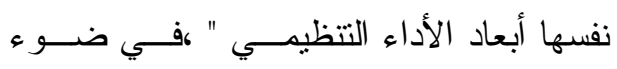

نموذج ويسبورد للنتخيص التتظيمى".

ولتحقيق هذا الهرف الرئيس ، يلزم تحقيـق

$$
\text { الأهداف الفرعية التالية : }
$$

1- التعرف على الإطار التنظيرى المفاهيمى : التهى

$$
\text { للتشخيص التتظيمى. }
$$

r- الوقوف على طبيعــة وملامــح نمـــوذج

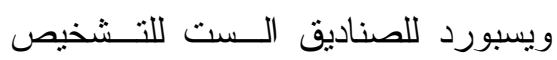

ولا توجد رؤية و اضحة لحل مشاكل التعلــيم

حتى الآن .

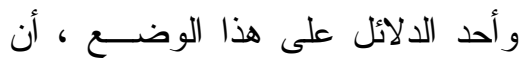

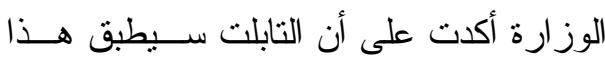

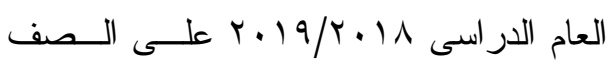

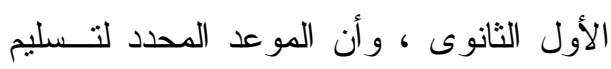

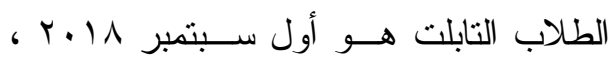

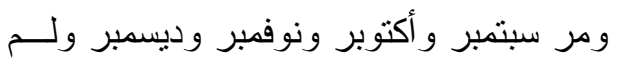

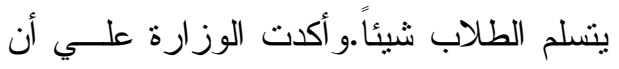

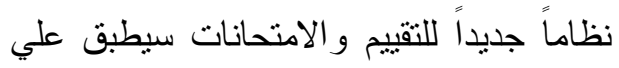
طلاب الصف الأول الثانوي ، و انتهي الفصل الدر اسي الأول ولم بطبق شئ سوي الامتحان

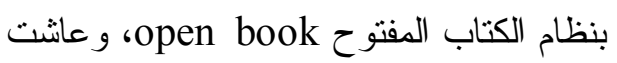
العملية التعليمبة و الطلاب في حالة من التخبط

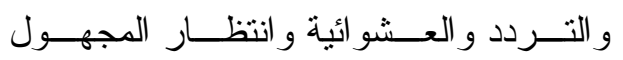

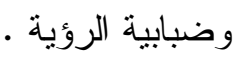

وفى ضوء ما سبق ، يمكن بلــورة مــشكلة

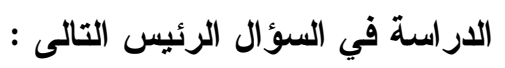

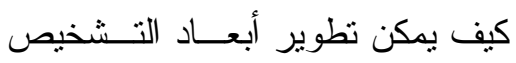

التتظيمى بالمدرسة الثانوية العامة بمصر في بعري

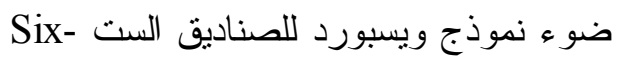
@Box Model ويتفرع من هـــا الــسؤال الـــئيس الأسئلة الفرعية التالية : 1 - ما الإطار التتظيرى للتشخيص التتظيمى،

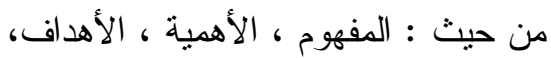


و الأبعاد التظظيمية الداخليــة للمنظمــة ،

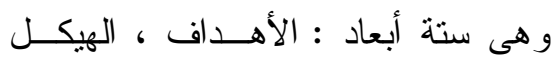

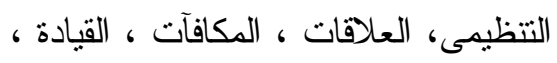

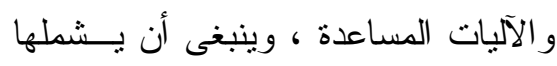
التـشخيص ليكــون تشخيــصاً شـــاملاً ومتكاملاً ودقيقاً ، وقد أكدت الدر اســات

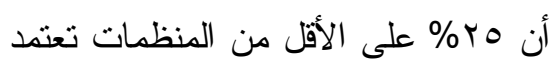

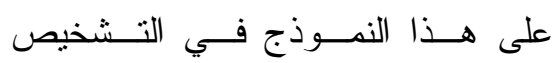
التتظيمى.

r- تأتى أهمية هذا البحث كمساهمة علميـــة

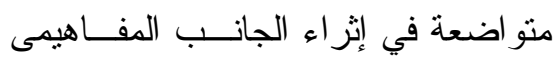
التتظيرى في مجال السلوك التتظيمسى ،

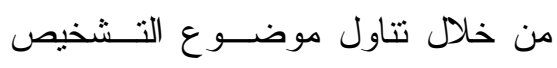
التتظيمى وفق نموذج ويسبورد.

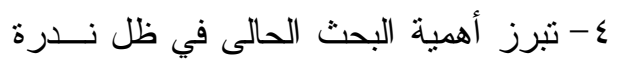

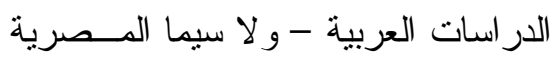
منها - التى نتاولت أو اهتمت بموضوع

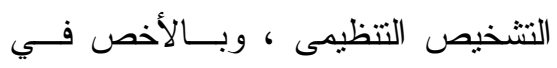
المدارس الثانوية العامة.

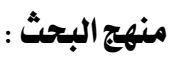
اتبع البحث الحالى المــنهج الوصــفى

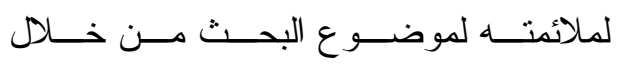
الاجر اءات التالية :

- دراسة وصــفية للتـشخيص التتظيهـي

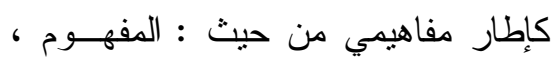

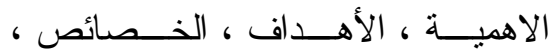

ب-رصد أهم ملامح وضــعية التـشخيص

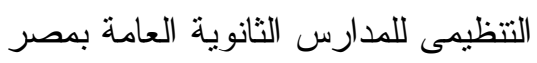

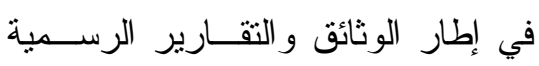
و البحوث و الدر اسات السابقة. ع- رصد وتحليل و اقع التشخيص التنظيمسى ولى

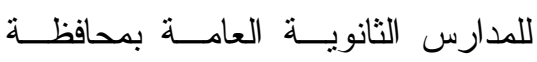
الثرقية ميدانياً. ه- التوصل إلى مجموعة مــن الإجـــر اءات

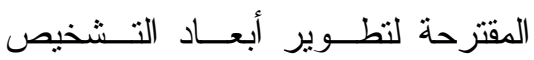
التتظيمى للمدارس الثانوية العامة بمصر لئر

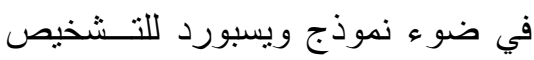
التظظيمى. أهمية البحث : تتضح أهمية البحث الحالى من خلال النقاط التالية : 1- تتطلق أهمية البحث الحالى مــن أهميــة

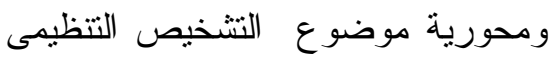

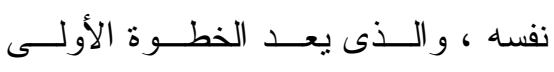

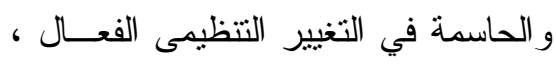

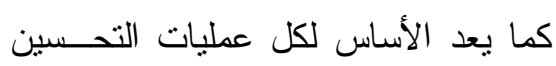

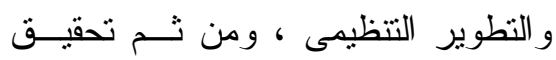
الفعالية و الصحة التتظيمية. r- تتطلق أهمية البحث الحالى مــن تتاولـــه

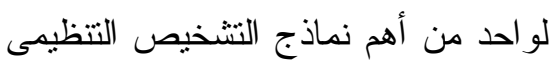
و أكثر ها شهرة، وهو نموذج وئسيسورج

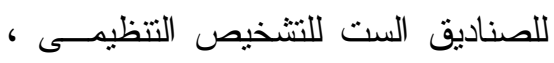
و الذى يركز على القضايا و المتغيـــرات 


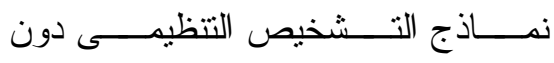

$$
\text { غير ها. }
$$

ب - اقتصرت الدراســة الميدانيــة علــى

محافظة الثرقية ، للأسباب الآتية :

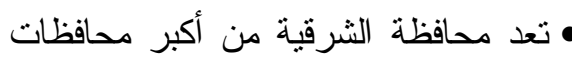

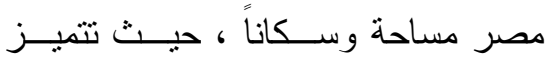

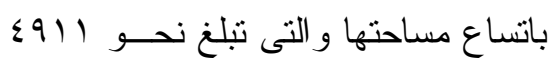

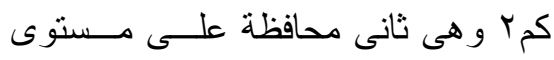

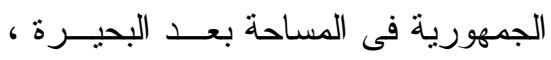

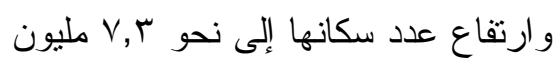

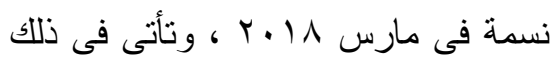

فى التزتيب الثالث مباشرة بعد القـــاهرة

$$
\text { و الجيزة . }
$$

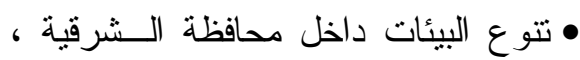

حيث يوجد بها البيئة الحضرية و الريفيــة

$$
\text { و الصناعية و الصحر اوية. }
$$

كما أنه من أهم مبررات اختيار الثرقية ، ما ولاهيه

$$
\text { يلى : }
$$

ا- يبلغ عدد المـــدارس الثانويــة العامـــة

الحكومية بالثرقية (•11/) مدرسة في

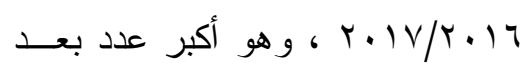

محافظة القاهرة.

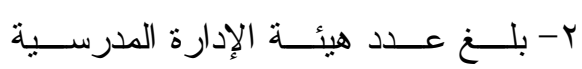

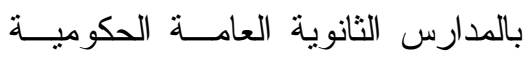

بالثرقية (YV9) ، في الترنيب الر ابــع

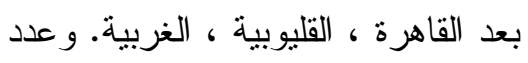

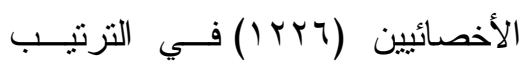

الأنــــــاع ، المر احـــل ، المتطلبــــات ، ومعوقات التطبيق .

- در اســـة وصــفية لنمـــوذج ويــسبورد

Six-Box Model للتشخيص التتظيمي وصنيه وبيان ماهيته و أهميته ومز ايا اســتخدامه

$$
\text { و أبعاده . }
$$

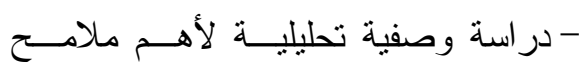

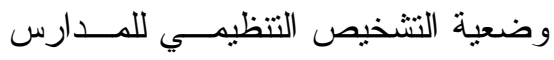

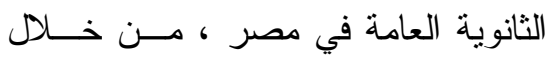

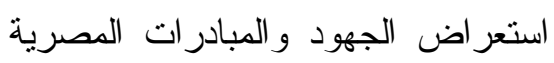

لتحسين أبعاد التشخيص التتظيمي ، و أهم

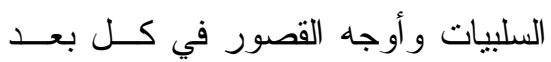

منها.

- در اسة ميدانية لواقع التشخيص التنظيمي

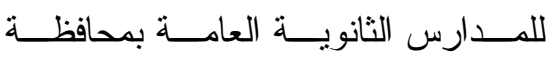

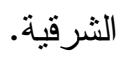

- وضع مجموعة من الإجر اءات المقترحة

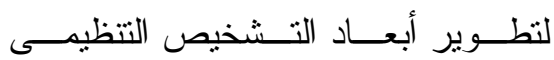
للمدارس الثانوية العامة بمصر في ضو أبع

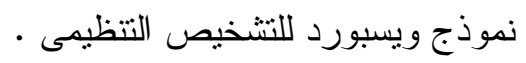

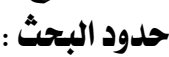

أ - نتاول البحث الحالى الأبعاد و المتغيـــرات

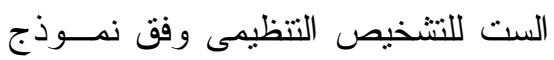

ويسبورد ، وهـى الأهــداف ، الهيكـلـل

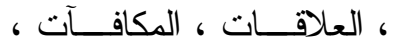

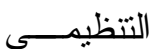

القيادة ، و الآليات المساعدة ، إذ لا يمكن

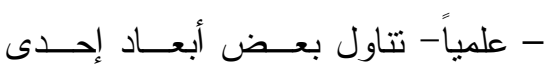


(مدر اءء ، وكــلاء ...) حــول و اقــع أبعــاد

التشخيص التتظيمى بالمدارس الثانوية العامة

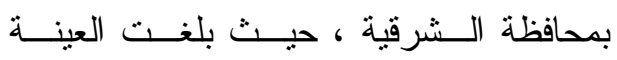

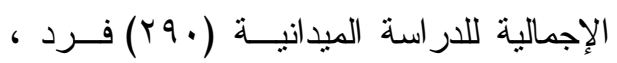

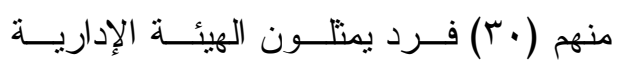

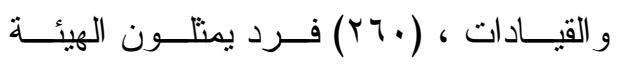

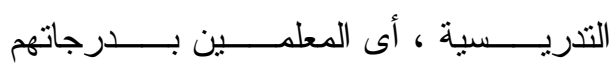

ومستوياتهم المختلفة.

مصطلحات البحث : ومن الثن

وضعت الدر اسة التعريفات الإجرائىة

النالىية :

التشخيص التظيمى :

إحدى الأدوات و الأساليب الإدارية النى : لإئى

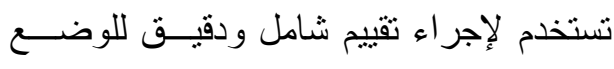

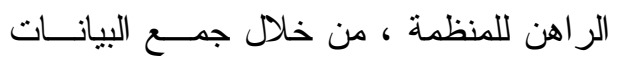

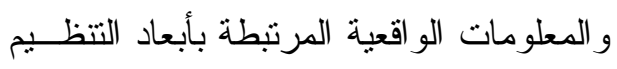

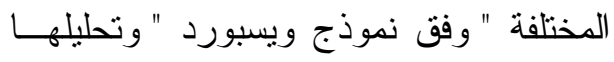

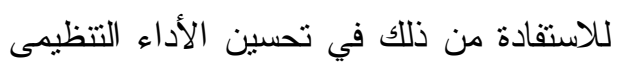

، وتحقيق التغيير و التطوير التتظيمى الفعال ،

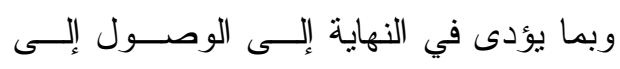

الصحة و الفعالية التتظيمية.

نموذج ويسبورد للصناديق الست للتشخيص وليه

التنظيمى : المودج وينيا

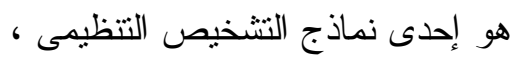

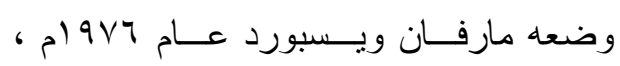

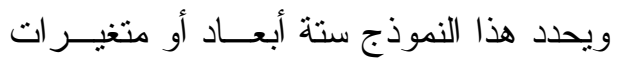

للتنظيم ، سماها ويسبورد بالصناديق الـست هـت
الثالث بعد القاهرة و الدقهليـــة ، بينمـــــا

عدد الإداريين (Y

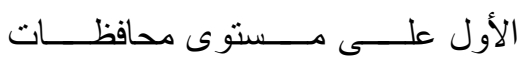
الجمهورية.

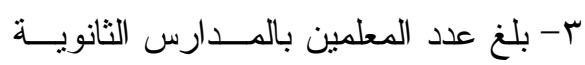

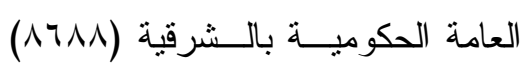

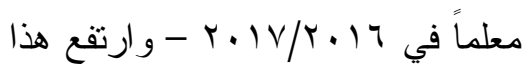

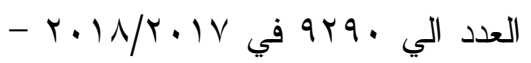

و هو أكبر عدد للمعلمين على مسستوى لعدي الجمهورية بعد محافظة القاهرة.

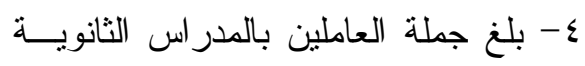

العامة بالثرقية مــن معلمـين و إدارة مدرسية و أخصائيين و إداريين و عمـــال

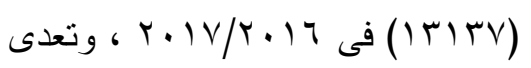

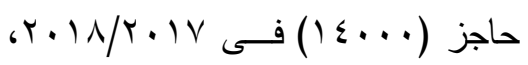
وهو أكبر عدد على مستوى الجمهورية بعد القاهرة مباشرة.

ه- يبلغ عدد الإدارات التعليمية بمحافظـــة

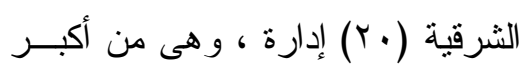

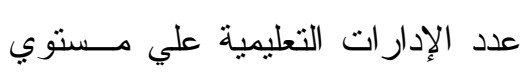

$$
\text { الجمهورية. }
$$

أداة الدراسة الميداتية وعينة البحث :

تم إعداد استبانة التشخيص التتظيهـى وعيله

وفق نموذج ويـسبورد للـــنـاديق الـست ،

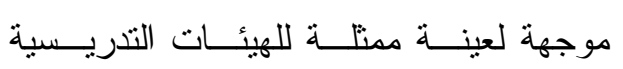

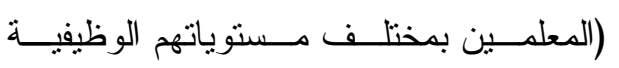

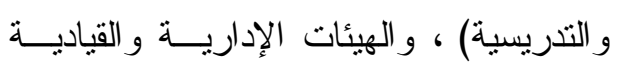


جو انب الضعف فــى التطــــير التنظيمـى ،

و واستخدمت المنهج الوصفى بطريقة المسح ،

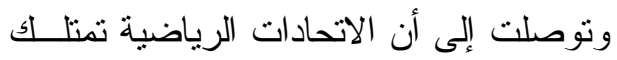

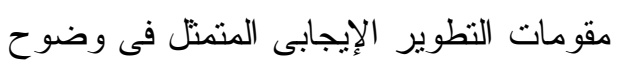

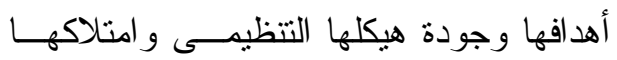
قيادات كفؤة وعلاقات وظيفية جيدة ، إلا أنها

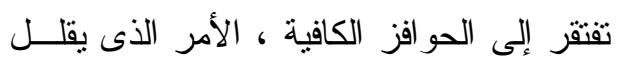
من دافعية الأعضاء نحو التطوير .

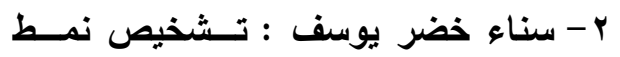

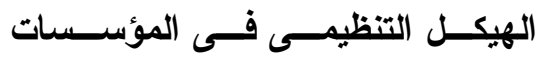

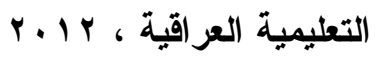

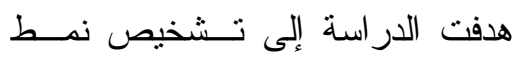
الهيكل التتظيمى فى جامعة صـــلاح الــدين

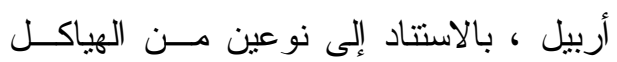

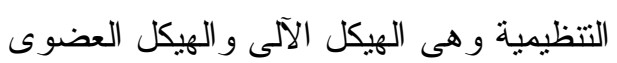

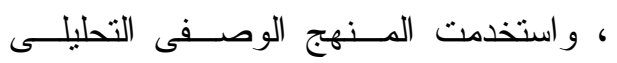

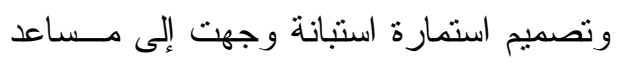

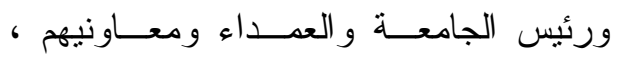

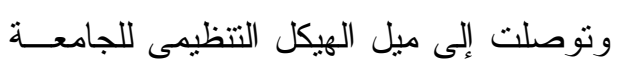
المبحوثة باتجاه سيادة مو اصفات الهيكل الآلى ولى لونى اعتماداً على قياس نتائج المتغير ات الفرعية.

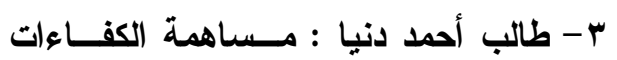
البثرية فى التشخيص الاستراتيجى فى

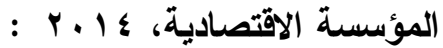

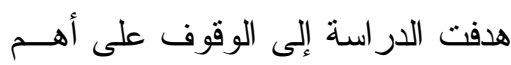

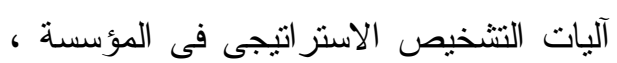

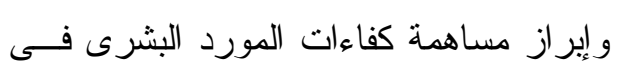

Six-Box و هى : الأهداف، الهيكل النتظيمى

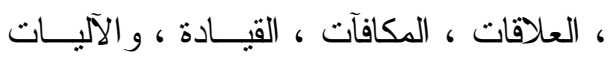

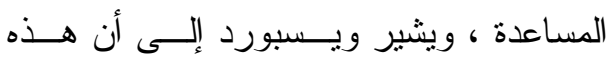

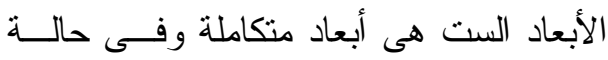
تقاعل مع بعضها البعض ، ويجب أن تكـــون

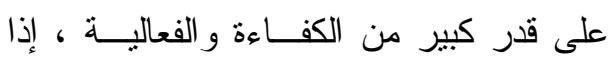

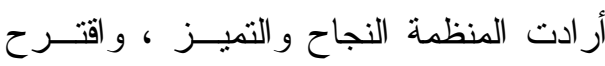

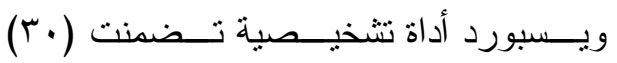
مفردة، يمكن الاستعانة بها لقياس ونقييم ومن

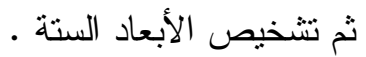
الدراسات السابقة : أولاً : الدراسات العاسية : العربية :

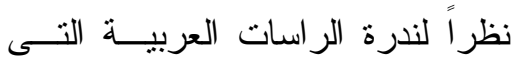

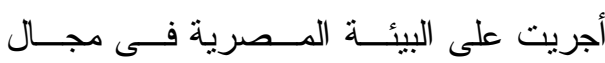

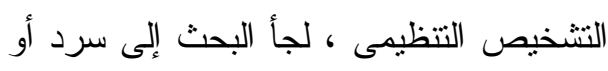
عرض بعض الدراسات السابقة التى أجريت

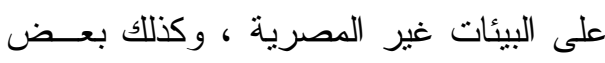

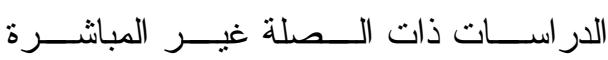

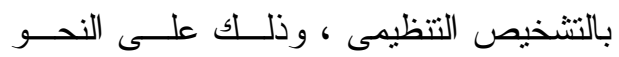
التالى : بالنت

1 - عدى غانم محمود الكـــواز : تـشخيص

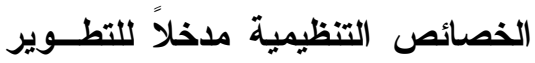
التظظيمى فـى الاتحـــادات الرياضــية

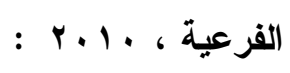

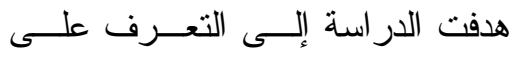

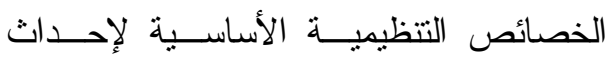

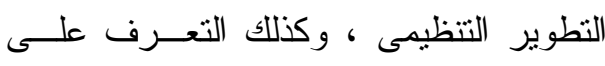


هدفت الدر اسة إلى تحديد تأثير أبعـاد

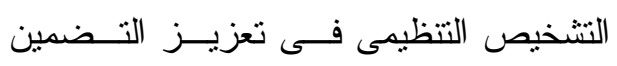

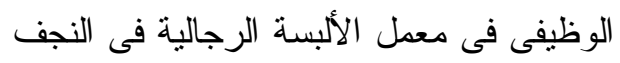

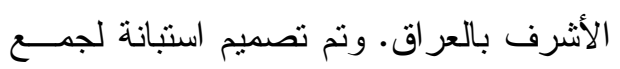

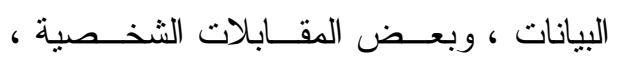

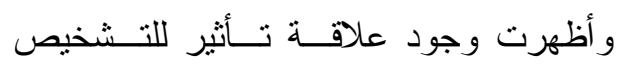

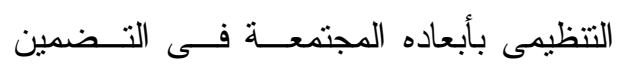

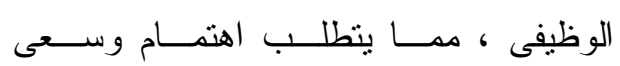

الإدارة بضرورة تطبيق وتتفيــذ اســتر اتيجية

، النتخيص التنظيمى على المستوى الوظيفى

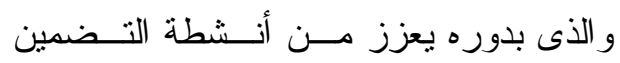

$$
\text { الوظيفى. }
$$

צ- معر قربة : التشخيص الاسـتراتيجى

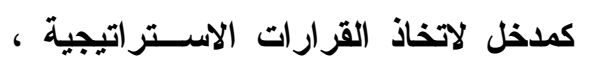

$$
\text { : r. IV }
$$

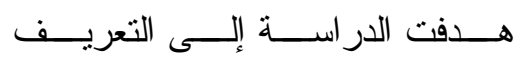

بالتشخيص الاستر اتيجى ، و الدور الذى بلعبه

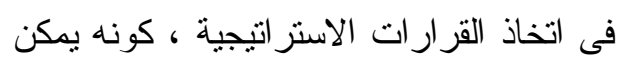
المؤسسة من تكوين قاعدة هامة للمعلومسات

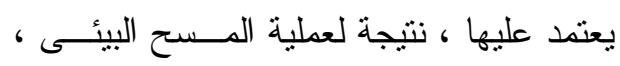

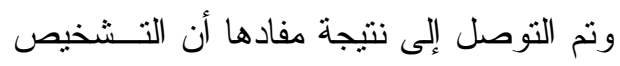

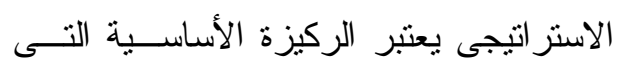

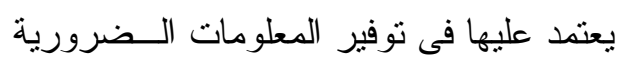

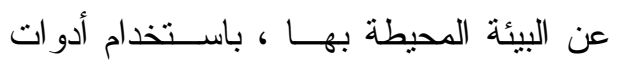

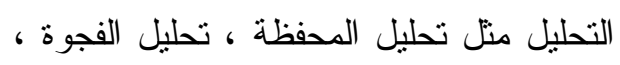

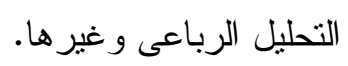

النشخيص الاستراتيجى ، و استخدمت المنهج

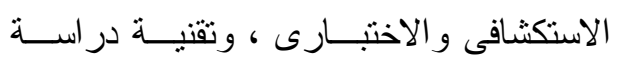

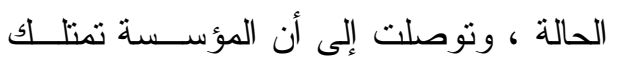
كفاءات بشرية ذات المعرفة النسبية العالية ، وأن إطار ات المؤسسة تقر بأهميــة التـسيير بالكفاءات ، إلا أنه ومع ذلك ماز الت المؤسسة تعتمد على الطرق التقليدية فى إدارة وتــسيير إطار اتها.

ع - فواريه بلبـشير : نمــاذج التـشخيص التنظيمى ودورها فى إعداد استراتيجية

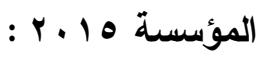

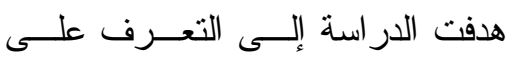

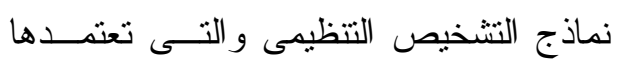

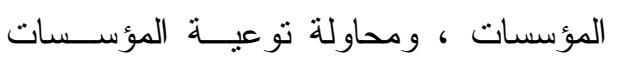

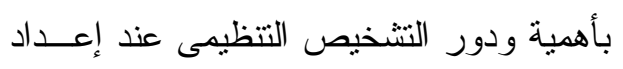
استز اتيجيتها ، و استخدمت أساليب البحــوث

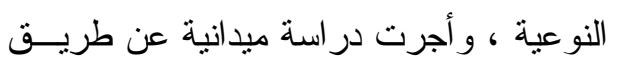

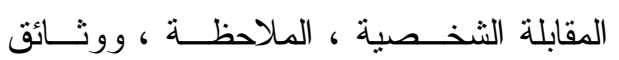

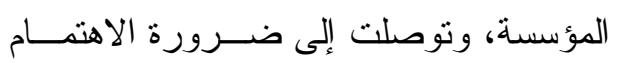

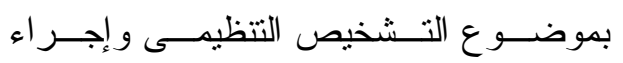
در اسات حوله لأنه ضرورة حتمية تقتـ ضيها الظروف الحالية التى تتميز بسرعة التغييـر و عدم التأكد.

ه- عمار عبد الأمير زويــن : التـشخيص

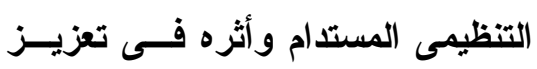
التضمين الوظيفى ، دراسة استطلاعية، 
r-جيمس م. ميكفلين : التشخيص التنظيمى

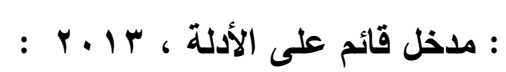

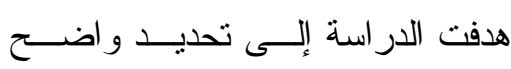

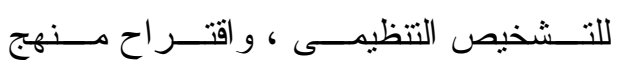

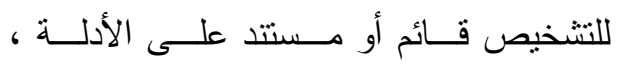

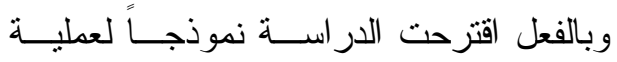

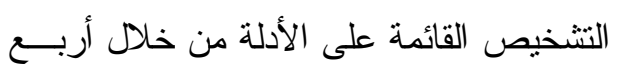

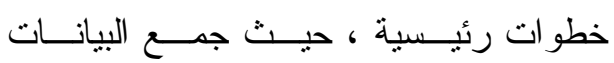

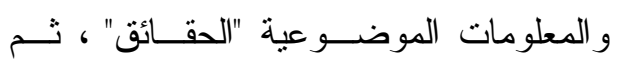
تفسير ها ، و الاستفادة من ذلك فـي تـشكيل

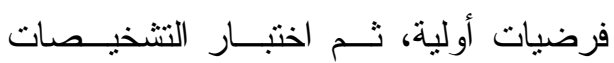
الأولية.

ع - بلال بن سعيد ، ونبن وانج : الإستدامة

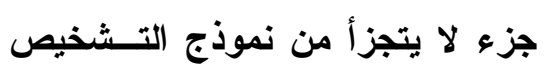

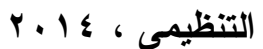

هدفت الدر اسة إلى وضـــع تـصور

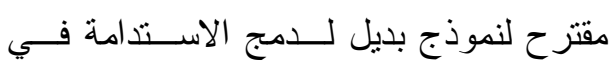

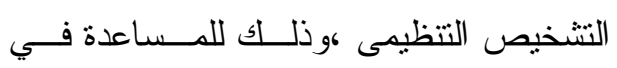

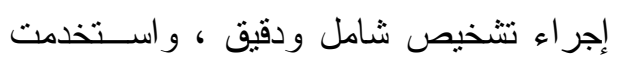

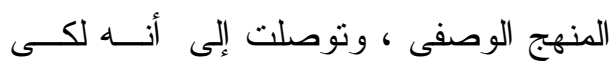

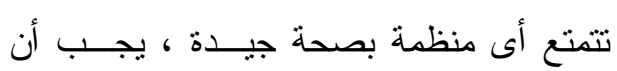

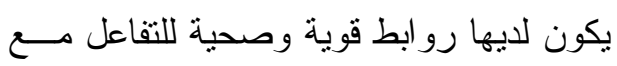
محيطها البيئى ، وذللك لفهم التغير ات وكيفيــة

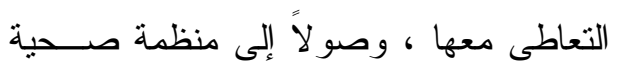

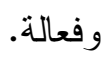

ثانياً : الدراسات الأجنبية :

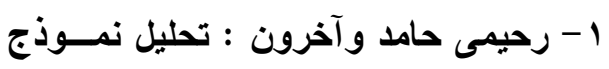
الصناديق الست للتشخيص التنظيمسى وحلى

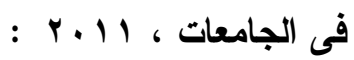

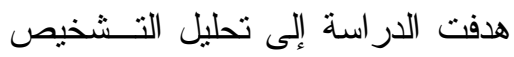

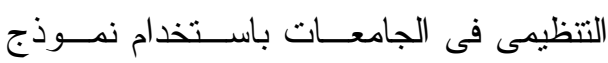
الصناديق الست ، و استخدمت المنهج الوصفى لهي المسحى وطبقت در اسة ميدانية على (Y) (Y)

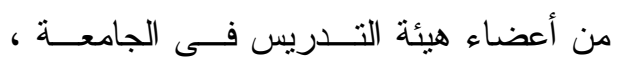

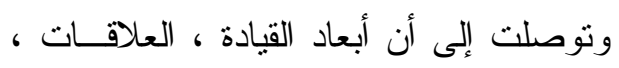

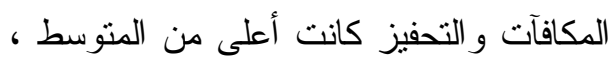
أما بعدى الأهداف و البنية التتظيمية أقل مـن التهن المتوسط. r - فيدا كركور تيتح : التشخيص التنظيمى

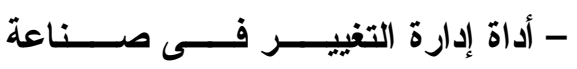
الاتصالات، r I r :

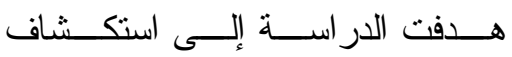

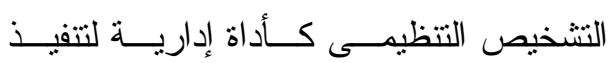
عمليات تغيير كبرى ، و الدور الـــى يؤديـــ

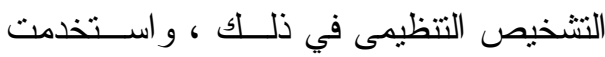

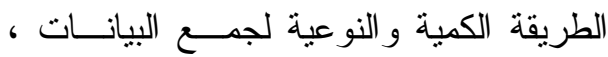

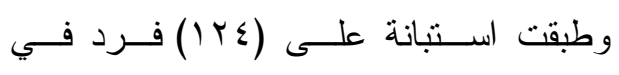
المؤسسة، وتوصلت إلى اتفــاق المؤسـسـات على أن ادخال منتجات وخدمات جديدة ، هو

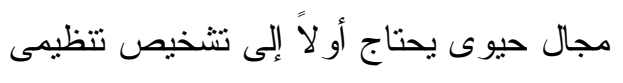
فعال. 
كل الدراسات السابقة أجريت على بيئات غير البيئة المصرية ، كما تتاولت معظمهــا عـدة التهات

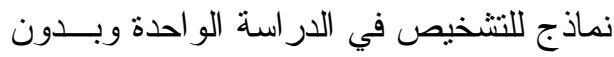

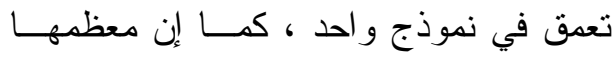

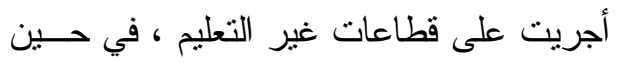

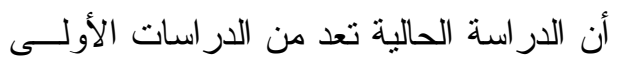

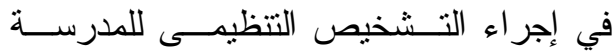

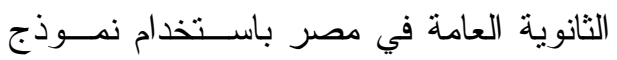

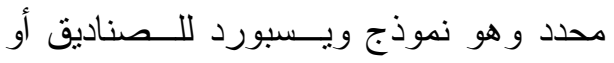
الأبعاد الست ، مع تطبيق در اسة ميدانية على ولى

محافظة الشرقية. خطوات البحث : يسير البحث في الخطوات التالية :

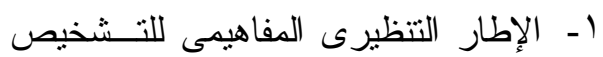

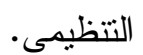

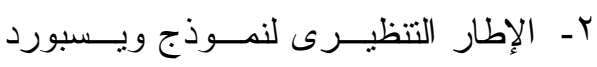
للصناديق الست للتتخيص التتظيمى.

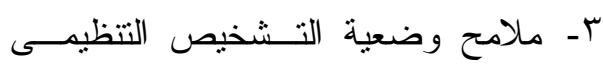

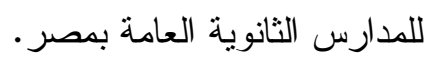

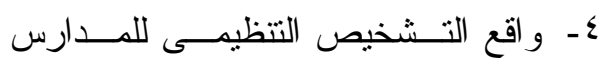
ميدانياً. هـ الإجر اءات المقترحسـة لتطــــير أبعــاد

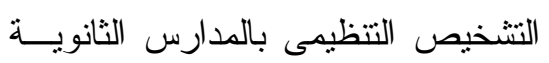
العامة وفق نموذج ويسبورد.

الخطوة الأولى : التثخيص التنظيمى : إطار تنظيرى مفاهيمى :

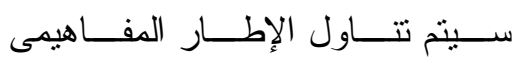

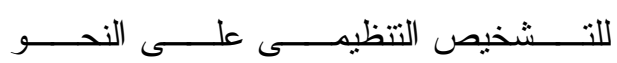

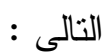

ه-جينجكسيو زانج وآخرون: إطار تثخيص متكامل لإدارة التنمية المستدامة للمنظمة : ( $r$. 1 7$)$

هدفت الدر اسة إلـــى تطــــوير إطـــــار

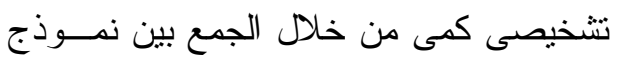
ويسبورد للــصناديق الـست ونمـــوذج إدارة التتمية ، بالتزكيز على المؤسـسـة داخليــاً ،

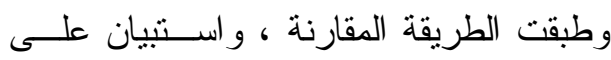

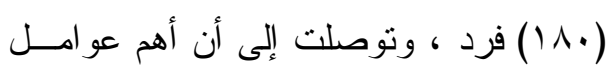

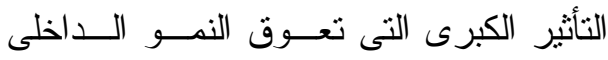

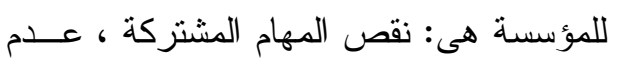
وجود وحدات عمل فرديــة ، ســو ء تقــسيم

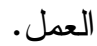
צ- كوليمان سى.أ : التشخيص التنظيمى فى

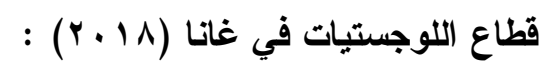

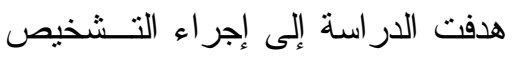

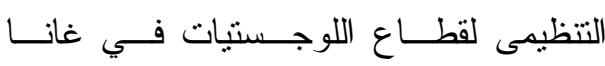

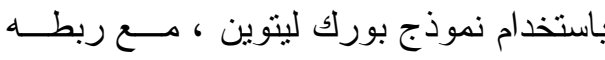

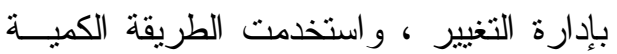

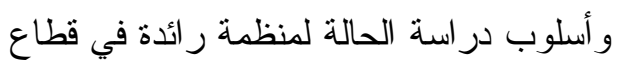
الخدمات اللوجستية ، وكذلك تطبيق اسـنبيان على (T) فرد ، وتوصلت إلى أن أية مبادرة

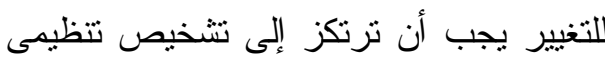

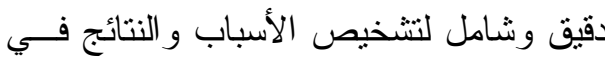
إطار السياق الداخلى و الخارجى للمؤسسة. التعليق على الدراسات السابقة :

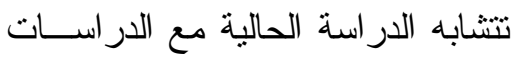

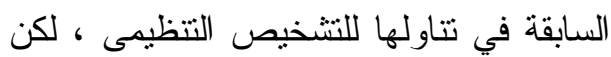
ثمة اختلاف واضح في عدة أبعاد ، أهمها أن 
من خلالها توليد معلومات صـــالحة ومفيــدة حول الأنظمة التتظيمية .

وتنخيص المنظمة بعنى تقييم صـــحة

المنظمة ، بما بـــؤدى إلــى زيـــادة الفعاليـــة

التتظيمية ، باعتبار ها إحدى مؤشر ات الصحة

التتظيمية ـ ومن ثم لا يمكن أن تتحقق الصحة

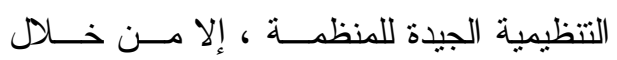

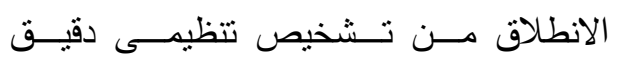

$$
\text { و موضوعى وو اقعى أولاً. }
$$

ويعتمد التشخيص التنظيمى على جمع

البيانات و المعلومــات المتعلقــة بالعمليــات

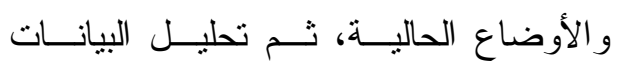

واستخلاص اســتنتاجات حــول التغيــرات المحتملة ، ثم وضع الإجــر اءات و التــدابير

الصحيحة .

و النتخيص التتظيمى جزء من عملية

أكبر و أوسع وهـــى إدارة الأداء ، باعتبـــاره

عملية تهدف إلى قياس وتقييم أداء المنظمة .

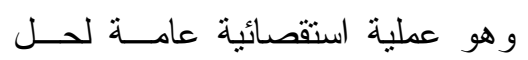

المشاكل التتظيمية داخل المنظمات ، وتتطوى على ثلاثة أشكال أو أبعاد :

1- المعرفة المفاهيمية : النظرية ونمــاذج

التأثير و الأسباب و المشكلات.

r- معرفة مظاهر المــشكلة و الأعــر اض واض

$$
\text { و المسببات. }
$$

ب- المعرفة الإجرائية :حيــث منهجيــات

الاختيار و البحث و الحلول و العلاج.
أ- مفهوم التشخيص التنظيمى :

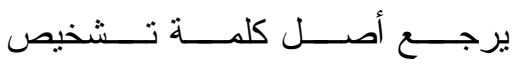

Diagnostic

دياغوستيكوس Diagmosis ، حيث اثــتقت منها ، و التى تعنــى القــدرة علــى التمييــز - Aptitude au Discemement

و التشخيص التظظيمـى مـسـتمد مــن

مدرسة هيوكر اتس ، وارتبط فى بداية ظهوره

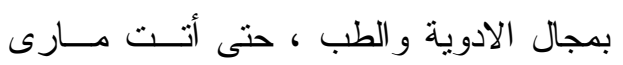

ريتشموند Mary Richmond و اســتخدمته

لأول مرة فى العلوم الاجتماعية، حيث كانت

تؤهن بالعلاقة الوثيقة بين الأفــر اد وبيئــاتهم

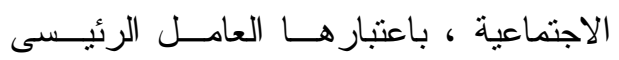
لوضعهم الحالى . ل ل

وقد انتقل التشخيص إلى مجال الإدارة

خلال فترة السبعينيات من القرن الماضــى

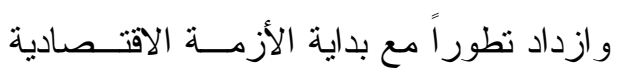

العالمية.

و التشخيص التنظيهـى عبــارة عـن

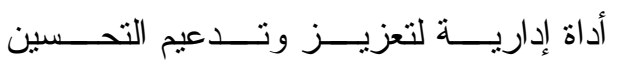
و التطوير و التغييــر التتظيهـى مــن أجــل الاستدامة . ول.

ونظر إليه البعض على أنه اسنز اتيجية

تستخدم لتحسين الأداء التتظيمى مــن خـــلاله

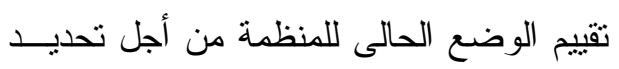
التذخلات الأنسب للتطوير ، وهو عملية بــتم 
على أن يتم كل ذللك فى ضوء معايير التنظيمى ، فلا تغيير تتظيمى نـاجح بــدون كمية وكيفية تتم فى ضوئها عملية التشخيص. تشخيص نتظيمى دقيق.

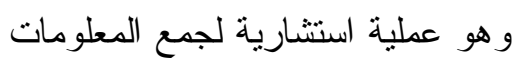
ونظر إليه أحد البــاحثين علــى أنـــه

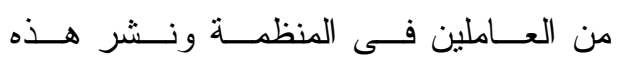
مجموعة من الخطط التى تعتمد على المفاهيم

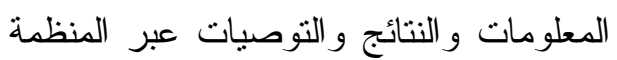
و الأدبيات و النماذج ومناهج العلوم الـسلوكية منسية

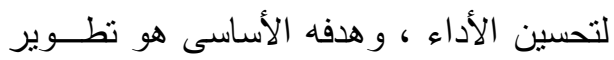

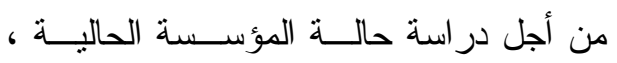
الفهم المشترك حول المنظمة ، وتحديد ما إذا لهادئ

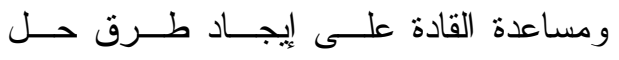

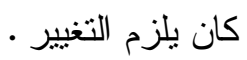
ويعد التنخيص التنظيمــى المرحلـــة

الإفتتاحية لعملية التغيير التنظيمى ، حيث يتم

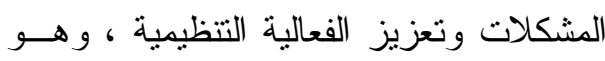

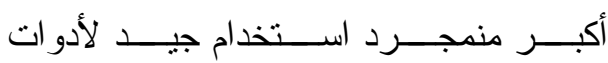

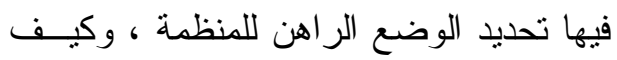

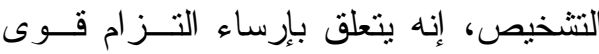

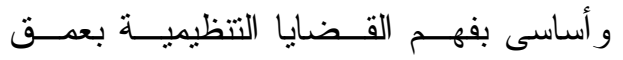

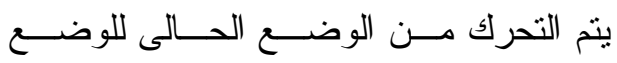
وممارسة التحقق التنظيمى الصارم و الحاسم •

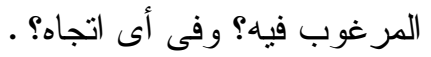

وبوجــه عــام ، يجيــب التـشخيص

يلاحظ مما سبق تنوع نظرة البــاحثنين

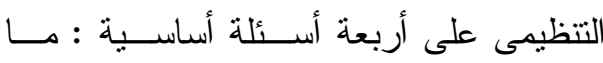

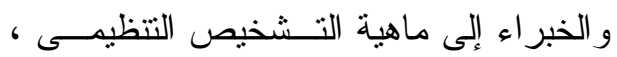
فمنهم من نظر إليه على أنه مجرد أداة لتقييم

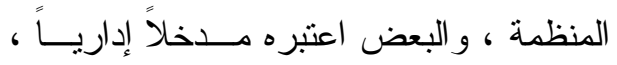

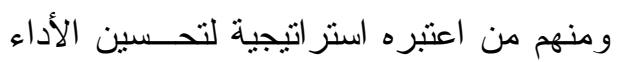

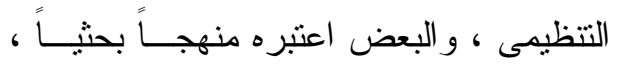

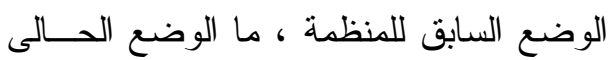

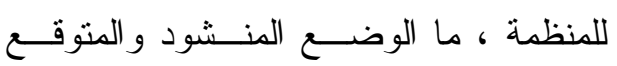

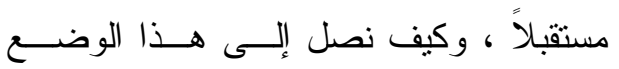

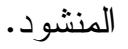
و البعض نظر إليه على أنه عملية استقصائية

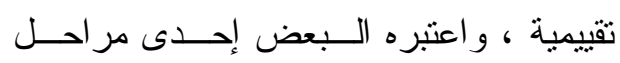

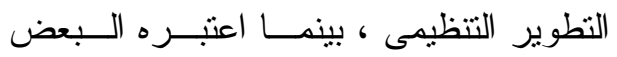

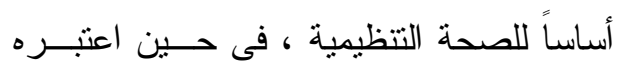

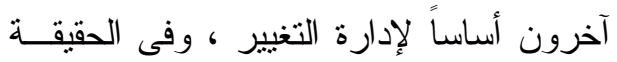
يمكن النظر إلى النتخيص التنظيمى على أنه النه واعتبر البعض التشخيص التتظيمسى منهج بحثى يدور حول الوقوف علــى تقيــيم

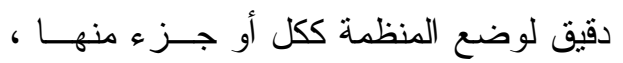

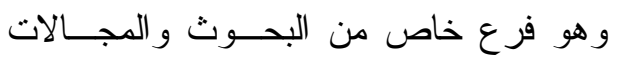

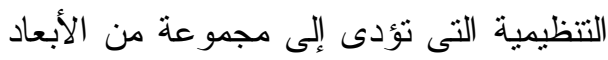

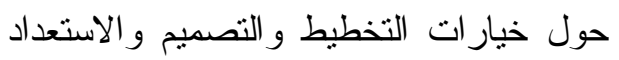

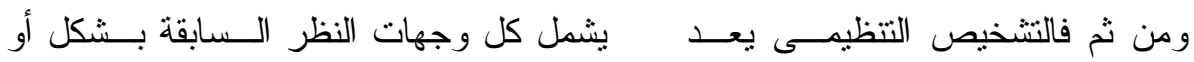

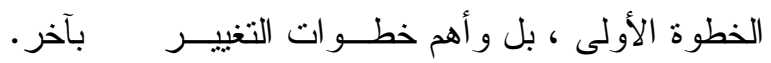


- يسهم فى فهم وتقييم المشاكل التنظيمية ، ونمية

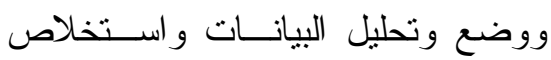
النتائج ، بهدف إجر اء التغييرات النازيل ولتهة

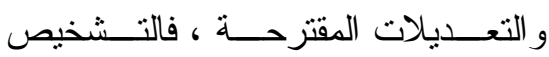

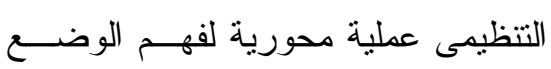
الحالى للمنظمة وتقييم مشاكلها ومعرفــــة أسبابها ، ومن ثم وضع الحلول الملائمة لها .

- يعد التشخيص التنظيمى جزءً لا يتجــز أ

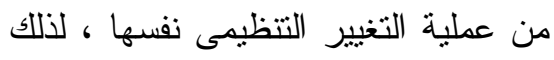

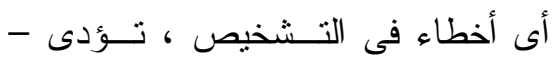

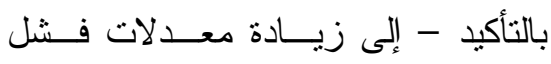

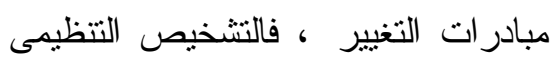

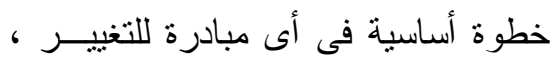

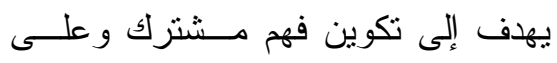
نطاق و اسع لمنظمة ما ، وبناءً على هذا الفهم يتحدد ما إذا كان التغيير مرغوبـــاً

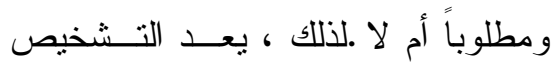

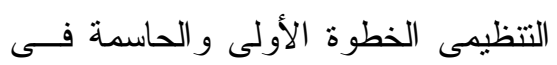
التخطيط للتغيير ووضع اســنز اتيجياته ، استتاداً إلى تقييم شامل ودقيق ومتكامـلـل لكافة أبعاد وجو انب العمل التتظيمى. - يتيح التشخيص التتظيمى نماذج وأطـــر تتظيمية للتعامل الـسليم مــع الـــشاكل و القضايا التظظيمية بشكل مخطط ومنظم ومنهجى ، بالاعتماد على نظريات العلوم السلوكية ، تساعد هذه النماذج فى نتظيم بلاعيد
وفى ضوء ما سبق يــضع البحـث

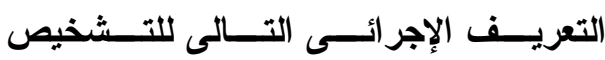
التنظيمى، هو إحــى الأدوات والأســاليب

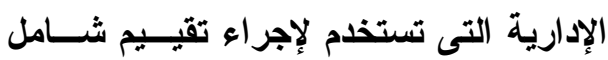

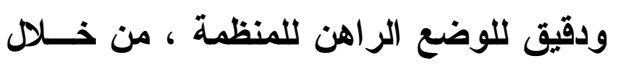

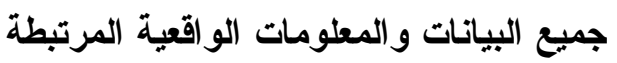
بأبعاد التنظيم ومحاوره الست المختلفة كما

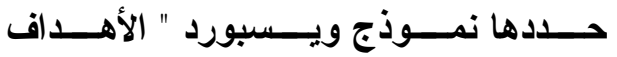

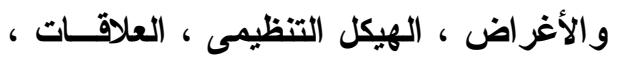

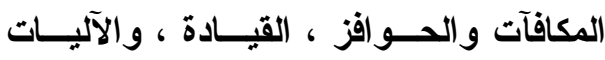

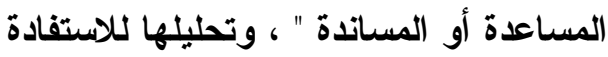

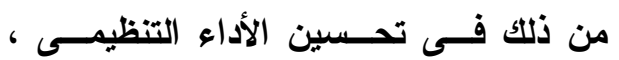
وتحقيق الفعالية والصحة التنظيمية.

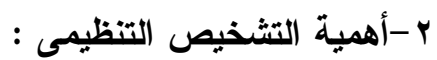
يمكن إيراز ملامح أهمية التـشخيص

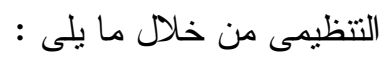

- يعد التشخيص التتظيمى المفتاح الأساسى لئحس

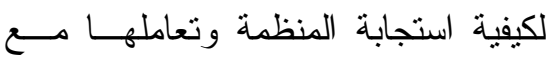
ضغوط المنافسة من البيئة الخارجيــة ، وكيفية الاستجابة للتغيير •

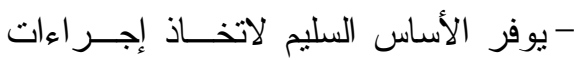

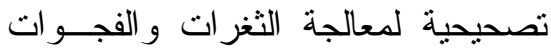
التى تظهر من خلال الثقييم و التـشخيص

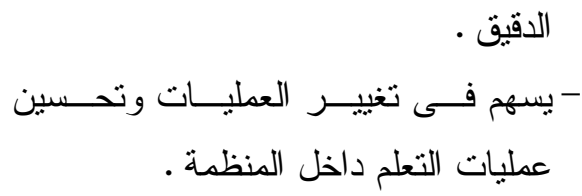


- تجنب ردود الفعل الخطيــرة فــى بيئــة

$$
\text { العمل غير المؤكدة. }
$$

- تجنب إحداث عملية تغيير غير سليمة.

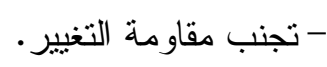

- مساعدة المديرين على تحديد الإجراءات الأكثر ملاءمة للرد على اضطر ابات بيئة

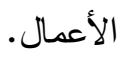

يتضح مما سبق مدى أهمية النتخيص الاعمان

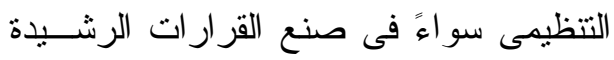

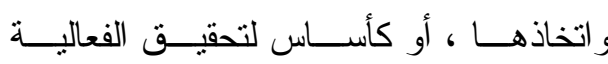
و الصحة التتظيمية ، أو للمساهمة فى إحداث التغيير و التطوير التنظيمى المنشود، وتحسين عمليات التعلم التتظيمى ، و اتخاذ الإجـــر اءات

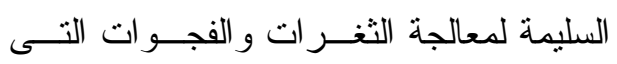
يكثف عنها التشخيص التتظيمسى الــدقيق ،

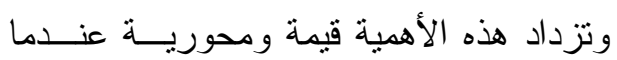

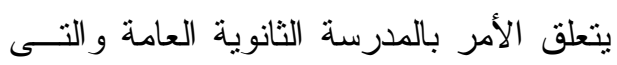

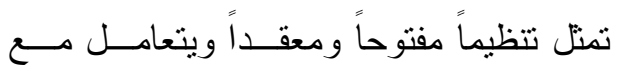
طلاب ذوى طبيعة خاصة وفى مرحلة حرجة

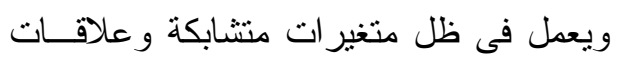
منسعة ، مع تتوع و اضح فى أبعاد ومكونات

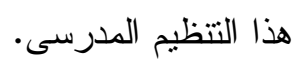
r- أهداف التشخيص التنظيمى : يهدف التشخيص التظظيمى إلى تحسين

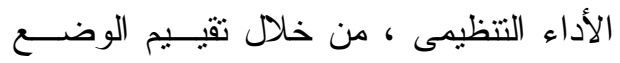

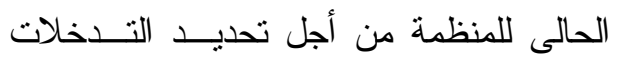

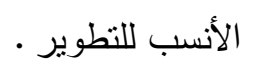

كميات هائلة من المعلومــات لمسـاعدة المديرين و الممارسين ومسئولى التغييــر مئر و التطوير على فهم المــشاكل و الحقــائق ودئق التظيمية . - يعد أساساً لعملية صنع القرار و اتخاذه ،

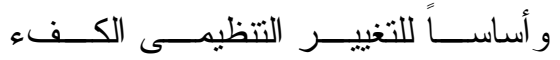
و المستتير ، كما يستخدم كأساس فى تقييم

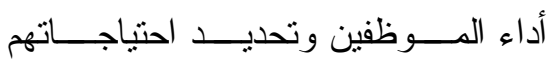
التذريبية . ومن ثم يؤدى التشخيص التظظيمى الجيد إلى صنع و اتخاذ قر ار ات رشيدة ، تشنتد

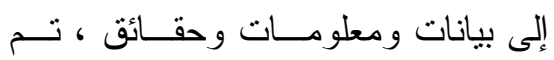
استخلاصها من خلال تقييم شامل ودقيق ومعلى وهات لوضع المنظمة.

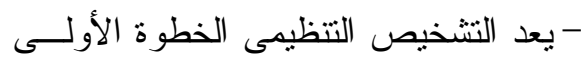

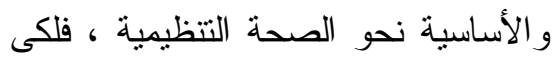
تكون المنظمة فى صحة جيدة ، لابد أن يكون لها رو ابط وعلاقات قوية وصحية

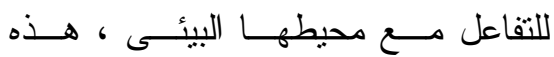
العلاقات و التفاعلات و الاتصالات نساعد

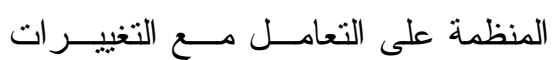
و التكيف معها .

ويلورت إحدى الدراسات أهمية التـشخيص

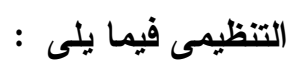

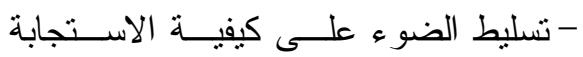
السريعة لمتغير ات قوى السوق. 
هى الأدو ات و الآليات الأفضل لزيادة فعاليــة

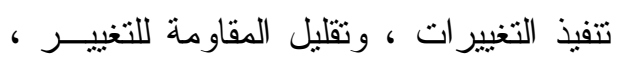

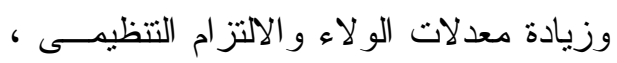

وكذلك معدلات الرضا عن العمل .

وجمعت إحلى الدراسات أهداف التـشخيص

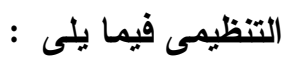

- التعرف على مز ايا وعيوب سير عمـلــل

المؤسسة.

- تحديد المـشـاكل التتظيميــة التــى مــن

المحتمل أن تظهر مستقبلاً.

- تحديد نقاط القوة و الضعف فى المؤسسة

حتى تستعد للتغيير

- تحديد ما الذى تريد المؤسسة تحقيقه وما لـأ

$$
\text { التغيير المرغوب وكيفية إجر ائه. }
$$

- تقييم الفعالية التنظيمية واقتــر اح الــسبل

$$
\text { لتحسينها. }
$$

- وضع خطة عمل للمستقبل.

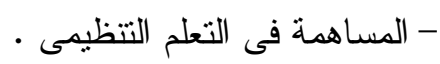

ومن ثم تتعـدد أهــــاف التـشخيص

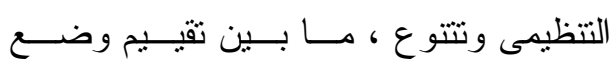

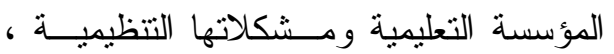

المساهمة في تحقيق كل من التعلم التتظيمى ،

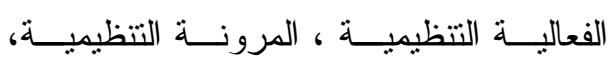

و الصحة التنظيمية ، إضافة إلى تحسين الأداء

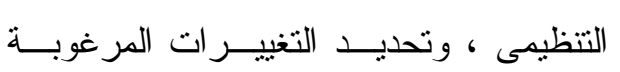

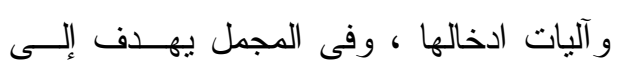

ويعد التشخيص التظظيمى أداة إداريــة

فعالة لتعزيز وتـــــيم التحــسين و التطـــــير

و التغيير التنظيمى من أجل استدامة المنافسة .

وللتشخيص التتظيمى هدفان رئبسيان،

الأول : تقييم الخلل التنظيمى ، و الثانى : تقييم

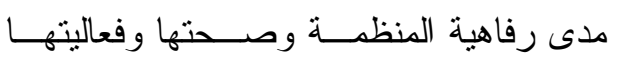

التظظيمية .

ويهذف التثخيص التنظيمى -أيضاً - إلـى : مالـ

ما يلى :

- تحقيق الميزة التتافسية المستدامة.

- تحقيق الفعالية النتظيمية ومن ثم الصحة

التنظيمية.

- تحسين أداء النظام ككل.

-وضع تـــابير وإجــراءات تــصحيحية

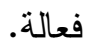

فالتشخيص التتظيمى بهذف إلى إعطاء

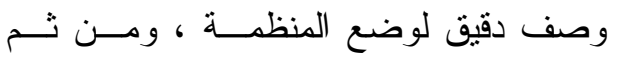

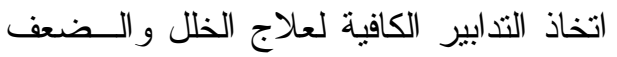

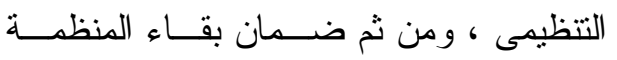

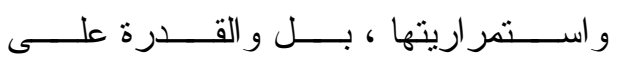

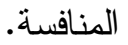

و النتخيص التنظيمى لا بـسمح فقـ ط

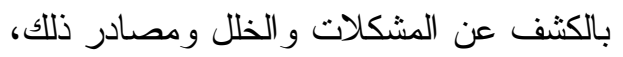
و إنما يساعد على إعداد الأفراد - مديرين أو لون

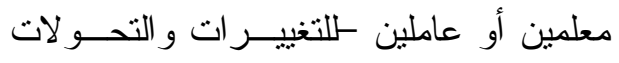
الضرورية ، كما تساعد نتـائج التـشخيص

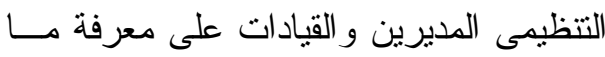


و التصورات المـشتركة بــين الأفــراد العاملين داخل المؤسسة.

- يمتل الخطوة الأولى مــن عمليــة بنــاء الموله

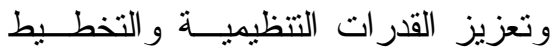

$$
\text { الاستر انتجى للمنظمة. }
$$

ومن ثم فالتشخيص التنظيمى للمؤسـسـة التعليمية يتسم بأنه عملية دورية مستمرة شاملة ومتكاملة، يشترك فـــي إجر ائهــا

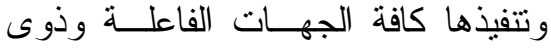
العلاقة ، و هو إحدى خطــــــات التغييــر و التطوير التتظيمى • - أنواع التشخيص التنظيمى :

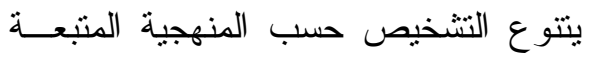
و الزاوية التى ينظر من خلالها المـشخص

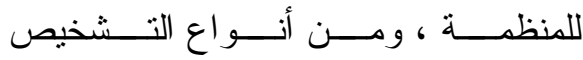
ما يلى : - التشخيص الاستراتيجى :

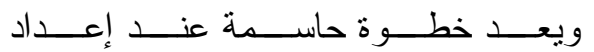
الاستر اتيجية، ويسمح للمنظمة بمعرفة مـــا

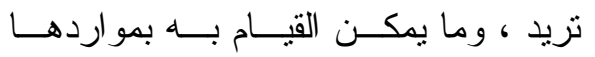

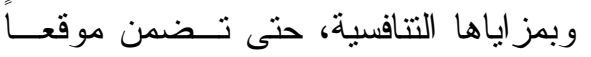

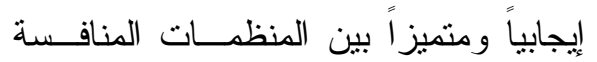

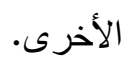
- التشخيص الوظيفى : ويهذف إلى فحص وتوصــيف وظيفـــة أو وظائف معينة بالمنظمة ، بهدف استخلاص

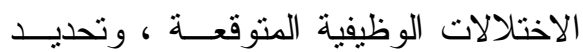
نقاط قوتها وضعفها ، التى تساعد في اتخاذ إجر اءات تصحيحية وبناء أهداف مسنقبلية.
تحقيق الميزة التنافسية المـستدامة للمؤسـسـة

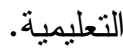
ع -خصائص وملامح التشخيص التنظيمى : يتـــسم التــشخيص التنظيمــى بــــالملامح والخصائص التالية :

- التشخيص التتظيمسى عمليــة جماعيــة

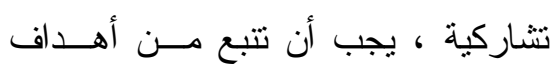

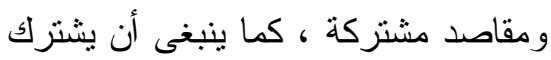

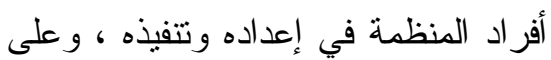
النقيض من النشخيص الطبى لا يـسنلزم

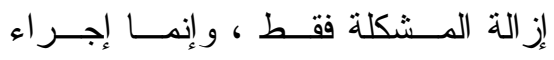
تغيير ات وتعديلات و أخذ مسار ات جديدة

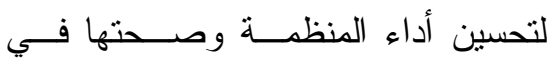
المستقبل . - التشخيص التنظيـــى عمليــة مـستمرة ومستدامة ، ويجب أن ينم بصفة دورية .

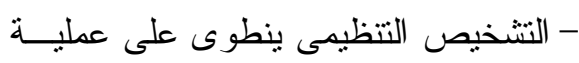

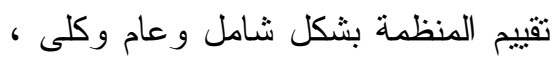
وليس مجرد تقييم وحدة فرعية محسددة فقط .

وبلورت إحدى الارسات مميزات وملامــح التشخيص التنظيمى فيما يلى :

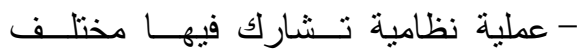
الجهات الفاعلة و أصحاب المصلحة.

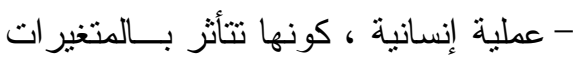

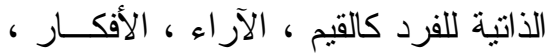


7 - مراحل وخطوات التشخيص التنظيمى : يمر التـشخيص التظظيـــى بالمراحـل التالية : - جمع البيانات و المعلومات : ويتم ذللك من خلال مجموعــة مــن الأدو ات و الأساليب المتتوعة منل الإسنبانات، الملاحظة ، الوثائق ، المقابلات و غير ها. ويعتمد الثخص على مصادر داخليــة

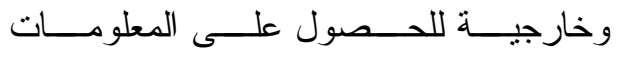

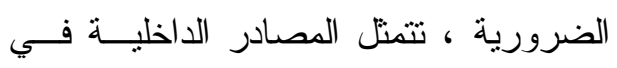

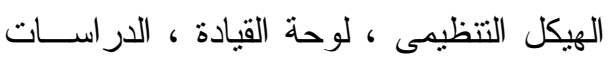

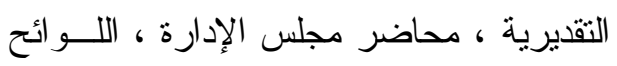

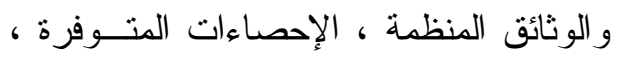
ومن المصادر الخارجية ، بنوك المعلومات ، در اسة الثقارير ، الدوريات و المنشور ات ذات

$$
\text { الصلة و غير ها. }
$$$$
\text { - تنظيم المعلومات : }
$$

وتتم من خلال ثلاثة جو انب رئيسية هى : • تصميم الإجر اءات لمعالجة المعلومات.

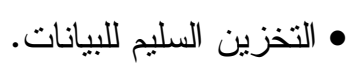

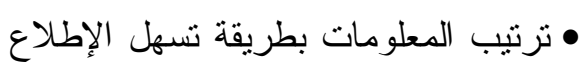
عليها. - تحليل وتفـسير البيانــات والمعلومــات والإحصاءات :

وذلك من خلال مر اجعة البيانات للتأكد من سلامتها و استكمالها ، ثم تجهيز البيانــات

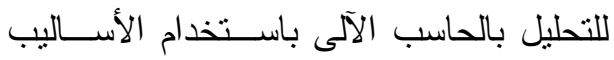

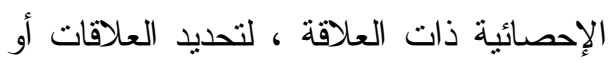

- التشخيص الإدارى : تقوم الإدارة العليا بإتاحة الفرصة لرؤســاء

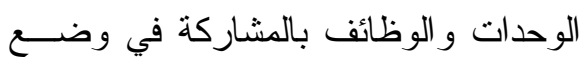

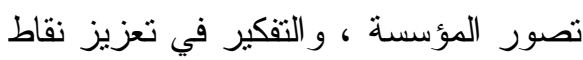
القوة و الحد من نقاط الضعف.

$$
\text { - تثخيص الهوية: }
$$

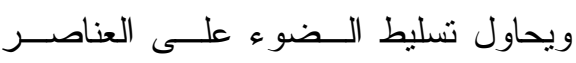

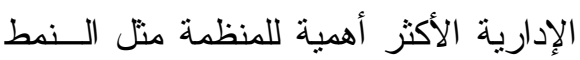
الإدارى ، التنظيم، الاتصالات و المعلومات، الإدريه الهنه التقافة التنظيمية. - التشخيص التكنولوجى : من خلال تشخيص الممتلكات و المكت نسبات التكنولوجية و التقنية ومدى الاستفادة منها. - التشخيص الثامل : وهو تـشخيص يجمــع مختلــف أنـــواع التشخيص ، ويمثل رؤية كلية للمؤسسة من أجل تتميتها وتطوير ها. ومن ثم توجد أنواع عديدة للنتخيص

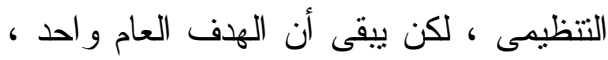
وهو اكتثاف نقاط القوة وتدعيمها ، ونو احى لهى لهي

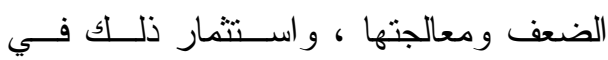
تطوير المؤسسة التعليمية وتحقيــق تميزهـــــا. ونموذج ويسبورد الذى تتبناه الدراسة الحالية

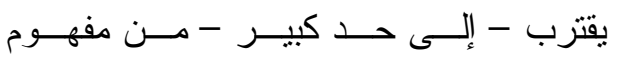
التشخيص الثامل و المنو ازن ، لنتاوله ســتة

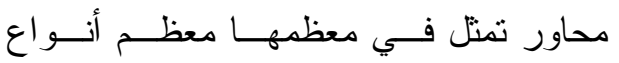

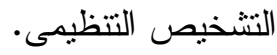


التغيير و القائمين على التطوير بالــصلة الحرجة و الحيوية بين التشخيص و التغيير التظظيمى الفعال في المنظمة .

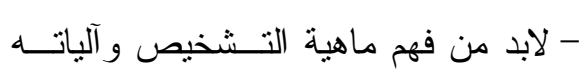
ودو افع القيام به ، كما أن تحديد المشاكل و علاجها ، يجب أن يتم بـشكل منــنظم

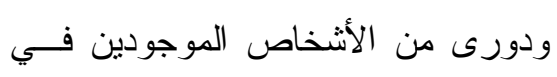

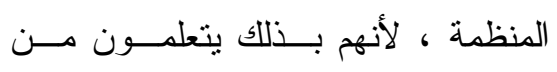

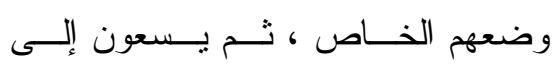

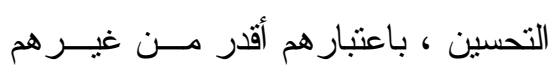
على التشخيص و التحليل . - ينبغى إجر اء التـشخيص بـشكل دورى

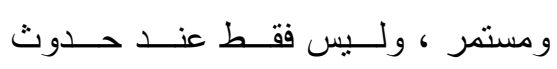
مشكلات أو وجود اخــتلالات ، و وإنمــا أيضاً عندما تبدو المنظمة صحية وفعالة .

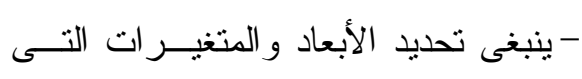

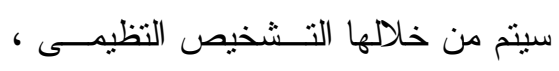
وأن تكون هنالك معايير موضوعية على خلى مدى كفاءة هذه المتغير ات و الأبعاد .

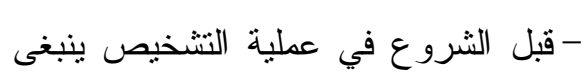

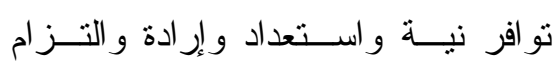

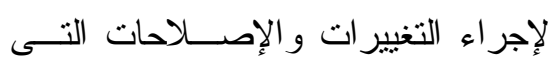

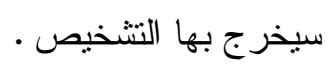
- يجب تيسير آليات الحصول على البيانات

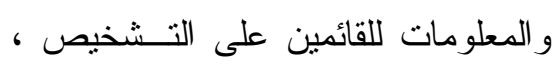

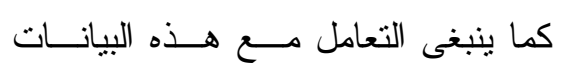

الاختلافات ، أو استخر اج بعض المؤشــرات

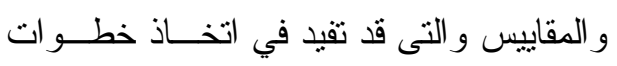
التغيير أو النطوير أو الإصلاح.

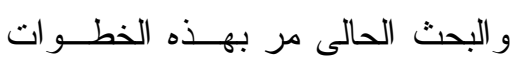

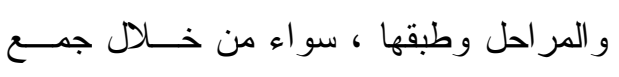

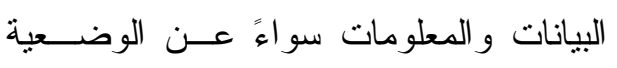

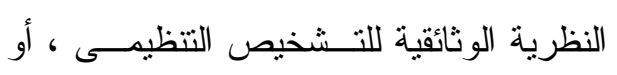
البيانات الميدانية ، ثم تم تصنيف هذه البيانات في جداول توضيحية ، ثم تحليـل البيانــات

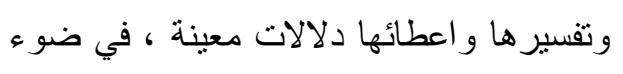
فهم الو اقع ومتغير اته و أبعاده وتحدياته.

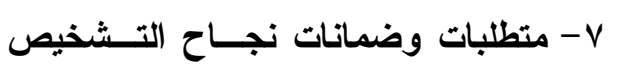
التنظيمى : من أهم متطلبات نجاح عملية النشخيص التتظيمى ما يلى :

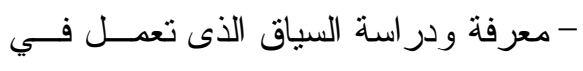

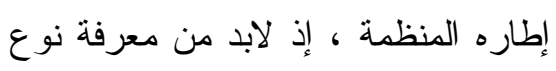

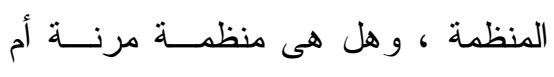

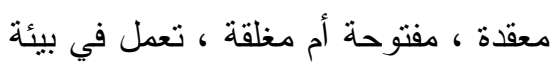

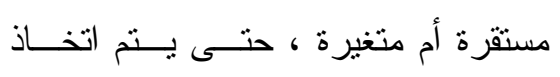

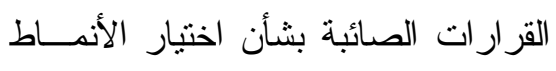

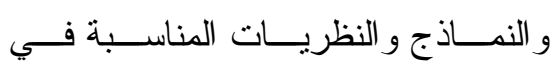
التشخيص و و - ينبخى أن يكون هنــاك تـدريب فعــال وحاسم على طــرق ونمــاذج و آليــات

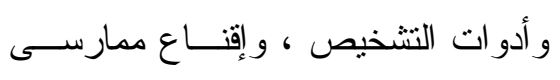


- قناعة بعض القيادات وممارسى التطوير

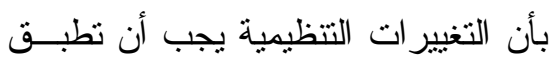

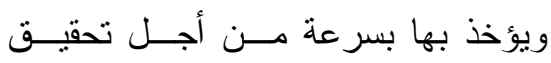

$$
\text { مكاسب سريعة وفورية. }
$$

- اعتقاد الأفراد المسئولين عــن التغييــر

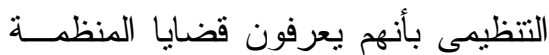

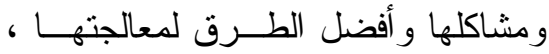

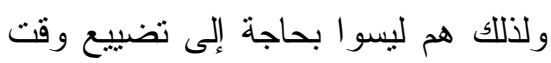

في النتخيص التنظيمى.

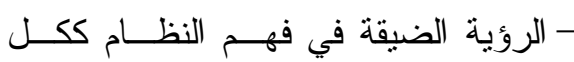

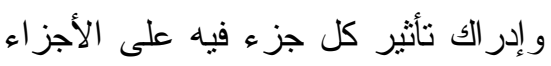

$$
\text { و العناصر الأخرى. }
$$

وتناولت إحدى الارسات مآخذ التشخيص الاحرى

$$
\text { التنظيمى كما يلى : }
$$

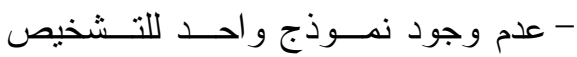

$$
\text { التتظيمى. }
$$

- عدم استعداد الجماعات التنظيمية داخـلـ

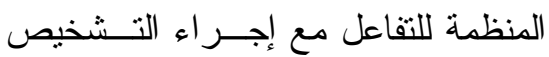

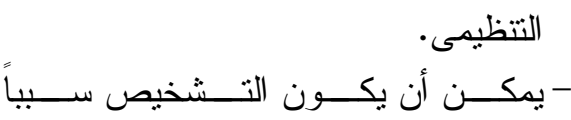

$$
\text { للصر اعات التنظيمية. }
$$

- يمكــن التلاعـــب بنتـــائج التــشخيص

$$
\text { التتظيمى. }
$$

ويرى البحــث الحسالي أن مــن معوقــات

$$
\text { التشخيص التظظيسى أيضاً ما يلى : }
$$

- عدم اقتتاع أو إيمان القيادات العليا بأهمية

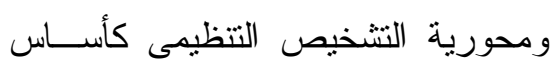
للتغيير و التحسين و التطوير التتظيمى.
و المعلومات و الإحصاءات بسرية تامة ،

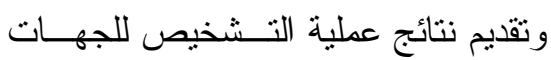

التى وفرت المعلومات و التى تعد بمثابــــة

تغذية عكسية لها ، حتى بمكنهــا اتخــاذ

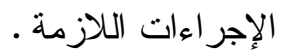

- الاختيار السليم للأشخاص الذين يــؤدون

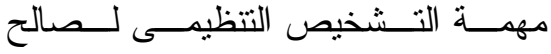

المنظمة ، سو اءً كانو ا من داخل المنظمة

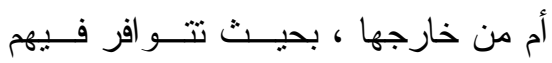

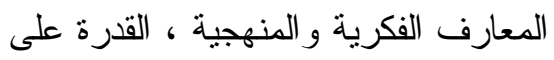

التحاور و الاتصالات مع الجميع وبــدون

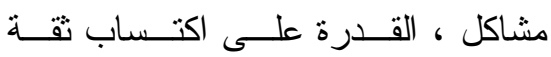

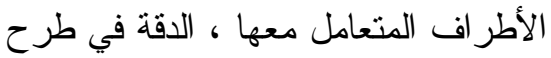

الأسئلة و القدرة على الإحاطة بالإجابات،

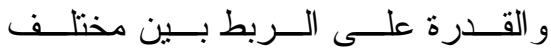

المعلومات وتحليلها بشكل علمى سليخ .

ومن ثم تتعدد وتتتوع متطلبات نجــاح

التشخيص التتظيمى ، ما بين الاختيار الــسليم

للقائمين عليه وتدريبهح بشكل علمى فعـال ،

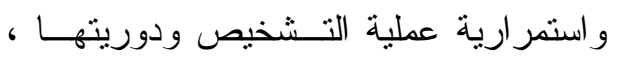

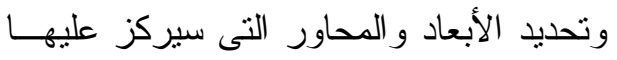

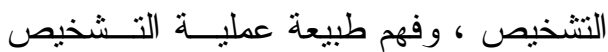

و آلياتها ، إضافة إلى تو افر الإر ادة و الاستعداد

للاستفادة من نتائج التشخيص.

1 - معوقات ومآخذ التثخيص التظيمى :

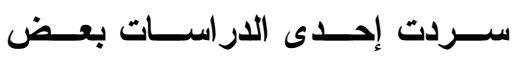

معوقات نجاح التثخيص التظيمى ومنها : 
أ-r - أهمية نماذج التشخيص التنظيمى :

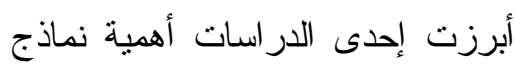
التشخيص التنظيمى فيما يلى :

- تساعد على تصنيف البيانات والأنـشطة وسلوكيات المنظمة.

- تساعد على تعزيز الفهم الجيد للمنظمــة من خلال تشخيص المشاكل التى تتطلب

$$
\text { التصحيح و العلاج. }
$$

- تساعد في توجيه العمل في اتجاه التغيير -

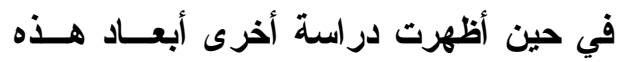
الاهمية فيما يلى : فين اطرت درال

- تحديد المتغيــر ات و الأبعــــاد التتظيميـــة

$$
\text { الحيوية وطبيعة العلاقات بينها. }
$$

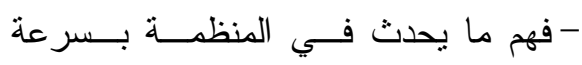

$$
\text { ووضوح. }
$$

- تفسير البيانات و النتائج حول المنظمة.

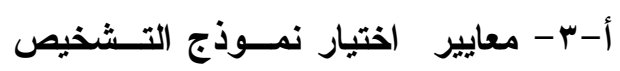
التنظيمى : معايليز

من أهم المعايير التى ينبغى مر اعاتها

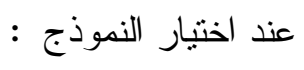

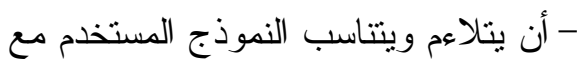

طبيعة المنظمة محل النشخيص ، بحيث

يتسم بالثمول و البساطة و الكفاية وتغطية

$$
\text { الأبعاد الرئيسية. }
$$

- أن تتو افق البيانات التنظيمية مع النموذجن

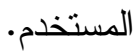

ومن أهـــم معسايير اختيــار نمــاذج

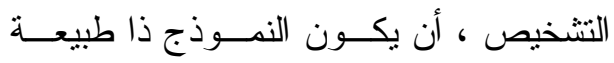

- عدم وضوح المعايير التــى ســيتم فـي ضوئها التشخيص التنظيمى.

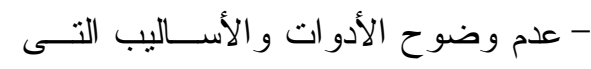
سيتم من خلالها التشخيص التنظيمى.

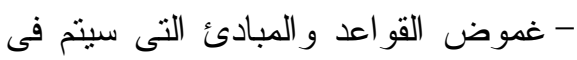
ضونئها التشخيص التنظيمى.

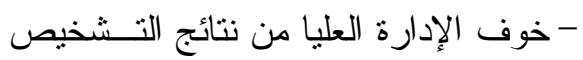

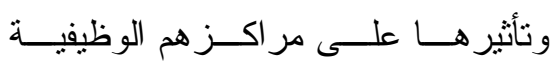
و القيادية.

الخطوة الثانية : نموذج ويسبورد للصناديق الـست للتـشخيص التظظيمسى Six-Box Model

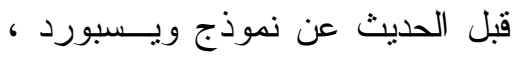
سيتم إعطاء نبذة عامة مختصرة عن نمـاذج

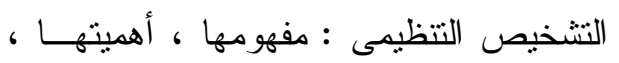

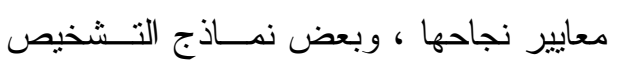

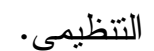
أ-نماذج التشخيص التنظيمى : أ-1 - مفهوم نماذج التشخيص التنظيمى : يعد نموذج التشخيص التتظيمى بمثابة تمثيل مجرد وبأسلوب ملخص لميزات و اقعية

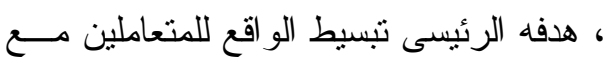

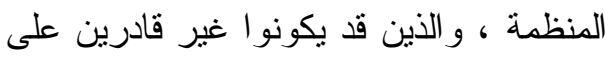

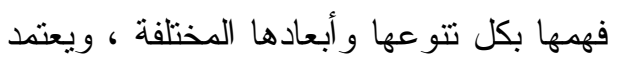
على النموذج كإطار مفاهيمى لفهم المنظمات

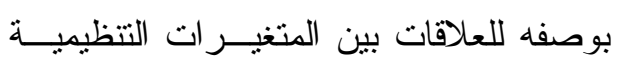
فيها . فو 
نموذج ويسبورد للصناديق أو الأبعاد الـست

للتنخيص التتظيمى 9 197.

ب- نموذج ويسبورد Weisbrd لــــناديق

الست للتشخيص التنظيمـى Six-Box

: Model

سيتم تتاول نموذج ويسبورد على النحــو

التالى :

ب-1 - ماهية نموذج ويسبورد للــصناديق

الست للتشخيص التنظيمى :

هو نموذج للنتخيص التنظيمى أعـده

R Marvin وطوره الباحث مارفان ويسبورد عام $19 V 7$ Weisbord

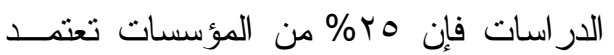
على هذالنموذج لإجر اء التشخيص التنظيمى

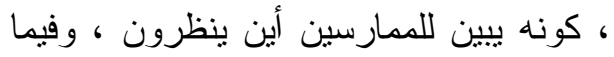

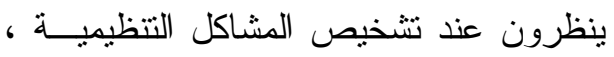
حيث يتضمن عدداً من المكونــات و النقــاط

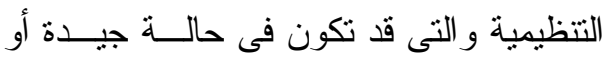

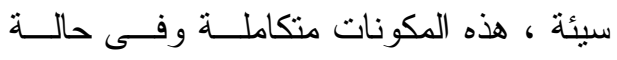

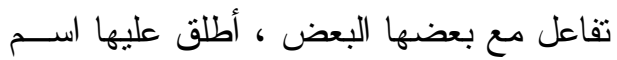
الصناديق الستة .

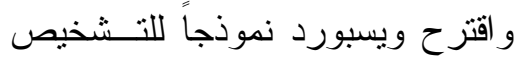

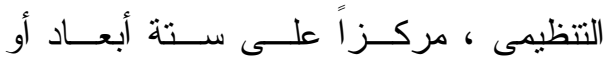

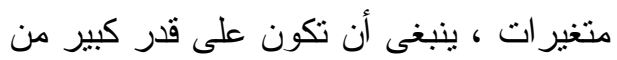

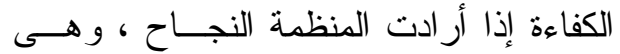

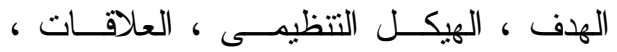

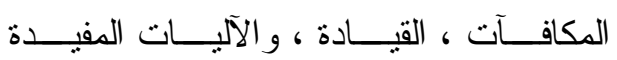

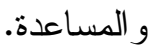

مفهومة وو اضحة وليست معقدة ، وأن يكون

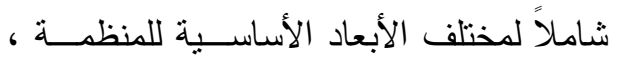

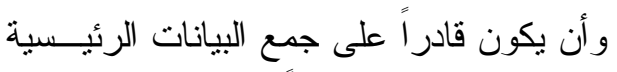

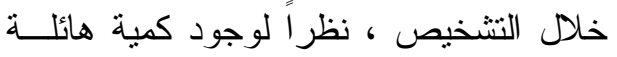
من البيانات المتاحة للتحليل .

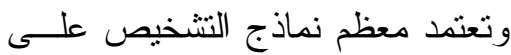

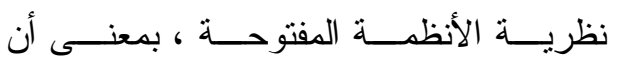

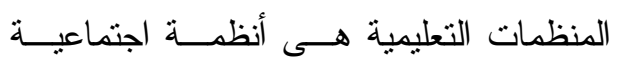

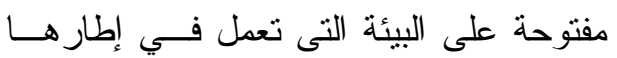
المنظمة ، تؤثر فيها وتتأثز بها. أ- צ - بعض نماذج التثخيص التنظيمى :

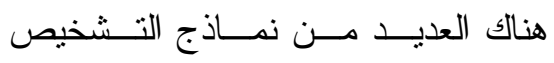
التظظيمى ، منها : لهائر - نموذج تحليل القوة 1901.

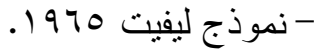
- نموذج الأنظمة المفتوحة 1977 - 1970.

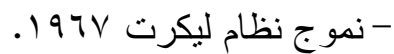

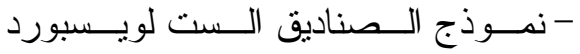
$.19 \vee 7$

- 19VV نموذج التطابق لتحليل المنظمة - نموذج ماكينز 1919 1919 - 191. - نموذج البرمجة عالية الأداء عـ19 1.

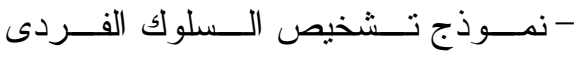

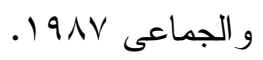

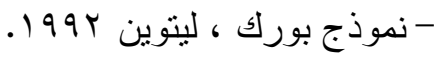

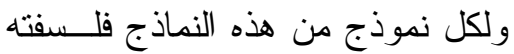
ونظرية الخاصة ، كما اعتمد كل نموذج منها لهاديا

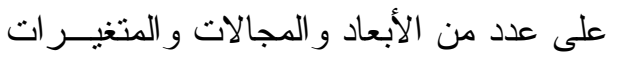

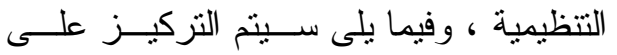


ويوضح الثكل التالى أبعاد التشخيص التظظيمى وفق نموذج ويسبورد للصناديق الست :

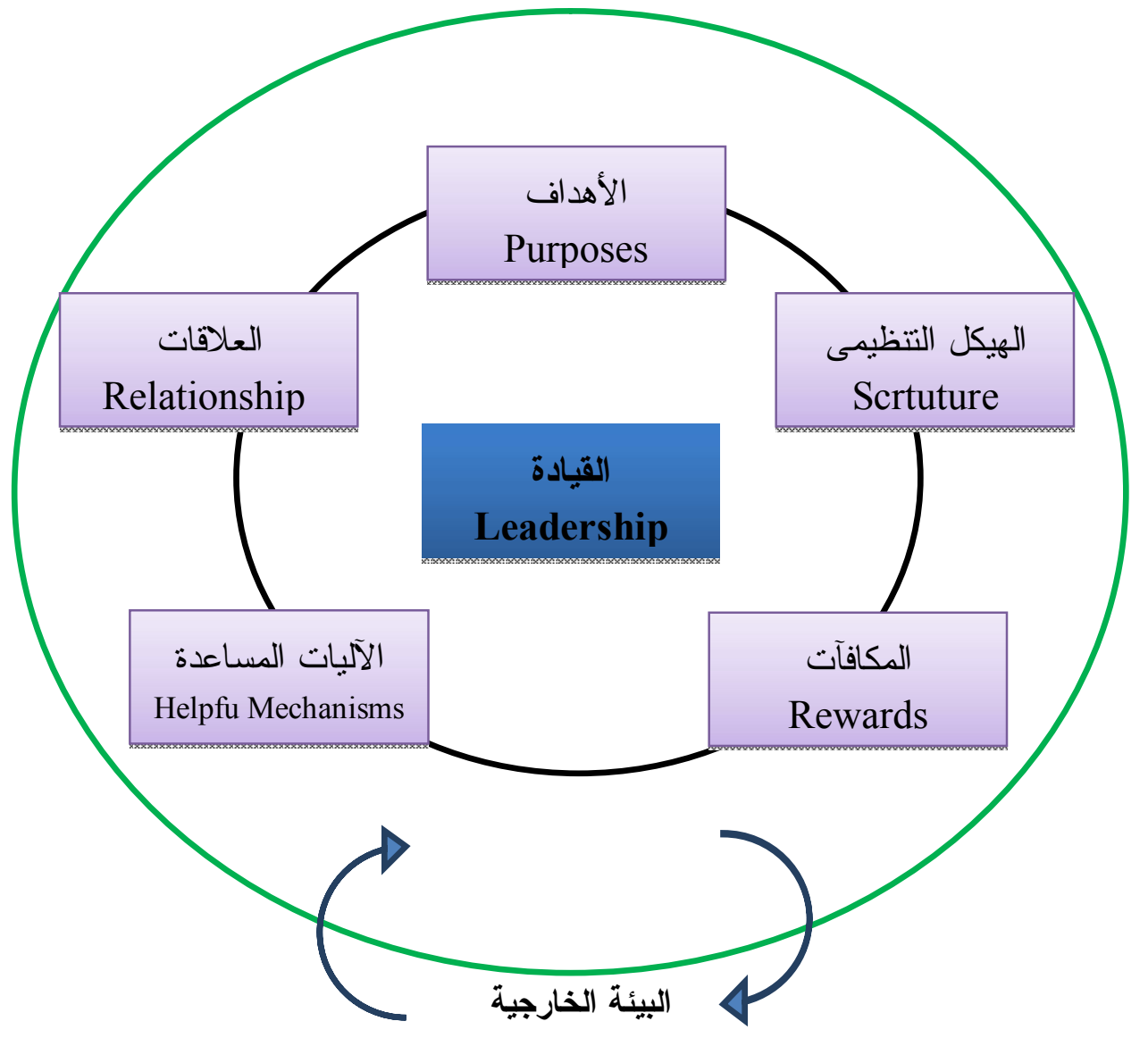

Environment

الثكل (1) نموذج ويسبورد للصناديق الست للتشخيص التنظيسى

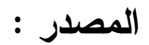

NHS North West Leadership Academy, the Six Box Model, Defining OD, Available at : URL : http://www.nwacademy.nhs.uk/developingtogether/Six-BoxModel,

ووققاً لويسبورد ، من الضرورى فهم الموجودين فى المنظمة ، فهم أقدر من غير هم

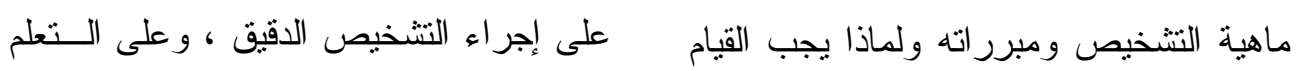

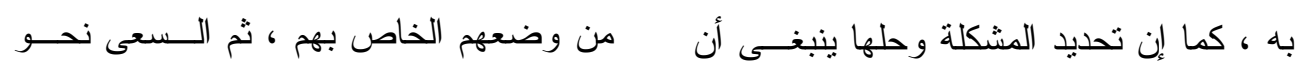

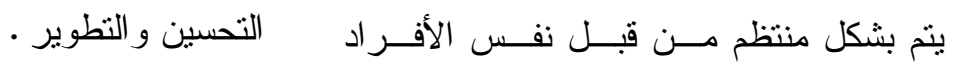


وفرعية يساعد على إجر اء تشخيص نتظيمى

ونموذج ويسبورد يركز على القضايا

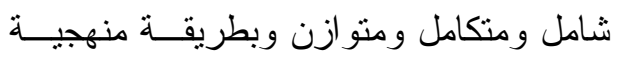
الداخلية داخل المنظمة بشكل أساسى ، عـن لـن طريق طرح أسئلة تشخيصية حددها فى : مال سليمة. وجمعت إحدى الاراسات مزايا هذا النموذج

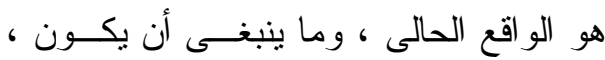

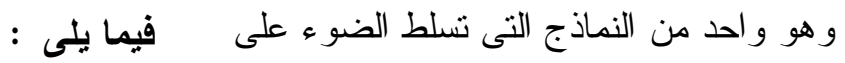
- نموذج لا يحتاج إلى وقت كبير فى عملية

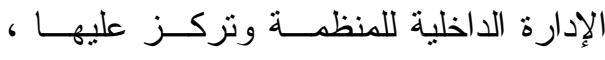

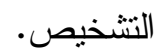

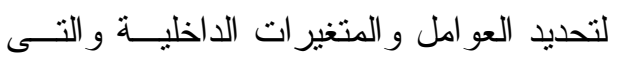
- يتميز بالبساطة و الوضوح و البعــــــن يجب وضعها فى الحسبان لتكييف ممارســات

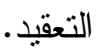

- يعتبر نموذجاً مناسباً للمبندئين فى عملية

$$
\text { التشخيص. }
$$

- يستخدم بمثابة خريطة معرفيـة تـسمح

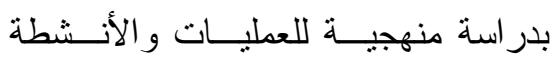
الو اردة فى كل خانة و التحقق من وجــــود

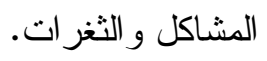

- يستخدم الممارسون هذا النموذج كخريطة لحل المشاكل داخل التتظيم.

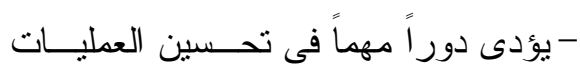

$$
\text { التتظيمية. }
$$

ب-r- أبعاد ومكونات نموذج ويسبورد : يتكون نموذج ويسبورد من ستة أبعاد

$$
\text { رئيسية وهى : }
$$

ب-r-1 - الأهد اف والأغراض Purposes: وينظر اليها ويسـسبورد علــى أنهــا الغايات و الأهداف و المهام الأساسية للمنظمة ، ولئه وهى التى تنين لأفر اد المنظمة ما الذى يجب الاهدانه

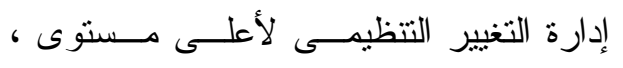
وتحقيق أداء تتظيمى أكثر فعالية . و اقتـــر ح ويسـسبورد أداة تشخيــصية تضمنت (•r) عنصر أ أو مفردة ، تـستخدم

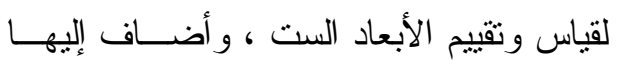
خمسة عناصر أو مفردات أخرى تقيس عاملاً

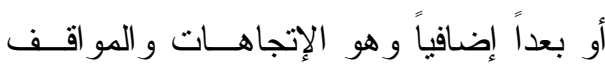

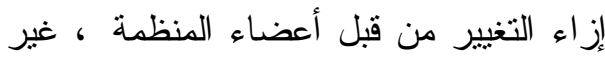

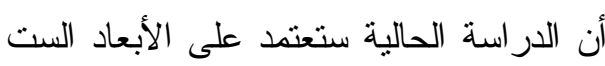

$$
\text { الأساسية لهذا النموذج. }
$$

ب-r- مزايا نموذج ويسبورد للـصناديق الستة : المت

يتميز نموذج ويسسبورد للــصناديق

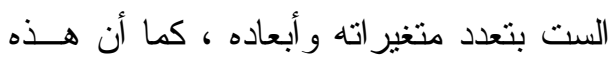
الأبعاد منباينة فى طبيعتها ، فبعضها متماسكة

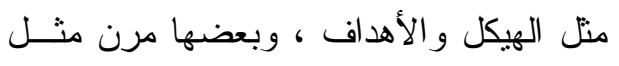
القيادة و العلاقات و المكافآت ، كما أنها أبعـاد ولهاد

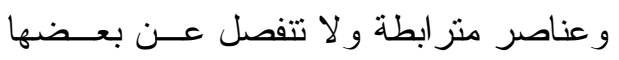

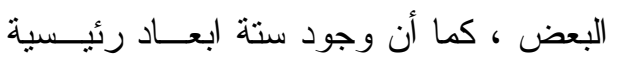


ورسالتها أولاً ، باعتبار أن الرسالة تعد بمثابة

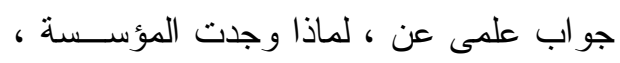

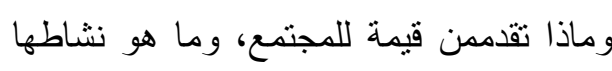

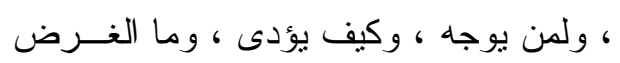

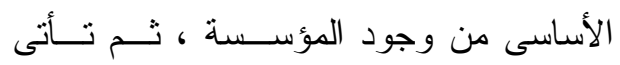

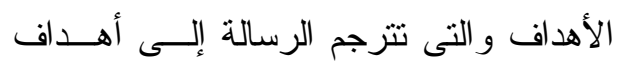

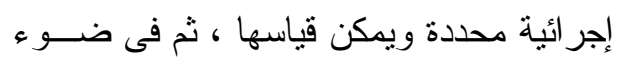

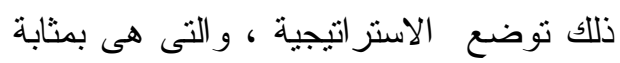

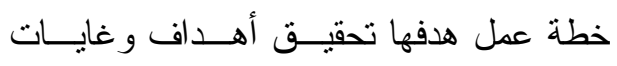

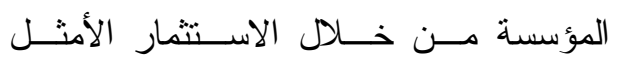
لمو اردها.

ومن الأمور التى تساعد في قيــاس

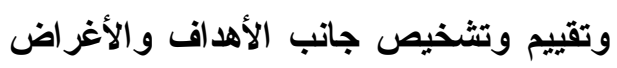
ومدى فاعليتها ما يلى :

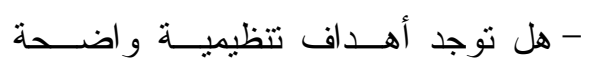
ومحددة ومعلنة للجميع.

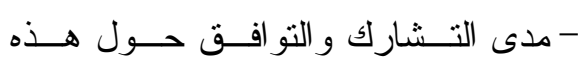

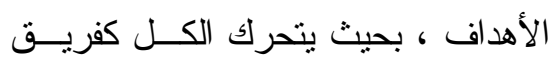

واحد تجاه تحقيقها. - تحديد الآليات و الأســـاليب و التغييــرات

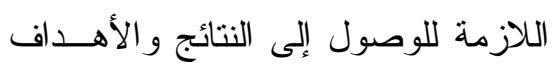
المستقبلية المنشودة. - مدى غموض أو تتاقض أو عدم وضوح الأهداف.

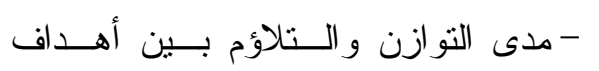
المنظمة و أهداف أفر ادها.
عمله ، وما هى الغايات المنشودة ، وقد تكون الأهداف رئيسية أو ثانوية ، وقد تكون مقيدة الأمد أو طويلة الأمد ، وقد تكون صريحة أو نو ضمنية . و الأهداف و الغايات هى التى نوضــح سبب وجود المنظمة ودو اعى انشائها ومهامها

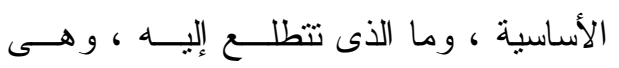

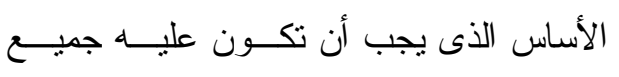
العمليات و الفعاليات و المخرجات و النتائج.

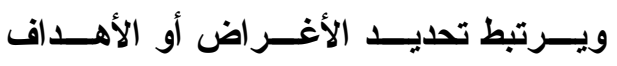
بعنصرين أساسيين هما :

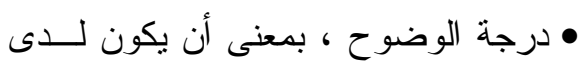

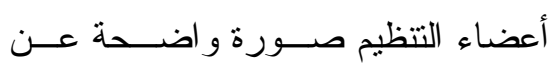
أغر اض و أهداف التنظيم.

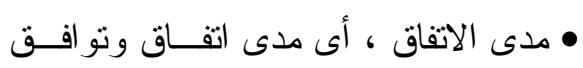
أعضاء التتظيم بشأن هذه الأهداف.

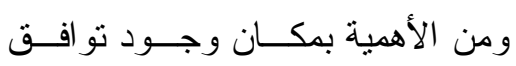

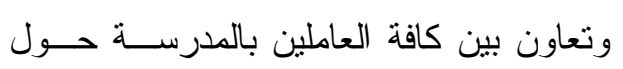

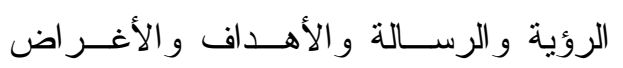
الأساسية ، فهذا التو افق يولد دافعية أكبر نحو ولانية

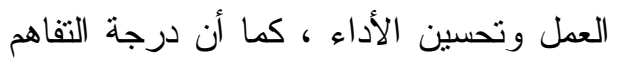

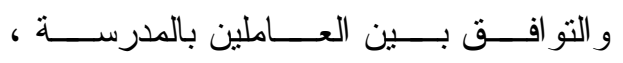

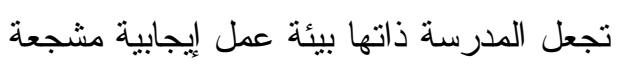

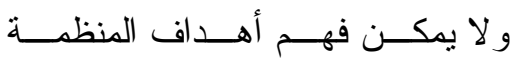
و أغر اضها ومهامها إلا من خلا فهم رؤيتها 
لتحقيق أهداف المنظمة ، وهو حصيلة تفاعل

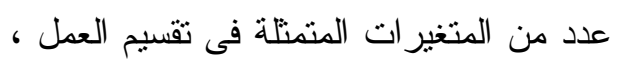

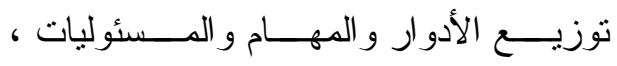

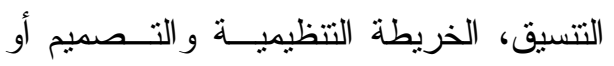
البناء التنظيمى ومستويات الإثر اف.

ويعد الهيكل التتظيمى إطاراً أو بنــاءً

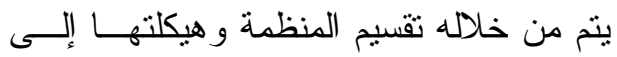

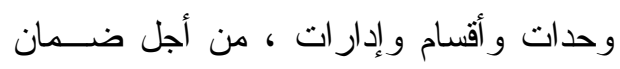

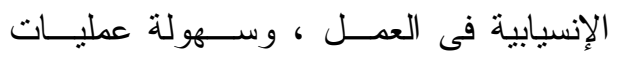
التتسيق والرقابة ، وهو وسيلة لتحقيق أهداف المنظمة .

وبمعنى آخر يعطى الهيكل التتظيمسى صورة مكبرة لمستويات السلطة و المسـئولية و العلاقات الرسمية بين الأفر اد و المجموعات ولترة ولينات و الوحدات الوظيفية فى المنظمة. وليست القضية فــى وجــود الهيكـلـ التتظيمى أوفى مستوياته ودرجاته وتــشكيله وبنيته ، بقدر ما هى فى مدى نجاح الهيكـل ملئل

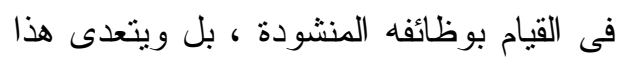
إلى حد الإبداع و الفعالية و التميز .

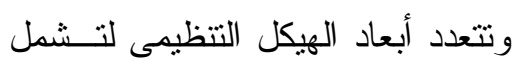

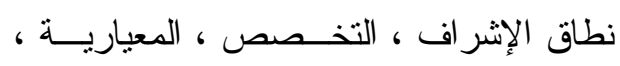

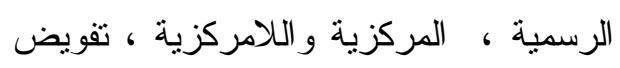

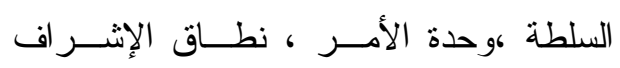

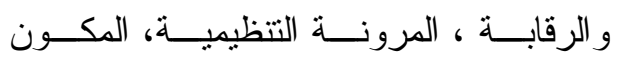

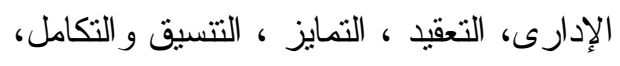

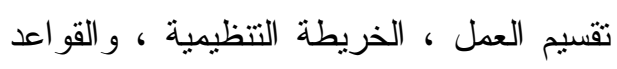

- مدى الوعى بأغر اض و أهداف المنظمة.

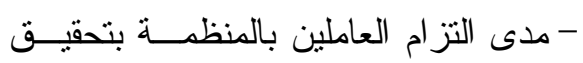
الأهداف.

- مدى الدعم الذى تقدمه إدارة المنظمة في اتجاه تحقيق الأهداف. - التأكد من مدى تو افر المـــوارد اللازمـــة لتحقيق الأهداف التتظيمية.

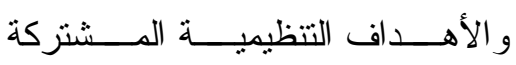
و المتو افق عليها تخلق مو اقف متسقة ومنسجم بين الموظفين ، و الذين سيوجهون قـــــار اتهم

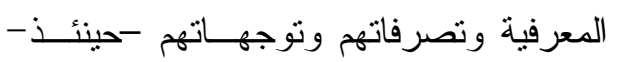

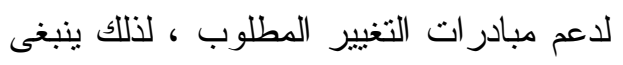

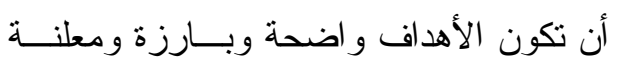
لجميع أعضاء المنظمة . لالهون

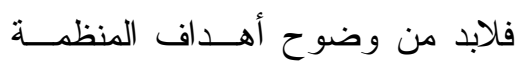
للعاملين كافة ، لأن العاملين إذ لم يكونو العلى اهلى

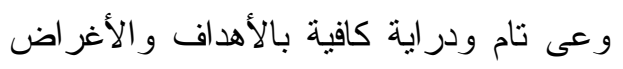

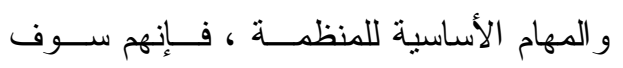

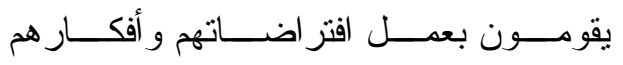

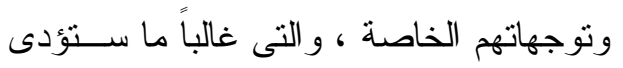
إلى تحقيق نتائج غير مرضية.

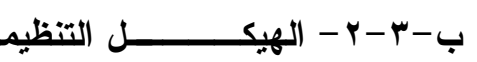

\section{: Organizational Structure}

الهيكل التظيمى نظام رسمى لعلاقات

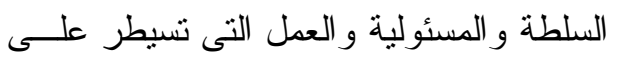
كيفية تتسيق فعاليات الأفر اد و استخدام الموارد 
- الدعم التتظيمى بأثنكاله المختلفة. - التمكين و التفويض الإدارى. - مدى المرونة و الرشاقة التنظيمية. - مدى وضوح قنو ات ووســائط و آليــات

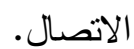

- تخصيص نطاقات ومسـسئوليات الإدارات

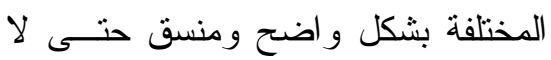

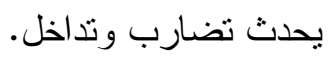

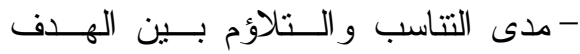
و الهيكل الداخلى للمؤسسة.

- نوع النمط السائد فى الهيكل التنظيـــى : مركزى أو لا مركزى. - مدى وضوح الــسياسات و الإجـــر اءات النتظيمية بالنسبة للعاملين.

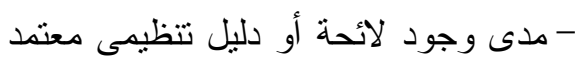

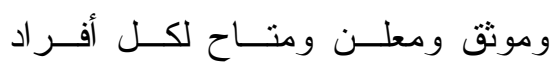

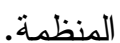

ب-r-rationships ويوضح ويسبورد ثلاثثة أنــواع مــن

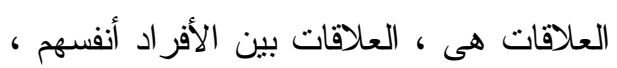
العلاقات بين الوحـــات ، و العلاقــات بــين

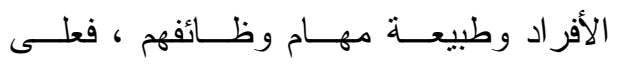
الثخص أن يشخص أولاً مدى تو افر التعاون

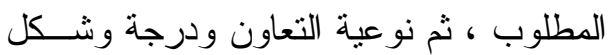
هذه العلاقات ، ثم كيفية إدارة الصر اع داخل ودل ونل التنظيم • هذه
و الإجر اءات الحاكمة. ويضيف إليها الــبعض

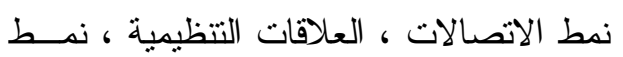

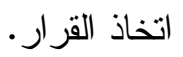

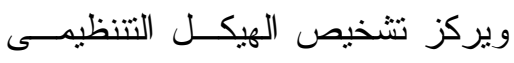
على فحص مدى التو افق بين الأهداف و البناء

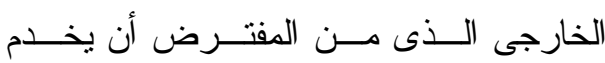
أغر اض التتظيج وبما يحقق الفعالية التتظيمية،

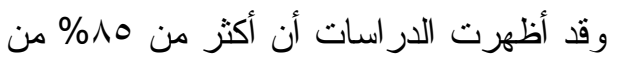
مصادر المشاكل التنظيمية ، تعود إلى الهيكل التتظيمى و الأنظمة و الثقافة التتظيمية الــسائدة فى المؤسسات .

ويجب أن يتضمن تثخيص الهيكل التظيمى النقاط التالية :

- مدى وضوح الهيكل و البنيـــة التنظيميــة

$$
\text { و انعكاس ذلك على أداء الأعمال. }
$$

$$
\text { - مـــدى وضــــوح مـــستويات الــسلطة }
$$

- مدى السلط الممنوحة للأفر اد للمـشاركة

$$
\text { فى إدارة المؤسسة. }
$$

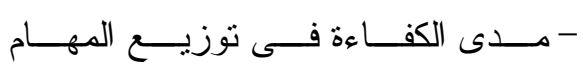

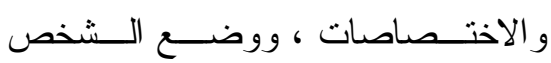
المناسب فى المكان المناسب.

- مدى التوازن و التكــافؤ بـين الـسلطة

$$
\text { و المسئولية. }
$$

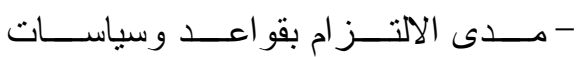

$$
\text { و إجر اءات المنظمة أو انتهاكها. }
$$

- أسلوب صنع القرار داخل المنظمة. 


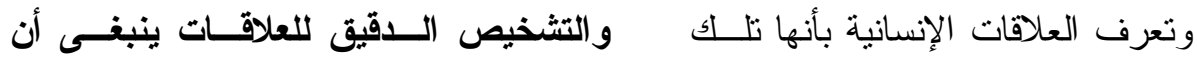

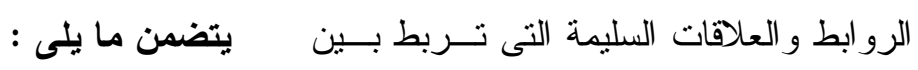

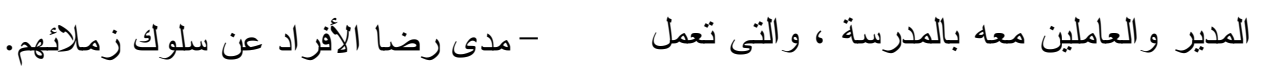

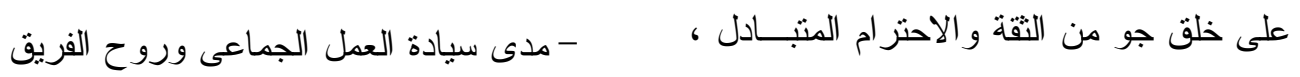
وتهذف إلى رفع الروح المعنويسـة للعـاملين والنشاطات المشتركة.

- مدى وجود الصر اعات داخل المنظمــة

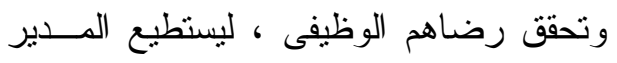
و أساليب التغلب عليها. - مدى سيادة الانسجام و الوحدة و التتـــاغم

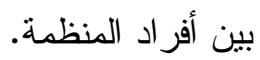
- درجة ومستوى الحوار و التواصل بــين

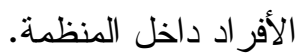

- مدى سيادة العلاقات الإنسانية الحقيقيــة

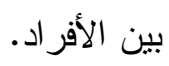

- مدى سيادة الثقـــة و الــشفافية و الــصدق

$$
\text { و الاحتز ام المتبادل. }
$$

- مدى تتاغم العلاقات بين الأفر اد و الإدارة

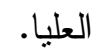

- مدى جودة العلاقات بين المنظمة وبيئتها

$$
\text { التى تعمل فيها. }
$$

- مدى الشعور بالارنياح النفسى و الرضــــا

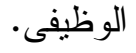

ب-r- Rewards يعرف التحفيـز علــى أنـــهـ تـشجيع تحقيق معايير الإدارة الفعالة. وهى مجموعة العلاقات المنبادلة بين

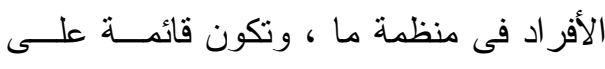

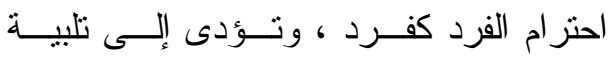

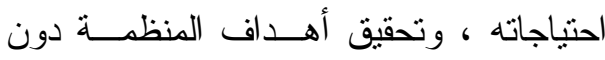

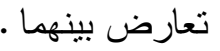
وينبع الاهتمام بالعلاقــات الإنـسانية

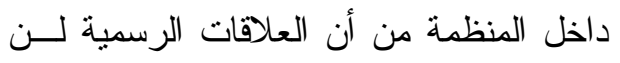
تحقق وحدها كافة الأهداف التتظيميــة ، و أن كثير أمن الأعمال تتجز من خـــلال العـاملين

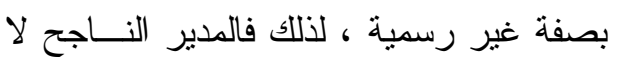

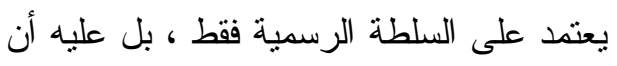
يسعى لفهم التتظيمات غير الرســـية أيــضاً ويحسن التعامل معها و استثمار ها بشكل فعال

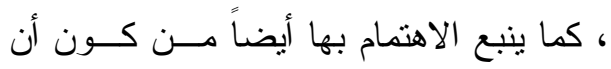

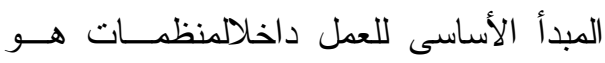

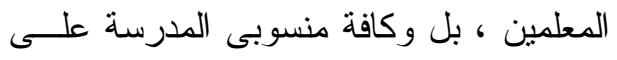
أداء مهامهم الوظيفية بطريقة أفضل من خلال العمل الجماعى أو العمل بروح الفريق ، مما لمان يستدعى ضرورة الاهتمام بالعلاقـات بـين بــين

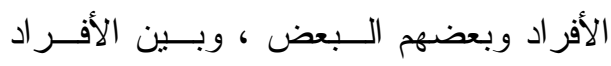

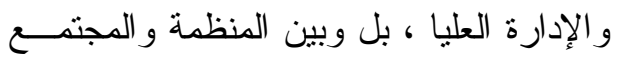

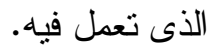


حسب طبيعة الأطر اف المستقيدة منهـــا إلــى حو افز فردية و أخرى جماعية .

وينبفى أن يتضمن التشخيص الاقيق والفعال

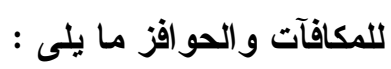
- مدى رضا العاملين عما يقدم لهــم مـن

$$
\text { مكافآت وحو افز . مدافي }
$$

- مدى عدالة وموضوعية نظام المكافــآت

$$
\text { و الحو افز • مدى عد }
$$

- مدى كفاية الحو افز و البدلات و المكافــآت

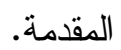

- مدى شمول ونتوع الحو افز ما بين حو افز

$$
\text { معنوية ومالية ومادية. }
$$

- مدى تتوع وشمول الحوافز ما بين حوافز

$$
\text { إيجابيةو أخرى سلبية. }
$$

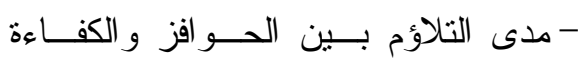

$$
\text { الحقيقية. }
$$

- مدى التلاؤم بين المــسئوليات و المهـــام

$$
\text { ونظام المرتبات و الأجور • }
$$

- مدى تقييم الأفر اد فــى ضــــو ه معــايير

$$
\text { موضو عية. }
$$

- هل نظــام الترقــى مــــنبط بالإنتاجيـــة

$$
\text { و الكفاءة. }
$$

- مدى سيادة العلاقات الإيجابية بين الإدارة

$$
\text { و العاملين. }
$$

- هل يتم توفير بيئة وظروف عمل مناسبة

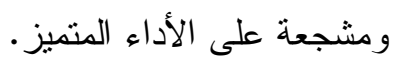

تقديم الحوافز المادية والمعنوية لهم ، وبمــا يؤدى إلى تحريك دو افعهم و إثباع حاجاتهم .

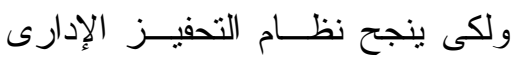

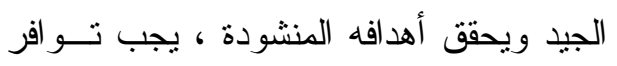
عدة شروط منها : - أن ترنكز الحوافز على معايير وأسـس لتس عادلة ومقبولة.

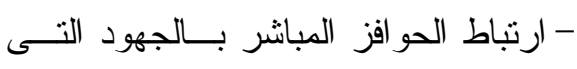
تبذل أثناء أداء العمل ، سو اءٌ كان جهــــاً ذهنياً أو بدنياً. - أن تصرف الحو افز و المكافـآت بـشـل

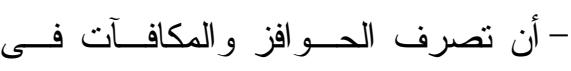
مو اعيد متقاربة ومحددة.

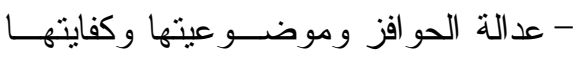
ومعياريتها. - أن تشتتد الحوافز إلى سياسة أو فلــــفة تحكمها وتطبق على الجميع.

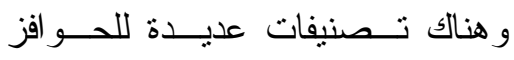

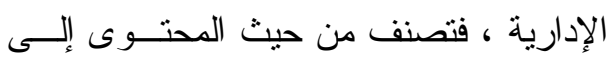

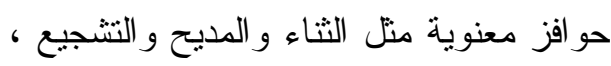

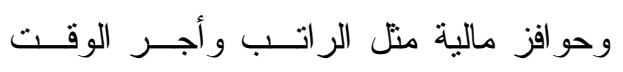

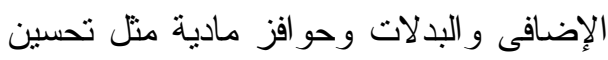

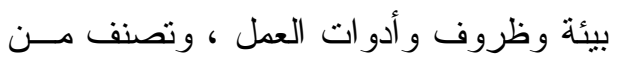

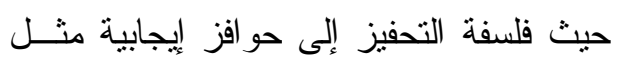
النتجيع و الإثابة ، و أخرى سلبية منل العقاب

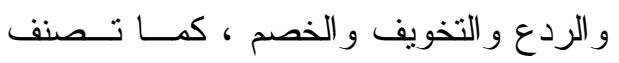


لتقبله ، القدرة على التأمل الذاتى للممارســات

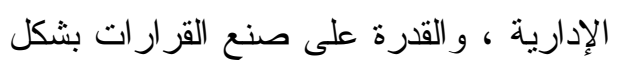
جماعى نتاركى .

والتشخيص الجيد والاقيق لمحور القيــادة ، ينبغى أن يتضمن ما يلى :

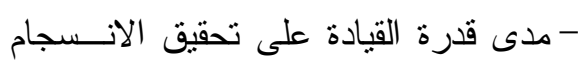
و التوازن بين مختلف أبعاد المنظمة.

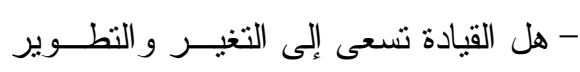
وتحسن إدارته. - هل تعمل القيادة فى إطار نموذج قيمسى أخلاقى و اضح.

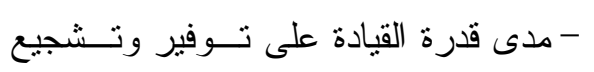
فرص التتمية المهنية المستدامة للعاملين. - مدى قدرة القيادة على التوجيه و الإرشاد و التأثنير فى الآخرين.

- مدى نجاح القيادة فى تشجيع الأفر اد على الى

$$
\text { المشاركة فى صنع القرار . }
$$

- هل تمتلك القبــادة رؤيسـة اســتز اتيجية و اضحة لقبادة المؤسسة.

- مدى قدرة القيادة على تقديم الدعم الكافى لجهود العاملين.

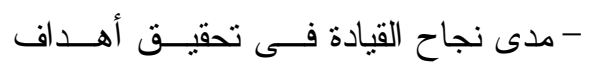
المنظمة. - تتطلق القيادة من معايير وضو ابط تطبق على الجميع بموضو عية وعدالة.
- مدى شعور العاملين بالدف و الارتيــاح النفسى تجاه سياسة الحو افز و المكافآت.

ب-r-Leadership القيادة

وتتعرف القيادة على أنها القدرة علــى

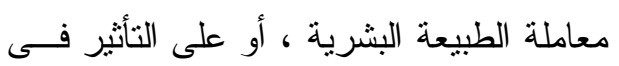

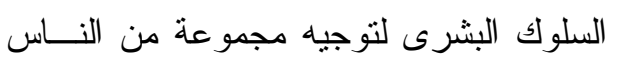
نحو هدف مشترك بطريقة تعمل على اكتساب

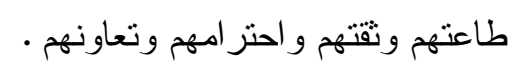

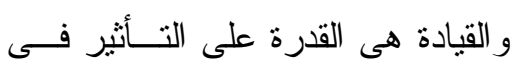

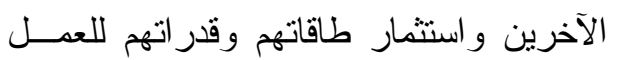

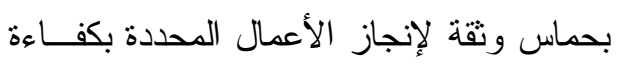
وفعالية. و القيادة نشاط حقيقى وجوهرى بــين

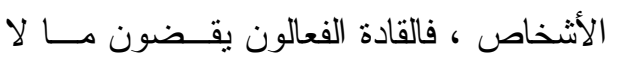

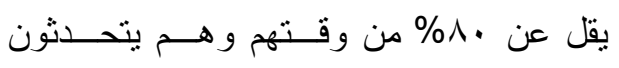

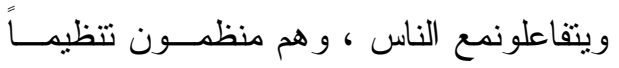

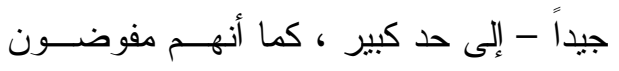
جيداً . وأظهرت الأبحاث أن القيادة الفعالـــة

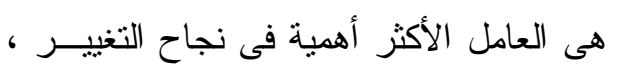

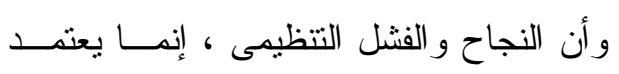
على قدر ات قيادة المنظمة . ومن أهم القدرات التى ينبغى تو افرها

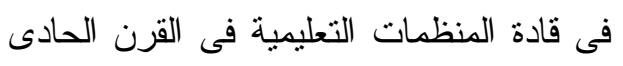

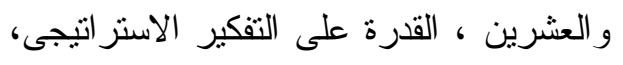

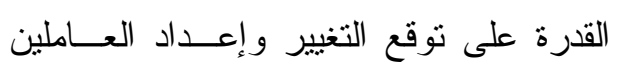


وهى الأنظمة و الآليات التى تسهم فى ألى

تحقيق أهداف النطوير منها ، المساهمة فــى ولنى

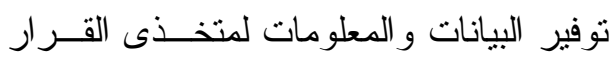

بصورة مستمرة ودون تشويش ، تشجيع روح

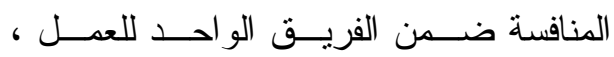

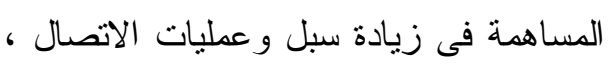

ومساعدة العاملين على فرص التتمية المهنية،

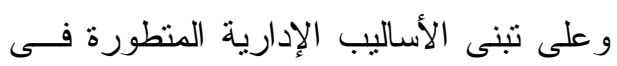

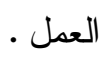

\section{والتشخيص الجيا والاقيق لمحور الآليــات}

المساعدة ، ينبغى أن يتضمن :

- مدى وجود دليـلـل و اضـــح للـــياسات

$$
\text { و الإجر اءات وقو اعد العمل. }
$$

- تتظيم اجتماعات تشجع على التغيير -

- إقامة ندوات ولقاءات وورش عمل نتجع

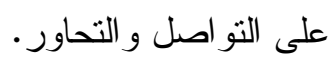

- مدى تشجيع ودعم القيادة للعاملين علــى

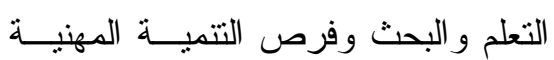

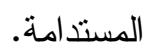

- مدى سيادة ونشر ثقافة تتظيمية تـشجع

على الأداء المتميز و الكفاءة و الفعالية.

- مــدى القــدرة علــى تـــوفير البيانــات

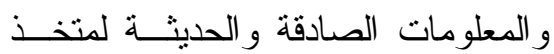

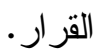

- مدى القدرة على تشجيع العمــل بــروح

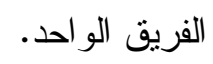

- مدى امتلاك القيادة لمهــار ات الاتــصال

$$
\text { و التو اصل الفعال. }
$$

- مدى قدرة القيادة علــى اتخــاذ القــرار

الرشيد الصائب فى الوقت المناسب وبلا

$$
\text { تزردد. }
$$

- مدى مساعدة ونجاح النمط القيادى الذى

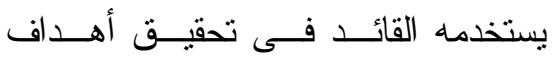

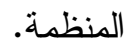

ب-r-צ- - الآليــات المــسـاعدة و المفيــدة

\section{: Helpful Mechanisms}

تعد الآليات المساعدة الخطوات التـى

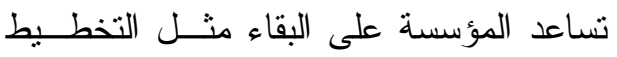

و الرقابة و الميز انية ونظم المعلومات و أساليب

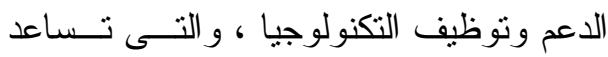

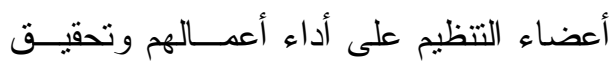
أهداف التتظيم اعضاء النظيم

وهى الأمور التى يمكن أن تساعد أو

تعوق انجاز الأهداف التتظيميــة وتــشمل :

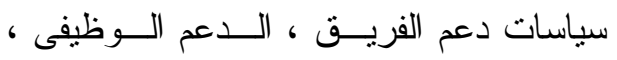

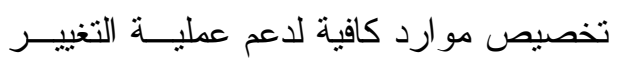

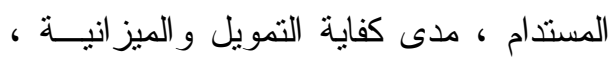

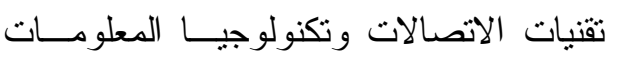

ومدى توظيفها ، الأنظمة المرنة ، التـدريب

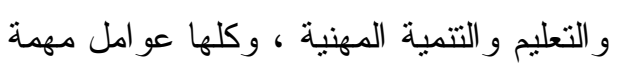
للغاية فى تحقيق التغيير الناجح • 
وفى كل بعد من الأبعاد الست ، سيتم عرض ما يلى : وصى : - بعض الجهود و المبادرات المصرية فـى إطار تحقيق هذا البعد بالمدرسة الثانويــة

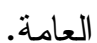
- بعض السلبيات وأوجه القصور المرتبطة بهذا البعد أو المحسـور فــى المدرســـة الثانوية العامة. 1-الأهداف : وسيتم تتاولها على النحو التالى : 1 - 1 - بعض الجهود والمبادرات المــصرية فى هذا المحور : يهذف التعليم الثانوى فى مصر إلـى لـى

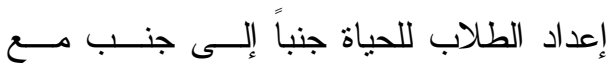

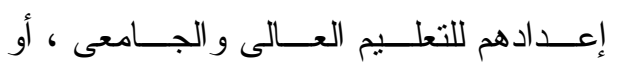

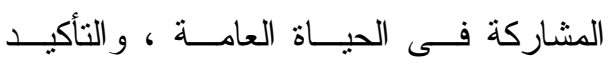
على ترسيخ القيم الدينية و السلوكية و القومية . وقد صممت وزارة التزبية و التعلــيم

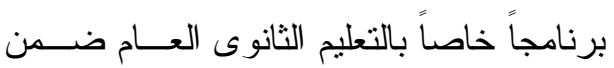

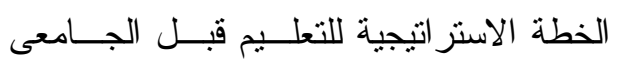

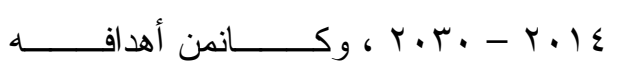
الاستر اتيجية :

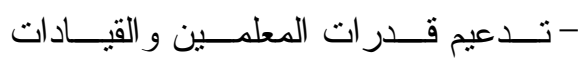

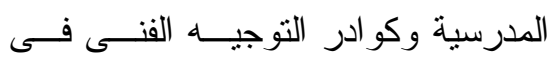

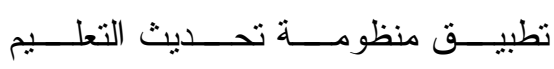
الثانوى.
- مدى القــدرة علــى توظيــــ تقنتــات

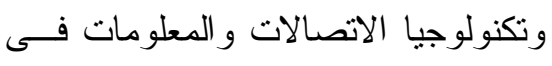
إدارة المنظمة وتحقيق أهـــافها بــشكل ولهعل

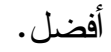
- مدى وجود أنظمة تقتيــة وتكنولوجيـــة عالية الكفاءة. - مدى تو افر سبل و آليات وقنوات الاتصال

$$
\text { الفعال الهادف. }
$$

- مدى مـساعدة العساملين علـى تبنـى الأساليب الإدارية المنطورة.

- أثنكال الدعم الوظيفى الذى تقدمه الإدارة

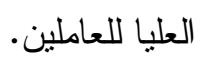

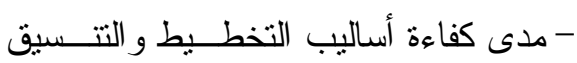
و المتابعة داخل المنظمة.

- مدى كفاية الميز انية الممنوحسـة لتحقيـق

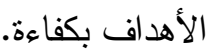
- مدى انفتاح المدرسة كمنظمة على البيئة المحيطة بها.

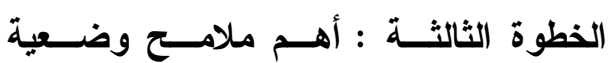
التشخيص التنظيمسى بالمدرســـة الثانويـــة

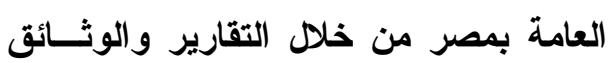
والدر اسات السابقة : ســـتم تتـــاول وضـــية التـشخيص التتظيمى للمدرسة الثانوية العامة بمصر مــن خلال نفس المحاور و الأبعاد الست الرئيــسية لعنية

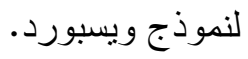




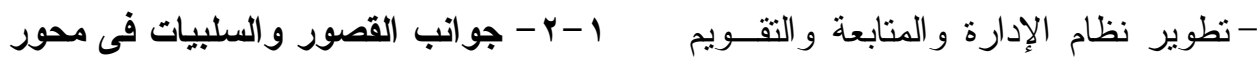

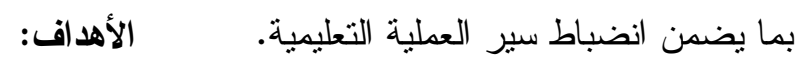

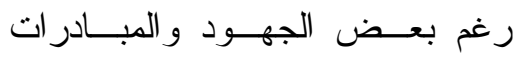
- تحسين جودة الحياة المدرســية لطــلاب

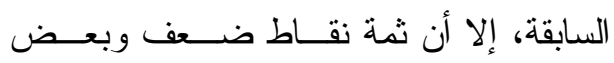
التعليم الثانوى. السلبيات فى هذا المحور ، من أهمها :

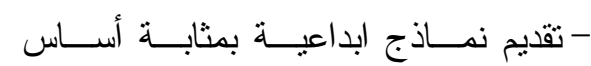

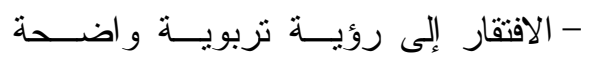

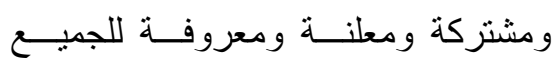

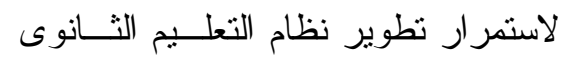
ومرتكزة على الطالب باعتباره محسـور ومئه العملية التربوية .

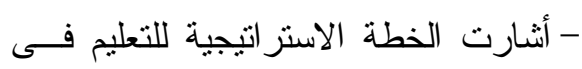

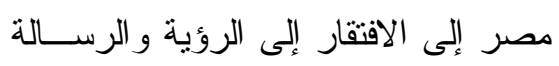

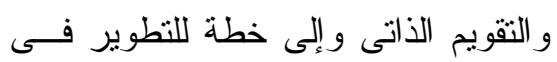
كل مدرسة .

- لا تولى إدارة المدرسة الثانوية اهتمامسـاً و اضحاً بتوضيح الأهداف الاســنز اتيجية للمدرسة .

- ضعف رؤية المدرسة و أهدافها فى سياق

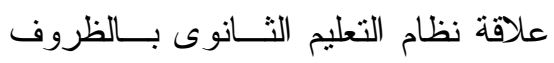
و المتطلبـــات الاجتماعبــــة و الــــياسية

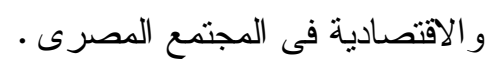

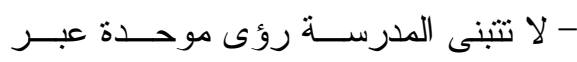

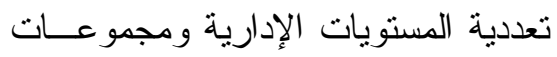
فرق العمل ، إضـافة إلى فقــدان الإدارة

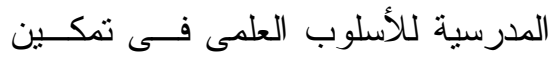

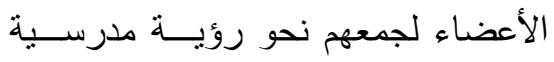
مهنية مشتركة . العام.

وقد أكدت وثثيقــة المعــيير القوميـــة

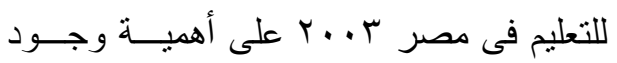

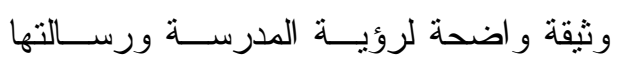

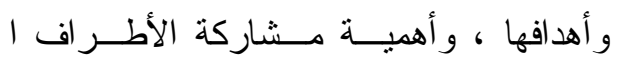

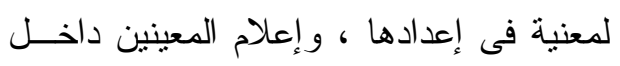
المدرسة وخارجها بالوثيقة ، وكذلك أكـدت واعدات

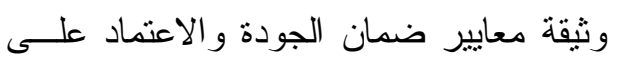

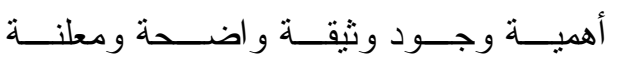

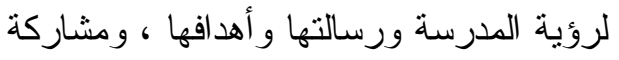

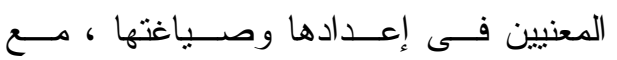

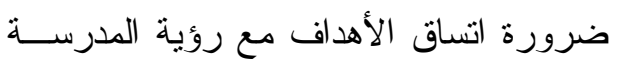

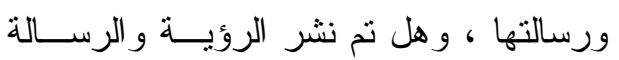

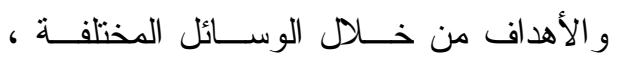

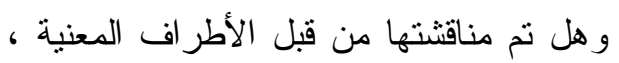

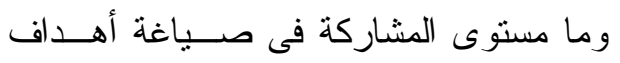
المدرسة ، وهل تم نشر الأهداف الاستر اتيجية

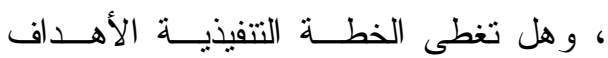

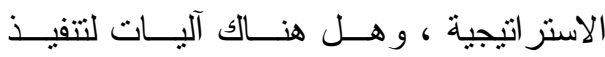

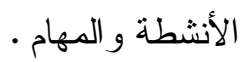




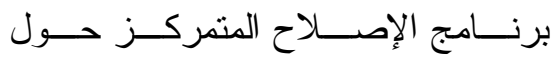
المدرسة ، و إنشاء مجالس الأمناء فى كل لرن المدارس الثانوية ، و إعطاء صـــلاحيات أكبر للإدارة المدرسية من خلال تــدعيم

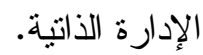

- معايير ومؤشرات وثثقة الاعتماد بالهيئة

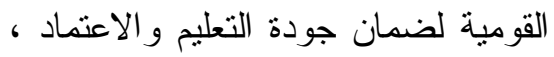
حيث كان الهيكل التنظيمى أحد المحاور و المجالات الأساسية للقــدرة المؤسـسية لهـية بالوثيقة .

r-r - أوجه القصور ونقاط الضعف فى هذا المحور :

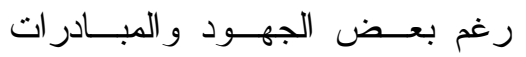
السابقة، إلا أنه ثمة العديد من السلبيات ونقاط الضعف فى هذا الثأن منها :

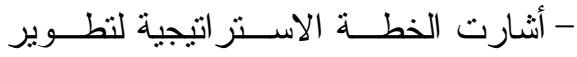

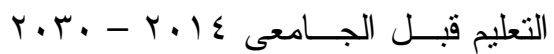
إلى ضعف كفاءة البنى التنظيمية لأجهزة

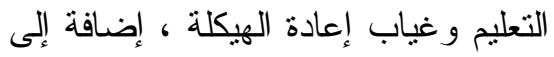
ضــــف تطبيــق سياســات المركزيـــة و اللامركزية ، وضعف نظم الاتصالات

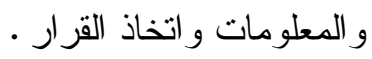

- جمود البناء التنظيمسى بمــا لا بـسمح بمو اجهة التغير ات بالمدرسة ، إضافة إلى لى لاهل

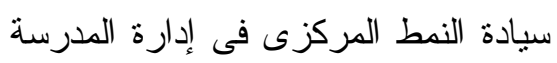

- تتسم معظم المدارس الثانويــة بوجــود درجة من الضعف فى مشاركة العاملين

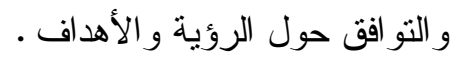
ب-الهيكل التنظيمى : وسيتم تتاوله على النحو التالى : r - 1 - بعض الجهود و المبادر ات المــصرية فى تطوير الهيكل التنظيمـى بالمدرســة الثانوية العامة :

$$
\text { من هذه المبادر ات ما يلى : }
$$

- برنامج نطوير البنية المؤسسية لمنظومة قطاع التعليم قبل الجــامعى فــى إطــار مركزى / لامركزى ، ويهدف إلى تدعيم بنية مؤسسية مركزية /لامركزية توازن ولدردي بين صلاحيات الجهاز المركزى لقطـــاع

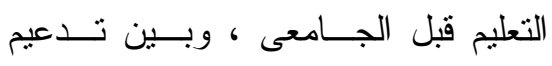

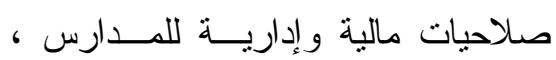

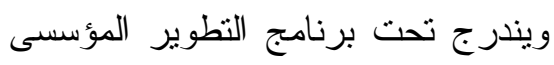

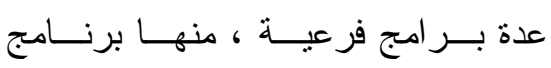

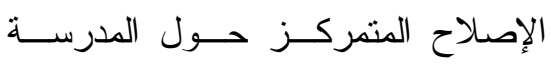

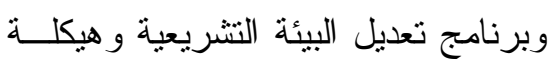

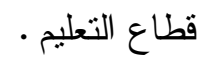
- قدمت وز ارة التربيـــة و التعلــيم بعـــ

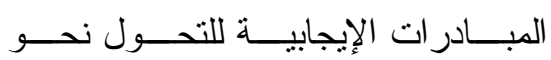
اللامركزية ، سواءً من خلا المعسايير

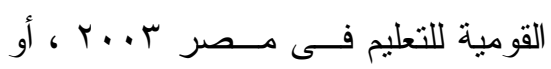

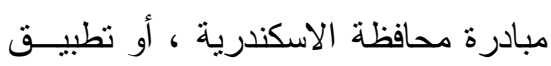


عدم وجود لائحة مدرسية توضح الثواب

و العقاب وطرق ونظم العمل بالمدرسة .

- نشتت الجهود المبذولة من قبل الإدارات

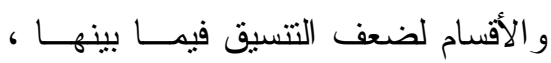

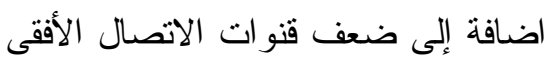

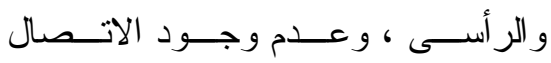

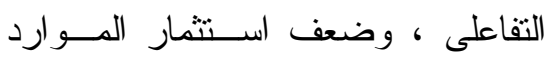

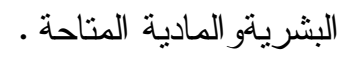

- يعانى التعليم قبل الجامعى عامة و الثانوى

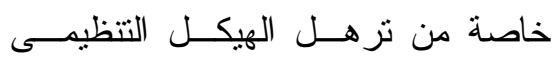

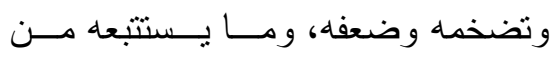

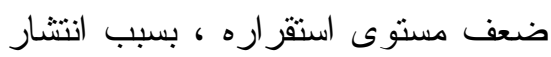

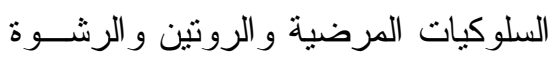

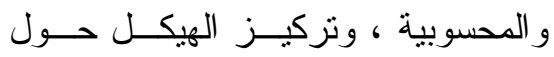

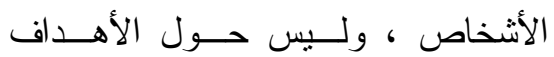
و الوظائف ، مما أدى إلى التسلط و التحكم وغياب الموضوعية بدرجة كبيرة . - تعانى المدارس الثانوية من تسلط النظام المركزى و الذى يضعف الإبداع ، ويقلل

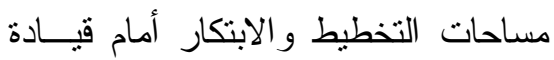

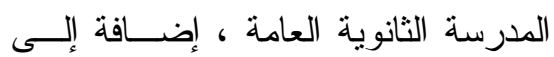

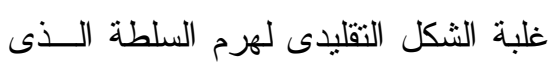

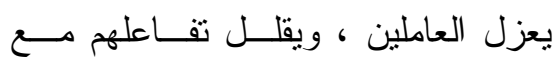

$$
\text { قيادات المدرسة . }
$$

- ضعف وجود قطاع إدارى ومالى داعـــ للامركزية فى المدرسة يربط الموازنـــة بالأداء ، بما يسهم فى تطوير الأسـاليب
الثانوية ، يؤدى إلى عرقلـــة الاســتجابة

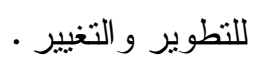

- سيادة ثقافة المركزيــة علــى مـسـتوى

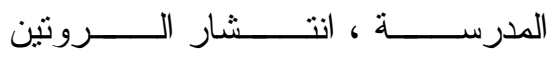
و البيروقر اطية، سيادة النمط الأوتوقر اطى لدي فى إدارة المدارس الثانوية، ميـلـل عــد

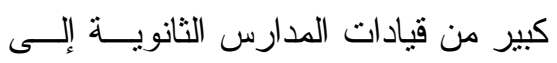

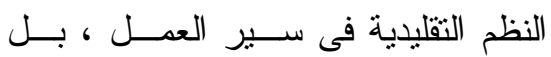
ويقاومون التغيير و التطوير فى مدارسهر

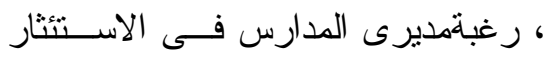
بعملية صنع القرار ، إضافة إلى إخفــاق القان

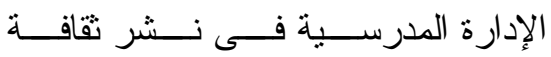
اللامركزية وتفعيلها داخل المدرسة . - ضعف مشاركة الأطر اف المعنيــة فـى

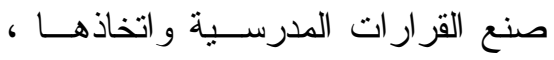
بسبب جمود البنية التنظيمية للمدرســة ،

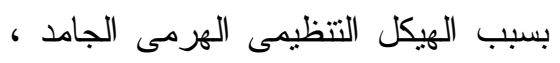

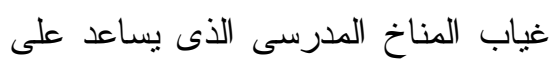

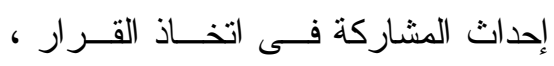
غياب نقافة المشاركة ، و وعـدم إيمــان بعض القيـادات المدرســية بمـشـاركة العــاملين فــى صـــناع القـــر ار و إدارة المدرسة .

- أثنتت احدى الدر اســات الميدانيــة قلــــة الصلاحيات الممنوحة لإدارة المدرسة ، لفرل ضعف مهار ات تفويض الـسلطة لــدى مديرى المدارس الثانوية ، اضافة إلــى لـى لـص 


$$
\begin{aligned}
& \text { بإدارة المدرسة ، وطرح مقترحـاتهم }
\end{aligned}
$$

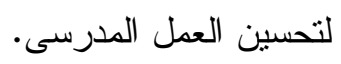

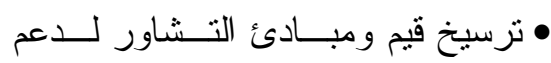

$$
\begin{aligned}
& \text { العمل الفريقى. } \\
& \text { • تحفيز العمــل الجمــــى التعــاونى ، }
\end{aligned}
$$

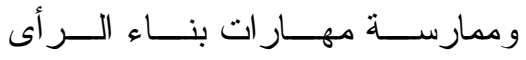

$$
\begin{aligned}
& \text { الجماعى. }
\end{aligned}
$$

وهذا يشير إلى اهتمام الوزارة علــى

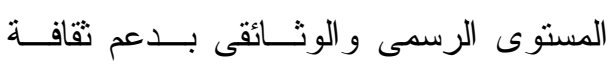

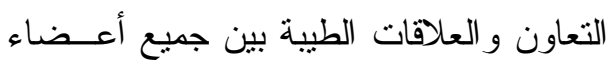

المجتمع المدرسى و المجتمع المحلى ، و العمل

الفريقى الذى يتيح فرص التعــاون و الحــــوار وتبادل الآر اء و الأفكار .

- انثاء مجالس الأمناء و الآباء و المعلمــين

بكل مدرسة ثانوية ، لتؤدى دوراً فعـالاً

فى توثيق الصلات و العلاقات بين الآباء

و المعلمين و إدارة المدرسة فى جو يسوده

$$
\text { الاحتر ام المتبادل . }
$$

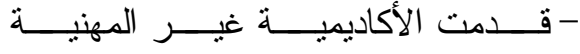

للمعلمين برنامج مهار ات فـرق العدـلـل

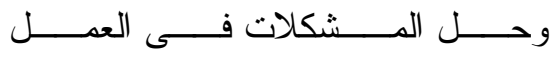

الإدارى ، ويركز ها البرنامج على تتمية

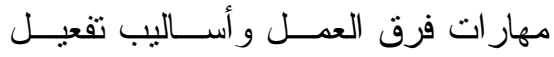

فرق العمل و إدارتها وحـلـ المــشكلات

$$
\text { كفريق }
$$

و الممارسات القيادية المتبعة بالمـــارس بشكل عام - مان

فرغم التوجه الرسمى أو الوثائقى نحو

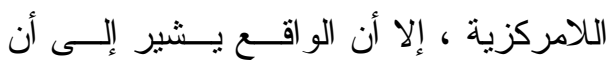
وزارة التربية و التعليم لا تز ال هى صـــاحبة لهـية الر أى الأول و الأخير فى معظم الــــلاحيات

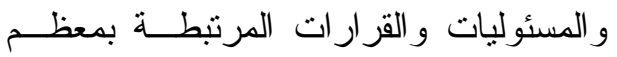

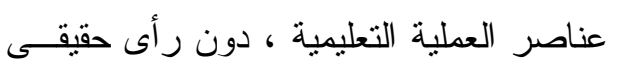
يذكر لمدير المدرسة الثانوية أو معلميها. - ضعف الهيكل التتظيمـى الــذى يحــد

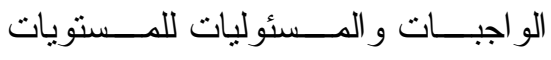

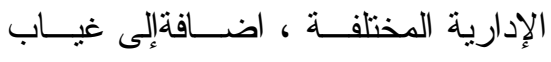
التتسيق و التكامل بين الإدار ات المختلفة . ب-العلاقات : ويتم تتاول هذا المحور كما يلى : ب - 1 - بعض الجهود والمبادرات المــصرية فى محور العلاقات بالمدرسة الثانوية العامة:

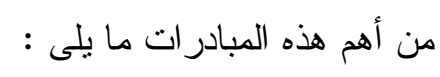

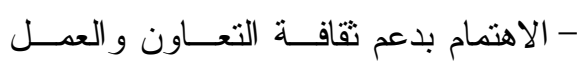
الفريقى من خلال معــيير ومؤشـــرات

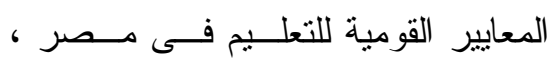
: منها • اتسام العمل فى المدرســة بالتعــاون

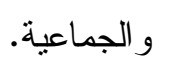
• تعاون الأسرة مع المدرسة من خــلدل

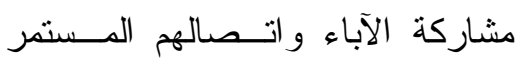


- الافتقار إلى الثقة المنبادلة بين أعـضاء المجتمع المدرسى ، الأمر الذى أثر سلباً

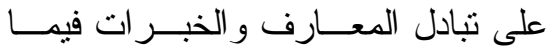
بينهم.

- سلبية المناخ المدرسى ، حيث لا يـسود قيم العمل بروح الفريق القائم على الرؤية

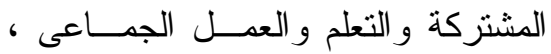
وضعف مستوى التعــاون القـائم بـين ولين

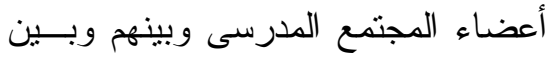
المجتمع المحلى ، وكذللك بين المعلمــين و أولياء الأمور .

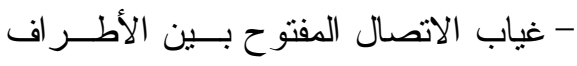

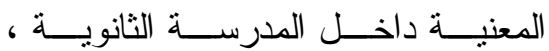
اضافة إلى ضـــف جو انــب الاتــصال المفتوح بين مختلف المستويات التنظيمية

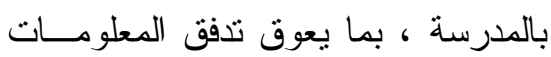
و الخبر ات و الأفكار بين جميع العاملين . - ضعف اهتمام إدارة المدرســة الثانويــة بإيجاد مناخ إيجابى يشجع على الدئ التعلــيم

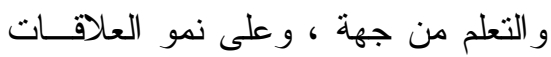
الإنسانية داخل المدرسة من جهة أخرى . ع -المكافآت والحوافز :

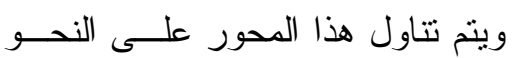
التالى :

ع - 1 - بعض الجهود و المبادرات المــرية

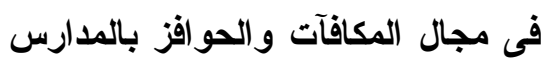
الثانوية العامة : من أهم هــــه الجهـــود و المبــادرات

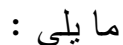

r-r - أوجه القصور والسلبيات فى محور

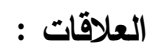

رغم الجهود و المبــادرات الرســمية

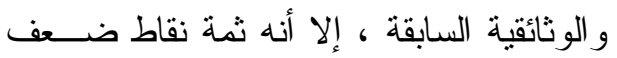
عديدة فى هذه المحور ، منها : -ضعف اهتمام إدارة المدرســـة الثانويـــة

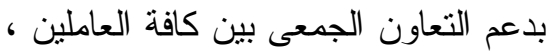

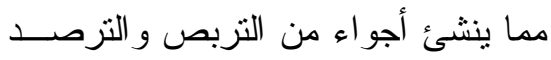

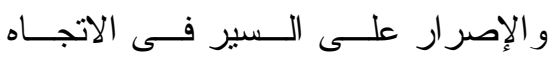
المعاكس حيال آراء ومقترحات العاملين بالمدرسة ، الأمر الذى يوفر مناخاً لفقدان آليات الثقة التنظيمية . - ضعف العلاقات الإنسانية السليمة التـى

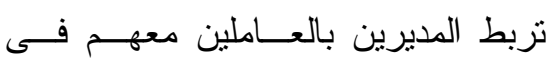

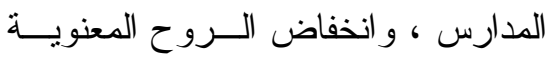

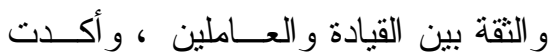

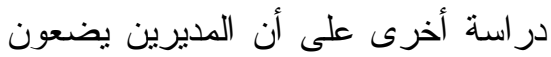

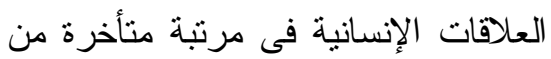

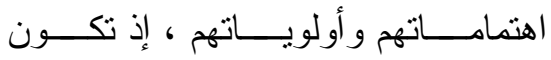

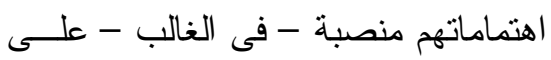

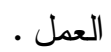
- ضعف التعاون بين الوحدات المتتوعـــة

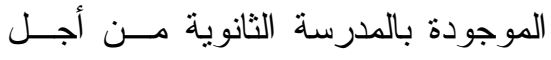

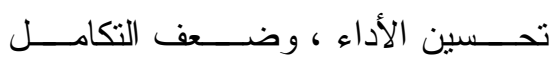

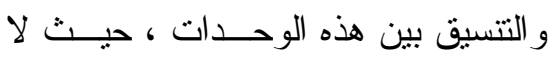
توجد آلية تسمح بمشاركة الوحدات فيما

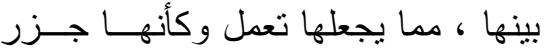
منعزلة داخل المدرسة . 
الأنــشطة التزبويـــة و الريــادة العلميـــة

$$
\text { و غير ها . الان. }
$$

- أكدت الخطة الاستر اتيجية للتعلــيم قبــلـ

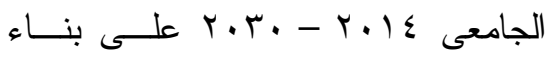

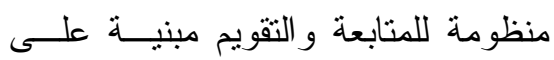

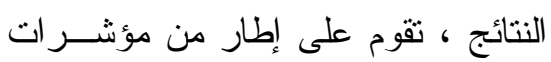

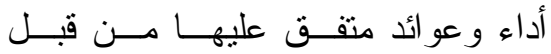

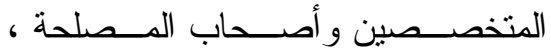
بحيث ترنبط الحو افز و غيرهــــا بالنتــائج على جميع المستويات الإدارية بــوزارة

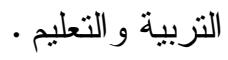

ـ - - - أوجه القصور و السلبيات فى محور المكافآت و الحو افز : المعن رغم بعـض الجهــود و المبــادرات

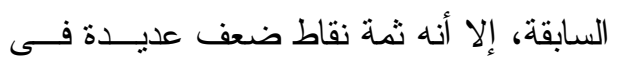
هذا المحور ، من أهمها :

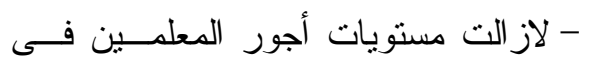
مصر منخفضة مقارنة بارتفاع معـدلات

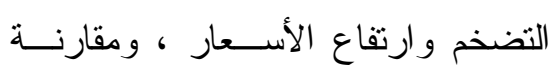

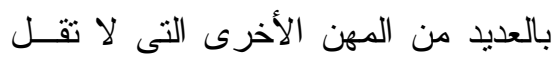

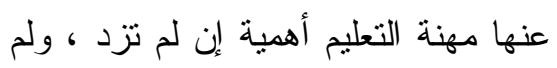

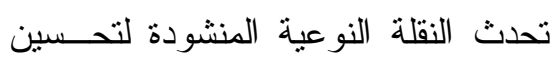

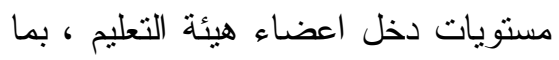

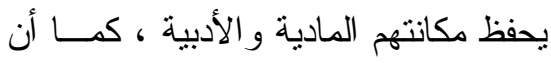

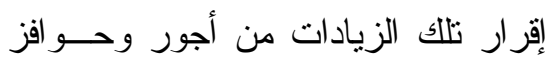
ومكافآت المعلمين ، لم يصاحبها تحسـسن من الجرد

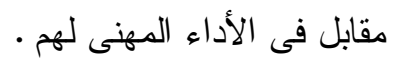

- إصدار القانون رقم 100 لــسنة V. V.

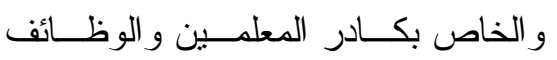

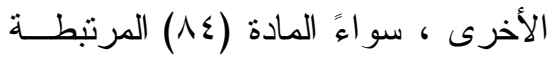

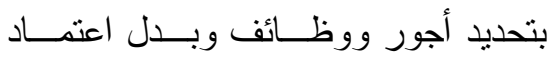
أعضاء هيئة التعلـيم ، أو المــادة (10)

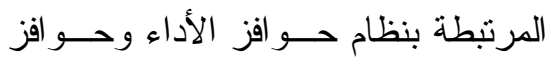
الإدارة وحو افز التميز العلمى للحاصلين

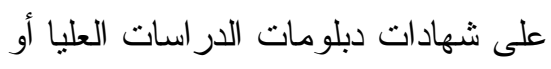

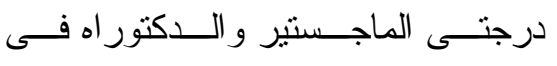

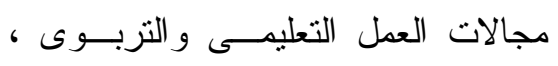

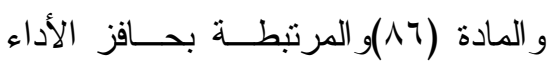

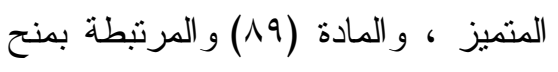

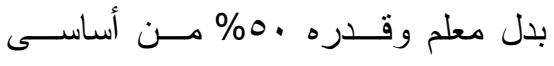

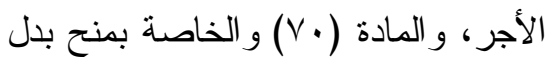

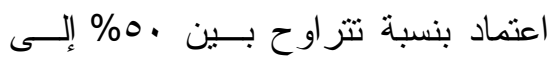

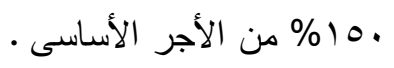

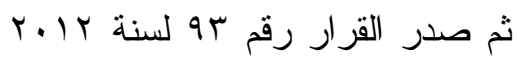

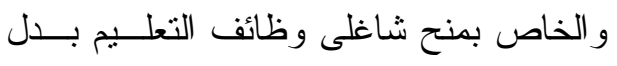

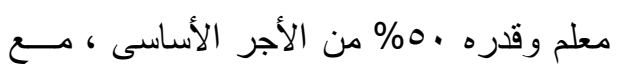

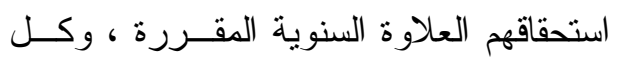
زيادة فى الأجور تمــنح اللعـاملين بالجهــاز

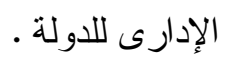

- تتوع المكافآت التى تقدم لأعضاء هيئــة

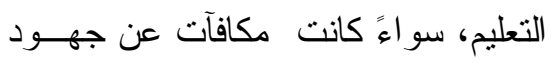

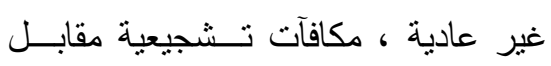

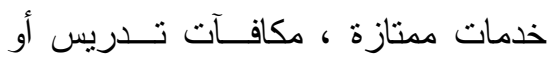

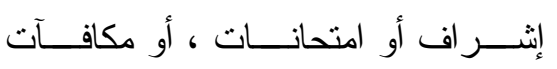




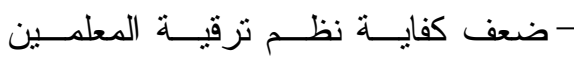
و العاملين ، لاعتماد الترقية على معيــار

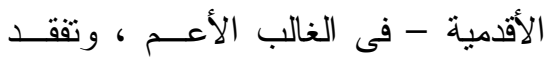

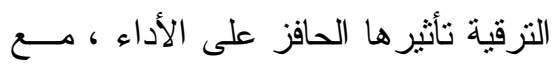
بقاء احتمالات الرسوب الوظيفى قائمة . - يتضح من القرارات الخاصـــة بمكافــأة

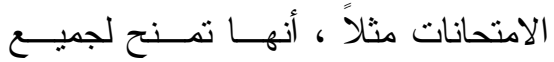
العاملين بالمــــارس الثانويــة ، ســـــاءً أصحاب الأداء المتميز أو أصحاب الأداء الضعيف ، أو العاملين فى ديـــوان عــام الوزارة أو المديريات و الإدار ات التعليمية ، فسياسة الحوافز فى مصر لا تمبز بين

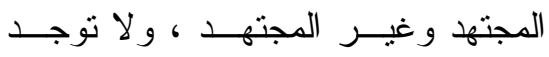

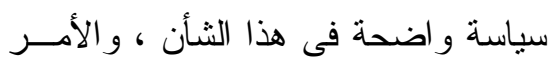

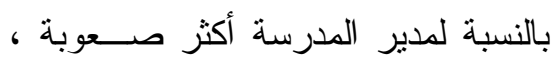
فهو ليس بمقدوره إثابة المعلم أو الموظف لمديف

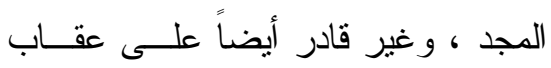

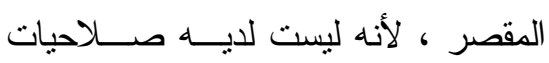

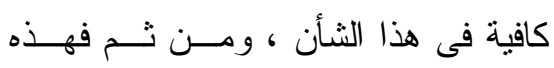

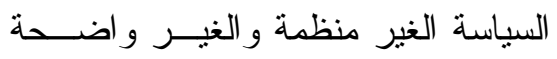

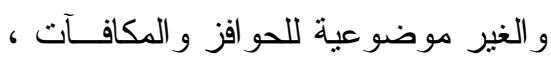
أساءت إلى جميع من بالعملية التعليمية ،

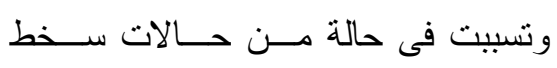
الجميع على حال التعليم فى مصر . 0-القيادة : ويتم تتاول هذا المحور علــى النحـــ
- ضعف الحو افز التى تجــذب المدرسـين ذوى الكفاءة و القدرة للعمــل كمــديرين

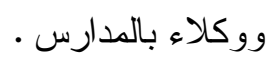
- أكدت إحدى الدراسات على وجود العديد

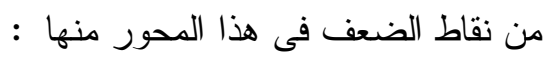
• قلة منح الحو افز المادية والأدبية.

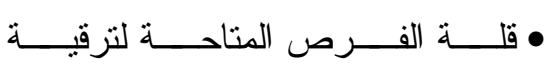
المعلمين. • لا يوجد ربط كافى بين مــا يحـصل

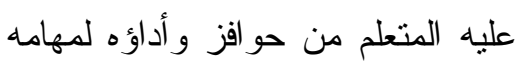
الوظيفية. • لا توجد عدالــة كافيــة فـى توزيــع الحو افز على المعلمين.

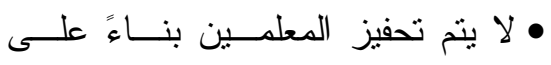
سياسات معلنة وو اضحة.

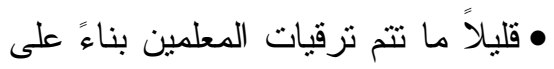
معايير موضو عية و عادلة.

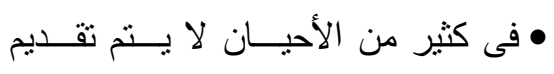
الحو افز بصورة دورية ومستمرة. - وجود معوقات إدارية ومالية وتتظيميــة تحد من سلطة مديرى المدارس فى تقديم

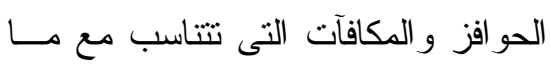

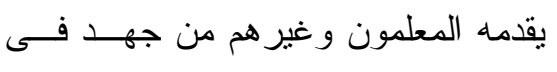

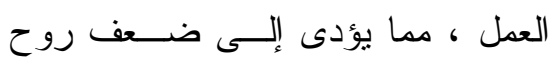

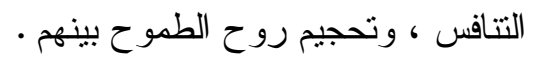

$$
\text { التالى : }
$$


- - فى عام V . . قدمت الأكاديمية المهنية

للمعلمين برنامج المجتمعــات المهنيــة للتعلم لتتمية القيادات المدرسية. - قامت إدارة التدريب بمر اكــز التطــــير

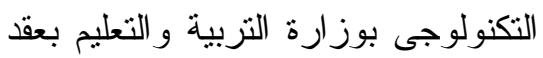
عدد من الدور ات التدريبية منـــ عــام

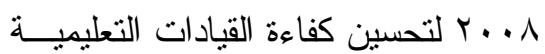
بالمرحلة الثانوية .

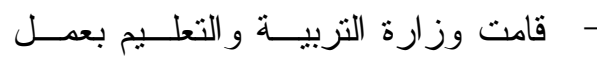

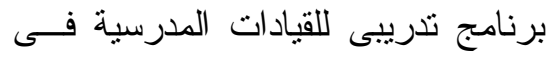
الاتجاهات المعاصرة فى إدارة الددرسة

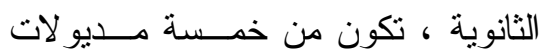
ترتبط بالاتجاهات المعاصرة ومهــار ات

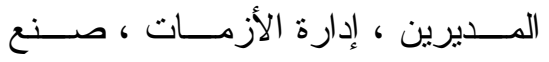

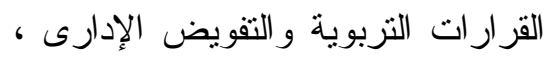
التقويم الذاتى • قدمت الأكاديمية المهنية للمعلمـين فـى

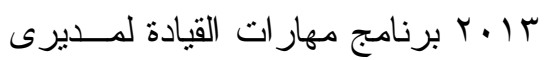

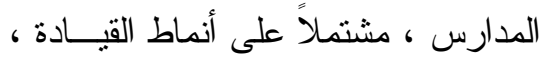

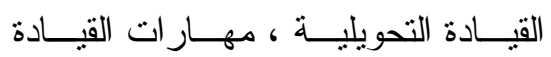
التعليمية فى إدارة التغيير ، نواتج التعلم

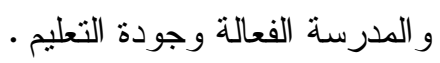

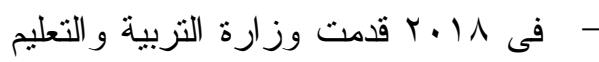
برنامجاً تدرييياً لتدريب القيادات العليــا

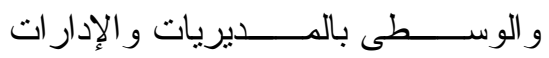
التعليمية على إعداد الصف الثانى لتولى بلى ولى المهام القيادية العليا.
ه - 1 - بعض الجهود والمبادرات المــصرية فى مجال القيادة بالمدرسة الثانوية العامة : من أهم هـــذه الجهـــود و المبــادرات ما يلى :

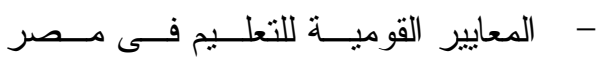

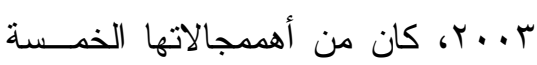

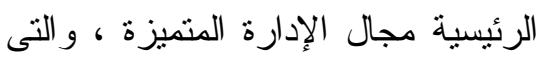

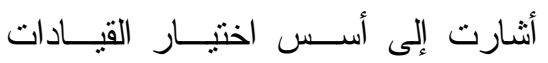

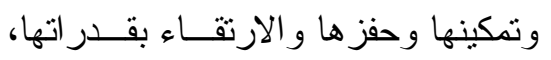
كما تضمن المجال الثانى وهو المنـــاخ الاجتماعى المدرسى فى وثثقة معسايير المدرسة الفعالة عدة معايير ، كان منها: قيادة مدرسية فعالة ، وحدد هذا المجال

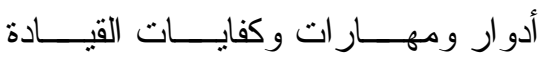
المدرسية الفعالة . - قدمت وزارة التزبية و التعليم بالتعـاون

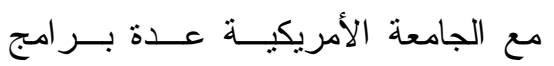

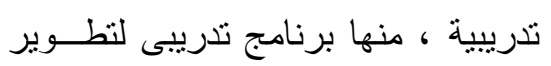

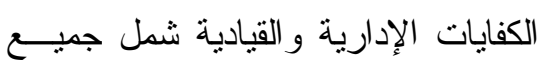

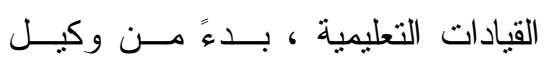
مدرسة إلى وكيل أول وزارة . - - تضدنت وثيقة معايير الجودة و الاعتماد

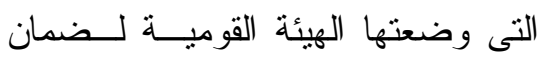
جودة التعليم و الاعتماد وعدة مجــالات

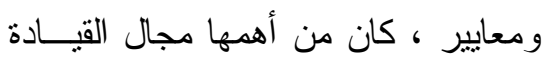
و الحوكمة. 
المقدمة لهم ، مما يحــول دون قبــامهم

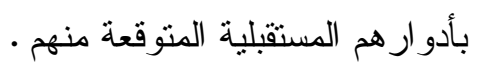
وجود عجز شديد فى القيادات المؤهلـــة و المدربة ، و القادرة على إدارة العمليـــة

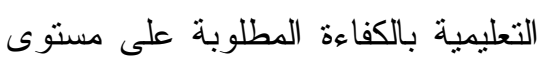
المدرسة . ضعف قدرة عدد كبير من قيادات التعليم

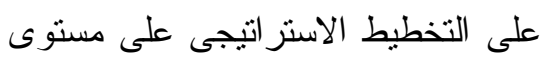

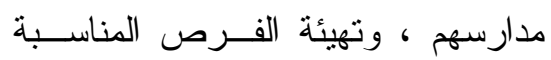

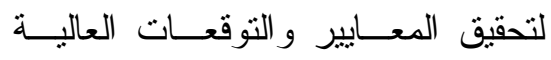

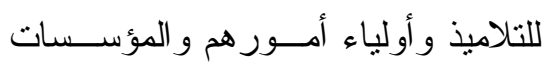
المجتمعية الأخرى المعنية بالتعليم ـ

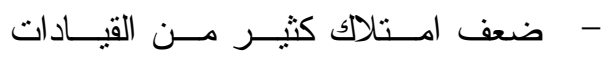

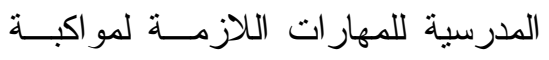
التغير المعرفى و التكنولوجى ، و القــدرة على ترسيخ قيم التميز • لعيز لاز ال أسلوب اختيار القيادات التعليميـــة

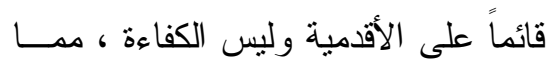

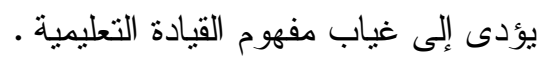
لاز الت الأنماط القيادية التقليدية سـائدة

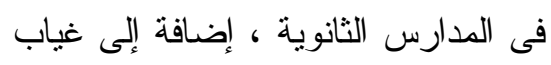

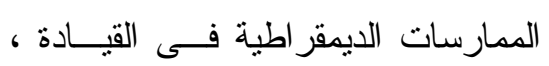
وشيوع نمط القيادة الأوتوقر اطية .

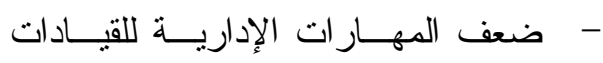

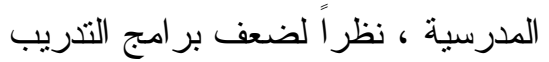
المرتبطة بها ، وتقليدية مادتها العلميــة وورش العمل بها ، اضافة إلــى قلـــة

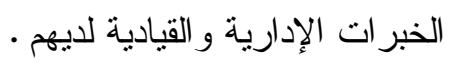

ه-r - أوجه القصور والسلبيات فى محور

$$
\text { القيادة : }
$$

على الرغم من الجهود و المبــادرات الرسمية و الوثائقية السابقة ، إلا أنه ثثة أوجه وله قصور ونقاط ضعف عديدة فى هذا المحــور منها : - فقدان الممارسات القياديــة لاحتر افيـــة

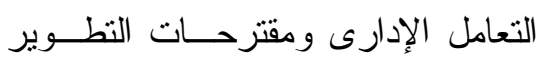
الواردة من العاملين و المعلمين ، وندرة

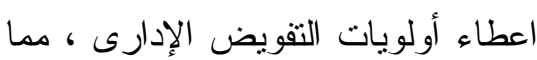

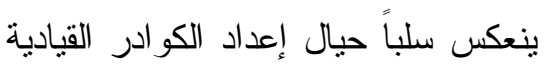

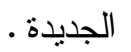
وجود مديرين غير مؤهلين وغير معدين

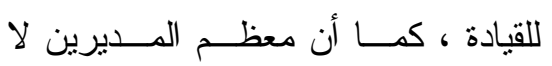
يرحبون بالتغيرات الجذرية ذات الفوائد الكبيرة المستقبلية . - صعوبة تحديد وقيــاس فجـــوات الأداء

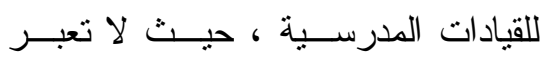

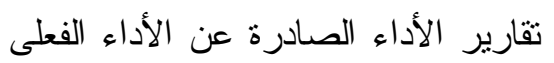
للقيادات . تلقرد - - عزوف العديد من مــديرى المــدارس

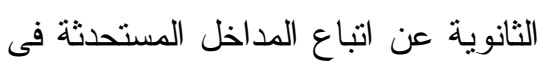

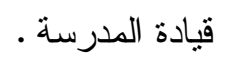

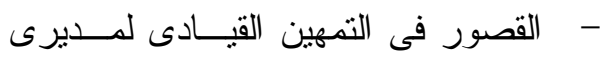

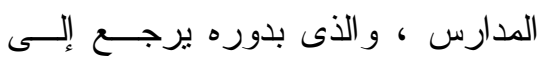

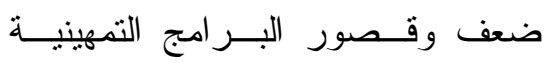


- - الاهنمام بالتتمية المهنية المستذامة لكافة المنتسبين للمدرسة الثانوية ، من خــلال

برنامج التتمية المهنية و إدارة المــوارد

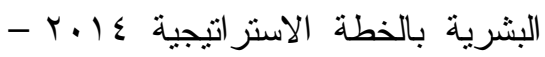

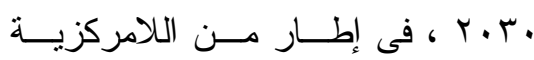
و الحوكمة الرشيدة ، وفى إطار دولـى كلى • متميز - كما ظهر الاهتمــام الرســـى بالتتميــة

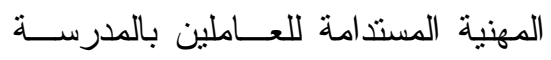
الثانوية من خلال مؤشــرات المعــايير القومية للتعليم فى مصر ، وما حددتــــ ماله

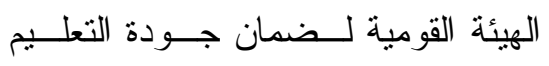
و الاعتماد من معايير ومؤشرات مرتبطة بتلك الجزئية ، بل و إنــشاء الأكاديميــة المهنية للمعلمين كهيئة مهنيـة رســـية تضطلع بتلك الأمور -

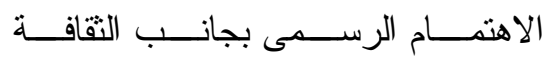

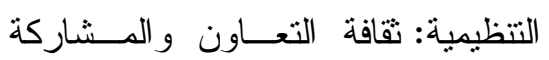
و التميز و الثفافية و العدالة وروح الفريق و التجديـــــ و التغييـــر و الإبـــداع و الثقـــة المتبادلة.

وجود معيار مخصص للموارد الماليــة و المادية بوثيقة الاعتماد للهيئة القوديـة ميـة لضمان جودة التعليم و الاعتماد ، ومدى كفاية هـــهـ المـــوارد لتحقيــق رســـالة المدرسة و أهدافها ، وكيفيــة اســتخدام

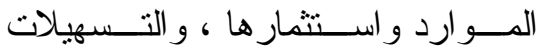
المادية سواءً لممارسة الأنشطة الطلابية
צ-الآليات المساعدة :

ويتم تناول هذا المحور علــى النحـــو التالى

צ-1 - بعض الجهود والمبادرات فى مجال

الآليات المـسـاعدة بــإدارة المدرســة الثانوية العامة : العاتة من أهم هــذه الجهــود و المبــادر ات ما يلى :

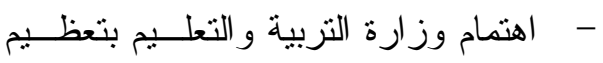
دور تكنولوجيا الاتصـالات و المعلومـــات

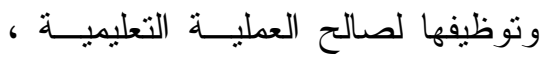
وظهر ذللك من خلال اثــتمال الخطــة

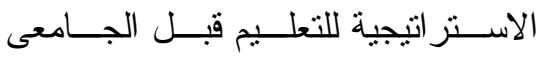
ع 1 . مخصص لتتمية نظم المعلومات التربوية و المالية ، هدفه العام توفير نظام متكامل راقى الجودة للمعلومات التربوية و المالية متاحة للاستجابة الفورية لصناع القــرار و أصحاب المصلحة ، تشتتد على بنيــة

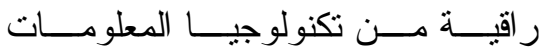

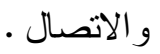

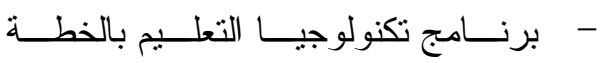

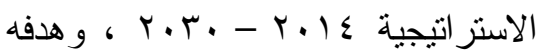

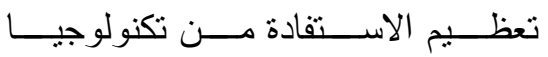
المعلومات و الاتصالات فى الممارسات التربوية و الإدارية . 


$$
\text { • تفشى ظاهرة الانسحاب و التهرب من }
$$

• ضعف قيم المبادأة و المبادرة و الإقبال

$$
\text { على التغيير - منع }
$$

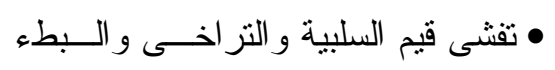$$
\text { الثديد و التسلط وضعف المسئولية. }
$$$$
\text { • زيادة المقاومة للتغيير • }
$$

• ضعف نشر وتـــــيم ثقافـــة تمكـين

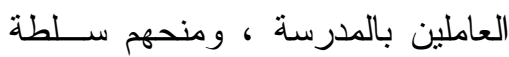

$$
\text { التصرف فى مو اقف العمل. }
$$

• التركيز على العوامل الثخصية أكثز

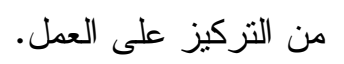

- - عدم اعطاء اهنمام للقاءات الحواريـــة -

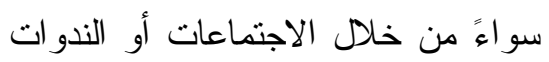

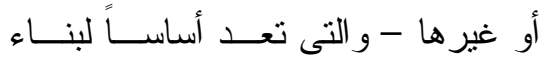

جدران الثقة التتظيمية ، هذا بالإضـافة

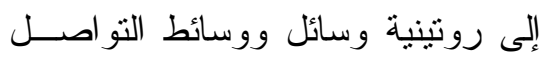
الإدارى ، مما يعرقل حصول العـاملين

على المعلومات و المعارف التتظيمية .

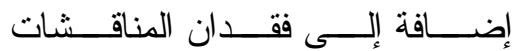

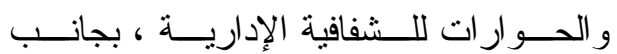
العر اققيل الإدارية التـى لا نتــسر اســتخدام المعارف التنظيمية.

- - قلة استخدام أساليب الاتصالات المنبادلة

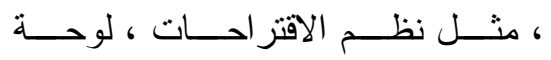

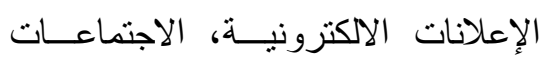

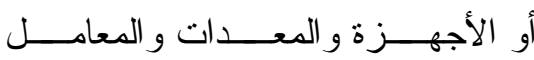

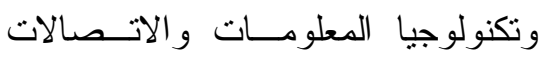

باعتبار ها آليات و أدوات مفيدة ومساعدة

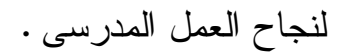

צ-r - أوجه القصور والسلبيات فى محور الآليات المساعدة :

رغم بعـض الجهــود و المبــادرات

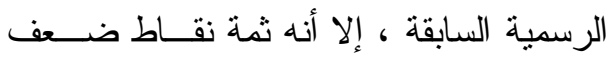

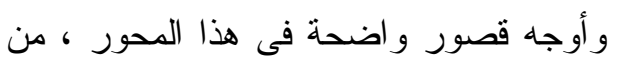
أهمها : واوجه

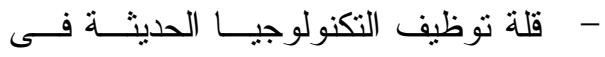
المدرسة الثانوية العامة ، مما يعنى ندرة

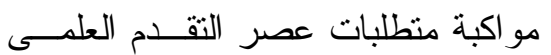

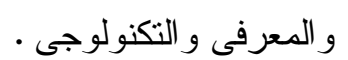

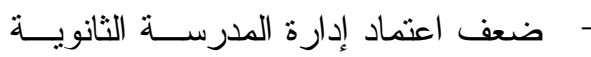
على تكنولوجيا المعلومات و الاتصالات وتوظيفها ، و واستخدام الأساليب التقليدية

$$
\text { فى إدارة المدرسة . }
$$

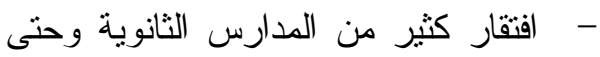
المعتمدة منها إلى قو اعد بيانات تكــون

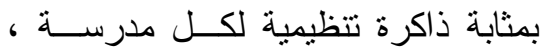

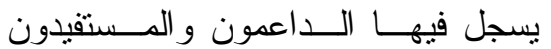
و الأطر اف ذات العلاقة . - - ضــــف التقافـــة التتظيميـــة الـــــائدة بالمدارس الثانوية العامة ، ومــن أهــ مظاهر هذا الضعف :

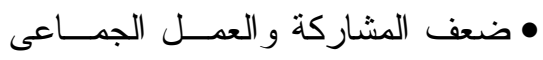
وروح الفريق. 
يجرى البحث الحالى در اسة ميدانيــة لو اقــع

التتخيص التتظيمى بالمدارس الثانوية العامة

بمحافظة الثرقية.

الخطــــوة الرابعـــة : الدراســـة الميدانيـــة

\section{و إجر اع|تها :}

أ-إجراعات الار اسـة الميداتية :

تتمنتل إجــر اءات الدر اســـة الميدانيـــة

فيما يلى :

1-هدف الدراسة الميدانية :

استهدفت الدراسة الميدانية الوقــوف

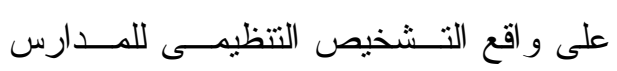
الثانوية العامة بمحافظة الثرقية مــن خــلاد

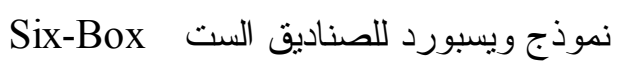

.Model

r-أداة الدراسة الميدانية :

قامت الدراسة بإعداد استبيان تكـــن

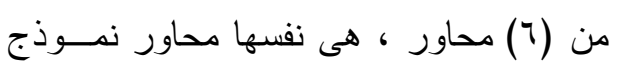

ويسبورد ، وقد استعان الباحث فــي اعـداد

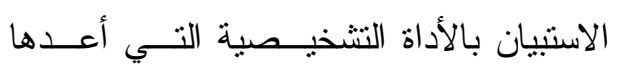

ويسبورد و المكونة من ( • ) فقرة، وتكون

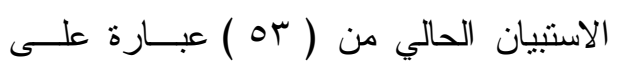

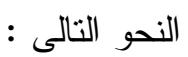

المفتوحة ، و الحوارات الفعالة ، إضافة إلى أن إدارة المدرسة الثانوية لا تشجع الأفر اد علــى الــسؤال عــن المــــاخل

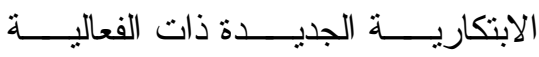

النتظيمية، وندرة الدعم الإدارى ماديــاً ومالياً للأفكار الإبداعية ، وندانب خوف لإن الادرى وتردد المدر اء من التغيير و التجريب. - - متعف اهتمام المديرين بتشجيع العاملين و المعلمـين علــى حــضور النــدوات و المؤتمر ات التزبوية.

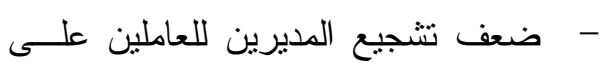
البحث عن فرص جديدة للنمو أو التتمية

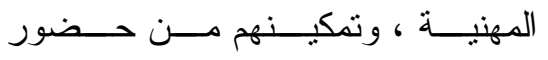
المـــؤتمر ات و اللقــــاءات و الاجتماعــــات التربوية و المشاركة فى الزيــار ات ذات

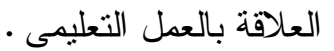
يتضح مما سبق أنه على الرغم مــن بعض الجهود و المبادرات المصرية فى مجال

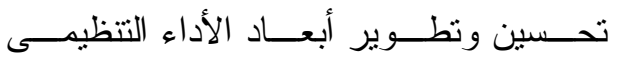
بالمدارس الثانوية العامة ، إلا أن ثمة أوجـهـ قصور عديدة ونقاط ضعف منتوعة فى كـلـ لـ إلـ

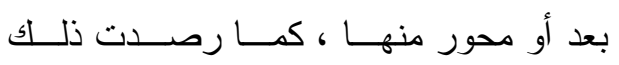

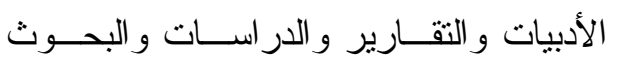

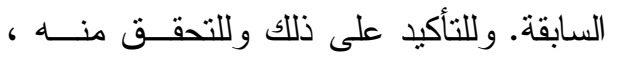




\begin{tabular}{|c|c|c|}
\hline \multicolumn{3}{|c|}{ جدول (1) محاور الاستبيان وعبار اته } \\
\hline عدد العبارات & عنوان المحور & رقم المحور \\
\hline$\wedge$ & الأهداف & 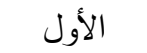 \\
\hline 9 & الهيكل التنظيمى - الت & الثانى \\
\hline v & العلاقات & الثالث \\
\hline 9 & المكافآت و الحو افز & الر ابع \\
\hline 1 . & 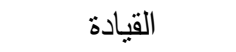 & 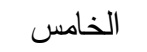 \\
\hline 1. & الآليات المساعدة & السادس \\
\hline or & \multicolumn{2}{|c|}{ اجمالى فقرات الاستبيان } \\
\hline
\end{tabular}

-بلــنغ إجمــالى عـدـد المعلمــين بكافــة مستوياتهم الوظيفية بالمــــارس الثانويـــة

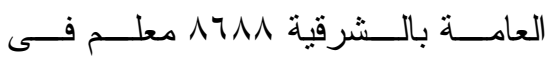

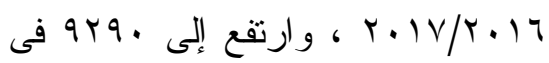

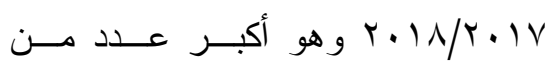

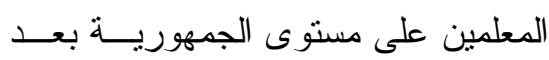
القاهرة مباثرة.

- بلغ عـدد الهيائــة الإداريــة (المــديرين

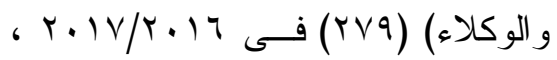

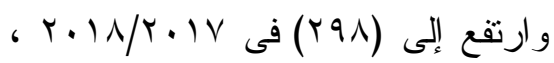
وهى فى التزتيب الثالث بعــــ القـاهرة و القليوبية.

- بلغ جملة العاملين بالمــدر اس الثانويـــة العامة بالــشرقية مــن معلمـين و إدارة مدرسية و أخصائيين و إداريـين و وعـــال

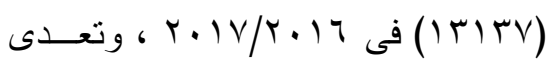

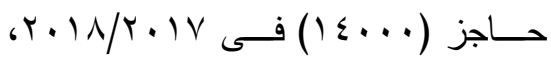

يشمل مجتمع البحث الهيئة الإداريــة

(المدير و الوكلاء) و الهيئة التدريسـيـة (كافــــة

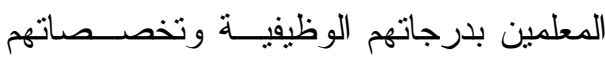

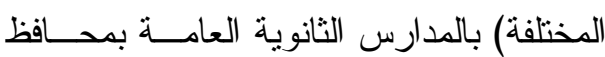

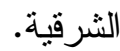

ـ -مبررات تطبيق الاستبيان على محافظــة

$$
\text { الشرقية : }
$$

من بين هذه المبررات ما يلى : - تـــضم محافظـــة الــشرقية (•r) إدارة تعليمية منتوعة المستويات ، وهى مسن

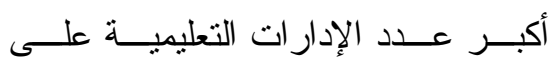
مسنوى الجمهورية. - عدد المدارس الثانوية العامة فى الثرقية

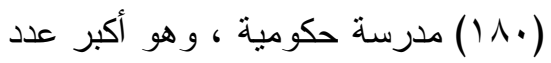

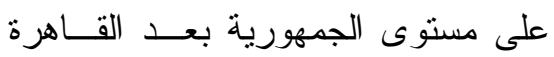
فقط. 
- تم التضبيق على عدد (r/) مدرســة

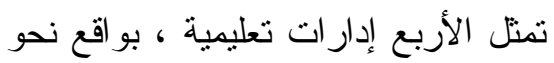

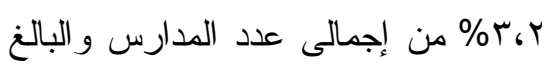

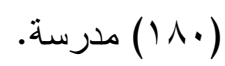

- تم التطبيق على عدد (·r) مــن الهيئــة الإدارية (المدير و الوكلاء) وهـــو عـدند

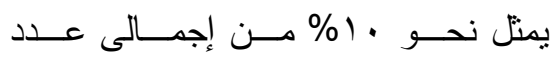
المديرين و الوكلاء بالثرقية.

- تم التطبيق على (• (Y) معلم بالإدارات

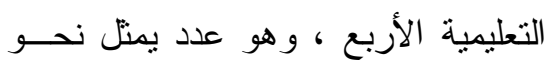

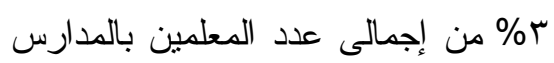
الثانوية العامة بالشرقية.

- بلغ إجمالى العينة من الهيئـــة الإداريـــة و العيئة التدريسية (.9. (Y) فرد. و الجدول التالى يبين توزيع عينة الدراسة

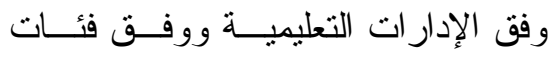

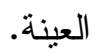

و هو أكبر عدد على مستوى الجمهوريـــة بعد القاهرة مبانشرة. كما تمثل محافظـــة الــشرقية تتوعـاً و اضحاً لكافة البيئات ، الزر اعية و الــصناعية و الصحر اوية ، إضـافة إلى الحضر و الريــف و البدو ، و هذا راجع إلـى اتسـساع مسـساحتها

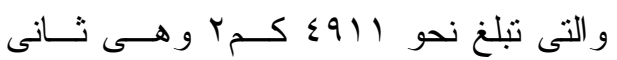
محافظة على مسنوى الجمهورية فى المساحة

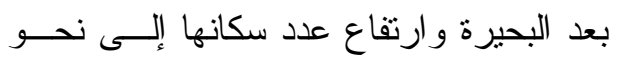

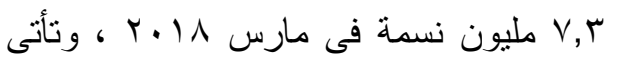

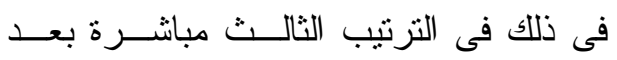

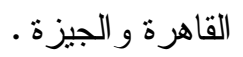

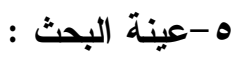
تمنتلت عينة البحث فيما يلى :

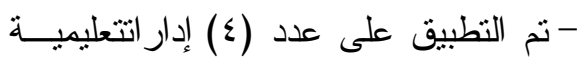
بالثرقية وهى : شرق الزقازيق ، بلبيس

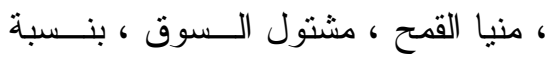
. و البالغ عددها (·. إد) إدارة.

\section{جدول (r) يبين توزيع عينة الدراسة}

\begin{tabular}{|c|c|c|c|c|}
\hline المجموع & الهيئة التدريسية & الهيئة الإدارية & عدد المدارس & الإدارة التعليمية \\
\hline ov & or & 0 & $r$ & شرق الزقازيق \\
\hline $9 \wedge$ & AV & 11 & $\varepsilon$ & بلبيس \\
\hline ᄉ) & VT & 9 & $\varepsilon$ & منيا القمح \\
\hline $0 \leqslant$ & $\leq 9$ & 0 & r & مشتول السوق \\
\hline rq. & YY. & $r$. & $\pi$ & الإجمالى \\
\hline
\end{tabular}




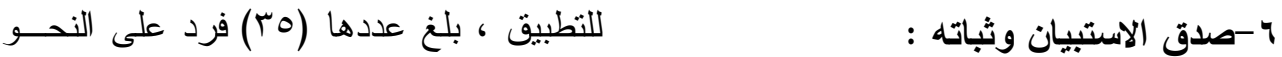

$$
\begin{aligned}
& \text { قامت الدراســـة بتطبيــق الاســنيان }
\end{aligned}
$$

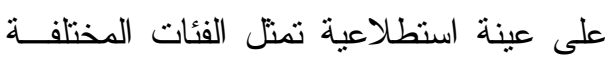

$$
\begin{aligned}
& \text { جدول (r) }
\end{aligned}
$$

توزيع العينة الاستطلاعية للاراسة الميدانية

\begin{tabular}{|c|c|c|}
\hline النسبة المئوية & العدد & الفئة \\
\hline ro,V & 9 & الهيئة الإدارية \\
\hline$V \varepsilon_{6} r$ & rT & الهيئة التدريسية \\
\hline$\% 1 \ldots$ & ro & المجموع \\
\hline
\end{tabular}

ع צr، . من "يسود الــمط المركـزى إدارة 1 - 1 - 1 - صدق الاستبيان :

المدرسة الثانوية" إلى "تدار المدرسة الثانويــة

تم حساب معــاملات الارتبــاط بـين درجة كل مفردة بين المفردات والدرجة الكلية العامة بالأسلوب المركزى". المحور الثالث : العلاقات

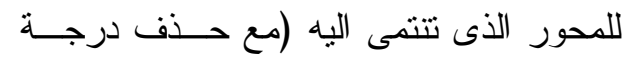
تزراوحت قيم معامل الارتبــاط بـين

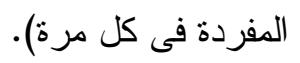

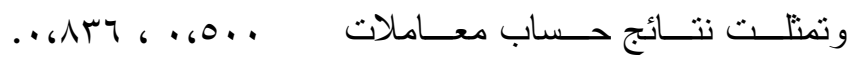

المحور الرابع : المكافآت والحوافز الارنباط للمحاور الستة كما يلى : تراوحت قيم معامل الارتبــاط بـين

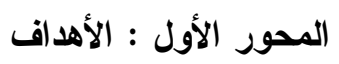

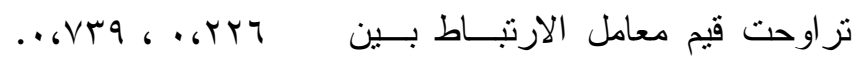

وبناءً عليه نم حذف العبارة رقـم (^)

ومفادها " تقدم الحوافز و المكافــآت للجميـع المحور الثانى : الهيكل التنظيسى

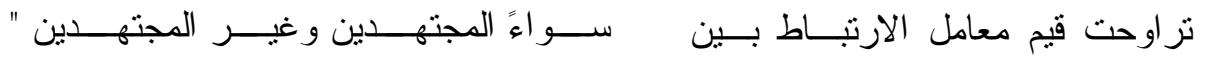

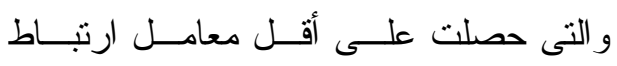

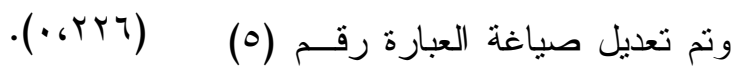

$$
\begin{aligned}
& \text { و التى حصلت علــى أقــلـل معامــل ارتبــــاط }
\end{aligned}
$$


0.، ؛ ، مما يدل على الاستنيان بشكل عــام على درجة عالية من الاتساق الداخلى.

צ- - ثبات الاستبيان : تم حسساب ثبــات

$$
\text { الاستبيان على النحو التالى : }
$$

أ-ثبات المفردات : تــــ فيهـا حسـاب

معامل "ألفا كرونباخ" (فى حالة حذف

درجة المفردة) ، وكانت قيم معاملات

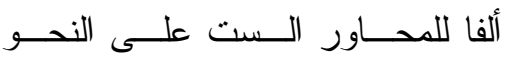

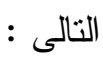

المحور الخامس : القيادة

وتز اوحت قيم معامل الارتبــاط بــين

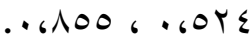

المحور السادس : الآليات المساعدة

تزاوحت قيم معامل الارتبــاط بـين

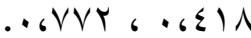

وباسنتثاء العبارة التى تم تعديلها فـى لـ

المحور الثانى ، و العبارة التى تم حذفها مـن

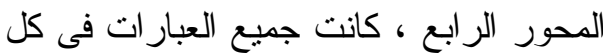

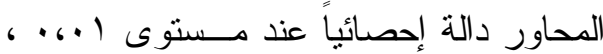

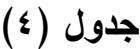

قيم ثبات محاور الاستبيان وفق معامل ألفا كرونباخ

\begin{tabular}{|c|c|c|}
\hline قيمة معامل الثبات & المحور & 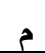 \\
\hline . & الأهداف & 1 \\
\hline . 670. & الهيكل التتظيمى & r \\
\hline $.610 \mathrm{~V}$ & العلاقات & r \\
\hline $.6 V \circ V$ & المكافآت و الحو افز & $\varepsilon$ \\
\hline .69 & القيادة & 0 \\
\hline . ، & الآليات المساعدة & 7 \\
\hline .6949 & الاستب & \\
\hline
\end{tabular}

وكانت قيمة معامل ثبــات الاســنيان ب-حساب ثبات الاستبيان ككل ومحاوره :

حسب ثبات كل محور مسـن محساور

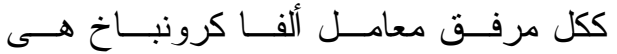

الاستبيان - بعد حذف المفردات غير الصادقة

(9 9 ، • ) ) وهى قيمة مرتفعة.

و غير الثابتة - بطريقتين : طريقة "جتمــان"

للتجزئة النصفية ، وكانت قيم معامل الثبــات

للمحاور الست على النحو التالى : 
جدول (0)

قيم ثبات محاور الاستبيان وفق طريقة التجزئة النصفية "جتمان"

\begin{tabular}{|c|c|c|}
\hline قيمة معامل الثبات & المحور & م \\
\hline . & الأهداف & 1 \\
\hline . & الهيكل التنظيمى & r \\
\hline . ‘. & العلاقات & r \\
\hline . 6147 & المكافآت و الحو افز & $\varepsilon$ \\
\hline $.9 . \varepsilon$ & القيادة & 。 \\
\hline . 2007 & الآليات المساعدة & 7 \\
\hline$. .9 . v$ & الاستييان ككل & \\
\hline
\end{tabular}

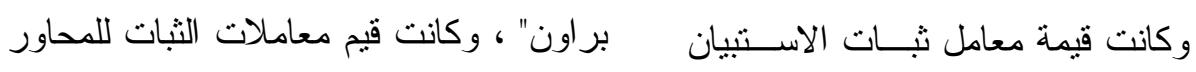

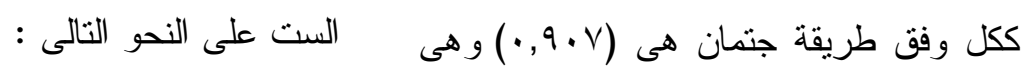

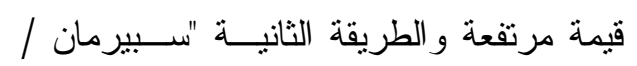

جدول (7)

قيم ثبات محاور الاستبيان وفق طريقة سبيرمان/براون

\begin{tabular}{|c|c|c|}
\hline قيمة معامل الثبات & المحور & 5 \\
\hline - & الأهداف & 1 \\
\hline . & الهيكل التنظيمى & r \\
\hline 次A & العلاقات & $r$ \\
\hline .6997 & الدكافآت و الحو افز & $\varepsilon$ \\
\hline .69 .7 & القيادة & 。 \\
\hline .6V74 & الآليات المساعدة & 1 \\
\hline .6914 & \multicolumn{2}{|c|}{ الاستبيان ككل } \\
\hline
\end{tabular}




\section{وبلغت قيمة معامل ثبــات الاسـتبيان V-المعالجة الإحصائية :}

- تم تفريغ بيانات الاســنيان واســتخدام ككل وفق طريقة سبيرمان/بـــر اون (r (9)، •) الجداول التكرارية لحساب التكـــرارات

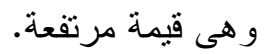
لكل عبارة من العبار ات أمام الاستجابات

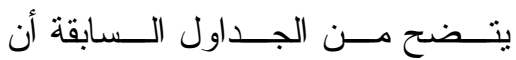

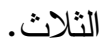

قيم معامل ثبات الاستبيان بالطرق الــثلاث ،

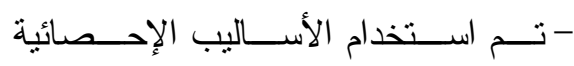
سو اءً لكل محور علــى حــدة أو للاسـتنبيان التالية :

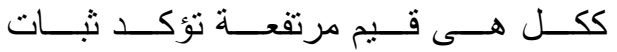
• حساب النسب المئوية للتكر ار ات.

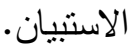
استخدمت الدراسة مربع (كاب) للتأكـــ من درجة الثقة فى الاستجابات ومــدى من الإجراءات السابقة تأكد للباحــث

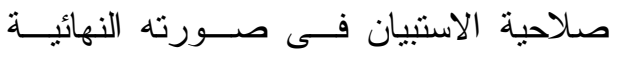
صدقها ونوزيعها من تكر ارات ونسـسب و المكون من (Or) مفردة للنطبيق فى البحث توزيعاً حقيقياً باستخدام برنامج Spss)

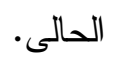
وتكون الاستبيان فى صورته النهائية

ب-نتائج الدراسة الميدانية وتفسيرها : من (Yr) مفردة ، يجاب عنها عـن طريسـق بعــــــــــاء إلمعالجــة الإحــصائية ثلاثة بدائل للاختيار وهى (متوفرة - منوفرة للبيانات ، تم رصد النتائج فى صورة جداول

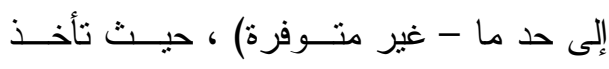
إحصائية وتقسير ها كما يلى :

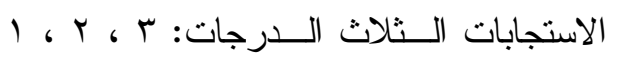
ا-النتائج المتعلقة بالمحور الأول "الأهداف":

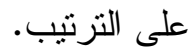
يوضـح الجدول التــالى هــــه النتــائج كما يلى : 
جدول (V) استجابات أفراد العينة على العبارات الخاصة بمحور الأهداف

\begin{tabular}{|c|c|c|c|c|c|c|c|c|c|c|}
\hline الدلالة & مستوى الدلاكة & قريمة & الحستبى المتط & متوفرة & متوفرة إلى ما & متوفيرة & العينة & والنسبة & العبارات & م \\
\hline دال & 0.000 & 41.407 & 2.28 & 148 & 76 & 66 & 290 & التكر ار & \multirow{2}{*}{ 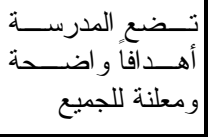 } & \multirow[t]{2}{*}{1} \\
\hline & & & & 51.0 & 26.2 & 22.8 & 100 & المئوبة & & \\
\hline \multirow[t]{2}{*}{ دال } & 0.000 & 51.503 & 2.26 & 116 & 134 & 40 & 290 & التكر ار & \multirow{2}{*}{ 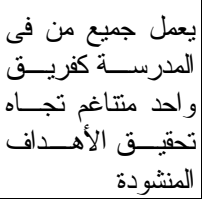 } & \multirow[t]{2}{*}{2} \\
\hline & & & & 40.0 & 46.2 & 13.8 & 100 & المئوية & & \\
\hline \multirow[t]{2}{*}{ دال } & 0.000 & 76.807 & 2.25 & 105 & 153 & 32 & 290 & التكر ار & \multirow{2}{*}{ 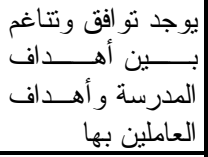 } & \multirow[t]{2}{*}{3} \\
\hline & & & & 36.2 & 52.8 & 11.0 & 100 & المئوية & & \\
\hline \multirow[t]{2}{*}{ دال } & 0.013 & 8.697 & 2.07 & 97 & 117 & 76 & 290 & التكر ار & \multirow{2}{*}{ 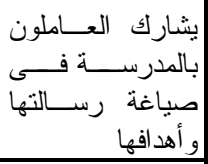 } & \multirow[t]{2}{*}{4} \\
\hline & & & & 33.4 & 40.3 & 26.2 & 100 & المئوية & & \\
\hline \multirow[t]{2}{*}{ دال } & 0.000 & 204.11 & 2.68 & 204 & 78 & 8 & 290 & التكر ار & \multirow{2}{*}{ 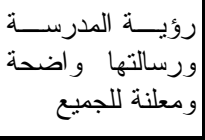 } & \multirow[t]{2}{*}{5} \\
\hline & & & & 70.3 & 26.9 & 2.8 & 100 & النئبة & & \\
\hline \multirow[t]{2}{*}{ دال } & 0.001 & 13.766 & 1.83 & 68 & 104 & 118 & 290 & التكر ار & \multirow{2}{*}{ 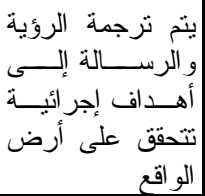 } & \multirow[t]{2}{*}{6} \\
\hline & & & & 23.4 & 35.9 & 40.7 & 100 & المئوية & & \\
\hline \multirow[t]{2}{*}{ دال } & 0.000 & 50.014 & 2.25 & 152 & 58 & 80 & 290 & التكر ار & \multirow{2}{*}{ 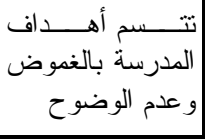 } & \multirow[t]{2}{*}{7} \\
\hline & & & & 52.4 & 20.0 & 27.6 & 100 & النسية & & \\
\hline \multirow[t]{2}{*}{ دال } & 0.028 & 7.145 & 2.12 & 112 & 102 & 76 & 290 & التكر ار & \multirow{2}{*}{ 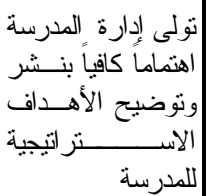 } & \multirow[t]{2}{*}{8} \\
\hline & & & & 38.6 & 35.2 & 26.2 & 100 & المئوية & & \\
\hline
\end{tabular}

\section{يتضح من الجدول السابق أن :}

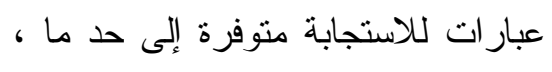
(Y) عبارة للاستجابة غير متوفرة.

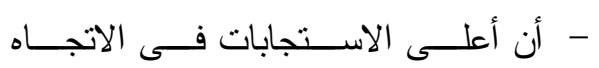

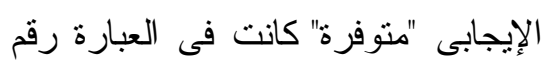

- استجابات أفراد العينة على هذا المحور

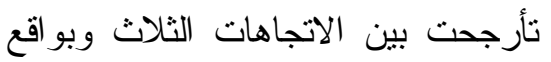

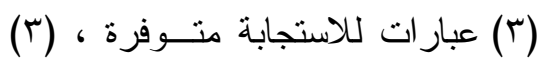


وتتقق هذه النتيجة مع دراسة "صلاح

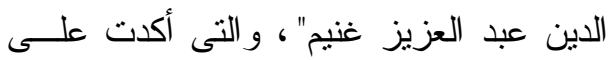

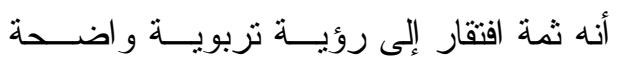

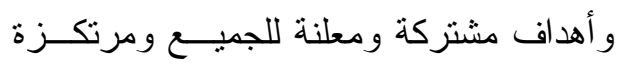

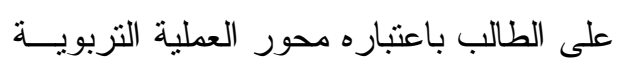

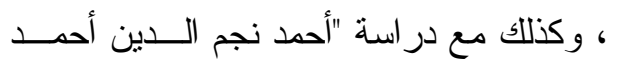

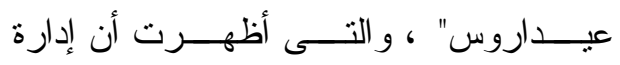
المدرسة الثانوية العامة لا نولى اهتماماً كافياً بتوضيح الأهداف الاستر اتيجية للمدرسة. - وفى تقدير البحث الحالى أن هذه النتائج

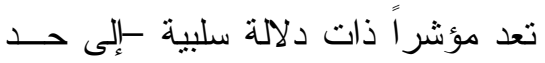

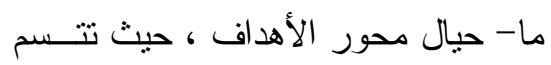

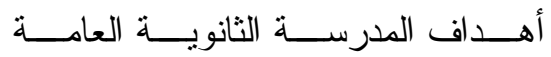

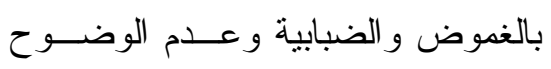

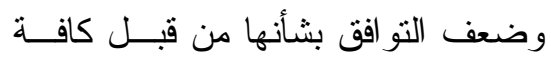

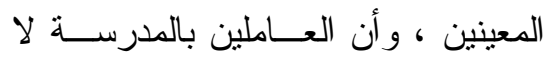
يشاركون - إلى حد ما- فى صـــياغتها

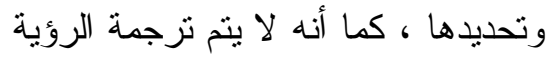
و الرسالة إلى أهداف حقيقيـــة إجر ائيـــة

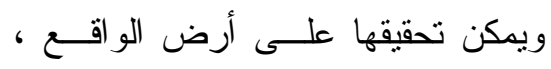

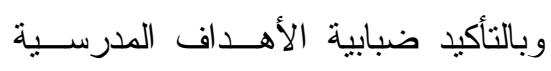

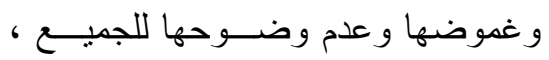

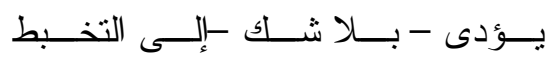

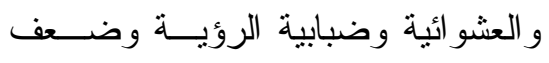
الإنجاز -

r-النتائج الخاصة بالمحور الثانى "الـهيكـل التنظيمى" : يوضح الجدول التالى هذه النتائج كما
(0) ومفادها "رؤية المدرسة ورســالتها

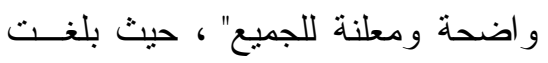

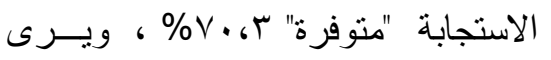

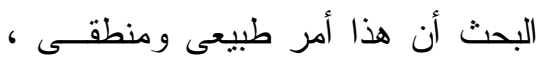

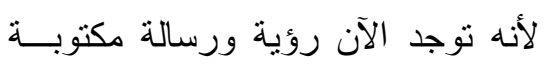
وو اضحة ومعلنة فى مدخل كل مدرسة.

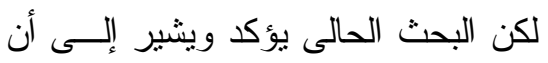
العبرة ليست بوجود رؤية ورسالة معلنة

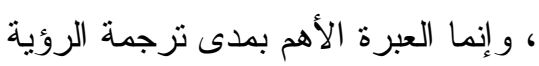
و الرسالة إلى أهداف استر اتيجية حقيقيـــة

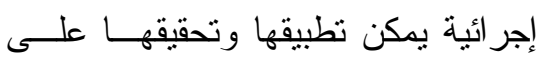

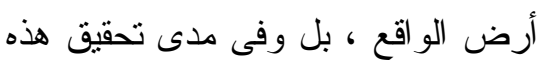
الأهداف. أرض الف.

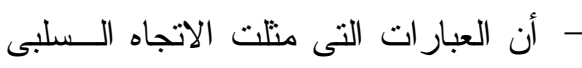

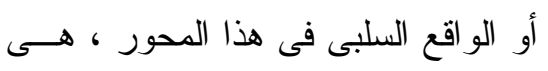

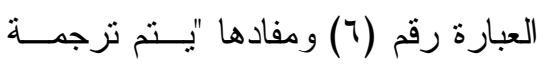
الرؤية و الرسالة إلى أهـــاف إجر ائيـــة

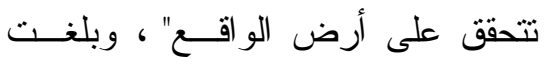

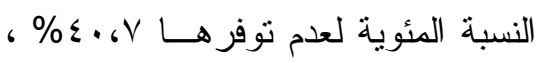

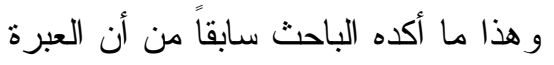

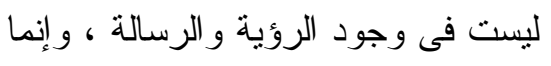

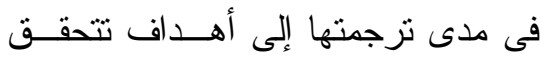

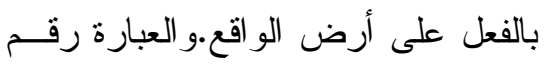

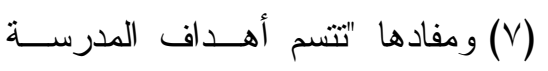
بالغموض و عدم الوضـــــ" ، وكانـــت

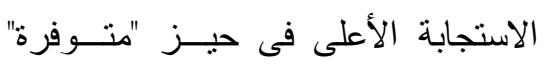

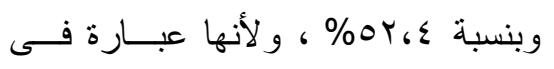

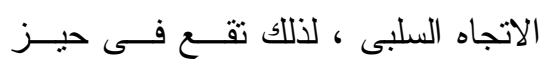

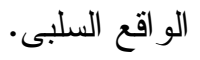




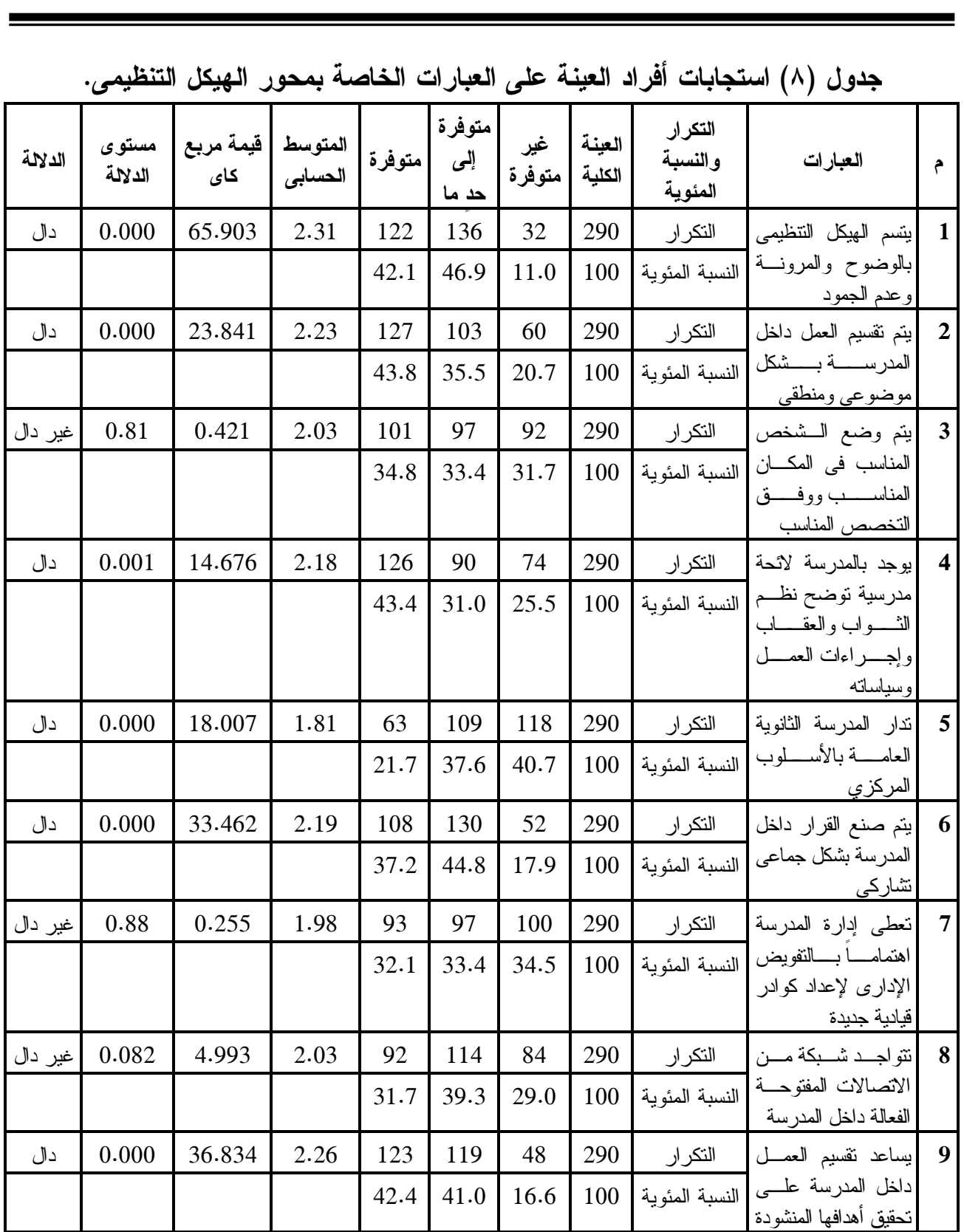

\section{يتضح من الجدول السابق ما يلى :}

ومنلتها (r) عبار ات ، و والاستجابة غيــر

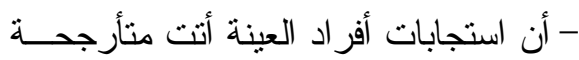

منوفرة ومنتلتها (Y) عبارة.

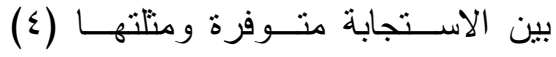

عبار ات ، و الاستجابة متوفرة إلى حد ما لاسل 
وتتفق هذه النتيجة مع دراسة كل من

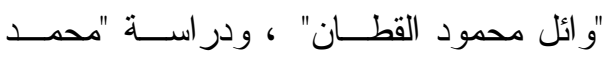

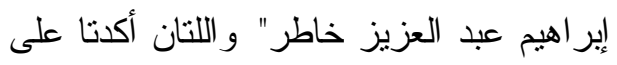

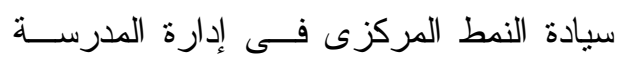
الثانوية ، ودر اسة "صلاح الدين عبد العزيـز الديز

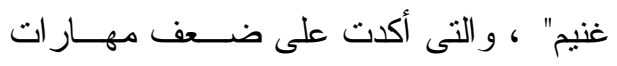

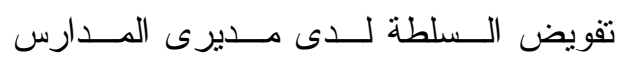

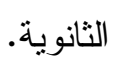

وربما يعود ما ســـق إلــى عوامــل

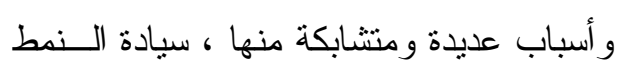

المركزى إدارة التعليم ككل ، و انعكاس هذا -

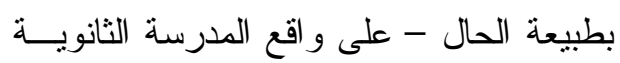

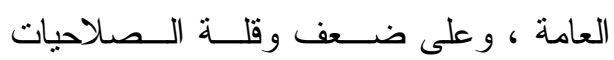

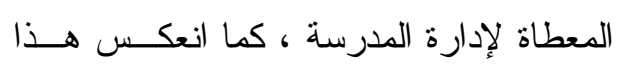

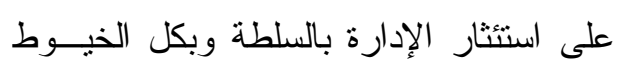

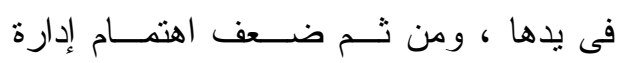

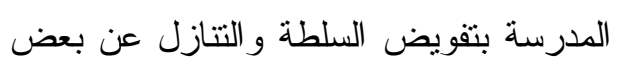

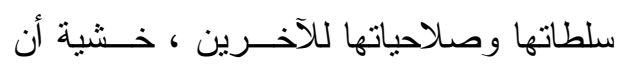

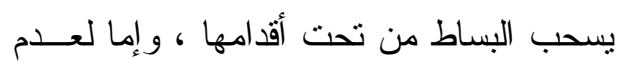

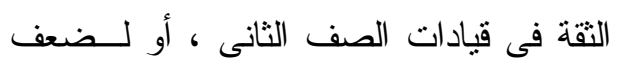

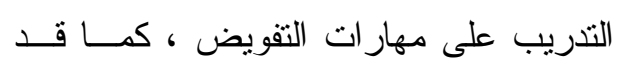
يعود ما سبق إلى أن معظم المعايير الحاكمة

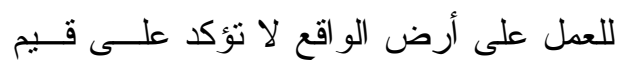

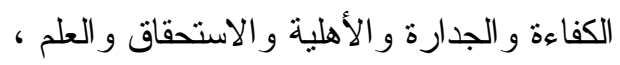

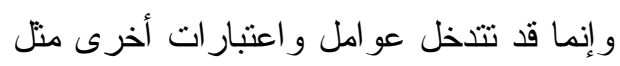

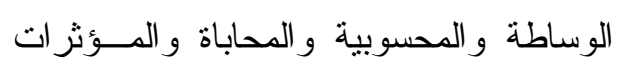
الثخصية فى تقسيم العمل وتوزيــع المهــام و المسئوليات.
- أن أعلى الاستجابات فى الاتجاه الإيجابى

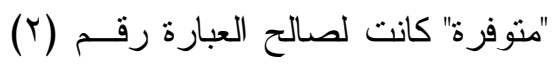
ومفادها "يثم تقسيم العمل داخل المدرسة بشكل موضوعى ومنطقى" حيث بلغـــت

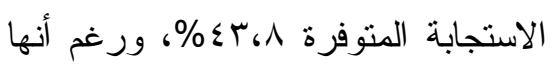

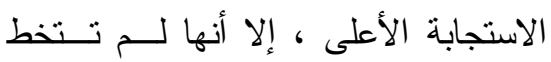

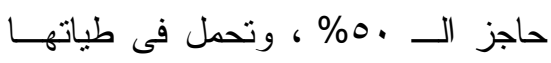

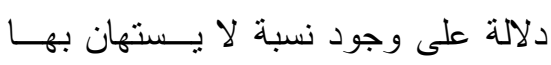

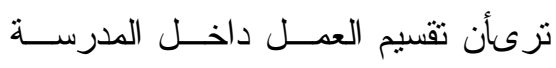

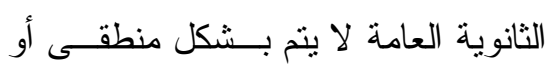

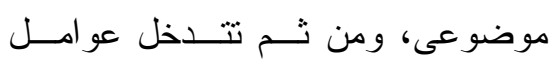
و اعتبار ات عديدة لا علاقة لها بالكفـــاءة و الجدارة والأهلية فى تقسيم العمل.

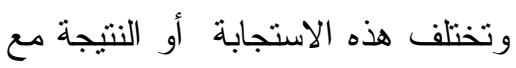

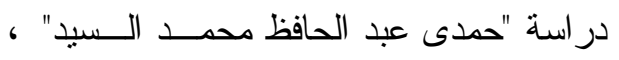
و التى أكدت على انتتار السلوكيات المرضية

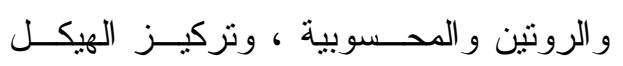

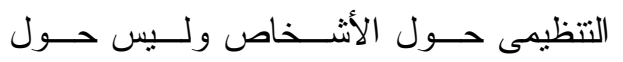

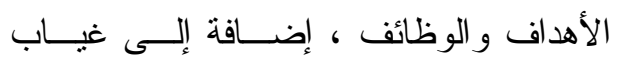
الموضو عية بدرجة كبيرة.

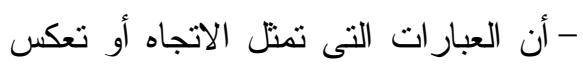

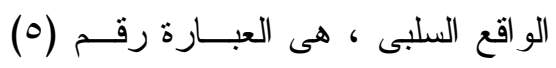

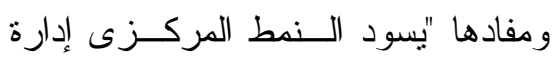

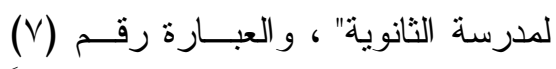
ومفادها "تعطى إدارة المدرسة اهنمامساً

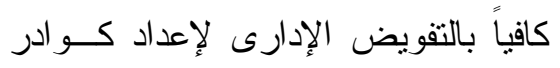

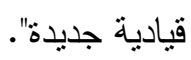




\section{r-النتائج الخاصة بالمحور الثالث "العلاقات" :}

يوضح الجدول التالى هذه النتائج كما يلى :

جدول (9) استجابات أفراد العينة على العبارات الخاصة بمحور العلاقات.

\begin{tabular}{|c|c|c|c|c|c|c|c|c|c|c|}
\hline الدلالة & مستوى & مربع كاى & الحستوسد & متوفرة & متوفرة & متوفيرة & العلية & والنسية & العبارات & p \\
\hline دال & 0.000 & $\begin{array}{r}164.71 \\
7\end{array}$ & 2.61 & 182 & 104 & 4 & 290 & التكر ار & \multirow{2}{*}{ 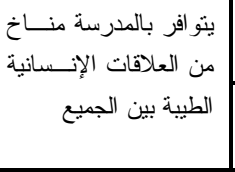 } & 1 \\
\hline & & & & 62.8 & 35.9 & 1.4 & 100 & النئبة & & \\
\hline دال & 0.000 & $\begin{array}{r}143.77 \\
9\end{array}$ & 2.57 & 170 & 114 & 6 & 290 & التكر ار & \multirow{2}{*}{ 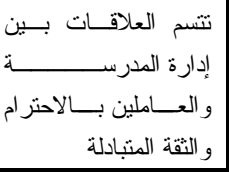 } & 2 \\
\hline & & & & 58.6 & 39.3 & 2.1 & 100 & النئبة & & \\
\hline دال & 0.000 & 86.283 & 2.44 & 163 & 93 & 34 & 290 & النكر ار & \multirow{2}{*}{ 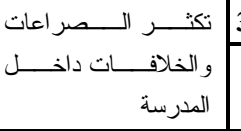 } & 3 \\
\hline & & & & 56.2 & 32.1 & 11.7 & 100 & النئبة & & \\
\hline دال & 0.008 & 9.607 & 2.14 & 121 & 89 & 80 & 290 & التكر ار & \multirow{2}{*}{ 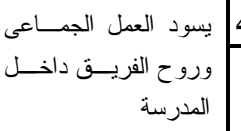 } & 4 \\
\hline & & & & 41.7 & 30.7 & 27.6 & 100 & المئوية & & \\
\hline دال & 0.000 & $\begin{array}{r}108.95 \\
9\end{array}$ & 2.32 & 111 & 161 & 18 & 290 & التكر ار & \multirow{2}{*}{ | } & 5 \\
\hline & & & & 38.3 & 55.5 & 6.2 & 100 & النئبة & & \\
\hline دال & 0.000 & 91.952 & 2.38 & 129 & 141 & 20 & 290 & التكر ار & \multirow{2}{*}{ 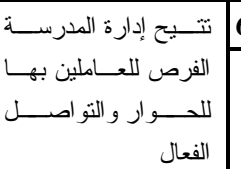 } & 6 \\
\hline & & & & 44.5 & 48.6 & 6.9 & 100 & النئبة & & \\
\hline دال & 0.000 & $\begin{array}{r}108.95 \\
9\end{array}$ & 2.32 & 111 & 161 & 18 & 290 & التكر ار & \multirow{2}{*}{\multicolumn{2}{|c|}{ 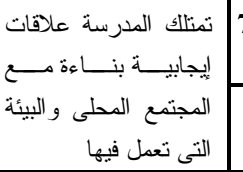 }} \\
\hline & & & & 38.3 & 55.5 & 6.2 & 100 & النئبة & & \\
\hline
\end{tabular}

يتضح من الجدول السابق ما يلى :

السلبى فى حقيقة الأمر ، وهى العبــارة

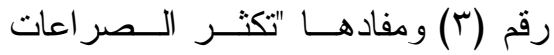

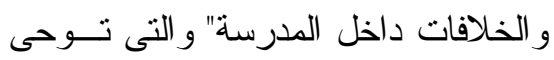

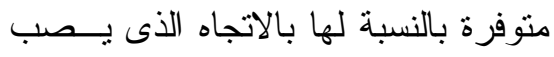

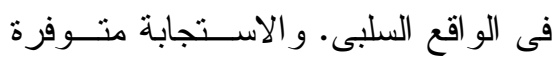

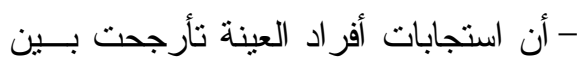

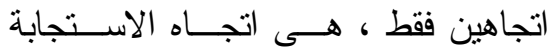

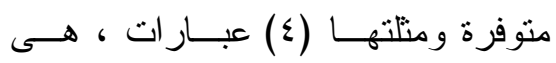

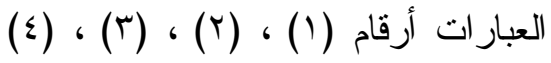

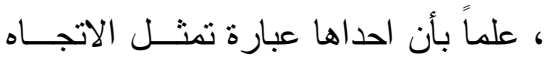


الضعف ، وتارة يحاولون تجميـلـ هــــا الو اقع وتتميقه خوفــاً علــى مر اكـــز هم و أماكنهم أو على الأقل صــــورتهم أمسـام

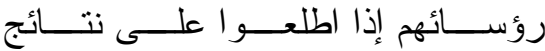

$$
\text { استجاباتهم. }
$$

وتختلف نتائج الاستجابات حول هــذا

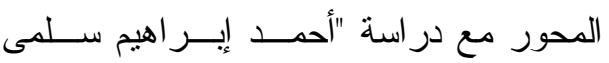

أرناؤط" ، و التى أكدت على ضعف لـ العلاقات الإنسانية بين المديرين و العاملين فى المدارس الثانوية و انخفاض الثقة بين القيادة و العاملين. كما أنالاستجابات فى الدر استة الحاليــة أظهرت سيادة العمل الجماعى وروح الفريق ، و هى نتيجة تختلف مــع در اســـة "إيمــان زغلول راغب النجار" ، والتى أكدت علـى سلبية المناخ المدرسى ، وضعف قيم العمـلـل بروح الفريق القائم على الرؤيـــة المــشتركة و العمل الجماعى. - تدل النتائج السابقة على كثرة الخلافـات و الصر اعات داخل المدرســـة الثانويـــة العامة ، وأن إدارة المدرسة الثانويــــة لا لاهله تثيح الفرص الكافية - إلى حـــ مـــا للعاملين للحوار و التو اصل الفعال ، كمــــا أن هناك ضعف فى مستوى الثفافية إلى حد ما ، ومع ذللك تتسم العلاقـات بــين إدارة المدرسة و العاملين بها بــالاحتر ام

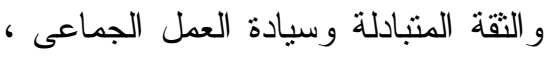
وتو افر مناخ مــن العلاقـات الإنـسانية الطيبة بين الجميع.

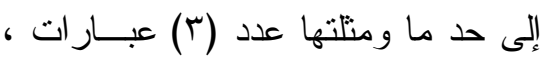

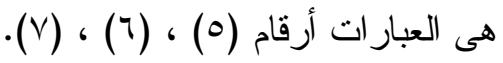
- أن أعلى الاستجابات فى الاتجاه الإيجابى "متوفرة" تمنتلت فى العبارة رقـم (1) ( ومفادها "يتو افر بالمدرســـة منـــاخ مـــن

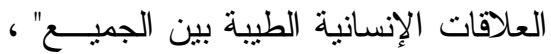
حيث أتت الاســتجابة متــوفرة بنـسبة

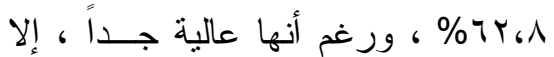
أنه ثمة ثتاقض واضتح فى الاستجابات

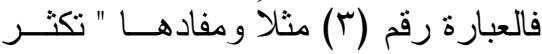
الصر اعات و الخلافات داخل المدرســـة" متحققــة علــى أرض الو اقــع وبنــسبة

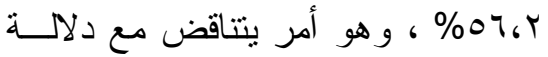
الاستجابة على العبارة رقم (1) ، ويؤكد ذلك أن العبارة رقم (Y) ومفادها "تثـسم العلاقات بين إدارة المدرسة و العــاملين

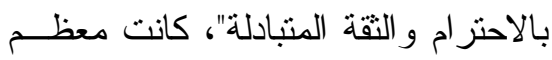

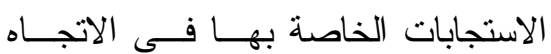

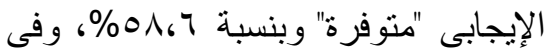
الوقت ذاته يلاحظ أن العبارة رقــم (o)

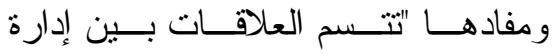

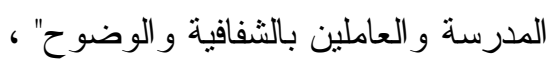
أتت معظم الاستجابات الخاصة بها فـى

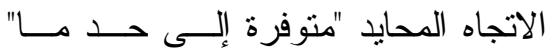

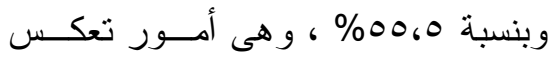
وجود حالة من التردد و التحفظ من قبــلـ

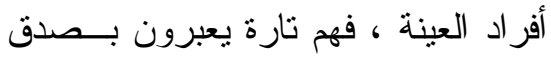
وشفافية عن الو اقعو الــــى بطبيعتـــهـ يموج بعديد مسن الـسلبيات ونـــواحى ولى 
ع -النتائج الخاصة بالمحور الر ابع "المكافآت والحوافز" :

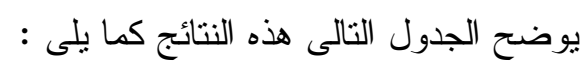

جدول (• 1) استجابات أفراد العينة على العبار ات الخاصة بمحور المكافآت.

\begin{tabular}{|c|c|c|c|c|c|c|c|c|c|c|}
\hline ألاد & مستوى الدلادة & قيمة مربع & الحستوسطى & متوفرة & متوفرة & متوفيرة & العيذ & والتكربة & العبارات & م \\
\hline دال & 0.000 & 38.51 & 1.72 & 66 & 78 & 146 & 290 & التكر ار & \multirow{2}{*}{ 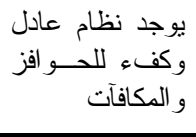 } & \multirow[t]{2}{*}{1} \\
\hline & & & & 22.8 & 26.9 & 50.3 & 100 & المئوية & & \\
\hline \multirow[t]{2}{*}{ دال } & 0.000 & 44.738 & 2.28 & 125 & 122 & 43 & 290 & التكر ار & \multirow{2}{*}{ وتوجد فرص كادية للترقىى } & \multirow[t]{2}{*}{2} \\
\hline & & & & 43.1 & 42.1 & 14.8 & 100 & المئوية & & \\
\hline \multirow[t]{2}{*}{ دال } & 0.000 & 149.51 & 1.43 & 26 & 73 & 191 & 290 & التكر ار & \multirow{2}{*}{ 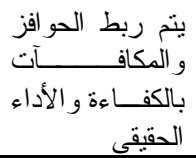 } & \multirow[t]{2}{*}{3} \\
\hline & & & & 9.0 & 25.2 & 65.9 & 100 & المئوية & & \\
\hline \multirow[t]{2}{*}{ دال } & 0.000 & $\begin{array}{c}105.77 \\
2 \\
\end{array}$ & 1.53 & 40 & 73 & 177 & 290 & التكر ار & \multirow{2}{*}{ 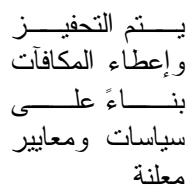 } & \multirow[t]{2}{*}{4} \\
\hline & & & & 13.8 & 25.2 & 61.0 & 100 & المئوية & & \\
\hline \multirow[t]{2}{*}{ دال } & 0.026 & 7.29 & 1.87 & 80 & 93 & 117 & 290 & التكر ار & \multirow{2}{*}{ 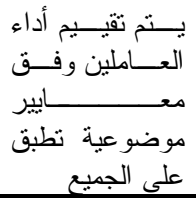 } & \multirow[t]{2}{*}{5} \\
\hline & & & & 27.6 & 32.1 & 40.3 & 100 & المئوية & & \\
\hline \multirow[t]{2}{*}{ دال } & 0.000 & 28.662 & 2.10 & 92 & 136 & 62 & 290 & التكر ار & \multirow{2}{*}{ 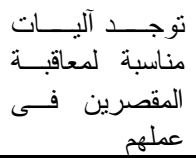 } & \multirow[t]{2}{*}{6} \\
\hline & & & & 31.7 & 46.9 & 21.4 & 100 & المئوية & & \\
\hline \multirow[t]{2}{*}{ دال } & 0.000 & 58.703 & 1.75 & 38 & 142 & 110 & 290 & التكر ار & \multirow{2}{*}{ 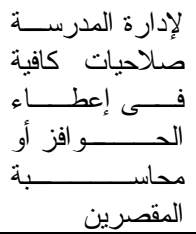 } & \multirow[t]{2}{*}{7} \\
\hline & & & & 13.1 & 49.0 & 37.9 & 100 & المئوية & & \\
\hline \multirow[t]{2}{*}{ دال } & 0.000 & 27.731 & 1.82 & 56 & 127 & 107 & 290 & التكر ار & \multirow[b]{2}{*}{ 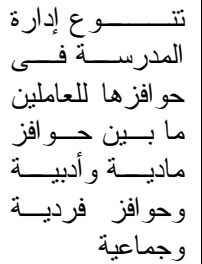 } & 8 \\
\hline & & & & 19.3 & 43.8 & 36.9 & 100 & المئوية & & \\
\hline
\end{tabular}




\section{يتضح من الجدول السابق ما يلى :}

الشأن ، و لا توجد لمدير المدرسة صلاحيات كافية في هذا الصدد.

ويمكن أن تعزى هذه النتائج الــسلبية

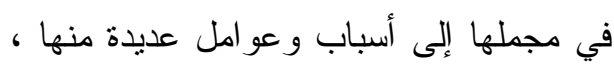

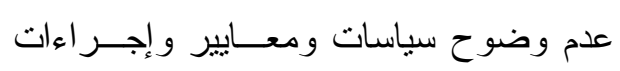
اعطاء الحو افز و المكافآت ، و وعدم وجود نظام

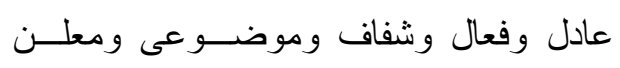

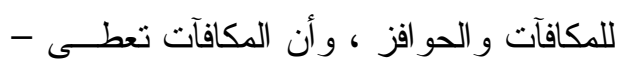
للأسف- للمجتهر وغير المجتهد على السواء

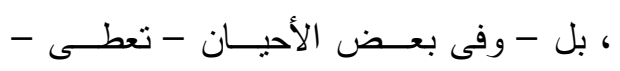

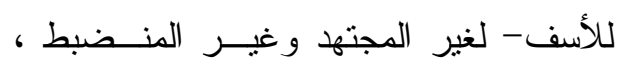
ويحرم منها المجتهـ و المنــضبط و المتميــز

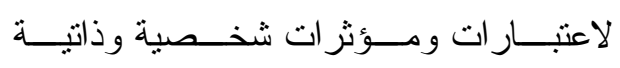

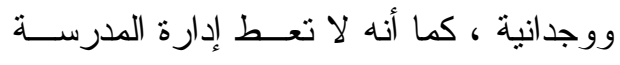

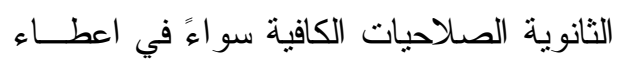

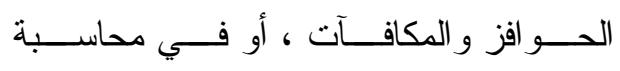
المقصرين ، كما تتسم تقارير الأداء - غالبــاً

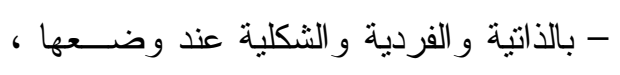

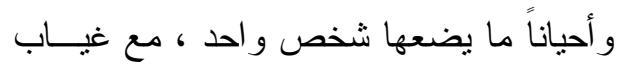

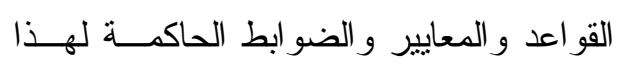
الأمر الحيوى ، مما يــؤدى إلــى الـشعبور

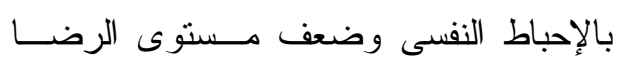

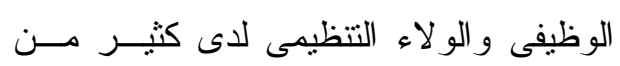
العاملين بالمدر اس الثانوية العامة.

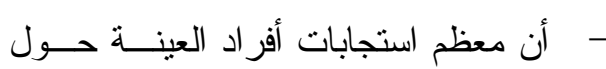
عبار ات هذا المحور رنحت نحو الاتجاه

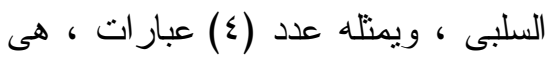

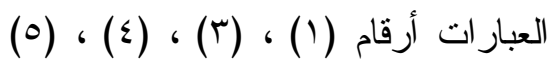

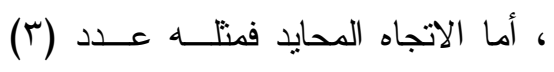

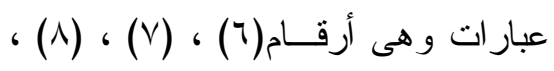

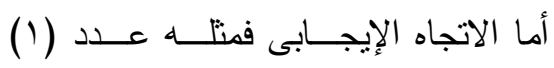
عبارة فقط هى العبارة رقم (Y). - - فى تقدير البحث الحالى أن هذه النتــائج

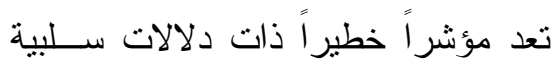

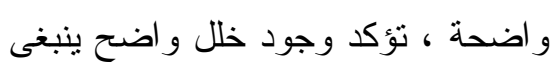

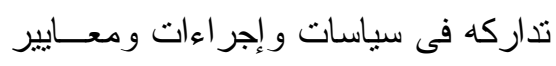

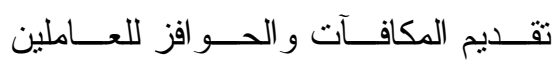
بالمدارس الثانوية العامة.

وتتفق هذه النتائج مع نتــائج در اســـة

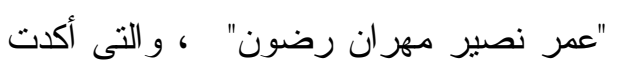

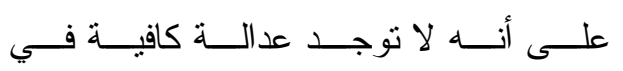

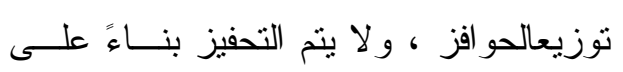

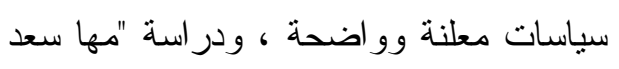

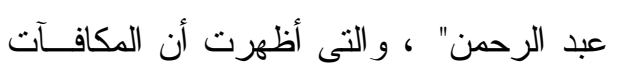

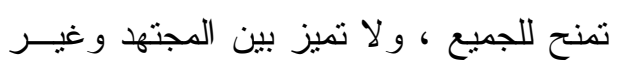

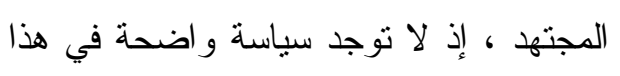




\section{•-النتائج الخاصة بالمحور الخامس "(القيادة" : \\ يوضح الجدول التالى هذه النتائج كما يلى :}

جدول (11) استجابات أفراد العينة على العبارات الخاصة بمحور القيادة.

\begin{tabular}{|c|c|c|c|c|c|c|c|c|c|c|}
\hline الالالة & مستوي & قيمة مربع & الحستوسط & متوفرة & متوفرة & متوفيرة & العلية & والتئسبة & العبارات & م \\
\hline دال & 0.000 & 100.993 & 2.41 & 136 & 138 & 16 & 290 & التكر ار & \multirow{2}{*}{ 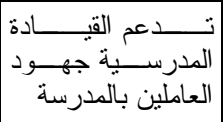 } & \multirow[t]{2}{*}{1} \\
\hline & & & & 46.9 & 47.6 & 5.5 & 100 & المئوية & & \\
\hline \multirow[t]{2}{*}{ دال } & 0.000 & 123.007 & 2.48 & 148 & 134 & 8 & 290 & التكر ار & \multirow{2}{*}{ 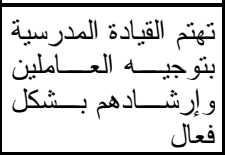 } & \multirow[t]{2}{*}{2} \\
\hline & & & & 51.0 & 46.2 & 2.8 & 100 & المئوية & & \\
\hline \multirow[t]{2}{*}{ دال } & 0.000 & 42.234 & 2.13 & 92 & 144 & 54 & 290 & التكر ار & \multirow{2}{*}{ 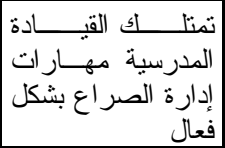 } & \multirow[t]{2}{*}{3} \\
\hline & & & & 31.7 & 49.7 & 18.6 & 100 & المئوية & & \\
\hline \multirow[t]{2}{*}{ دال } & 0.000 & 44.221 & 2.19 & 102 & 140 & 48 & 290 & التكر ار & \multirow{2}{*}{ 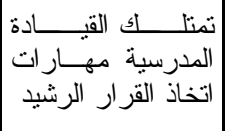 } & \multirow[t]{2}{*}{4} \\
\hline & & & & 35.2 & 48.3 & 16.6 & 100 & المئوية & & \\
\hline \multirow[t]{2}{*}{ دال } & 0.000 & 59.303 & 2.20 & 99 & 149 & 42 & 290 & التكر ار & \multirow{2}{*}{ 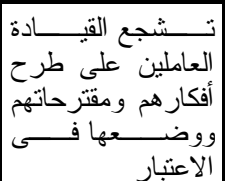 } & \multirow[t]{2}{*}{5} \\
\hline & & & & 34.1 & 51.4 & 14.5 & 100 & المئوية & & \\
\hline \multirow[t]{2}{*}{ دال } & 0.001 & 13.434 & 1.99 & 80 & 126 & 84 & 290 & التكر ار & \multirow{2}{*}{ 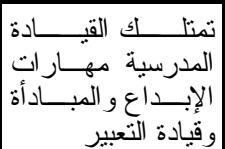 } & \multirow[t]{2}{*}{6} \\
\hline & & & & 27.6 & 43.4 & 29.0 & 100 & المئوية & & \\
\hline \multirow[t]{2}{*}{ دال } & 0.000 & 20.903 & 2.03 & 83 & 133 & 74 & 290 & التكر ار & \multirow{2}{*}{ 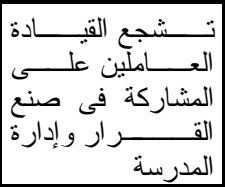 } & \multirow[t]{2}{*}{7} \\
\hline & & & & 28.6 & 45.9 & 25.5 & 100 & المئوية & & \\
\hline \multirow[t]{2}{*}{ دال } & 0.000 & 25.372 & 2.02 & 79 & 137 & 74 & 290 & التكر ار & \multirow{2}{*}{ 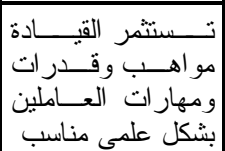 } & \multirow[t]{2}{*}{8} \\
\hline & & & & 27.2 & 47.2 & 25.5 & 100 & المئوية & & \\
\hline \multirow[t]{2}{*}{ غير } & 0.436 & 1.662 & 2.00 & 91 & 107 & 92 & 290 & التكر ار & \multirow{2}{*}{ 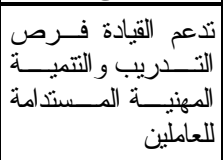 } & \multirow[t]{2}{*}{9} \\
\hline & & & & 31.4 & 36.9 & 31.7 & 100 & المئوية & & \\
\hline \multirow[t]{2}{*}{ دال } & 0.000 & 84.048 & 2.25 & 103 & 157 & 30 & 290 & التكر ار & \multirow{2}{*}{ 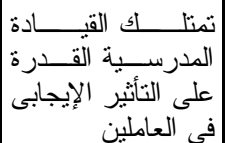 } & \multirow[t]{2}{*}{10} \\
\hline & & & & 35.5 & 54.1 & 10.3 & 100 & المئوية & & \\
\hline
\end{tabular}


يتضح من الجدول السابق ما يلى :

الإدارية للقيادات المدرسية ، ودر اســـة

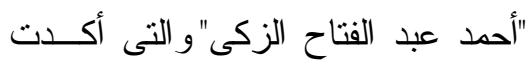

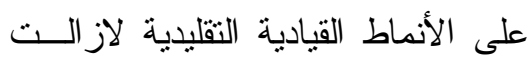
سائدة ، و غياب الممارسات الديمقر اطية

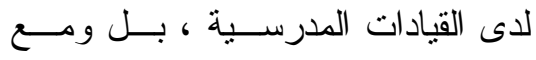

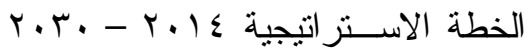

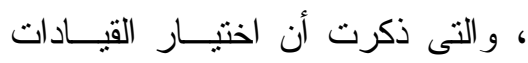

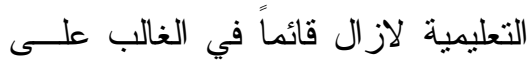
الأقدمية وليس الكفاءة.

بل وبنظرة فاحصة متعمقة متأنية لهذه الاستجابات - حتى وإن ظهرت محايدة - إلا فئل أنها في حد ذاتها ، تدل على وجود خلل فـي

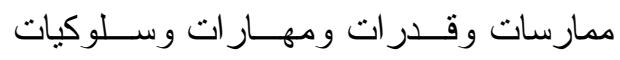
القيادة المدرســية ، ســـواءً مهــار ات إدارة

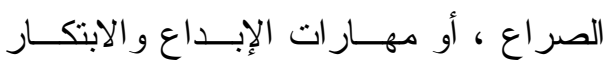

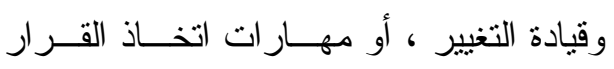
الرشيد، أو مهار ات استثمار مواهب وقاد وقدرات العاملين و المرؤوسين ، أو تشجيع العـاملين على المشاركة فــي صـــنع القــر ار و إدارة المدرسة وتدعيم فرص التـدريب و التتميــة المهنية لهم.

צ-النتائج الخاصة بالمحور السادس "الآليات

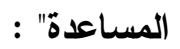
يوضح الجدول التــالى هـــــ النتــائج كما يلى :

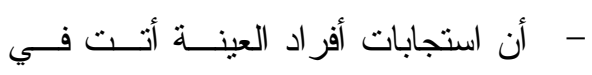

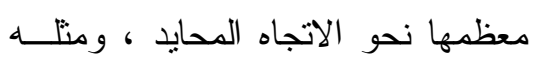

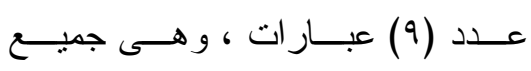

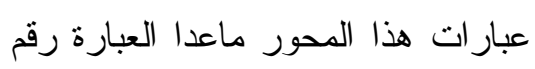

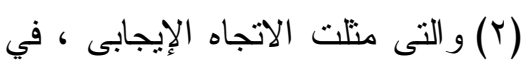

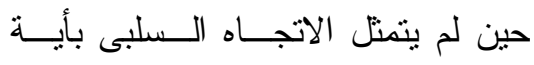
عبارة. - مبن. - - وفى تقدير البحـــث الحــالى أن غلبـــة

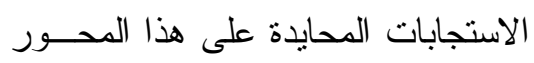
أمر منطقى وطبيعى وربما كان منوقعاً

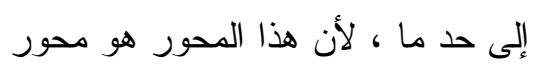

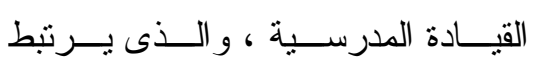

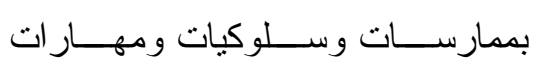
وقدرات القيادة المدرسية ، و لأن معظم

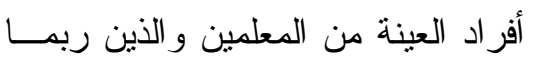
يخافون من الإدلاء باستجابات سـلبية

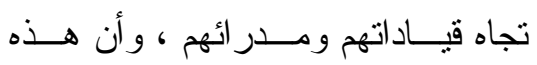
الاستجابات يمكن - ولو بنسبة ضــئيلة

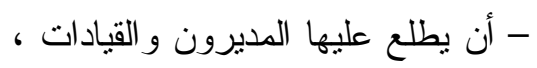

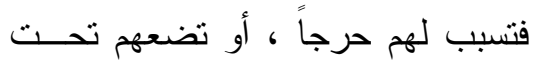
المساءلة و الرقابة ، أو تحت الإضطهاد

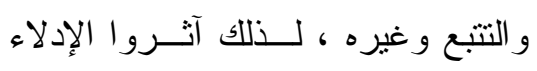

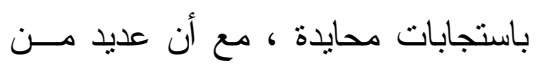

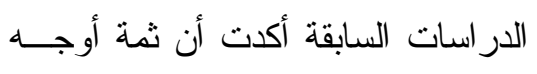

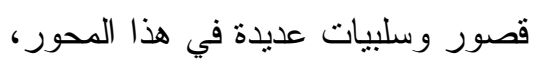
مثل دراسة "أسماء أحمد محمد عثمان"

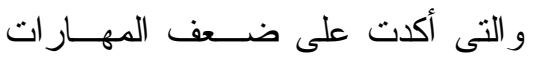




\begin{tabular}{|c|c|c|c|c|c|c|c|c|c|c|}
\hline & مساعد & الآليات & لة بمحر & الخاص & ـ العبار ال & لعينة & أفر ال & تجاب & جدول (Y I) & \\
\hline الدالة & الالالة & قيمة مربع & الحستابى & متوفرة & متوفرة ما إلى & متوفيرة & الكلينة & والنكبية & العبارات & 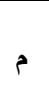 \\
\hline \multirow[t]{2}{*}{ دال } & 0.000 & 72.048 & 2.09 & 77 & 163 & 50 & 290 & التكر ار & \multirow{2}{*}{ 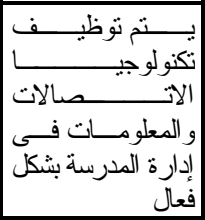 } & \multirow{2}{*}{1} \\
\hline & & & & 26.6 & 56.2 & 17.2 & 100 & المئوية & & \\
\hline \multirow[t]{2}{*}{ دال } & 0.000 & 33.317 & 2.00 & 73 & 143 & 74 & 290 & التكر ار & \multirow{2}{*}{ 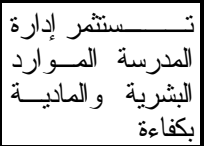 } & \multirow[t]{2}{*}{2} \\
\hline & & & & 25.2 & 49.3 & 25.5 & 100 & المئوية & & \\
\hline \multirow[t]{2}{*}{ غير دال } & 0.254 & 2.738 & 1.96 & 97 & 85 & 108 & 290 & التكر ار & \multirow{2}{*}{ 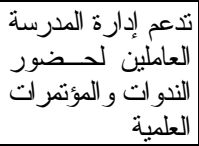 } & \multirow[t]{2}{*}{3} \\
\hline & & & & 33.4 & 29.3 & 37.2 & 100 & المئوية & & \\
\hline \multirow[t]{2}{*}{ دال } & 0.000 & 33.793 & 1.72 & 60 & 90 & 140 & 290 & التكر ار & \multirow{2}{*}{ 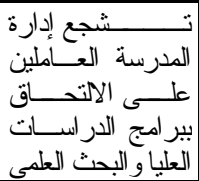 } & \multirow[t]{2}{*}{4} \\
\hline & & & & 20.7 & 31.0 & 48.3 & 100 & المئوية & & \\
\hline \multirow[t]{2}{*}{ دال } & 0.000 & 33.234 & 1.74 & 51 & 113 & 126 & 290 & التكر ار & \multirow{2}{*}{ 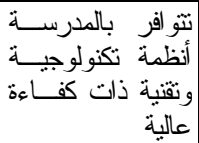 } & \multirow[t]{2}{*}{5} \\
\hline & & & & 17.6 & 39.0 & 43.4 & 100 & المئوية & & \\
\hline \multirow[t]{2}{*}{ دال } & 0.000 & 83.924 & 2.19 & 91 & 163 & 36 & 290 & التكر ار & \multirow{2}{*}{ 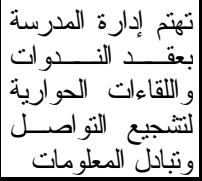 } & \multirow[t]{2}{*}{6} \\
\hline & & & & 31.4 & 56.2 & 12.4 & 100 & المئوية & & \\
\hline \multirow[t]{2}{*}{ دال } & 0.000 & 79.476 & 2.03 & 66 & 168 & 56 & 290 & التكر ار & \multirow{2}{*}{ 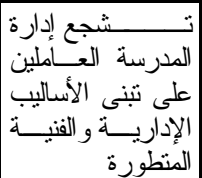 } & \multirow[t]{2}{*}{7} \\
\hline & & & & 22.8 & 57.9 & 19.3 & 100 & المئوية & & \\
\hline \multirow[t]{2}{*}{ 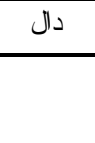 } & 0.000 & 25.517 & 1.86 & 60 & 130 & 100 & 290 & التكر ار & \multirow{2}{*}{ 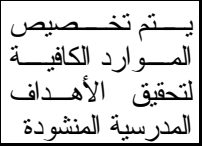 } & \multirow[t]{2}{*}{8} \\
\hline & & & & 20.7 & 44.8 & 34.5 & 100 & المئوية & & \\
\hline \multirow[t]{2}{*}{ دال } & 0.000 & 94.89 & 2.27 & 103 & 161 & 26 & 290 & التكر ار & \multirow{2}{*}{ 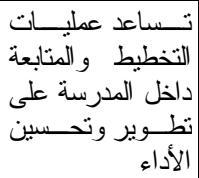 } & \multirow[t]{2}{*}{9} \\
\hline & & & & 35.5 & 55.5 & 9.0 & 100 & المئوية & & \\
\hline \multirow[t]{2}{*}{ دال } & 0.000 & 157.766 & 2.26 & 88 & 188 & 14 & 290 & التكر ار & \multirow{2}{*}{ 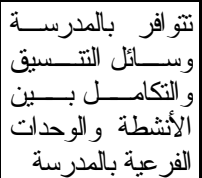 } & 10 \\
\hline & & & & 30.3 & 64.8 & 4.8 & 100 & المئوية & & \\
\hline
\end{tabular}


يتضح من الجدول السابق ما يلى :

وربما تعزى هذه النتائج السلبية إلــى

عو امل و أسباب عديدة ومتذاخلة منها ، ضعف المخصصات المالية اللازمة لتحقيق الأهداف المدرسية المنشودة ، ضعف الاستثمار الأمنل

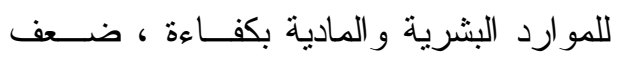

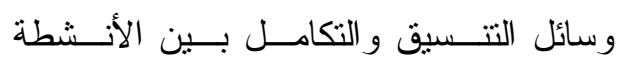
و الوحدات الفرعية بالمدرسة ، ضعف نتجيع إدارة المدرسة الثانوية للعــاملين و المعلمـين على تنبى الأساليب الإدارية و الفنية المتطورة و الحديثة.

كما يعزي مــا ســبق الــي تخــبط

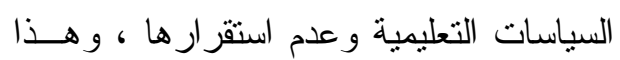
يتضح من استمرار المشكلات التي يعانيهــا التعليم قبل الجامعي ، بل وتفاقمها في كثيـر

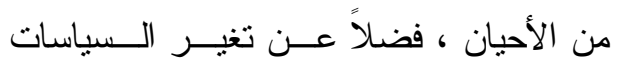
التعليمبة بتغير الوزر اء (rrr) .

يضاف إلى ما سبق ضـــــف تــشجيع

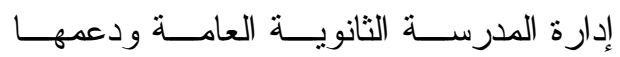

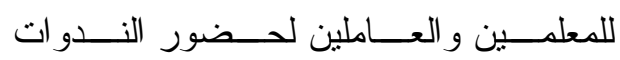

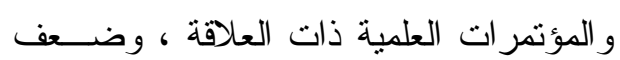

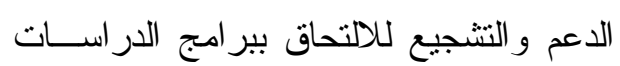
العليا ، بل إن الواقع يؤكد أن إدارة المدرســـة الثانوية العامة تضع العقبات و العر اقيل - في بعض الأحيان - أمام المنتسبين إلبها في هذا

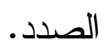

- أن معظم استجابات أفراد العينة أتت في الجات

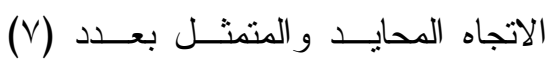

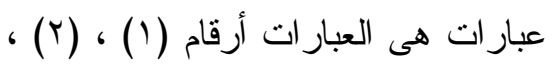

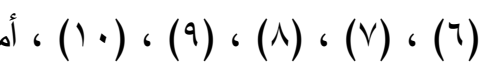

الاتجاه السلبى "غير متوفرة" فمثله عــدد

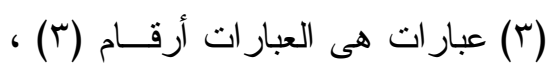

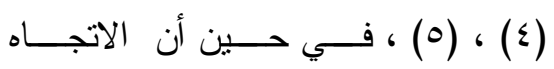
الإيجابى "متوفرة" لم تمثنله أية عبارة. - في تقدير البحث الحالى أن هذه النتــائج

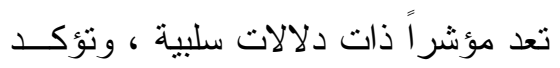
وجود خلل واضتح في مجــال الآليــات

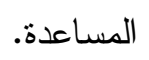

ونتقق هذه النتائج مع در اسة "أســماء

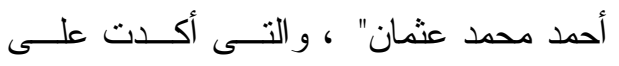
ضعف تشجيع المديرين للعاملين و المعلمـين على البحث عن فرص جديدة للنمو و التتميــة المهنية وتمكينهم من حــضور المــؤتمر ات و اللقاءات و الاجتماعات التزبويــــة ، وكــذلك در اسة "أحمد نجم الدين أحمد عيــداروس" ، وله ودر اسة "عبد الخالق فؤاد محمد عبد الخــالق"

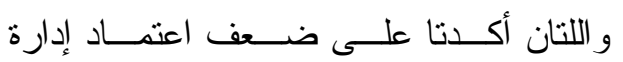
المدرسة الثانوية على تكنولوجيا الاتـصالات و المعلومات وتوظيفهــــا ، ونـــــرة مو اكبـــة

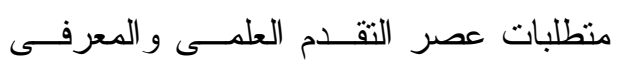
و التكنولوجى. 
V-النتائج الخاصــة بــالفروق الإحـصائية

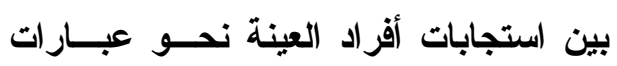
الاستبيان :

لحساب دلالة الفروق الإحصائية بـين

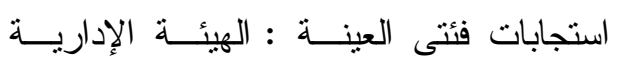

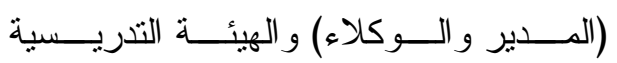

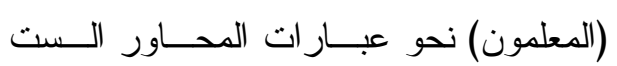

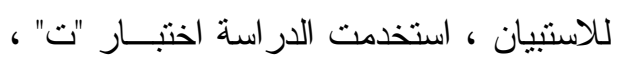

ويتضح ذلك من الجدول التالى :

جدول (r I I) : دلالة الفروق الإحصائية بين استجابات أفراد العينة.

\begin{tabular}{|c|c|c|c|c|c|c|}
\hline \multirow{2}{*}{ مستوى الدلالة } & \multirow{2}{*}{ قيمة } & \multicolumn{2}{|c|}{ المديرون (ن= · · ) } & \multicolumn{2}{|c|}{ المعلمون (ن= . بr } & \multirow[b]{2}{*}{ الاستبيان } \\
\hline & & الالحعراف & المتوسط & الالمعراف & المتوسط & \\
\hline 0.000 & 5.234 & 3.16155 & 20.7333 & 4.33910 & 17.4000 & الأول \\
\hline 0.000 & 5.686 & 3.32960 & 22.5000 & 5.02639 & 18.6154 & الثانى \\
\hline 0.000 & 5.635 & 1.61210 & 18.5667 & 3.14603 & 16.5769 & الثالث \\
\hline 0.002 & 3.339 & 4.59648 & 17.1000 & 3.22425 & 14.2192 & الر ابع \\
\hline 0.000 & 6.404 & 3.87165 & 26.1000 & 4.82478 & 21.1846 & الخامس \\
\hline 0.000 & 7.306 & 2.80394 & 24.0000 & 4.78530 & 19.6769 & السادس \\
\hline
\end{tabular}

يتضح من الجدول السابق ما يلى :

- يرى البحث ان هذا أمر منطقى وطبيعسى

إلى حد كبير لأكثر من سبب منها :

• صغر حجم عينة المــديرين والــوكلاء

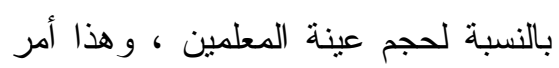

منطقى و لا دخل للبحث فيه ، لأنه فـي وهي

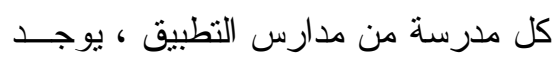

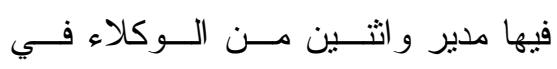

كما أن معظم المدارس الثانوية العامة

لا تتو افر بها أنظمة تكنولوجية وتقنية منطورة و عصرية وذات كفاءة عالية ، وما هو موجود

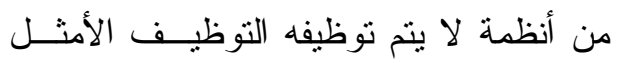
سواءً في التـــدريس والــتعلم أو فـــي إدارة

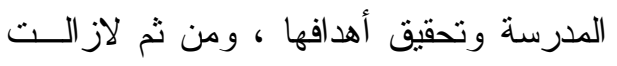
المدرسة الثانوية العامة تدار - إلى حد كبيـــر - بالثكل وبالأساليب التقليدية الروتينية. 
عو امل ومتغير ات عديـــدة تعـــد القبـــادة

$$
\text { المدرسية مجرد متغير و احد منها. }
$$

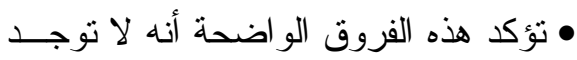

رؤية موحدة عبر تعدديـــة المــستويات

الإدارية و التتظيمية و التدريـسية بــشأن

الأداء التتظيمى بالمدرسة الثانوية العامة ، فالإدارة المدرسية في و ادٍ و المعلمــون في وادٍ آخر ، حيث لا يوجد نتــاغم أو

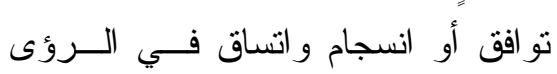
و الأفكار بثأن الو اقع ، وبالتأكيد ينعكس

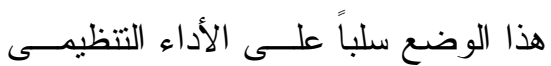
الفعلى بالمدارس الثانوية العامة.

وبنظرة إجمالية عامـــة لواقـــع التــشخيص

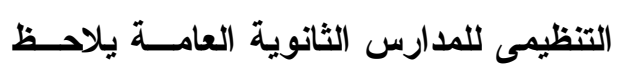
ما يلى : التطليحى

- أن العبار ات المؤكدة التــى حـــازت علــى

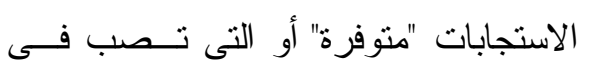
اتجاه الواقع الإيجابى بلغـــت (T) عبــارة فقط وبنسبة مب \% \% و هى نسبة ضئيلة

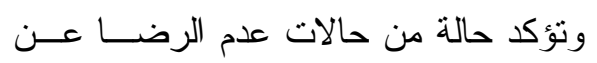

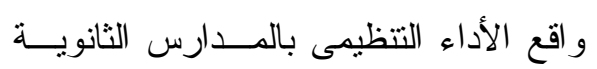
العامة فى أبعاده الست المحددة.

- أن معظد الاستجابات على العبار ات بالنسبة

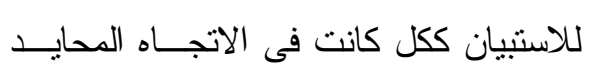
و عددها (YV) عبارة وبنـسبة \% ، و هى نسبة تحمل دلالات عديدة ، منها حالة الضبابية و الغموض وعـــدم اليقـين
المتوسط ، بينما يوجد عدد كبيـر مــن

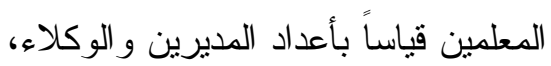
ففى إحدى المدارس مثنلاً تم التطبيق على عدد ( ) مدير وعـدد ( ) وكيـل مدرسة ، في حين تم التطبيق علي عـدد

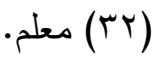

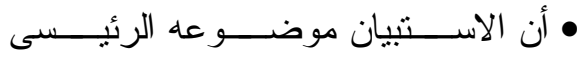
"النتخيص التتظيمى" ، ويدور في مجمله حول محاور و أبعاد ذات علاقة و اضحة ومباثرة بممارسات ومهـــار ات الهيئــة الإدارية ، ومن ثم كانت معظم استجابات

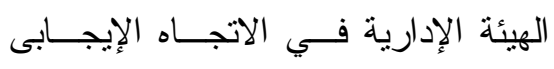
بالنسبة لهم ، ومحاو لاتهم إعطاء صورة الإدة الهاء إيجابية ومثالية ومنمقة عن الو اقع ، خوفاً من أن تؤثز النتائج أو استجاباتهم علــى ولئه مر اكز هم الوظيفية ، أو وقوعهم تحـــت لتون المساءلة و الرقابة. • يؤكد ما سبق أن الفروق بين متوســطي استجابات أفر ادالعينة من الهيئة الإداريـــة منية و الهيئة التدريسية بلغت ذروتها لـصالح الهيئة الإدارية في محور "القيادة" وهــــ

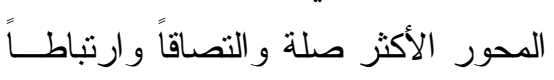
بالهيئة الإدارية ، حيث بلغ الفرق بو، ك لصالح الهيئة الإداريـــة مــن المــديرين و الوكلاء ، في حين كان الفارق أقل فـي محورى العلاقات الإنسانية و المكافــآت و الحو افز ، و التى تتشابلك وتتداخل فيهــا 
• ضعف مشاركة العاملين بالمدرسة فـى

$$
\text { صنع القرار و إدارة المدرسة. }
$$

• كثرة الــصر اعات و الخلافــات داخــلـ

$$
\text { المدرسة. }
$$

• ضعف مستوى الثفافية و الوضوح فـى العلاقات بين إدارة المدرسة و العـاملين

• لا يتو افر نظام عادل وكفء وموضوعى

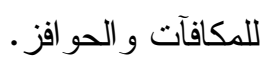

• ضعف ربط المكافآت و الحو افز بـالأداء

$$
\text { الحقبقى. }
$$

• لا يتم التحفيز و إعطاء المكافآت بناءً على

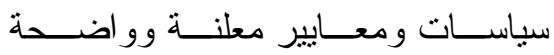

$$
\text { للجميع. }
$$

• لا يتم تقييم الأداء وفق معايير موضوعية تطبق على الجميـع وتـــنبط بـــالأداء

$$
\text { الحقيقى. }
$$

• ضعف امتلاك القيادة المدرسية - الي حد ما - لمهار ات الإبداع و المبادأة وقيـادة

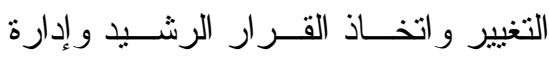

$$
\text { الصر اع بشكل فعال. }
$$

• لا تدعم إدارة المدرسة الثانوية العـاملين

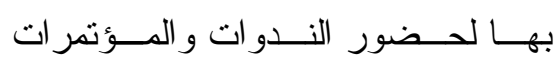
العلمية.
وعدم وضوح الرؤيسـة ، و الخــوف مـن

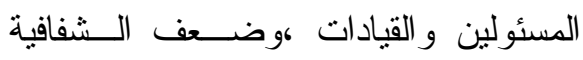
والثقة، كما أنها تحمل دلالات سلبية للواقع الحقيقى. - أن العبار ات التى حازت على الاســتجابات

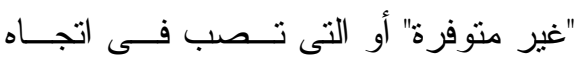

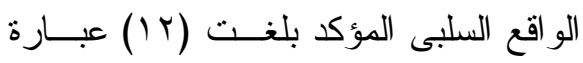

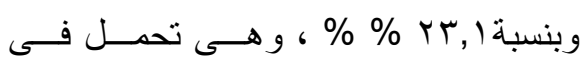

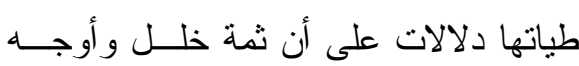

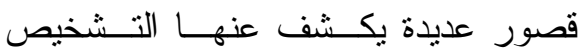

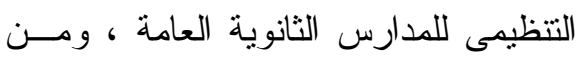
أبرز نقاط الضعف و السلبيات ما يلى : • تتسم أهداف المدرسة الثانويـــة العامـــة

$$
\text { بالغموض و عدم الوضوح. }
$$
• لا يتم ترجمة رؤية المدرسة ورســالتها

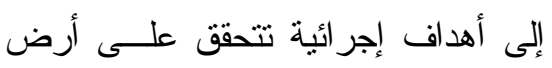
الو اقع. • ضعف مشاركة العاملين بالمدرسة - الي حد ما - فى صياغة رســالة المدرســة و أهدافها. • سيادة النمط المركزى فى إدارة المدرسة

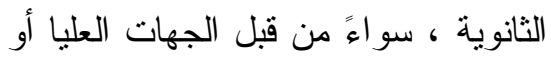
حتى داخل إدارة المدرسة الثانوية نفسها.

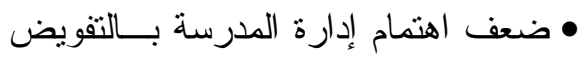
الإدارى لإعداد كو ادر قيادية جديدة. 


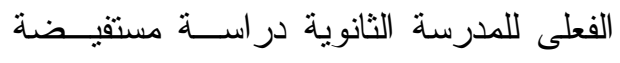

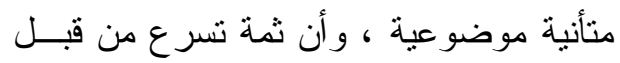

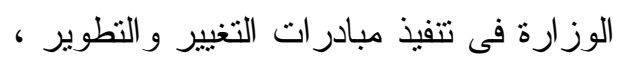
وأن مبادرات التطوير و الإصلاح لم تلق حظاً كافياً من التهيئة و الدر اسة و الاستعداد و النزول

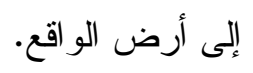

الخطـــوة الخامـسـة : بعــض الإجــر اعات

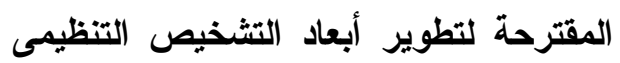
بالمدارس الثاتوية العامة :

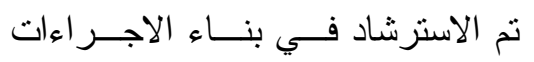

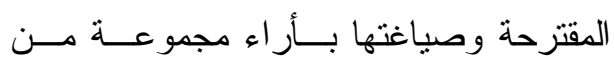

المحكمين المتخصصين ( ملحق رقم ا ) ) . تتضمن الإجراءات المقترحة ما يلى : أ-أهداف الإجراءات المقترحة : تهـف الإجــر اءات المقترحسـة إلـى لـى ما يلى : أ- ا- تطوير وتحسـسين أبعــاد التـشخيص

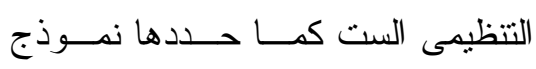
ويسبورد ، وذللك مـن خــلال تقــديم

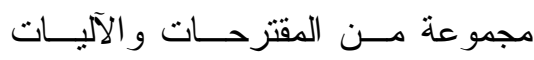

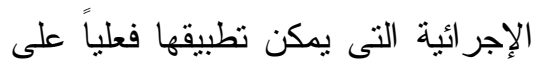

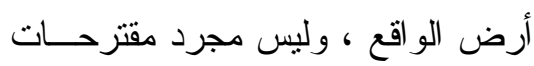

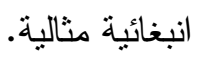

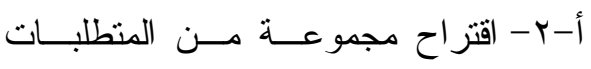
و الضمانات الأساسية اللازمـــة لنجـــاح الإجر اءات المقترحسـة لتطــــير أبعــاد
• لا تشجع إدارة المدرسة الثانوية العاملين بها على الالتحاق ببر امج الدراسات العليا

$$
\text { و البحث العلمى. }
$$

• ضعف توظيف تكنولوجيــا الاتـصالات و المعلومات فى إدارة المدرسة الثانوية. • ضعف المو ارد المالية و المادية الكافيـــة

$$
\text { لتحقيق الأهداف المنشودة. }
$$

• ندرة وجود أنظمة تقنيــة وتكنولوجيـــة

ومعلوماتية منطورة وذات كفاءة عالية.

وفى إطار ما سبق يتــساءل البحــث

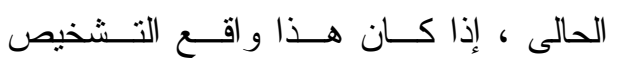

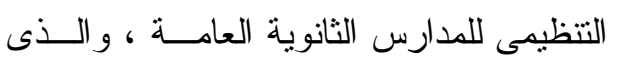
يحمل فى طياته جوانب سلبية عديدة ، فكيف

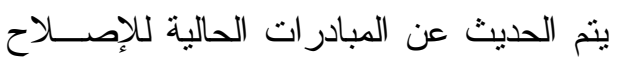

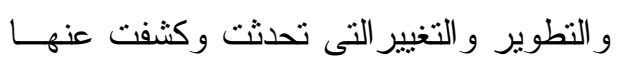

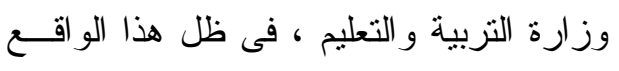

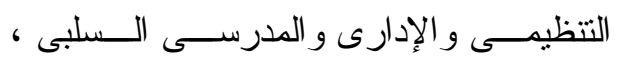

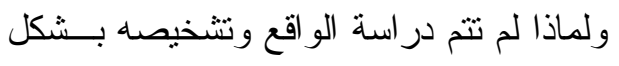

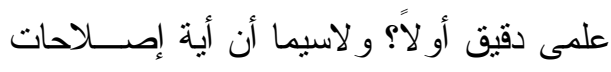

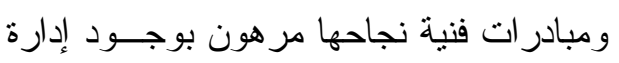

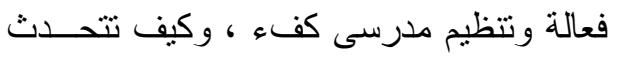
وز ارة التزبية و التعليم عن تطبيق التابلت مثناً

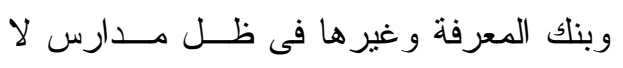
تتو افر بها أنظمة تقنية وتكنولوجية ومعلوماتية

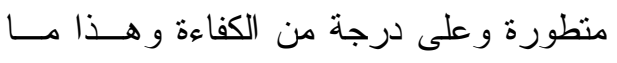

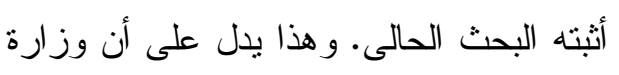

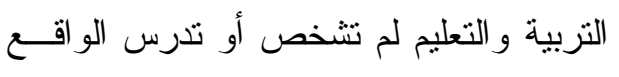


بالضرورة - إلى زيادة معدلات فـشنل

$$
\text { مبادر ات التغيير و الإصلاح. }
$$

ب-乏 - ان أية إصلاحات أو تغيير ات يقترح

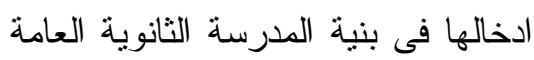

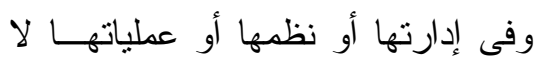
تتطلق من تــشخيص دقيــق وشـــامل

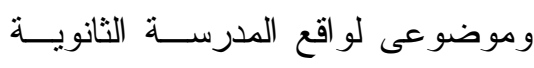
العامة ، محكوم عليها بالفنشل مسبقاً.

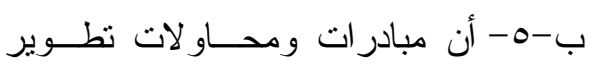

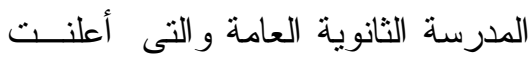

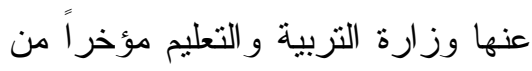

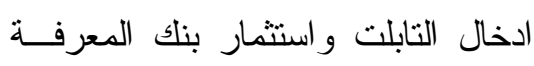
وتغيير نظام الثانوية العامة وتغيير نظم

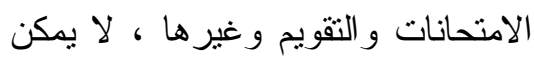

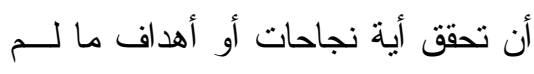

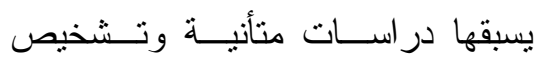
تتظيمى دقيق للو اقع.

ب-7- أن ثمة علاقة أكيدة ووثيقــــة بــين التشخيص التنظيمى وكافــة العمليــات

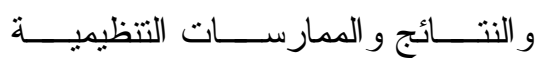

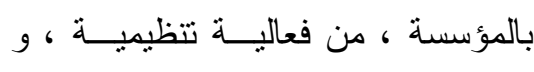

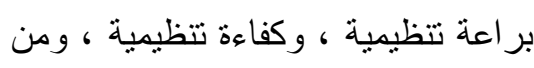

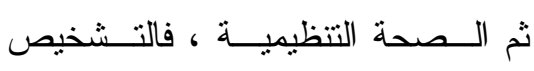
التنظيمى أساس الصحة التتظيمية. ب-V- أن ثمة علاقة وطيدة بين النشخيص التنظيمى السديد واتخاذ القرار الرشيد.
التشخيص التنظيمى للمدرسة الثانويــة العامة.

أ-ب- تحسين الأداء التتظيهـي بالمــدارس

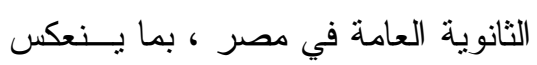
علي تحقيق أهدافها العامة .

ب-الاعتبــــــار ات و المنطلة العــــات الحاكمـــــة للإجر اءات المقترحة :

تستند الإجر اءات المقترحة لمجموعــة

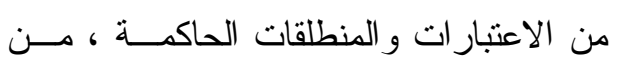
أهمها ما يلى : الاعبارات

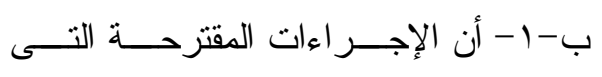

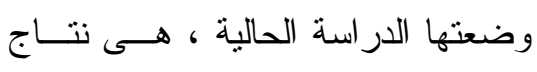

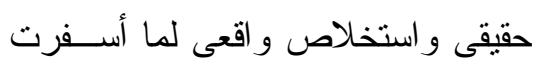
عنه هذه الدر اسة من نتــائج ، ســــواءً

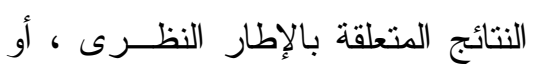

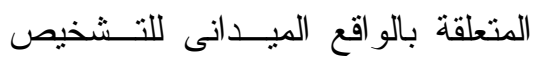
التنظيمي للمـــدارس الثانويـــة العامـــة بمحافظة الثرقية. ب-r- أن التنخيص التظظيمى يعد المفتاح

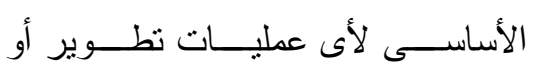

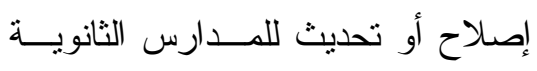
العامة.

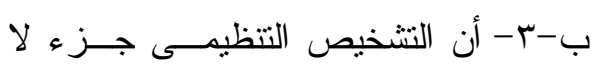

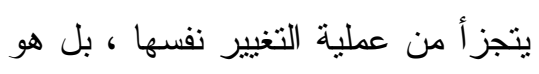
أساس عمليات إدارة التغيير ، وأن أيـــة

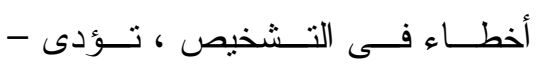


ب-r ا - أن التشخيص التظظيمى الجيد يجب

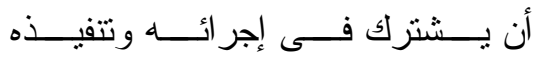

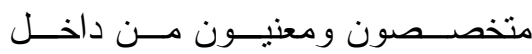

المنظمة ومن خارجها بشكل متــوازن

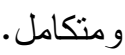

ب-س ا - أن ثمة معايير ومهار ات وضو ابط رئيسية من الضروري أن ثتو افر فـى

القائمين بالتشخيص ، سو اءً من حيــــ

الكفاءة المهنية و التتظيمبـــة و المعرفيــة

و المنهجية ، أو من حيث القدرة علىى وله

التحاور مع الجميع وبدون صــر اع أو أو هـئ

مشكلات ، أو القدرة على كـسب ثمـــة

الأطر اف المعنية ، إضافة إلى الدقة فى

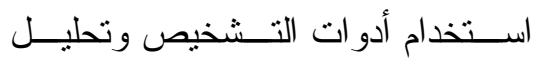

نتائجه و الربط بين مختلــف البيانــات

$$
\text { و المعلو مات. }
$$

ج- الإجراءات المقترحــة لتطــوير أبعـاد

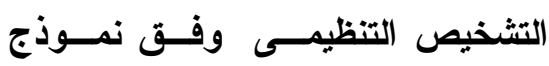

Six-Box ويسبورد للصناديق الـست

: Model

البعد الأول : الأهداف

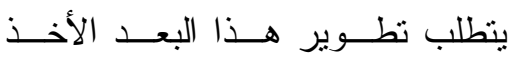

بمجموعة من الإجراءات المقترحة من أهمها

ما بلى :

ا- عقد إدارة المدرسة العديد من اللقــاءات و الحوار ات و الاجتماعات الدوريـــة مـــع ملع
ب -1 - أن النشخيص التنظيمــى الــدقيق و الموضوعى و الو اقعى متطلب أساسي

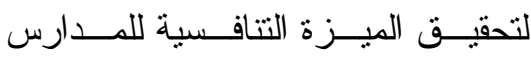
الثانوية وتفعيل دور ها في تحقيق أهداف التتمبة المستدامة.

ب-9- لكى يحقق تتظيم المدرسة الثانويــة العامة أهدافه بكفاءة ، لابد من النظـــرة المنظو مية الثاملة و المتكاملة و المتوازنة لكافة أبعاد التشخيص التتظيمــى وفــق نموذج ويسبورد ، و لا يمكن معالجة أو

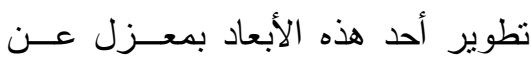
الأبعاد الأخرى ، لذلك من الــضروري الـإي أن يتسم التشخيص التتظيمى بالتكامـلـل و الثموللكافة|أبعاد المنظمة ومجالاتهـــا ومحاور ها ووحداتها الفرعية. ب-- 1- أن النتخيص التتظيمـى عمليــة دورية مستمرة ومستدامة ، نظراً لتغير الظـــروف و المتغيـــر ات و المـــــثرثز ات الخارجية و الداخلية و انعكاساتها علـى عى ولى المنظمة. ب-11 - أن التشخيص التتظيمى لا يتوقف عند مجرد تحديد وتقييم الوضع الحالى للمنظمـــة ، و إنمـــا يــستهدف إجـــر اء تغييرات وتعديلات و إصلاحات حقيقية

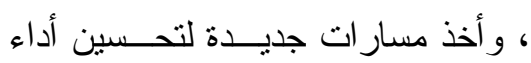
المنظمة وتحقيق أهدافها بفاعلية. 
ع - تشكيل لجنة ممنلــــة لكافــة المنتــسبين للمدرسة ، تتولى تلقى وبلورة مقترحات

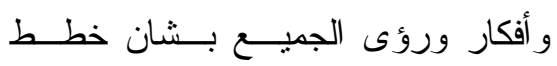
التطوير و التحسين المدرسى ، و وآليـات

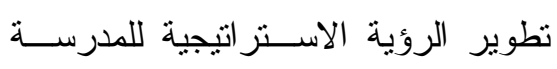

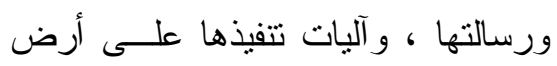

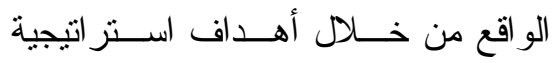

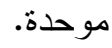
0ـ عقد العديد من اللقــاءات والاجتماعــات و الحلقات النقاشية الحوارية لوضع خطة تتفيذية لكيفية تطبيــق رؤيسـة المدرســـة

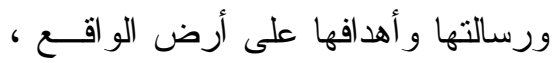
يشارك فيها ممثلون عن كافة المنتـسبين ونسين للمدرسة من هيئة إدارية وهيئة تدريسية ومشرفى النشاط و الإداريين و الأخصائيين

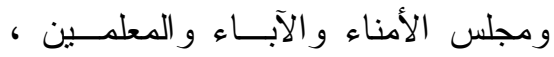
وممتلين عن المجتمع المحلى وقيــادات المجتمع ، بحيث تغطــى الخطــــة كافــة

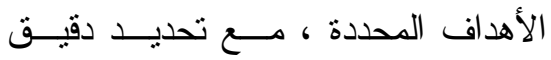
لمسـسئوليات تتفيــذ الأنــشطة و المهـــام

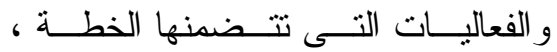
وأن يكون هنالك جدول زمنى للتنفيــذ ، مع وضع مؤشر ات للتقيــيم ، وترجمــة

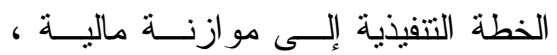

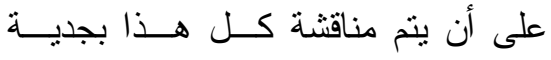
و استفاضة.
كافة المنتسبين للمدرسة للاســـماع الــى آر ائهم ومقترحاتهم و أفكار هم بشأن رؤية

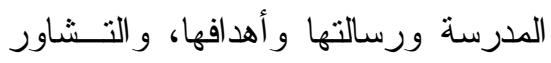

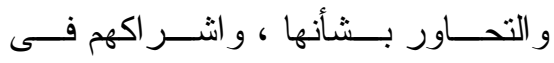

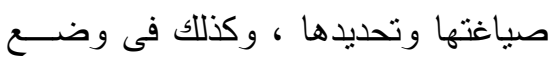

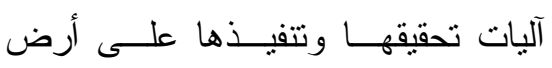
الو اقع. r- الأخذ بمجموعة من الآليـات و الوســائل

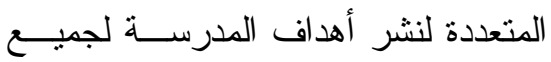

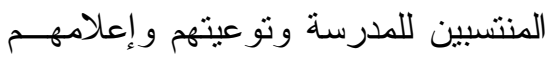

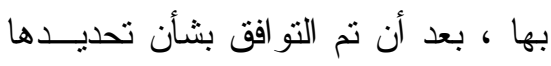
وصياغتها ، وقد يتم ذلك من خلا : • الملصقات و الكتيات. • المطبو عات و الأدلة.

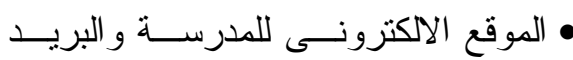
الالكترونى للمنتسبين إليها. • اللقاءات الحوارية و الحلقــات النقاثــــة و الاجتماعات الدورية. r- إجر اء مجموعة من المقـابلات وورش

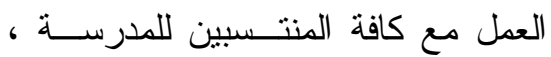

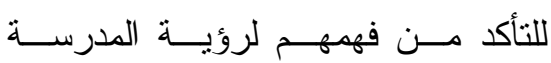

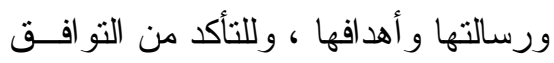

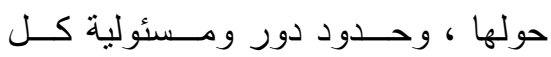

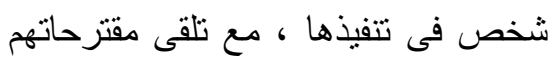
وآرائهم فى هذا الصدد ودر استها جيــــاً ووضعها فى الاعنبار الفعلى. 
• تشجيع وتــــعيم الاتــصالات الــشبكية

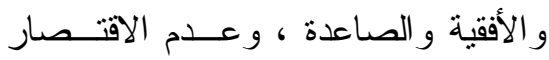
على الاتصالات الر أسية وفقط.

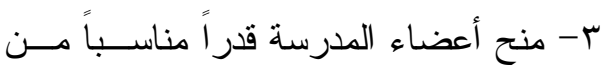

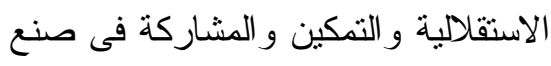
القرار و إدارة المدرسة وحل مشكلاتها. ـ - إعطاء إدارة المدرسة اهتمامــاً مناســباً

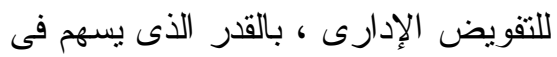
إعداد صف ثانى من الكوادر القيادية. 0- تشجيع التتظيم من خله فــرق العدـل

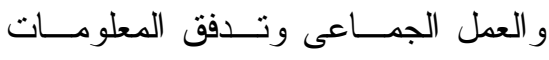
و انسيابها ، مع تدعيم الاتصالات الثبكية

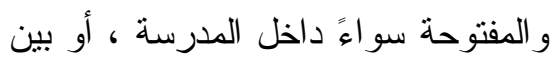
المدرسة وأولياء الأمور و البيئة المحلية. ج- وجود دليل تتظيمى أو لائحسـة تتظيميــة معتمدة وو اضحة ومعلنة تضم منظومسـة

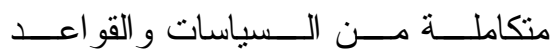
و الإجر اءات التى تحكم العمل المدرسى ، ولنى

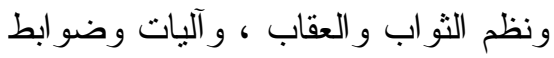
العمل داخل المدرسة فى كافة أبعاده.

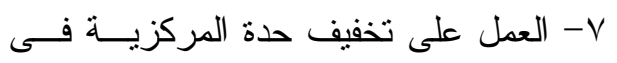

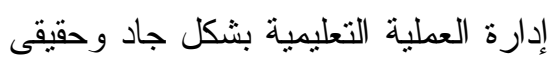

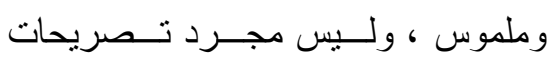

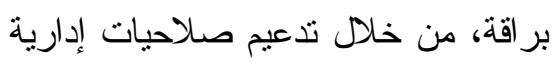

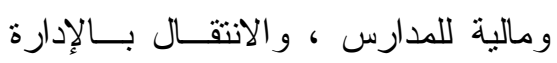

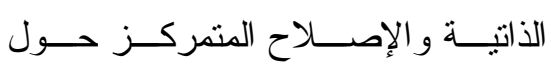

البعد الثانى : الهيكل التنظيمى

يتطلب تطوير هذا البعدالأخذ بمجموعة

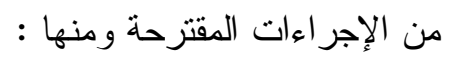

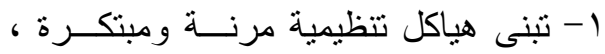

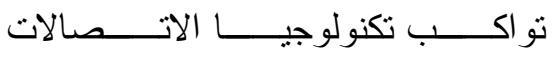

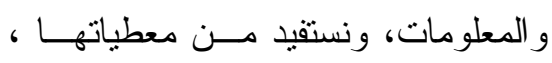

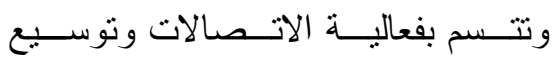
مشاركة العاملين فى صنع القرار ، وتحد

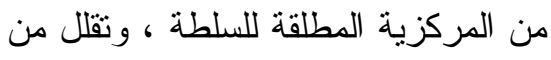

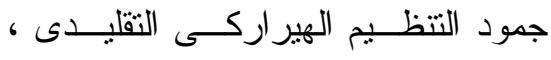
وتنتجيب لمتطلبات المستقبل ومتغيراته وتحدياته. r - دعم قنوات الاتصـال المفتوح و المباثـــر بين إدارة المدرسة و العاملين ، ويمكن أن يتم ذلك من خلال : • عقد إدارة المدرسة للقــاءات و النــدوات وورش العمل و الاجتماعــات المفتوحسـة و التى تيسر وتعزز التعاون و التفاعل بين كافة المنتسبين للمدرسة.

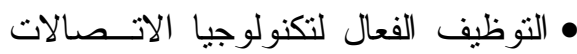

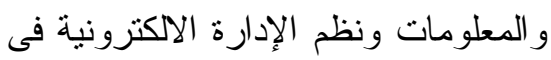
تفعيل آليات التو اصل بين إدارة المدرسة

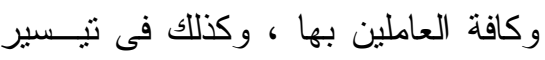

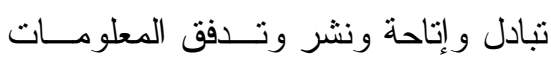
الصحيحة داخل المدرسة.

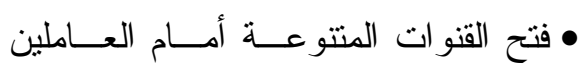
بالمدرسة لتوصيل أفكار هم ومقترحساتهم لإدارة المدرسة. 
• تدعيم فكرة اللجان الجماعية وفرق العمل الحقيقية وليس العمل الفردى.

• تدريب العاملين بالمدرسة على مهــار ات

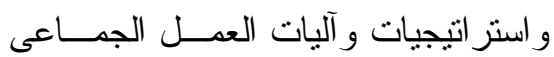

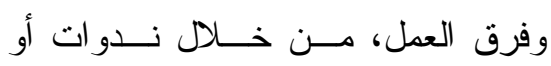

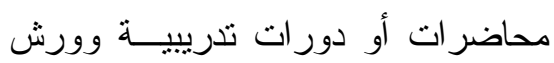
عمل ، يمكن أن ثقوم بها وحدة التدريب

$$
\text { و الجودة بالمدرسة. }
$$

r- العمل الجاد على توفير مناخ صحى من

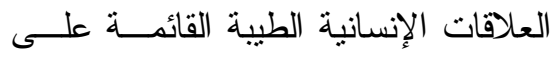

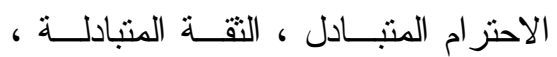
الثفافية و المصارحة ، العدالة فى توزيع

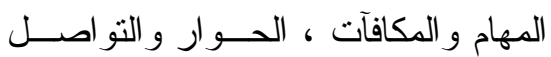
و التعاون بين الجميع. r- تنبى أنماط قيادية مناسبة للتعامل بفاعلية مع الصراع المدرسى ، فى إطار نثقافـــة

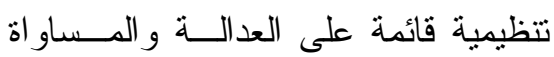
و الثفافية و الموضو عية وكثف الحقائق ،

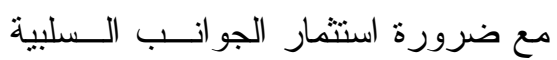

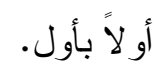

عـ ضرورة التحول مــن ثقافــة المدرســـة

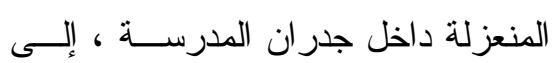

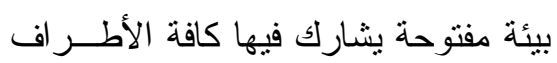

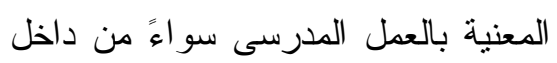

$$
\text { المدرسة أو من خارجها. }
$$

المدرسة من حيز التصريحات النظريـــة

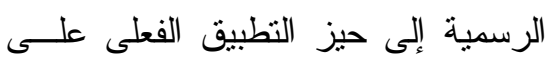

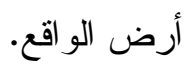
البعد الثالث : العلاقات لو الع

يتطلب تطوير هذا البعد تنبى مجموعة من الإجر اءات المقترحة منها : I- تشجيع وتدعيم العمل الجمـاعى وروح الفريق.

\section{ويمكن أن يتحةـق ذلـــــــن خــلال} ما يلى :

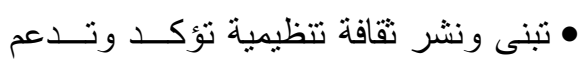

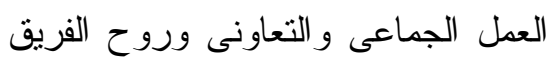

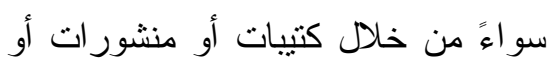
محاضرات نوعوية توضح أهمية العمل فئول

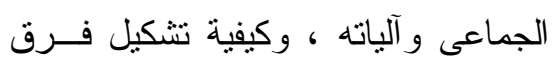
العمل وطبيعتها و استثمار ها.

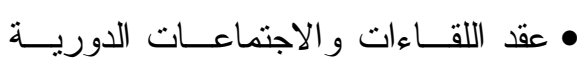
و الحلقات النقاثشية مع كافـــة المنتـسبين

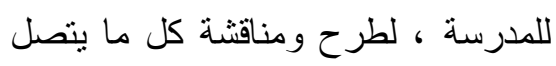
بنظام العمل فى المدرسة. • انثاء منتدى للحوار يلتقى فيه العـاملون

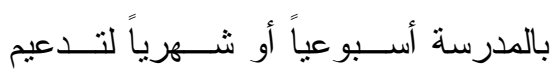
فرص التفاعل الجماعى داخل المدرسة. • تشجيع العاملين بالمدرسة علـى تقاســـ

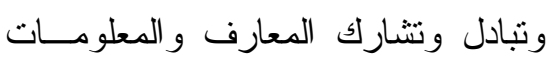
و الخبر ات الوظيفية فيما بينهم . 
1 - ربط الحوافز و المكافآت المقدمة للعاملين

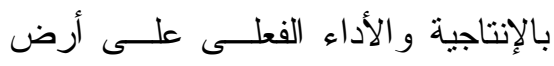
الو اقع ، ومن أمثلة ذلك :

• ربط الحـــو افز و المكافــآت بالمــشاركة الفاعلة فى اللجان و المجالس المدرسـية

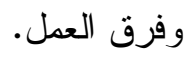

•ربط الحــو افز و المكافــآت بالمـشاركة الفاعلة فى الأنشطة المدرسية والطلابية. • ربط الحو افز و المكافآت بالالتحاق ببر امج الدر اسات العليا و البحث العلمى. • ربط الحو افز و المكافآت بحضور الندوات

$$
\text { و المؤتمر ات العلمية. }
$$

• ربط الحوافز و المكافآت بحضور دورات تدريبية وورش عمل ولقات نقاثية.

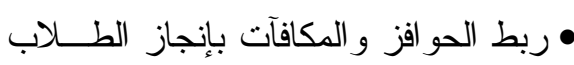
و أدائهم الحقيقى.

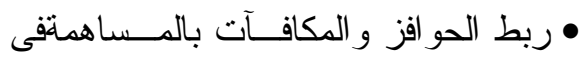

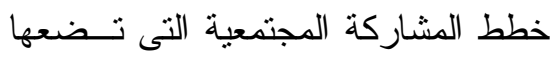

$$
\text { المدرسة. }
$$

• ربط الحو افز و المكافآت بالمشاركة الجادة فى حل مشكلات المدرسة وتطوير الأداء • ربط الحوافز و المكافآت بعدـل بحــــــ إجر ائية أو نـشـر أبحــاث فــى مجــال

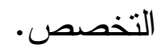

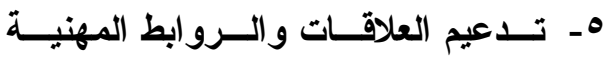
والاجتماعية والإسـسانية بـين كافــة ولئة المنتسبين للمدرسة . الاجئمياعه والإن. ويمكن أن يتم ذلك من خلال :

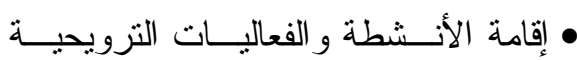

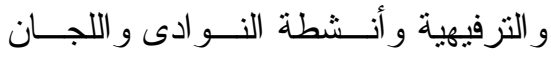
الاجتماعية و الاحتفــالات و المهرجانــات

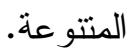
• عقد العديد من اللقاءات الجماعية غيـر الرسمية لتبادل وجهات النظر و التحــاور

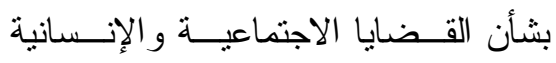
و الثخصية.

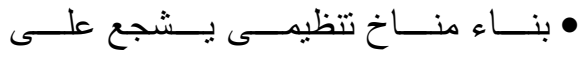

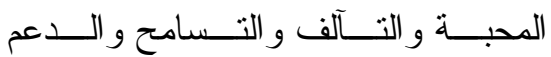

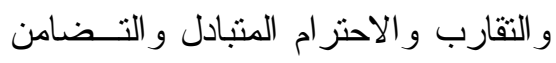

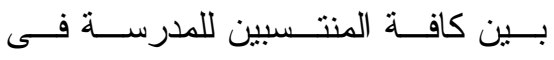

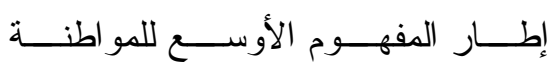
التتظيمية. • مر اعاة الجوانب الثخــصية و الإنـسانية

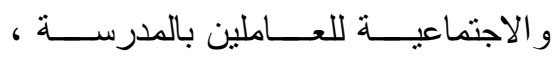
ومــــاركتهم مناســــاتهم الاجتماعيــــة وقضاياهم الثخصية و الأسرية. البعد الرابع : المكافآت والحوافز :

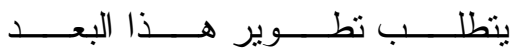
الأخذ بمجموعة من الإجراءات المقترحة من

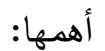


وحل مشكلاتها عن الذى ليس لديه ولاء و انتماء حقيقى لمدرسته هئه

ـ- أن يكون هناك تكريم سنوى أو جـائزة سنوية تثمل : • تكريم الحاصلين على جو ائز كبرى سواءً

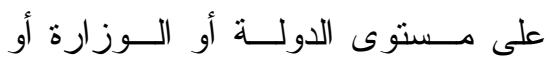
المديرية. • تكريم الذين تم تــــيتهم إلــى درجــات وظيفية أعلى خلال العام. • الحاصلين على الماجستير و الدكتور اه أو بر امج الدر اسات العليا.

• من قــدموا أو نــشروا أبحاثــاً علميـــة بالمؤتمر ات القومية و المحلية.

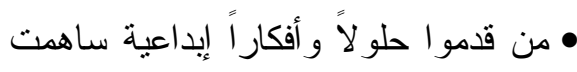
فى تطوير المدرسة أو التخصص. • من ساهمو ا بشكل فعال فى إثز اء وتفعيل الأنشطة الطلابية.

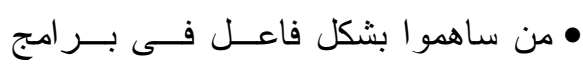

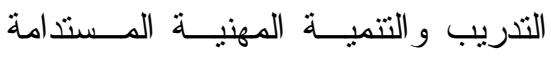
للعاملين داخل المدرسة. البعد الخامس : القيادة يتطلب تطوير هذا البعد الأخذ بمجموعة

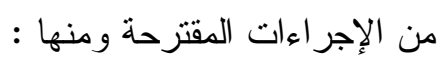
1- تبنى القيادة المدرسية ثقافة تتظيمية تثجع على مشاركة العاملين فى صنع القــرار

$$
\text { و إدارة المدرسة. }
$$

• ربط الحوافز و المكافآت بالكفـــاءة فــى إدارة إحدى الوحدات الفرعية بالمدرسة.

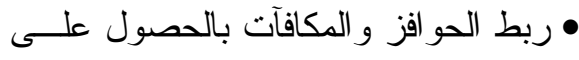

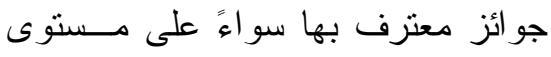
الإدارة التعليمية أو المديرية أو الــــوزارة أو على مستوى الدولة. • ربط الحو افز و المكافآتبدرجة الاتــضباط و الالتز ام الأخلاقى و السلوكى و التزبوى. • ربط الحو افز و المكافآت بمدى التطور فى الأداء المهنى بكافة أبعاده.

r- أن تستتد الحو افز و المكافآت إلى سياســـة و اضحة ومعايير علمية موضوعية متفق لئن

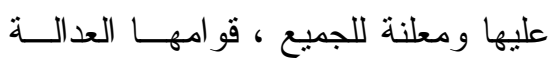
و الثفافية و الموضوعية.

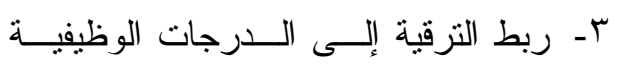
الأعلى بالمعايير و الأبعاد التى تم الإثشارة

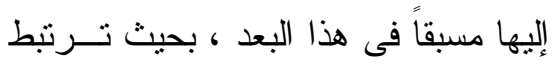

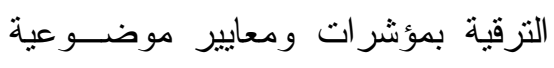
مقننة وو اضحة ومتتوعة ، وليس مجرد انقضاء عدد معين من السنوات فى آخر وله ولهن وظيفة. ـ ـ التوقف عن إعطاء المكافآت و الحـــو افز

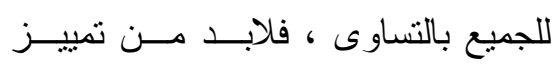

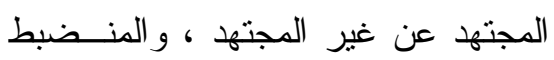
عن غير المنــبط، و الإيجـابى عـن فئن السلبى ، و المشارك فى نطوير المدرسة 
• إدارة المدرسة لمدة يوم أو عدة أيام. • حضور إحــدى الاجتماعـات بــالإدارة التعليمية أو المديرية.

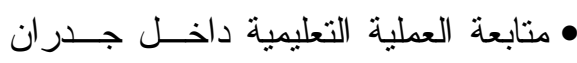
المدرسة وفصو لها لمدة معينة.

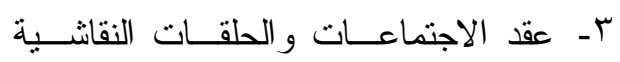
الدورية مع العاملين بالمدرسة لتــدارس

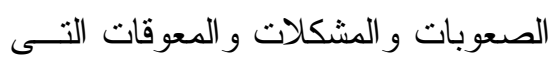
تعوق العمل ، و اقتز اح الآليات و الأساليب الملائمة للتغلب عليها. ع- تهيئة القيادة المدرسية لمنــاخ مدرسـى

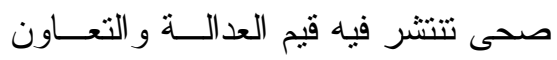
و الثنفافية و الثقة و الحــوار و المــشاركة

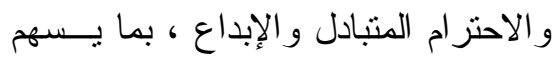
فى تعزيز بيئة مدرسية جاذبة وصــالحة ولادية للتعلم الفعال.

0ـ ـ دعم بر امج التدريب و التتميــة المهنيــة

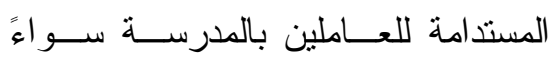

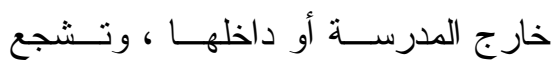

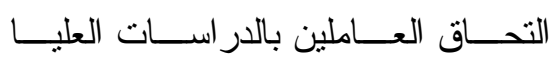

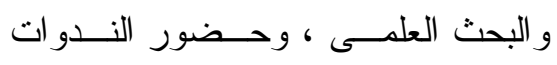

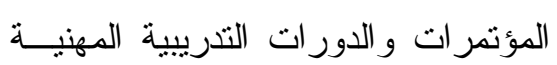
المتخصصة. T- تشجيع القيادة المدرسية للعـاملين عـى الألى الإبداع و الابتكار و التجديد و المبادأة.
ويمكن أن يتحقق ذلك من خلال ما يلى :

• عقد اللقاءات و الاجتماعــات و الحلقــات النقاشية للنشاور بشأن المشكلة أو القضية المزمع اتخاذ قرار بشأنها. • تنبنى القيادة المدرسية للأنمــاط القباديـــة الحديثة و التى تعتمد على إتاحة الفرصــة

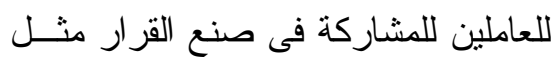

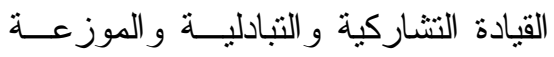

$$
\text { و غير ها. }
$$
• اقناعالعاملين بأهمية دور هم فى المشاركة فى إدارة المدرسة وصنع القرار .

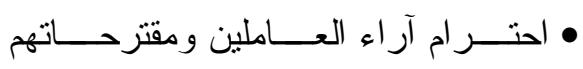

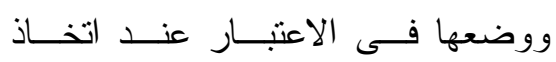
القر ار ات. • إقامة ندوات ومحاضر ات للتوعية ونشر ثقافة المشاركة بين المنتسبين للمدرسة.

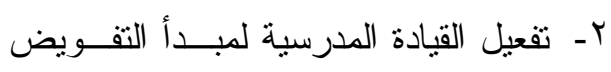

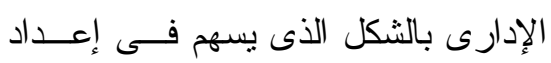

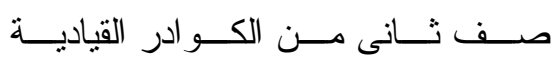
المستقبلية، ويمكن أن يتم التفويض فـى أنى أمور عديدة منها :

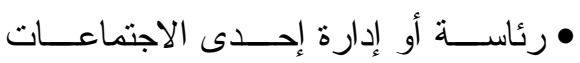
المدرسية أو جلسات مجلس الإدارة. • وضع خطة للإشر اف اليومى و الأسبو عى الخى داخل المرسة. • إعداد الخطة التدريبية للعاملين بالمدرسة. 
أو الإدارة التعليمية وكذللك من الجامعسـة وقيادات المجتمع المحلى للاحتفاء وتكريم العاملين المبدعين و أصــــاب الأفكـار

$$
\text { و الحلول الإبداعية. }
$$

البعد السادس : الآليات المساعدة : ينطلب تطوير هذا البعد تبنى مجموعة

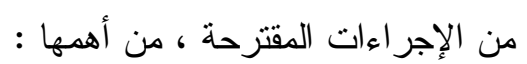

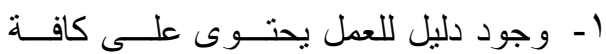
السياسات و القو اعد و الأنظمة و التعليمات

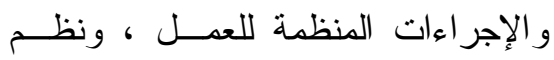

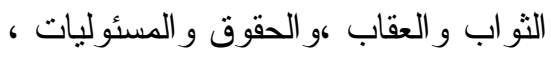
على أن يكون هذا الدليل متاحاً ومعلنـاً للجميع. r- عقد اجتماعات ولقاءات حوارية دوريـــة

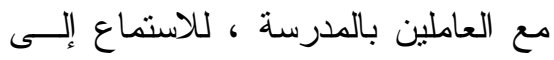

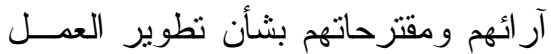

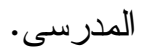

r- توظيف التكنولوجيا و التقنيات الحديثة فى

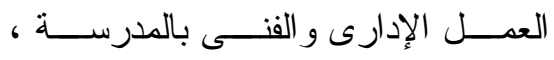
وتطبيق منظومة الكترونيــة معاصــرة

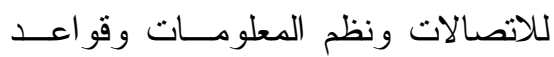

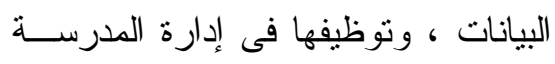
ودعم اتخاذ القرار ، وكذللك نوظيفها فى

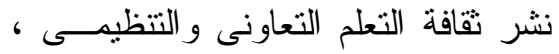

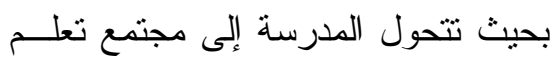
مهنى فعال. ع - دعم الإدارة المدرسية لفــرص التتميــة المهنية المستدامة للعاملين بالمدرسة.
ويمكن أن يتحقى ذلك من خلال :

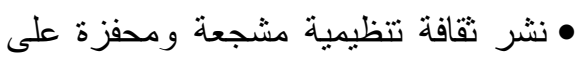

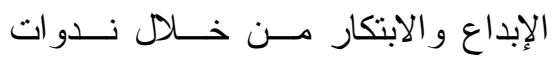
و ملصقات وورش عمل وغير ها. • تهيئة بيئة العمل المدرسية لتقبـلـل فكــرة النظوير و التحسين المسـتصر و التغييــر الهادف. • اتباع القيادة المدرسية للأنماط و الأساليب

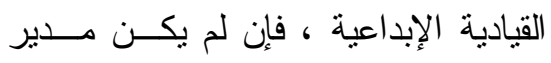

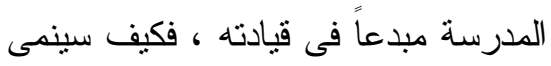
الإبداع فى المرؤوسين.

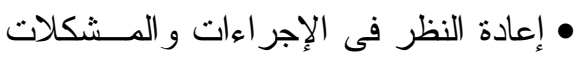
الإدارية و التنظيمية التى قد تعوق التجديد

$$
\text { و الإبداع. }
$$

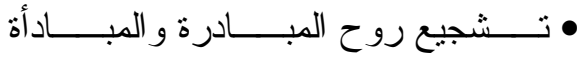
و المخاطرة المحسوبة. • ترك مساحة مــن التغييــر و الإصـــلاح و النطوير نأنى من أسفل.

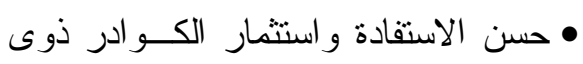
العقليات الإدارية و التتظيمية المبدعة.

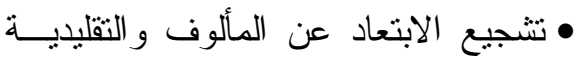
و النمطية فى الأداء. • •قديم الدعم المادى المعنــوى المناســبـ

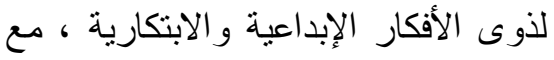
تخصيص مكافآت وحو افز مادية وأدبيــة ومعنوية لهم. • الدعوة لاحتفال سنوى ينم فيه دعوة كبار

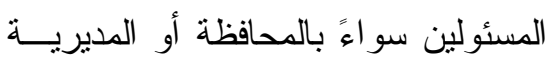


0ـ تفعيل استخدام أساليب الاتصال المتبادلة مثل نظم الاقتز احات ، لوحة الإعلانــات

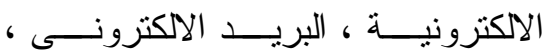
الاجتماعات المفتوحة و اللقاءات الحوارية الفعالة ، و الحلقات النقاشية الهادفة. 7- توفير بيئة مدرسية جاذبة ومشجعة على

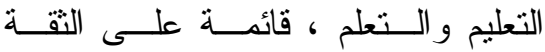

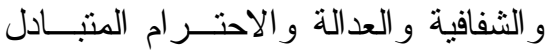
و المشاركة ، و استحداث بنــى و هياكـلـل وتكوينات مدرسية أكثر مرونة وجاذبيــة مثل قاعات وحجرات الأنشطة المفتوحة و الوحدات الإدارية المتكاملة و الحجرات المدرسية المتحركة والمختبر ات الآمنــة و الملاعب الخضر اء ، بما بـسـهم فـى تحقيق مفهوم أو نمط المدرسة الجاذبة. د-متطلبات نجــاح الإجــراعات المقترحــة وضمانات تتفيذها بكفاءة :

أ-متطلبـــات مرتبطـــة بعمليـــة التـشخيص التنظيمى نفسها : ا - أن ترثبط أية مبادر ات للتغيير و التطوير بالنتائج الحقيقية للتشخيص التتظيمى. r - أن يتشم النشخيص التتظيمــى بالــشمول و التوازن و التكامل لكافة أبعاد المنظمـــة

$$
\text { ووحداتها الفرعية. }
$$

r- أن يتسم التشخيص بالدقة و المــصـارحة

$$
\text { و الثفافية و الو اقعية و الموضو عية. }
$$

ويمكن أن يتم ذلك من خلال ما يلى :

• نشر وتبنى ثقافة تتظيمية داعمة للــتعلم

المستمر و التتظيمــى و التتميـــة المـنيـــة

المستدامة ، بحيث تصبح جزءً من ثقافة المدرسة.

• وضـع برنامج لتحفيـز العـــاملين علــى

الانخر اط فيى أنــشطة التنميــة المهنيــة

المستدامة وحضور الندو ات و المؤتمر ات

العلمية المتخصصة.

• تحفيز وتشجيع العاملين علــى الالتحـــاق

بير امج الدراسات العليا و البحث العلمى

وعدم وضـع العر اقيل و العقبات أمــامهم فى هذا الثنأن.

• نشجيع العاملين علــى إجــر اء بحــوث

إجرائية أو بحوث الفعل ، للإسهام فـي حل مشكلات المدرسة سواءً الإدارية أو الفنية.

• انشاء جماعات تعلــم أكاديميــة علــى

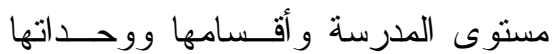
الفرعية ، بما يثجع علاقِــات الزمالـــة و التعاون و التكامــلـل وتبـــادل المعرفـــة و ونشار كها. • دعم ونتجيع العــاملين علــى حــضور البرامج التدريبية المتخصصة فى توظيف التكنولوجيــــا و التقنيـــات الحديثـــة فـــى العمليات الإدارية و الفنية بالمدرسة. 
r ا أن يكون هناك تدريب فعال للقائمين على أمر التشخيص فى كيفية استخدام وتطبيق

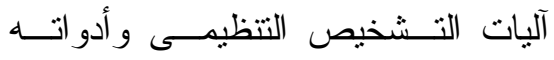
ونماذجه و أساليبه بصورة فعالة.

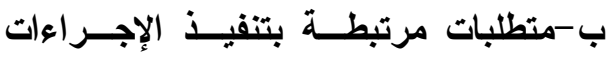
المقترحة :

لكى تحقــق الإجـــر اءات المقترحسـة

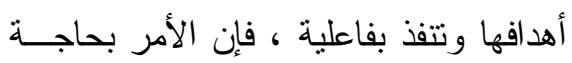
إلى مجموعة من المتطلبات و الــضمانات الأساسية ، منها :

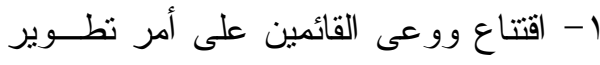

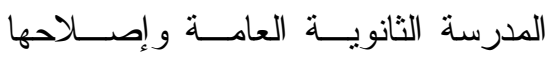
بالعلاقة الوطيدة و الصلة الوثثيــة بـين

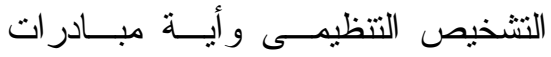

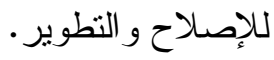
ץ- قناعة القائمين على أمر التعليم فى مصر

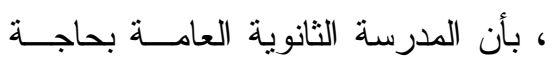
ماسة إلى تتخيص تتظيمى دقيق لو اقعها

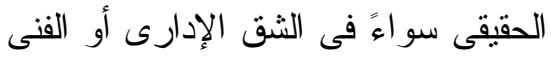

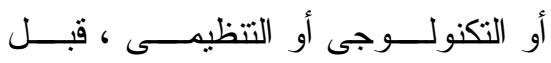

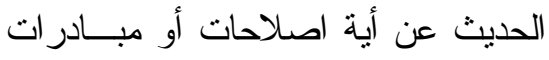

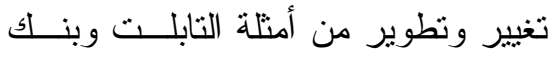
المعرفة وتغيير نظم التقييم و الامتحانـات من ونسات و غير ها. ب- توفير المو ارد المالية و المادية اللازمسـة

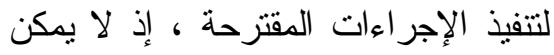

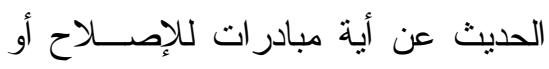

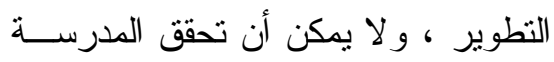

ع- ضرورة أن ينم التشخيص بصفة دورية

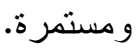
0ـ ــو افر المهار ات و القــدرات و الكفايــات

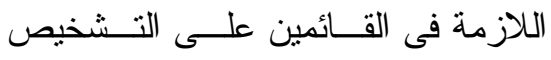

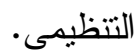
7- تيسير سبل الحصول علــى المعلومــات الحقيقية للقائمين على التشخيص.

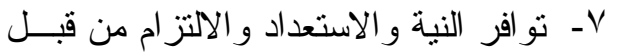

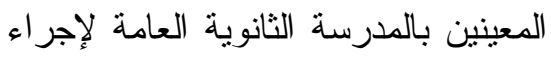

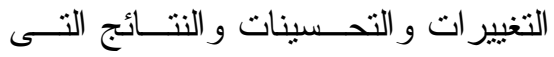
يخرج بها التتخيص التتظيمى. 1- قناعة و اقتتاع القيادات التعليمية و الإدارية

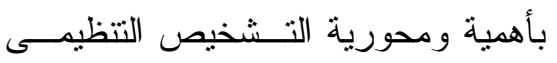
ودوره الرئيس فى كافة عمليات التغييــر و والتطوير - ودور الرن

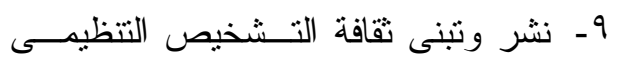
وأهميته المحورية بالنسبة لأية مبادرات

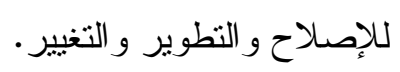

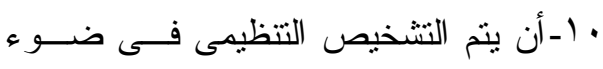

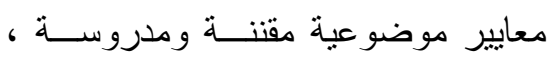
للحكم على أبعاد التـشخيص أو أبعـاد الأداء التتظيمى بشكل جيد.

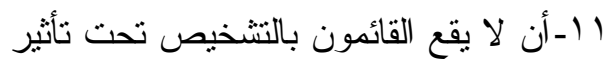

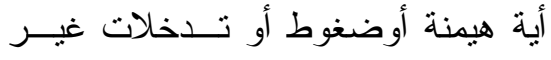
علمية ، حتى يكون التشخيص موضوعياً

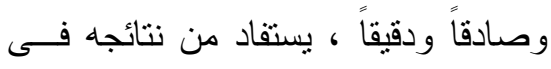

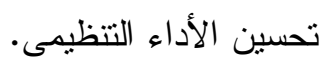


- احداث تغيير ات فــى البيئــة المدرســية

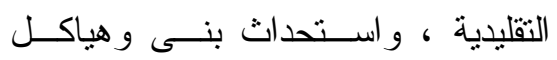
مدرسية أكثر مرونة وجاذبية ، بحيــث

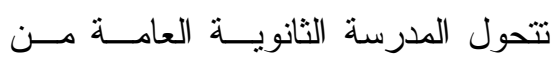

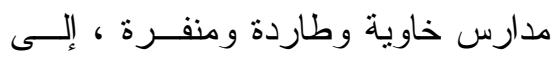
مدارس مشجعة وجاذبة لطلابهــا ، و وإلا ونال

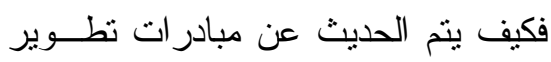
و إصلاح فى مدارس خاوية من بضاعنها الأساسية و هم الطلاب.

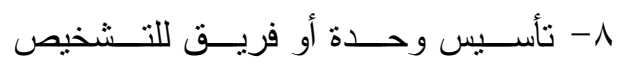

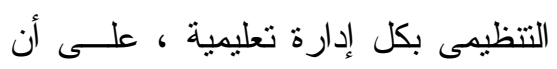

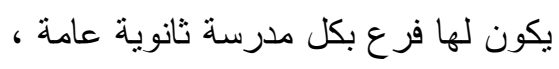

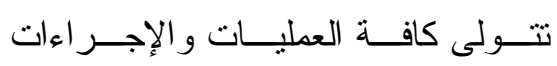

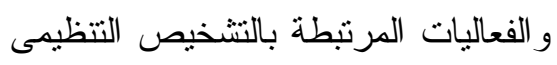
الدورى والمستمر لكل الددارس الثانوية العامة ، تضم الوحدة ممنلين عن كافــة

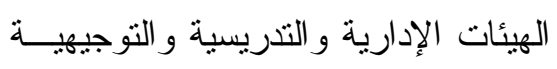

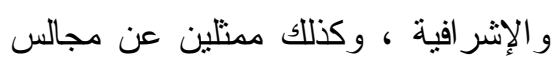

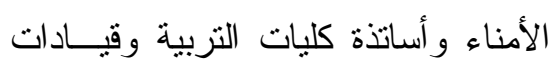

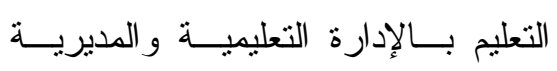

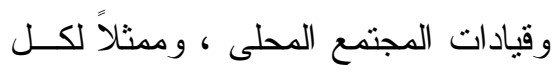

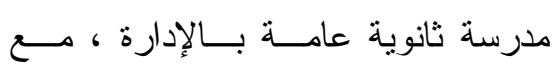

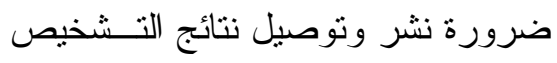
التنظيمى لكافة الجهات المعنيــة ســـــــاءً

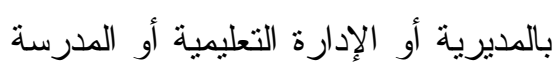

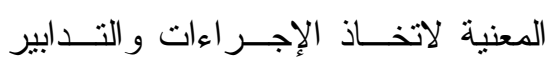

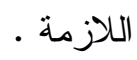

الثانوية رؤيتها ورسالتها و أهـــدافها دون مو ارد مالية ومادية وبشرية مناسبة ، بل رون ونية دون وضع الإنفاق على التعلــيم عامــة

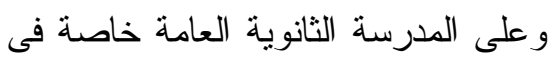
أولويات انفاق الدولة المصرية. ع - تبنى المدخل المنظومى عند نتاول قضايا

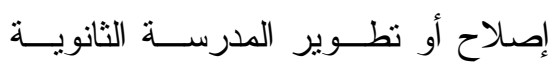
العامة ، بحيث ينم التعامل مع كافة أبعاد

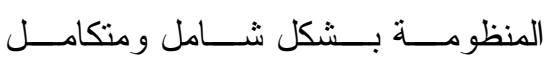
ومتو ازن. ه- التخفيف الجدى - وليس مجرد شعار ات وتصريحات منمقة - من حدة المركزية

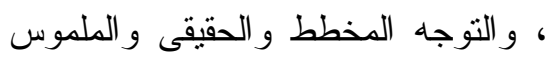

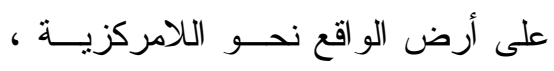

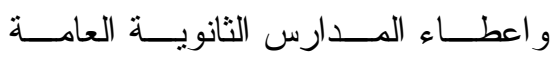
استقلالية وصلاحيات أوسع فــى إطــار مفـــاهيم الإدارة الذاتيــــة و المـــشـاركة

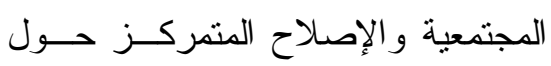

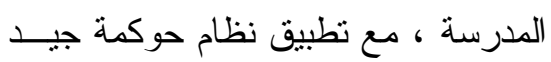
بالمدارس الثانوية العامة. 7- تو افر إر ادة سياســية ومجتمعيــة قويـــة وجادة وثابتة ، مع استعداد و التزام حقيقى لئي

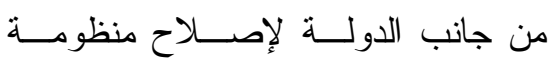
المدرسة الثانوية العامة ، وليس مجــرد لإندان تصريحات منمقــة وشــعار ات بر اقـــة ومبادر ات فوقية لا نرتبط بو اقع المدرسة ونة الثانوية العامة. 
Practice : A Cross Classification Analysis Using the DEL - Technique, University of Groningen, the Netherlands, 23 March, 1998, p. 3.

5. Vida Korkor Tetteh : Organizational Diagnosis - A Management Tool for Children in the Telecommunication School of Business, KNUST, College of Art and Social Sciences, August 2012, p. 23.

6. Deborah A.O'Neil : op.cit., p. 52.

7. Coleman C.A. : op.cit., p. 3, p. 7.

8. Virgil - Ion Pqpovici : op.cit., p. 151.

9. Jingxiao Zhang et al. : An Integrated Diagnostic Framework to Manage Organization Sustainable Growth : An Empirical Case, Sustainability, 8, 301, 2016.

Available at :

www.mdpi.com/2071$1050 / 8 / 4 / 301 / \mathrm{pdf}$ in $15 / 10 / 2018$.

10. Zoya V. Yakimova, et al : "Organizational and Corporate Culture : Diagnostics Methods", Journal of Scientific Research and Development, Vol. 3, No. 6, 2016, p. 45.

$$
\text { (1) }
$$

- فوارية بلبـشير : نمـاذج التشـيص

التظظيمى ودور ها فى إعداد اســنز اتيجية

\section{المراجع}

1. Coleman, C.A.: "Organizational Diagnosis in the Logistics Sector in Ghana: an Application of the Barke-Litwin Model", Journal of Entreprenurship \& organization Management, Review Article, Vol. 7, Issue 2, 2018, p. 7.

2. Sea :

- Bilal Bin Saeed \& Wenbin Wang : "Sustainability Embedded Organizational Diagnostic Model", Modern economy, Vol. 5, 2014, p. 425.

- Virgil-Ion Pqpovici : Organization - Organizational Diagnosis - Organizational Performance - Issential Elements in Development of A Nation, Advances in Fiscal, Political and Law Science, ISBN : 987-1-61804-191-3, Romania, n.d, pp. 151-152.

3. Deborah A.O'Neil : The Importance of Organizational Diagnosis, Journal of the Organization Development Network, OD Practitioner Special Supplement, July 2016, p. 51 .

Available at : http://www.researchgate.net/pu blication/25.9904 in 17/11/2018.

4. Thew J.B.M., Postma \& Robert, A.W. Kok : Organizational Diagnosis in 


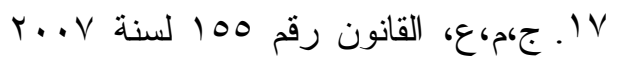

الصادر بتعديل بعــ أحكــام قـانون

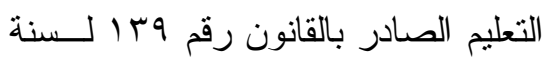

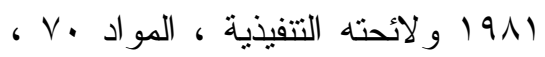

.19 ، 17 ، 10 ، 1 ـ

1 ا. جكم،ع ، رئاســـة الجمهوريـــة ، قــرار

رئيس الجمهورية بالقانون رقم به لسنة رئة

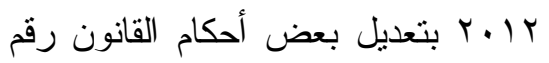

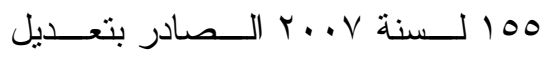

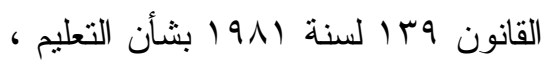

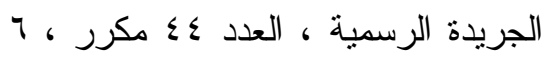

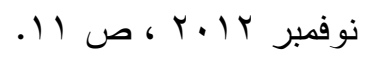

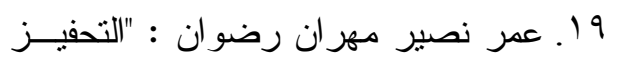

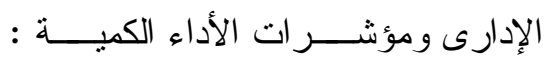

مدخل لتطوير الأداء المهنــى لمعلىــى

مدارس التعليم الأساسى في جمهوريــة

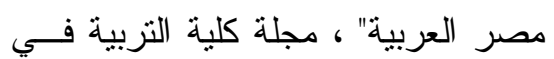

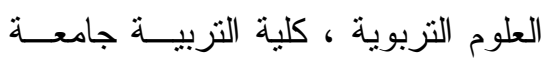

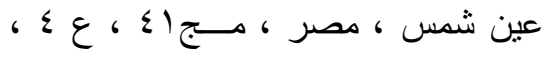

.111-1.1

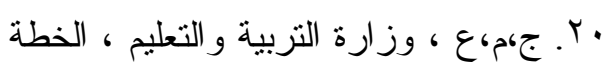

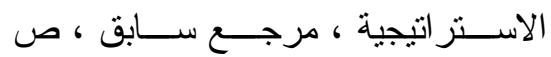

$$
\text { .1... }
$$$$
\text { : إجع }
$$

- جهم،ع ، وزارة التزبية و التعلــيم ،

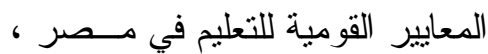

المؤسسة ، در اســـة حالـــة بالمؤســسة

الوطنية لتسويق وتوزيع المواد البترولية

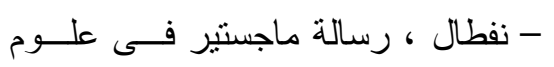

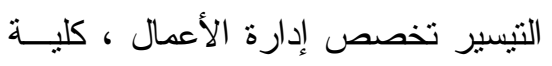

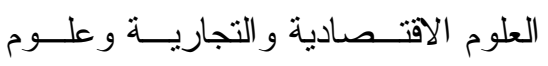

التسيير ، جامعة آكلى محند أولحسـاج -

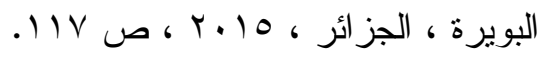

12. Josef Kasik : Organizational Diagnositc Models, Faculty of Economics, VSB - Technical University of Otrava, 2011, p. 2 available at : http://files.Jkasikwebnode-cz/200000016737ac7474a/DiagnosticModels-Briefx-pdf in 11/9/2018.

سا. فوارية بلبشير ، مرجـع سـابق ، ص .1 To

14. Jingxiao Zhang et al. : op.cit., pp. $2-4$.

10. جكم،ع ، وزارة التزبية والتعليم : الخطة

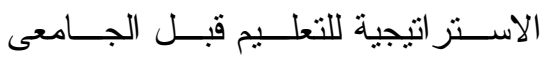

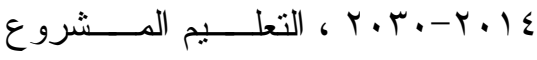

القومى لمصر - معاً نستطيع ، القاهرة

.91 ، 91 ، 9 .

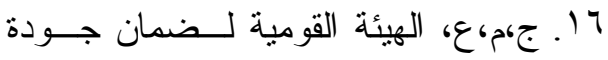

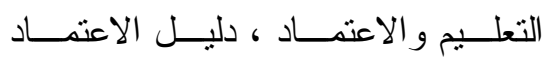

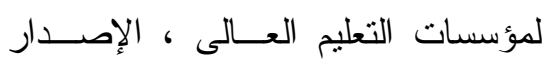

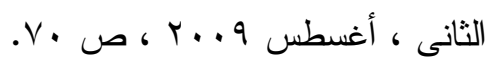


الذاتى لإدارة المدرسة الثانوية العامة في

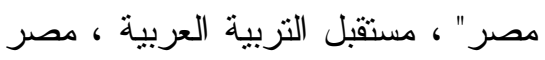

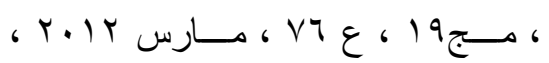

ص .1.

Tب. أحمد نجم الدين أحمد عيداروس : "التعلم

التنظيمى مدخل لتحسين كفايات الــذاكرة

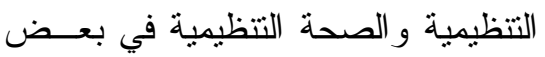

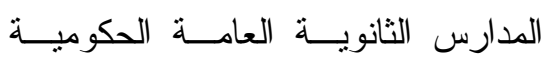

و الخاصة بمحافظ الثرقية" ، التربيــة ،

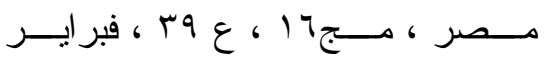
(r

rV و وائــل محمــود القطـــان : "إدارة الأداء

بالمدرسة الثانوية العامة في جمهوريسـة

مصر العربية : دراسة تحليلية"، مجلـــة فيلة

كلية التربية في العلوم التربوية ، كليـــة

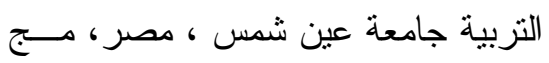

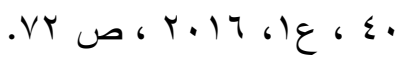

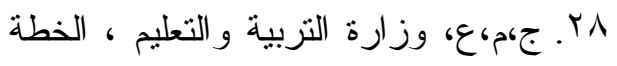

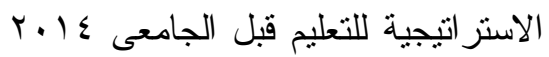

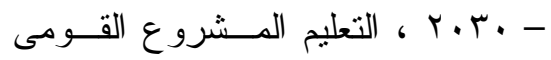

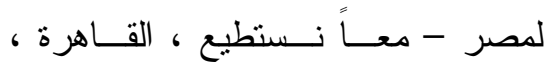

$$
\text { ( ) }
$$

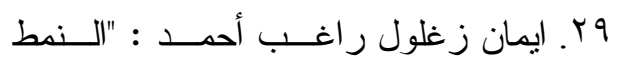

القيادى مدخل لتحويل المدارس المصرية

إلى مجتمعات تعلم مهنية : سيناريوهات

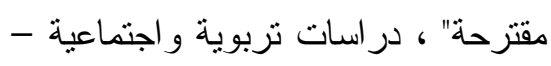

وثثيقة معايير المدرســة الفعالـــة ،

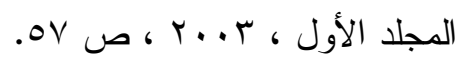

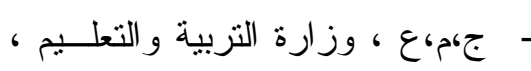

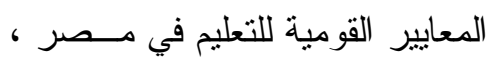

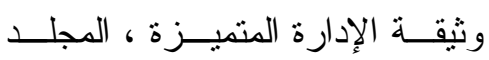

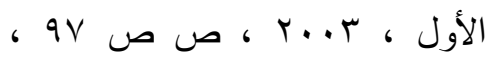
(1)

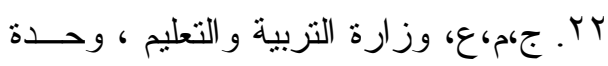

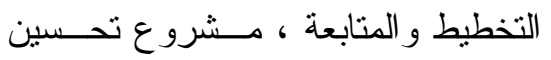

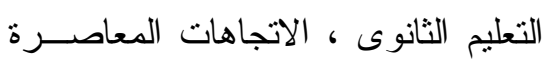

في إدارة المدرسة الثانوية ، القــاهرة ،

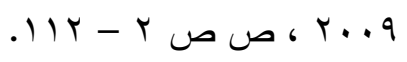

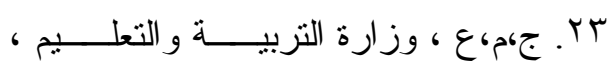

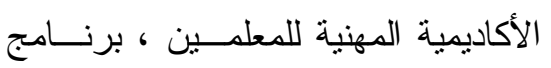

دعم التعليم - مهار ات القيادة لمـديرى

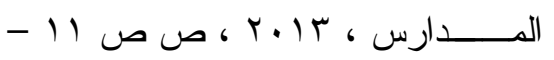

گץ. جكم،ع، وزارة التزبية و التعليم ، الإدارة

المركزيـــة لمركــز إعـــداد القيــادات

المركزية ، الإدارة العامة للتمية المهنية

، إدارة بــر امج القبـــادات ، اســـتمارة

تخطيط برنامج تـدريبى محلـى لعـام

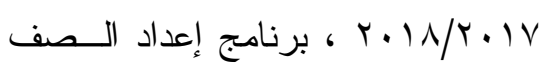

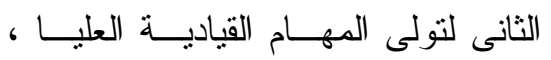

$$
\text { r. Y 11 }
$$

هr. صلاح الــدين عبــد العزيـز غنـيم :

"استر اتيجية مقترحة لتحقيق الاسـتقلاحل 
- ايمان زغلول راغب أحمد ، مرجع

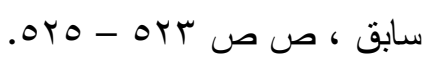

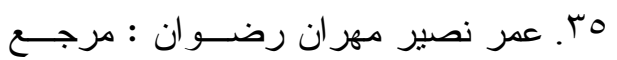

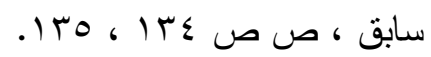

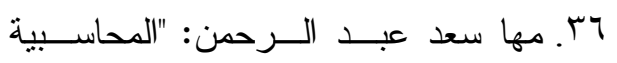

التعليمية مدخل لضمان جودة عمليـات

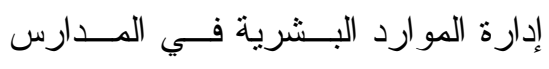

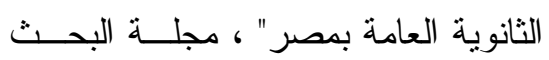

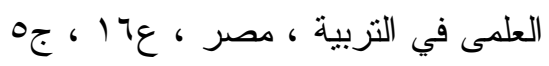

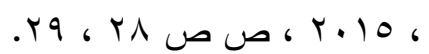

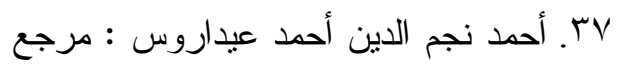

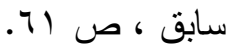

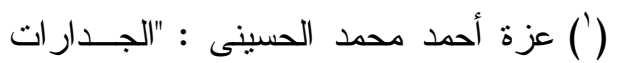

القيادية وتحسين الأداء المدرسى فــي

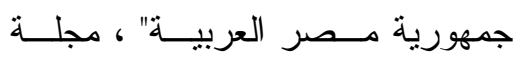

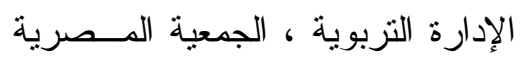

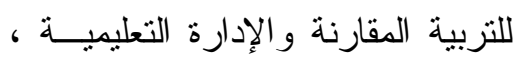

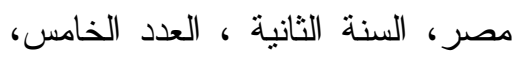

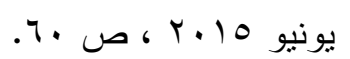

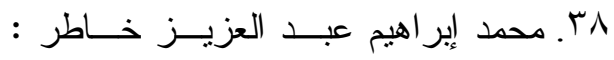

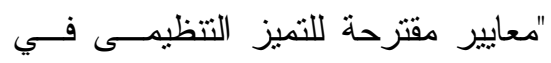

مؤسسات التعليم قبل الجامعى في مصر ملئر

على ضو ء بعـض النمــاذج العالميــة

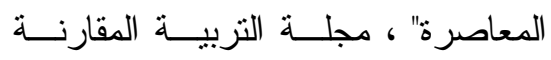

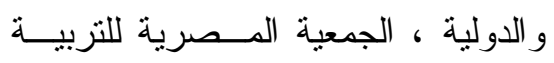

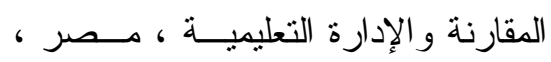

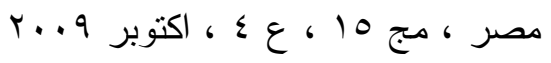

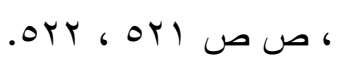

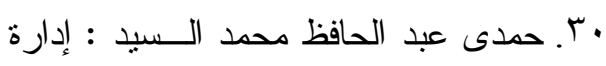

التغيير للسياسة التعليمية بمصر لمو اكبة

التطور ات العالمية بعد ثورة هب يناير :

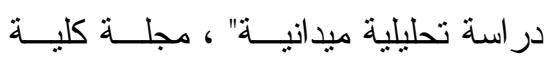

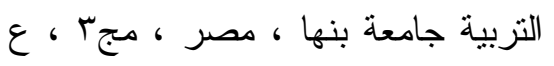

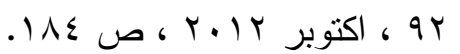

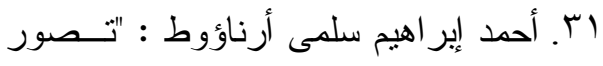

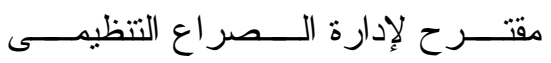

بالمدرس الثانوية العامة بمحافظة شمال

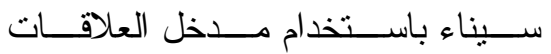

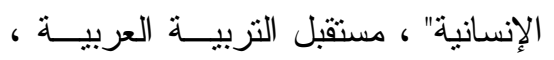

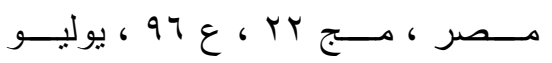

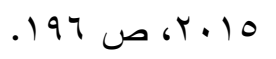

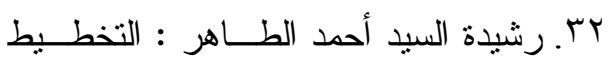

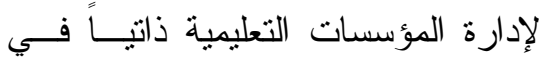

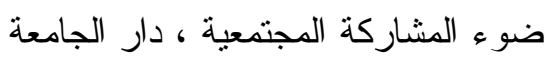

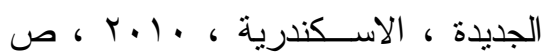

. TV

rr. أسماء محمد أحمــد عثمــان : القيــادة

التحويلية كمدخل لتحسين انجاز الطلاب

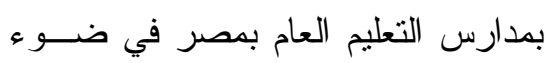

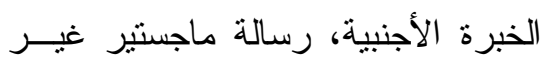

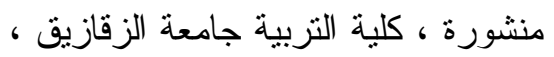

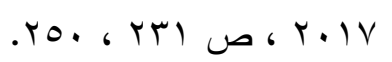


- ندى القصبى : ه أسباب تخبرك أن

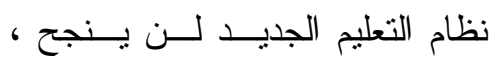

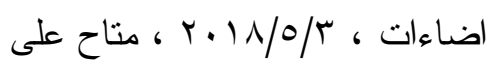

:

http://www.ida2at.com/fivereasons-

to-tell-you-that-new-educaiton in 16/11/2018.

- محمد متولى : لهذه الأســباب لــن

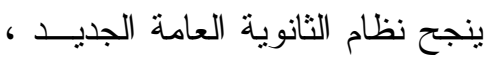

أخبار مصر ، مصر العربية ، متاح

$$
\text { على : }
$$

www.masralarabia.com/1463530 in 16/11/2018.

7ـ · ج،م،ع ، الجهاز المركزى للتعبئة العامة

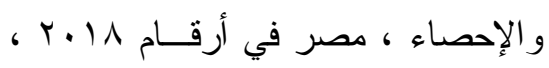

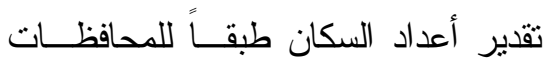

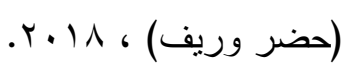

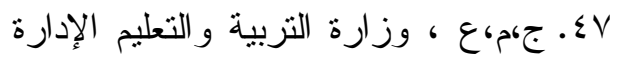

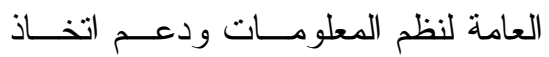

القرار ، كتاب الإحصاء السنوى للعـام

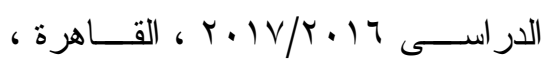

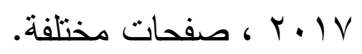

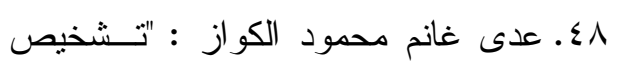

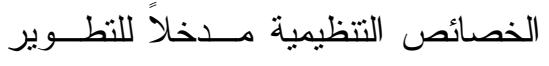
التنظيمى فــى الإتحـــادات الرياضـــية الفرعية في محافظة نينــوى" ، مجلـــة

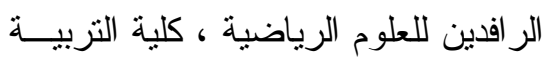

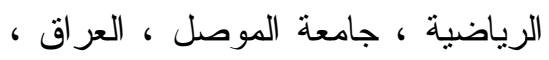

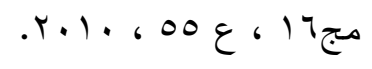

السنة الثانية ، العدد الر ابــع ، فبر ايــر .01V، 017 ص ص ص r.17

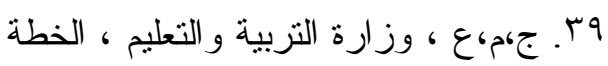

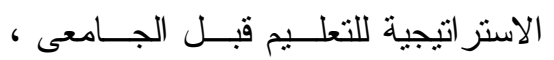

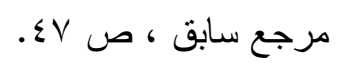

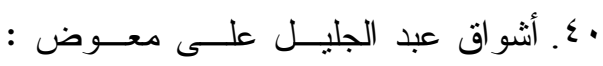

"تحسين جودة المدارس الثانوية العامــة فئس

في مصر : المنطلبات - المـشكلات -

المقترحات" ، مجلة كلية التربية جامعسـة

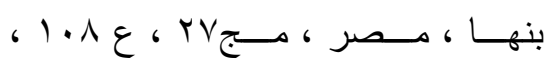

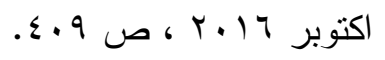

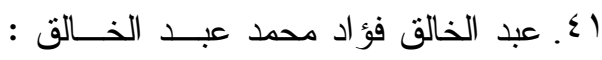

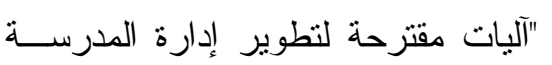

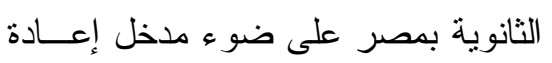

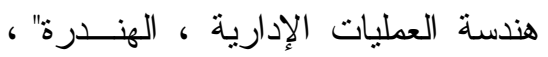

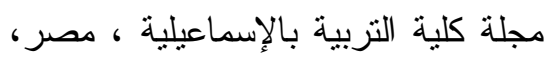

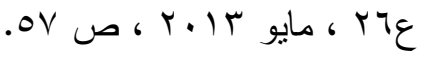

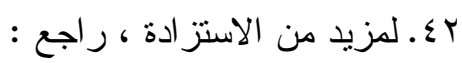

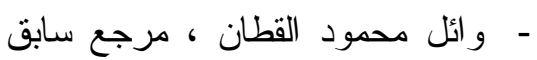

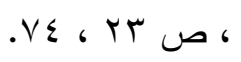

$$
\text { r }
$$

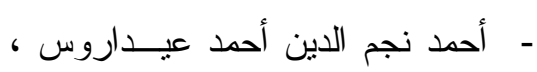

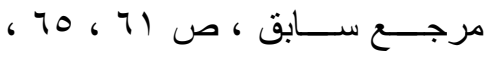

.19

§ ـ. أسماء محمد أحمد عثمان ، مرجع سابق

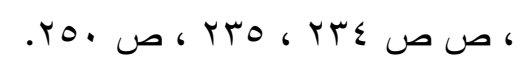

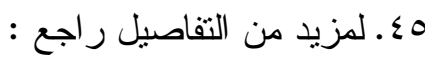


Model in Universities", Higher Education Studies, Vol. 1, No. 1, June 2011.

55. Vida Korkor Tetteh : Op.cit., 2012.

56. James M. Mcfillen et al : Organizational Diagnosis : An Evidence d- based Approach", Journal of Change Management, Vol. 13, No. 2, 2013.

57. Bilal Bin Saeed \& Wenbin Wang : op.cit., 2014.

58. Jingxiao zhang et al. : op.cit., 2016.

59. Coleman C.A. : op.cit., 2018.

$$
\text { . }
$$

- فو ارية بلبشير ، مرجع سـابق ، ص

61. Slawomir Luscinski \& Waclaw Gierulski; Diagnose of the Organization Development Research Results, p. 160.

Available at www.ptzp.org.pt/riles/konfer encje/kzz/artyk-pdf.

62. Jingxiao Zhang et al : op.cit., p. 3.

63. Virgil-Ion Popovici : op.cit., pp. 151, 152.

64. Sea :

- Van Tonder, C. \& Roodt, G., Organization

Development : Theory and Practice, Van Schaik, Pertoria, 2008.

- Bilal Bin Saeed \& Wenbin Wang, op.cit., p. 425.
9؛ سناء خضر يوسف : تـشخيص نمـط

الهيكل التتظيمى في المؤسسات التعليمية

العر اقية : در اسة حالة في جامعة صلاح

الدين - أربيل ، العراق ، مجلة تتميــة

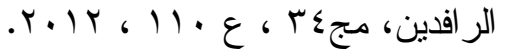

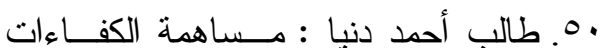

البشرية في التشخيص الاستر اتيجى فـي

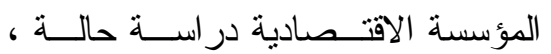

رسالة ماجسنير ، كلية العلوم الاقتصادية

و التجارية وعلوم التيسير ، جامعة محمد

خيضر ، بسكرة ، الجزائر ، ع (.Y.

10. فوارية بلبشير : مرجع سابق ، 10 •.r.

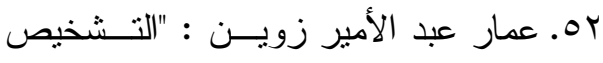

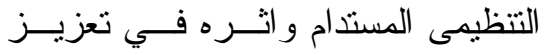

التضدين الوظيفى : در ساسة اسـتطظلاعية

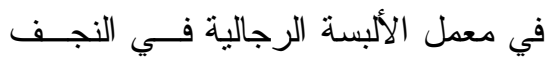

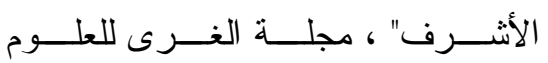

الاقتصادية والإداريـــة ، كليـــة الإدارة

و الاقتصساد ، جامعة الكوفة ، العراق ، ع

.$r \cdot 17$ ، $r q$

سor. معمر قربة : "التشخيص الاســتراتيجى

كمذل لاتخاذ القرارات الاستر اتيجية" ،

مجلة الاقتصاد و التتمية البشرية ، جامعة

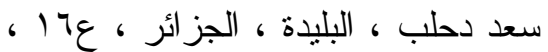
.$r \cdot I V$

54. Rahimi Hamid et al : The Analysis of Organizational Diagnosis on Based Six Boy 
83. See :

- Jingxiao Zhang et al., op.cit., pp. 2, 3.

84. Virgil-Ion Popovici, op.cit., p. 153.

85. Bilal Bin Saeed \& Wenbin Wang, op.cit., p. 425.

86. Zoya V. Yakimova, et al., : op.cit., p. 45.

$$
\text { : راجع }
$$

- فوارية بلبشير ، مرجع سابق ، ص

$$
.1 .7
$$

88. Rahimi Hamid et al., op.cit., p. 85 .

89. Deborah A. O'Neil, op.cit. p. 52.

90. Vida Korkor Tetteh, op.cit., pp. 23, 24.

19. فوارية بلبشير ، مرجـع سـابق ، ص

r9. المرجع السابق ، ص 111 ، ، 111.

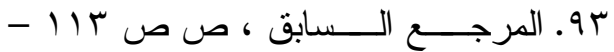
.117

94. Rahimi Hamid et al., op.cit., p. 85.

95. Deborah A. O'Neil, op.cit. p. 53 $-54$.

96. Rahimi Hamid et al., op.cit., p. 86.

97. Bilal Bin Saeed \& Wenbin Wang, op.cit., p. 426.

98. Mario Ivan Tarride, et al., Healthy Organizations : Toward a Diagnostic Method, Universidad de Santiago de Chile, Chile, pp. $8-9$,
65. Bilal Bin Saeed \& Wenbin Wang, op.cit., p. 425.

66. Virgil - Ion Popovici, op.cit., p. 151.

67. James M. Mcfillen, op.cit., p. 225.

68. Beborah A. O'Neil : op.cit., p. 51.

69. Theo J.B.M. Postma \& Robert A.W.Kok : op.cit., p. 3.

70. Bilal Bin Saeed \& Wenbin Wang, op.cit., p. 426.

l. حسن محمد أحمد مختار : إدارة التغيير

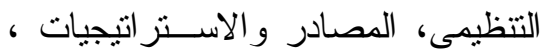

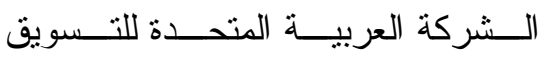

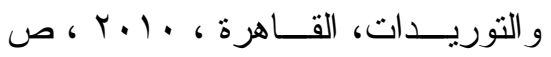
.1..

72. Coleman C.A., op.cit., p. 3.

73. Ibid, p. 7.

74. Theo J.B.M. Postma \& Robert A.W.Kok, op.cit., p. 3.

75. Rahimi Hamid, et al., op.cit., p. 85.

76. Jamis, M. Mcfillen, et al., op.cit., p. 223.

77. Vida Korkor Tetteh, op.cit.,p. 22.

78. Deborah A.O'Neil. op.cit., p. 52.

79. Vida Korkor Tetteh, op.cit., p. 23.

80. See :

- Bilal Bin Saeed \& Wenbin Wang, op.cit., p. 429.

81. Virgil-Ion Popovici, op.cit., p.153.

82. Ibid, pp. 151, 152. 
- Vida Korkor Tetteh, op.cit., p. 36.

- Rahimi Hamid et al., op.cit., p. 86.

112. Jingxiao zhang et al., opc.ti., pp. $2-4$.

113. Preziosi, R. Organizational Diagnosis Questionnaire, 22 October 2013; (EB/OL). Available at : http://9rap.org/docs/ICB/Preziosi20 \%-organ20\%-ODQ20\%.pdf.

ع

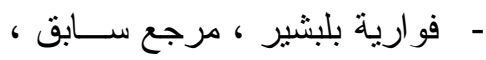

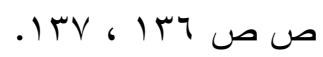

110 سابق ، ص س IV I.

116. Rahimi Hamid et al., op.cit., p. 86.

، IV V و ائل محمود القطان ، مرجع سابق ،

118. See :

$$
\text { ص מ זט. }
$$

- Jingxiao zhang et al., opc.ti., p. 17.

- Rahimi Hamid et al., op.cit., p. 86.

119. Johannsdettir, L. et al., Leadership Role and Employee Acceptance of change : Implementing Environmental Sustainability Strategies with in Nordic Insurance Companies. J. Organ. Chang. Manag, Vol. 28, 2015, pp. $72-96$. available

at

http://repositorio.uchile.cl/bistr

eam/hand\&/2250/125/89 in 16/11/2018.

99. James M., Mcfillen, op.cit., p. 223.

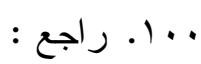

- فوارية بلبشير ، مرجع سابق ، ص

$$
\begin{aligned}
& .1 \\
& \text { 1. } 1 \text {. المرجع السابق ، ص } 9 \text { ـ 1. }
\end{aligned}
$$

102. Deborah A. O'Neil, op.cit., p. 53.

ب ا ـ فوارية بلبشير ، مرجع سـابق ، ص

ـ ـ ا. المرجع السابق ، ص VIV

105. See :

- Coleman, CA; op.cit., p. 2.

106. Josef Kusik : op.cit., p. 2.

107. See :

- Bilal Bin Saeed \& Wenbin Wang, opc.ti., p. 426.

108. Ibid.

109. See :

- Vida Korkor Tetteh, op.cit., pp. $27-40$.

- Bilal Bin Saeed \& Wenbin Wang, opc.ti., p. 427.

- Josef Kasik, op.cit., p. 3.

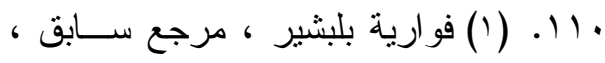
ص ص مाו.

111. See : 
المـــــرى ، القــــاهرة ، ع9919 19 ص

. Y7T

9r ا. رمضان أحمد عيد وآخرون : الإدارة

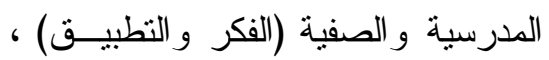

السحاب للنشر و التوزيع ، مصر الجديدة

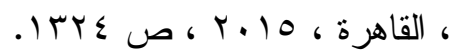

130. Croft, C. et al., The Impact of Emotionally Important Social Identity : A Challenge for Nurses in the English National Health Service. Organ. Stud. Vol. 36, 2015, pp. $113-131$.

ابا. شاكر محمد فتحى أحمد : المنظمـات

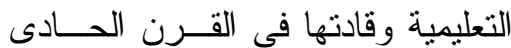

و العشرين "افتتاحية العــدد" ، مجلـــة

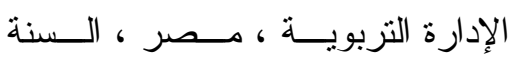

الر ابعة ، العدد الثالث عشر ، ابريــلـ الإدهل

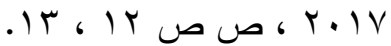

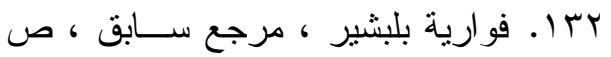

$$
\text { . }
$$

133. See :

- Jingxiao zhang et al., op.cit., p. 18.

عبا. . خــضير كــاظم حمــود : الــسلوك .

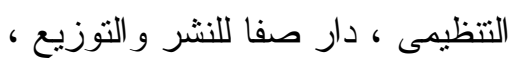

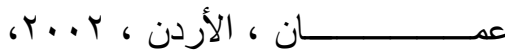

ص ص מגו.

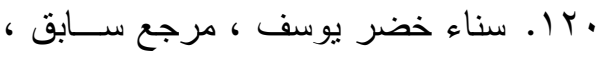

$$
\text { ص }
$$

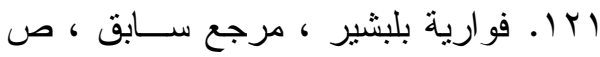

.1 ro

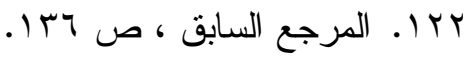

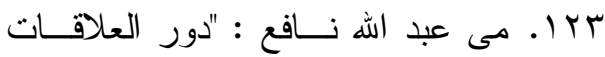

الإنسانية في تحقيق فعالية إدارة المدرسة

الثانوية العامة بسيناء ، در اسة ميدانية" ،

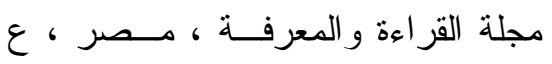

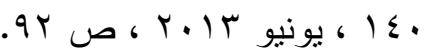

ع ا. طلعت فهمى : العلاقات الإنسانية في

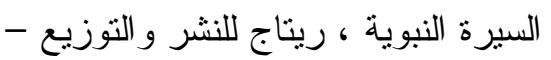

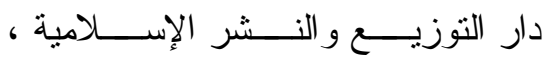

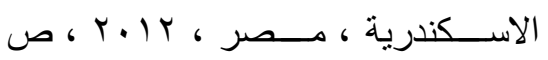

$.7 \leq$

01 ا. عمر نصير مهران رضوان ، مرجع

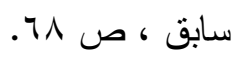

بץ ا. ـ محمد الفاتح محمود بثير المغربسى :

إدارة المـــوارد البــشرية ، دار الجنــان

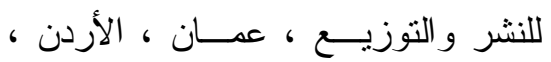

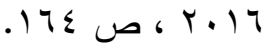

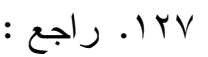

- عمر نصير مهـران رضـــوان،

مرجع سـابق ، ص ص صن

.$\wedge \varepsilon$

1Yו. أحمد زكى بدوى : معجم مصطلحات

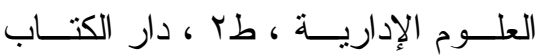




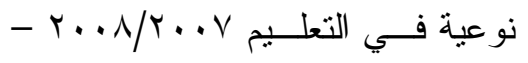
(ن

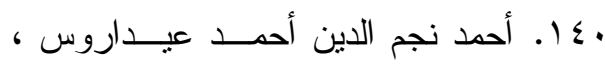

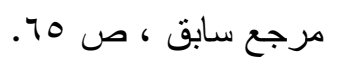

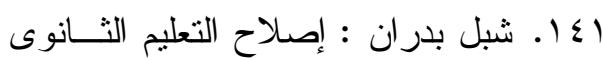
بين ضرورة المـشـاركة المجتمعيــة ومتطلبات مجتمع المعرفة - المشاركة

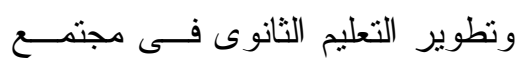

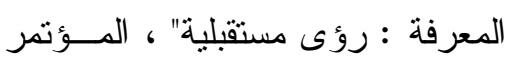
العلمى الــسنوى الــسادس المركــز القومى للبحوث التزبوية و التنمية ، في

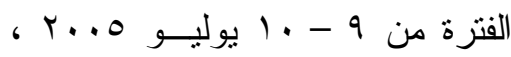

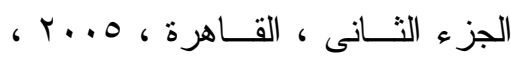
ص صـ 0 .

بـ ا. أحمد نجم الدين أحمـــد عيــداروس ،

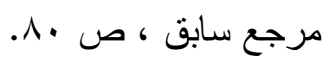

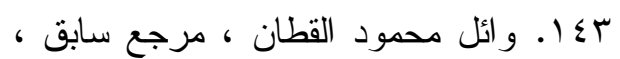

$$
\text { ص }
$$

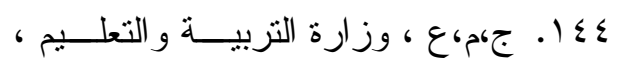

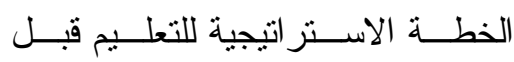

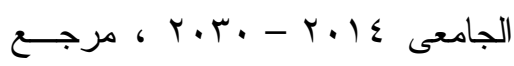

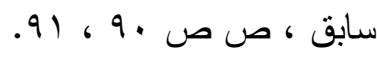

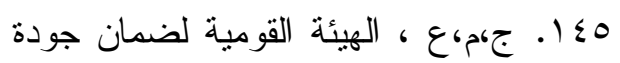

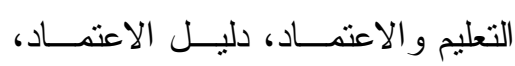

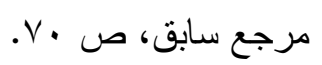

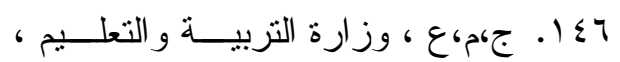

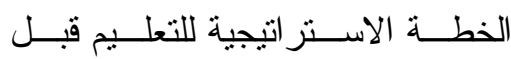

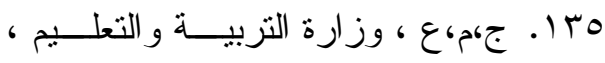

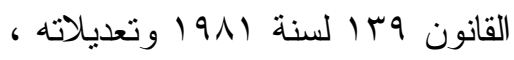

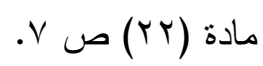

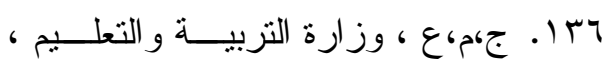

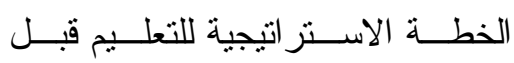

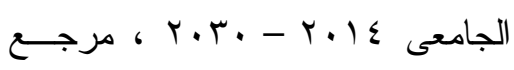

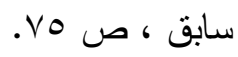

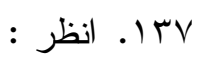

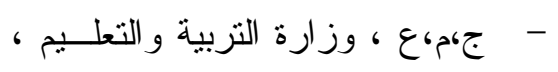

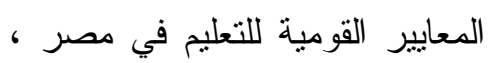

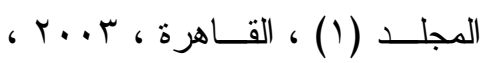
ص ص

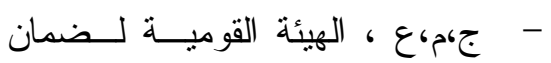

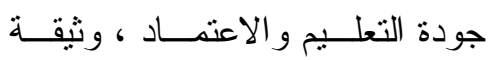

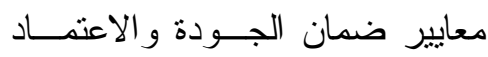

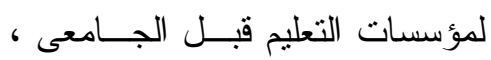

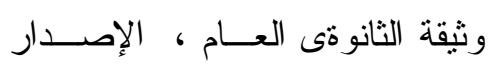

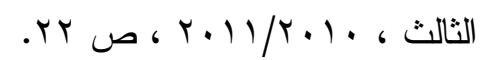
ج،م،ع ، الهيئة القوميــة لـضـمان جودة التعلــيم و الاعتمــاد ، دليـلـل

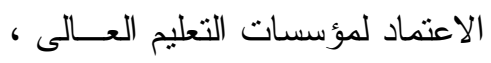
مرجع سابق ، ص ص صل 11 ، 79.

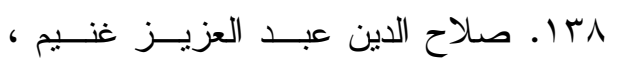

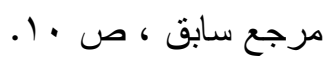

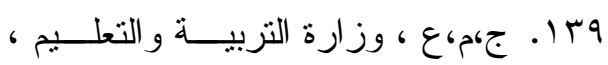
الخطة الاستر اتيجية لإصلاح التعلــيم قبل الجامعى في مصر - نحو نقلـــة 
منظومة التعليم ما قبل الجامعى فـي

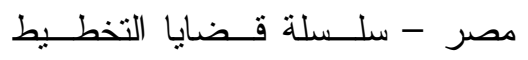

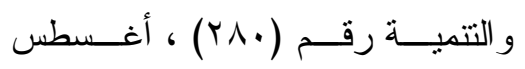
.9) r. r. T

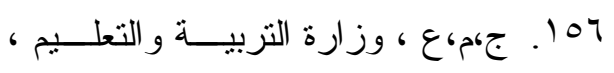

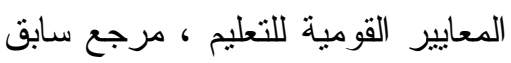

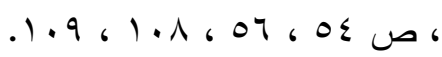
loV

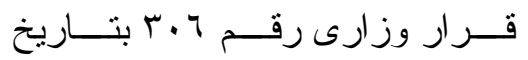

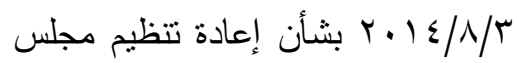

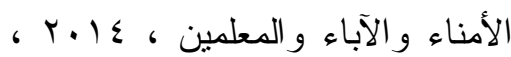

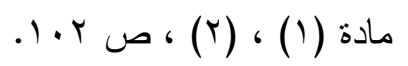

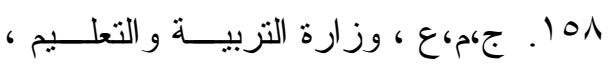
الأكاديمية المهنية للمعلمين ، برنــامج مهارات فريق العمل وحل المشكلات

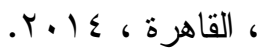

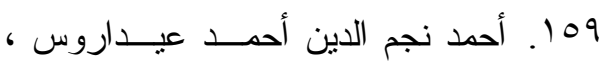

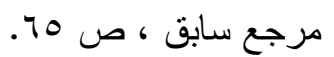

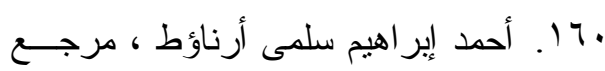

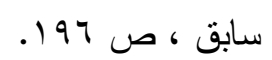

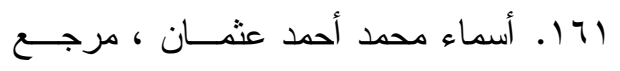

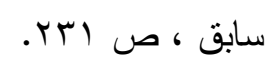

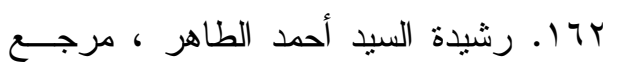

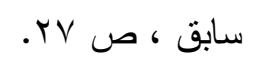

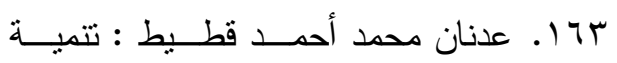
الابتكار الإدارى بالمدرســـة الثانويـــة العامة بجمهورية مصر العربية فـي لإدري بلية

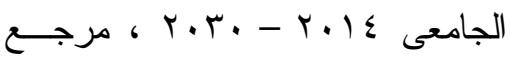
سابق ، ص ror.

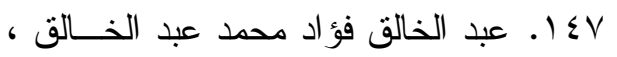

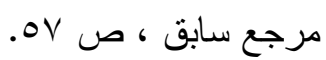

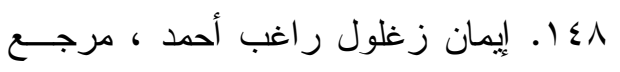

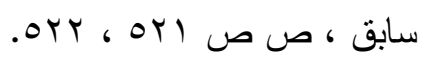

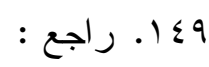

- أسماء محمد أحمد عثمان، مرجـع

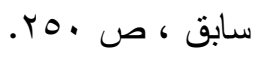
- ايمان زغلول ر اغب النجار ، مرجع ، ونان سابق ، ص ص ب Or ، O O

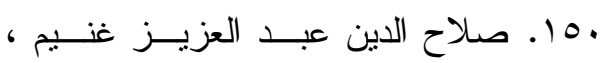
مرجع سابق ، ص س با.

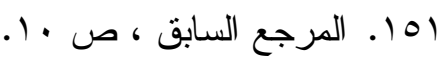

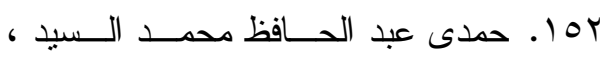

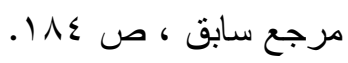

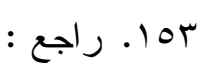
- و وائل محمود القطــان ، مرجـع

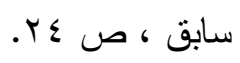
- محمد إير اهيم عبد العزيز خاطر

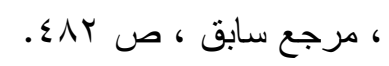

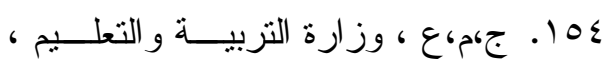

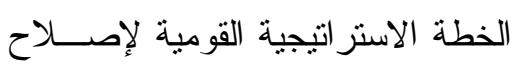

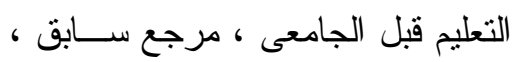

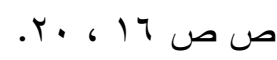

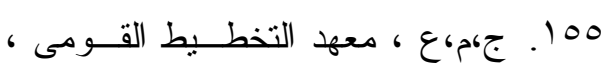

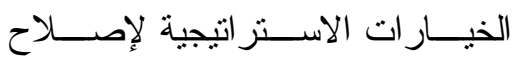




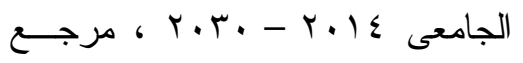

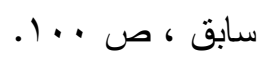

IVI I عمر نصير مهران رضوان ، مرجع

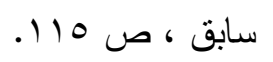

IVY ، تطوير الإدارة المدرسـية ، تثريــر

المجلس القومى للتعليم و البحث العلمى الإدى

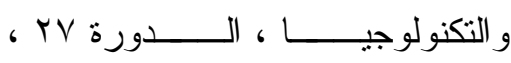
. 00 . . . . 1999

س IV . عمر نصير مهران رضوان ، مرجع سابق ، ص ص عس "1 ، 0س ا.

IV ، تقرير المجلـس القــومى للتعطــيم و البحث العلمى و التكنولوجيا ، الدورة

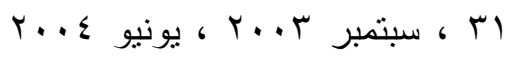

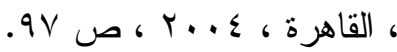

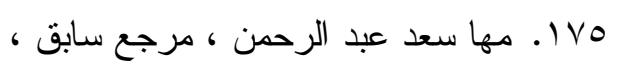

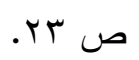

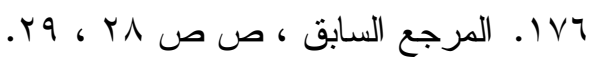

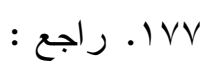

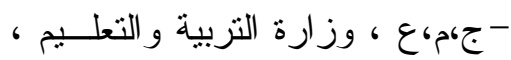

المعايير القومية للتعليم في مصر

وثيقة معايير المدرســـة الفعالـــة ،

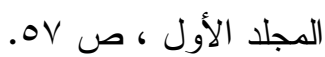

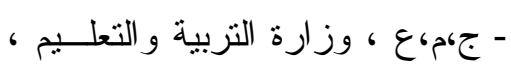

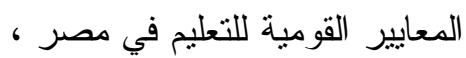
وثيقة الإدارة المتميـزة ، مرجــع
ضو ء مدخل الذكاء التتظيمى ، رسالة دكتور اه غير منشورة ، كلية التزبيــة

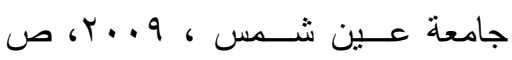
.$r \cdot \Lambda$

ـا I. إيمان زغلول ر اغب النجار ، مرجـع سابق ، ص ص س ror ، 7 1. المرجع السابق ، ص 0به.

77 ا . أسماء محمد أحمد عثمــان ، مرجـع

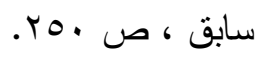

V7 ا. ج،م،ع ، القانون رقـم 100 لـسنة V. . V

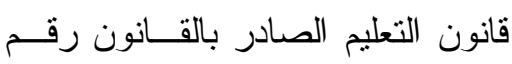
وبا لسنة /919 ولائحته التتفيذية المو اد . V ، 1 ا . ج،م،ع ، رئاسة الجمهورية ، قــرار رئيس الجمهورية بالقانون رقـم بهو

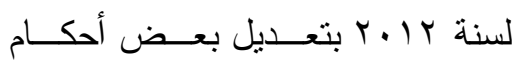

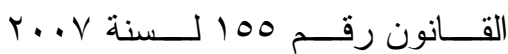
الصادر بتعديل القانون رقم

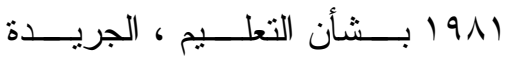
الرســمية ، العــدد عـ مكــرر ، 7

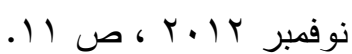
79 1. عمر نصير مهران رضوان ، مرجع سابق ، ص ص 1. 1 - 11 .

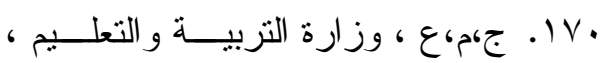

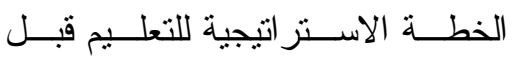




$$
\begin{aligned}
& \text { £1 ا. عزة أحمد محمد الحـسينى ، مرجـع }
\end{aligned}
$$

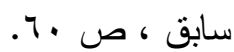

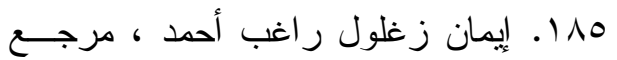

$$
\begin{aligned}
& \text { سابق ، ص ص ror } \\
& \text { 111. أحمد نجم الدين أحمــــ عيــداروس : } \\
& \text { "التمهين القيادى لمــديرى المـــدارس "ارس } \\
& \text { كمدخل لتحقيق الفعاليــة المؤســسية"، } \\
& \text { مجلة كلية التزبية بالزقازيق ، العــدد }
\end{aligned}
$$

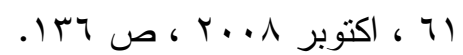

INV للقيادات الإدارية النسائية بالمـــدارس الثانوية العامة في مصر وبعض الدول الأخــرى ، رســـالة دكتـــور اه غيــر منشورة ، كلية التربية جامعــة عــين

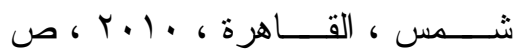

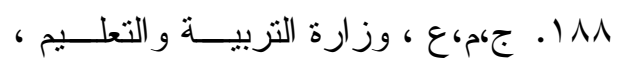

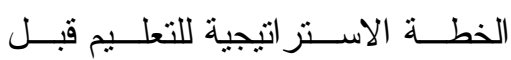

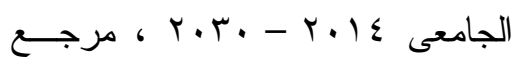

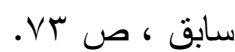

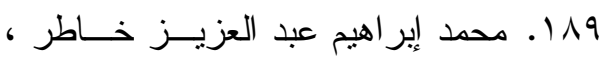
مرجع سابق ، ص ص ص 7017 ، 017.

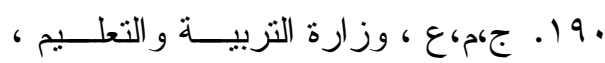

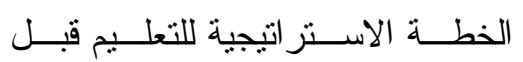

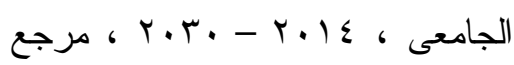
سابق ، ص V ع .

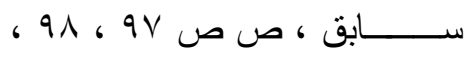
$.1 \cdot r$ IVA

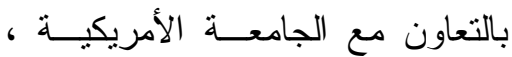
المحتوى العلمــى لبرنـــامج تــدريب

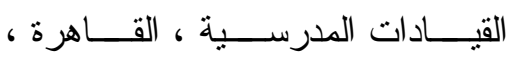
$. r \ldots r / r \ldots r$

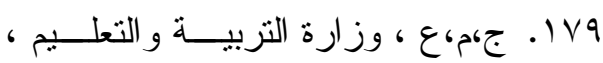

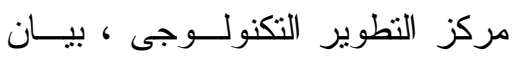
بالبر امج التى قدمت للقيادات التعليمية ونفذت من خـــلال الــشبكة القوميـــة للتعليم عن بعد منذ عام ^ ... بم.

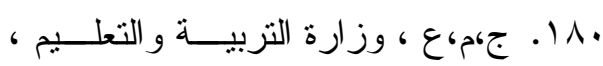
وحدة التخطيط و المتابعة ، مسـشروع تحسين التعليم الثانوى : الاتجاهــات المعاصرة في إدارة المدرسة الثانويـــة

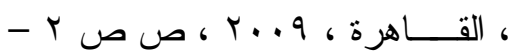
$.11 Y$

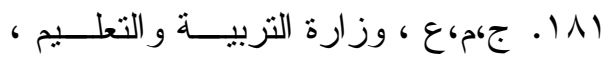
الأكاديمية المهنية للمعلمين ، برنــامج دعم التعليم - مهار ات القيادة لمديرى

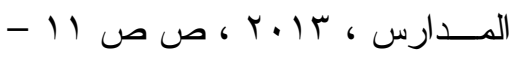
.79

Y 1 . أحمد نجم الدين أحمــد عيــداروس ،

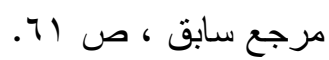

سر ا. أثنواق عبد الجليل على ، مرجع سابق ك، 
I.Y. أحمد نجم الدين أحمــد عيــداروس ،

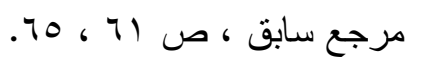$$
\text { r.r. المرجع السابق ، ص } 79 .
$$

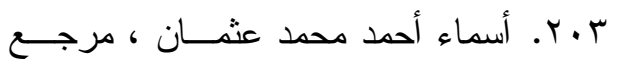

سابق ، ص ص ع ז r ، هrr.

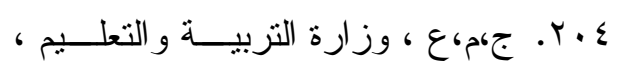

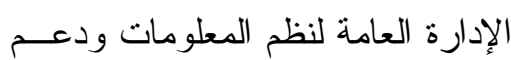

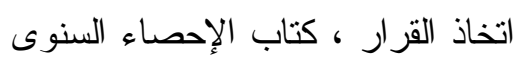

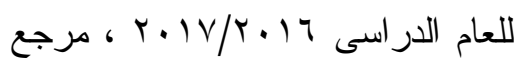

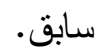

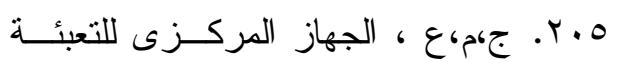

العامة و الإحصاء ، مصر في أرقـام

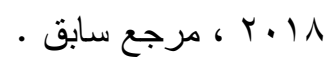

T.r.

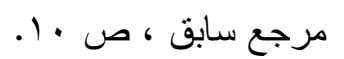

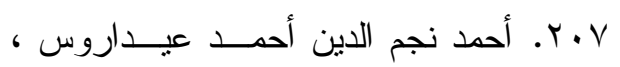

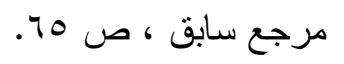

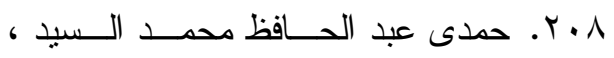

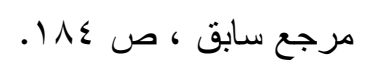

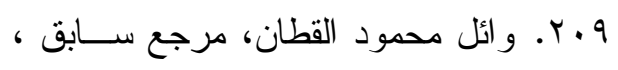

$$
\text { ص ص }
$$

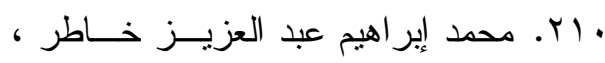

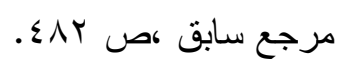

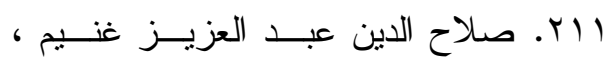

$$
\text { مرجع سابق ، ص س باح. }
$$

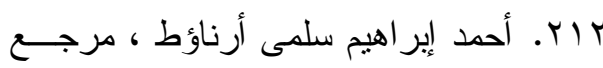

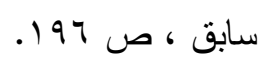

191 ـ أحمد عبد الفتاح الزكى ، وحيد شــاه

بورحماد : "القيادة الموزعة : أسـسـها لئهاه

ومنطلبات تطبيقها في مدارس التعليم

العام بمصر ، در اسة ميدانية" ، مجلة

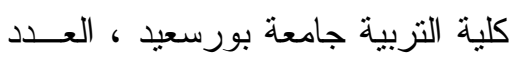

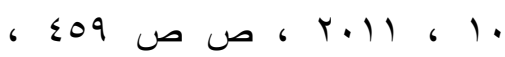

. $า$.

19 1. أسماء أحمد محمد عثــان ، مرجـع سابق ، ص . TO T.

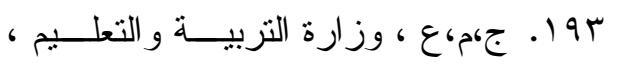

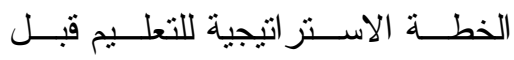

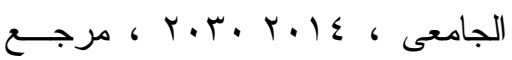

سابق ، ص ع 9.

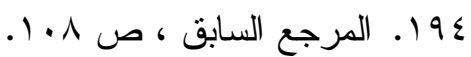

190 . المرجع السابق ، ص 978

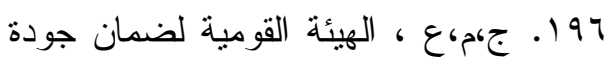

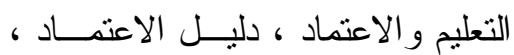

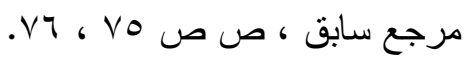

19V

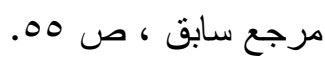

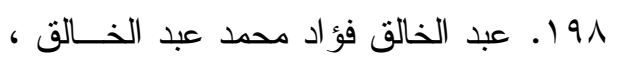

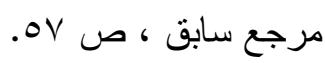
199

- محمد إبراهيم عبد العزيز خاطر

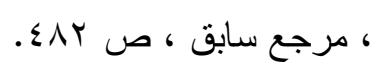

· . . . . . . .

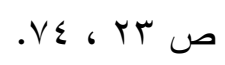




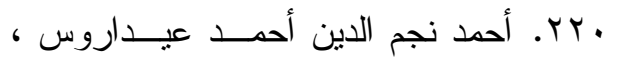

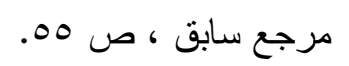

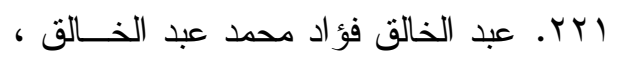

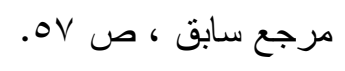

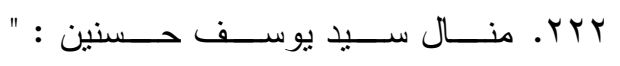
سيناريو هات مستقبلية لاختيار صانعي

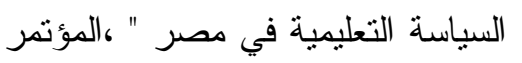
العلمي السنوي الــسادس و العـشرين للجمعية المصرية للتربيـــة المقارنـــة و الادارة التعليمية : تطــــير التعلــيم

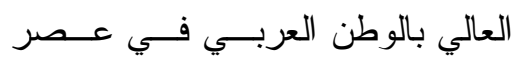

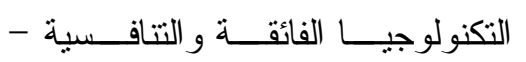

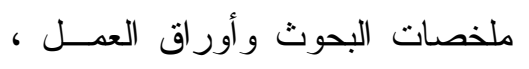
. rا r. إيمان زغلول ر اغب النجار ، مرجـع

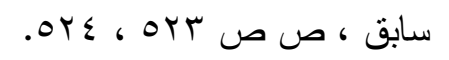

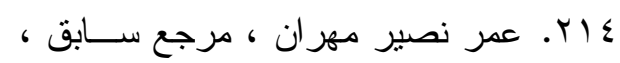

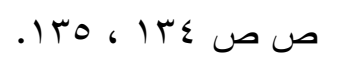

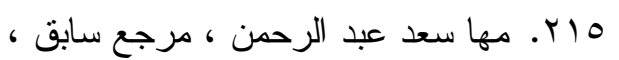

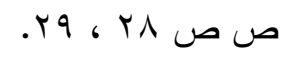

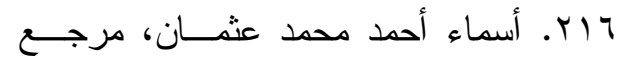
سابق ، ص .ro. rIV

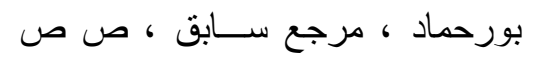

$$
\text { . } \leqslant 7 . \text { ، ، } \leqslant 9
$$

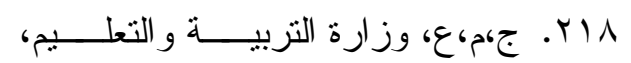

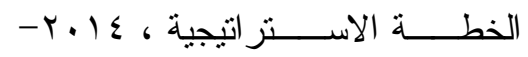

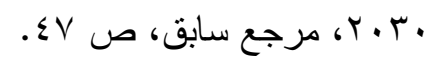

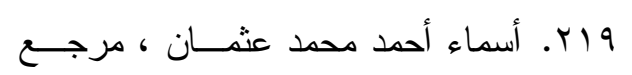

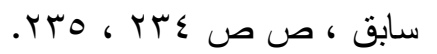

